\title{
EA
}

\section{WORLD NUCLEAR OUTLOOK}

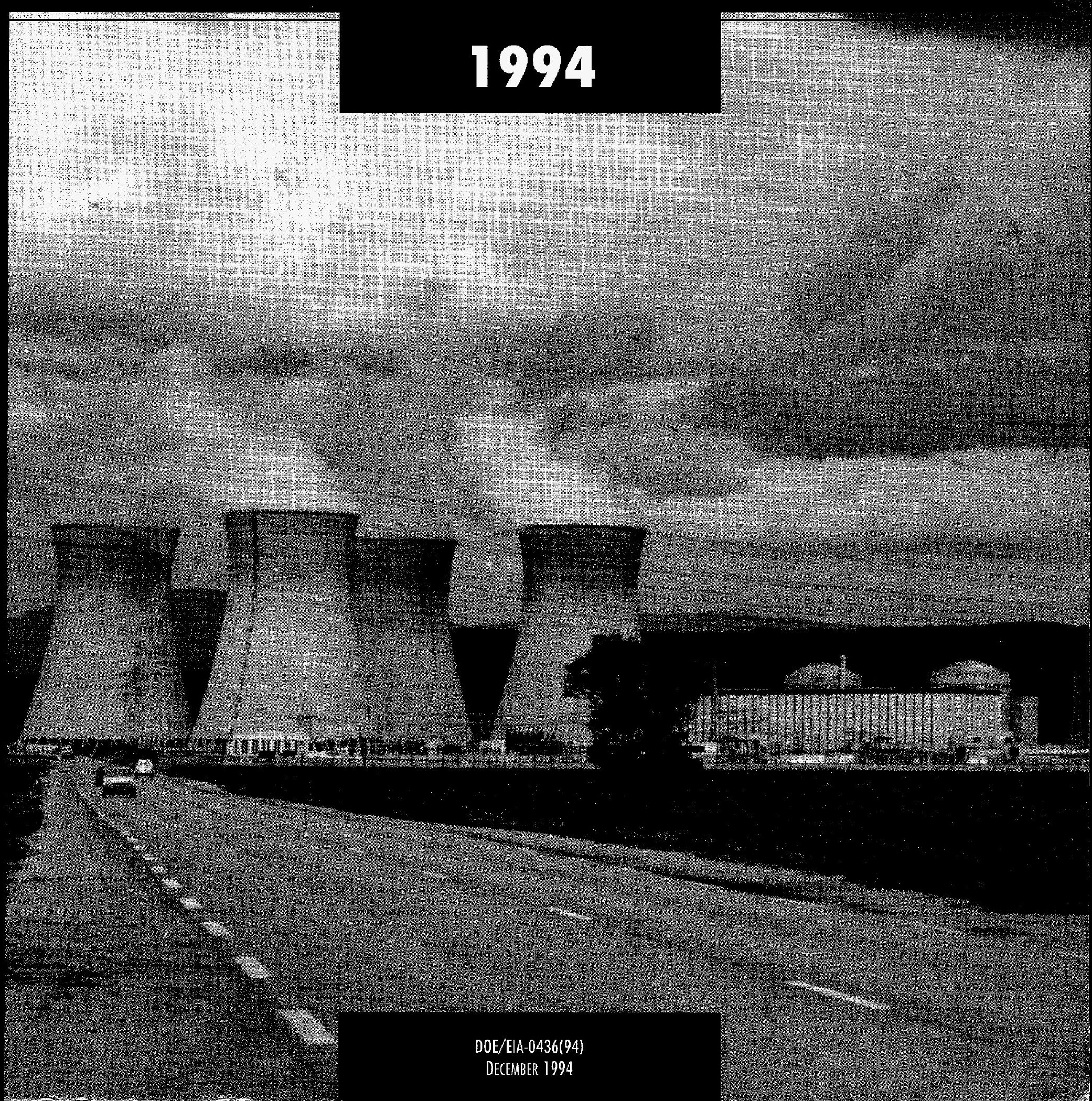


This publication and other Energy Information Administration (EIA) publications may be purchased from the Superintendent of Documents, U.S. Government Printing Office.

Telephone orders may be directed to:

Superintendent of Documents

U.S. Government Printing Office

Main Order Desk

(202) 512-1800

FAX: (202) 512-2250

8 a.m. to $4: 30$ p.m., eastern time, M-F

\title{
All mail orders should be directed to:
}

\author{
U.S. Government Printing Office \\ P.O. Box 371954 \\ Pittsburgh, PA 15250-7954
}

Complimentary subscriptions and single issues are available to certain groups of subscribers, such as public and academic libraries, Federal, State, local and foreign governments, EIA survey respondents, and the media. For further information and for answers to questions on energy statistics, please contact EIA's National Energy Information Center. Address, telephone numbers, and hours are as follows:

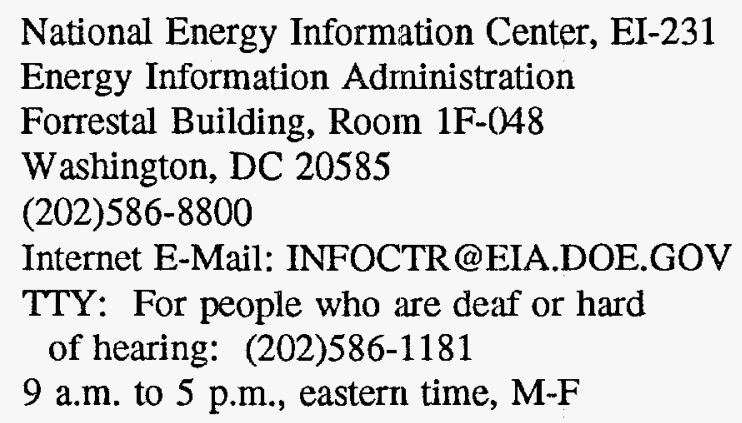

\section{Cover Photo}

The Bugey plant has five operating units with a combined capacity of 4.2 net gigawatts.

Photo Credit Appendix C: TU Services, Comanche Peak 
DOE/EIA-0436(94)

Distribution Category UC-950

\title{
World Nuclear Outlook 1994
}

\author{
December 1994
}

Contains information on commercial nuclear capacity, fuel requirements, spent fuel and the uranium market.

\section{Energy Information Administration}

Office of Coal, Nuclear, Electric and Alternate Fuels

U.S. Department of Energy

Washington, DC 20585

This report was prepared by the Energy Information Administration, the independent statistical and analytical agency within the Department of Energy. The information contained herein should not be construed as advocating or reflecting any policy position of the Department of Energy or of any other organization. 


\section{Contacts}

This report was prepared in the Office of Coal, Nuclear, Electric and Alternate Fuels by the Analysis and Systems Division. General information regarding this publication may be obtained from John Geidl (202/2545570), Director, Office of Coal, Nuclear, Electric and Alternate Fuels; Robert M. Schnapp (202/254-5392), Director, Analysis and Systems Division; Betsy O'Brien (202/254-5490), Chief of the Supply Analysis Branch; or Dr. Z.D. Nikodem (202/254-5550), Chief of the Energy Resources Assessment Branch. Detailed technical ques- tions should be referred to William Liggett (202/2545508), project manager; Ercan Tukenmez (202/254-5544), uranium market model forecasts and operation; Diane Jackson (202/254-5536), International Nuclear Model forecasts; S. Victoria Krusiewski (202/254-5538), uranium marketing activities; Kenneth Chuck Wade (202/254-5514), nuclear capacity status and projections; or Michelle Bowles (202/254-5378), nuclear capacity status and projections. 


\section{DISCLAIMER}

This report was prepared as an account of work sponsored by an agency of the linited States Government. Neither the United States Government nor any agency thereof, nor any of their employees, make any warranty, express or implied, or ascumes any legal liability or responsibility for the accuracy, completeness, or usefulness of any information, apparatus, product, or process disclosed, or represents that its use would not infringe privately owned rights. Reference herein to any specific commercial product, process, or service by trade name, trademark, manufacturer, or otherwise does not necessarily constitute or imply its endorsement, recommendation, or favoring by the United States Government or any agency thereof. The views and opinions of authors expressed herein do not necessarily state or reflect those of the United States Government or any agency thereof. 


\section{DISCLAIMER}

Portions of this document may be illegible electronic image products. Images are produced from the best available original document. 


\section{Preface}

Section 205(a)(2) of the Department of Energy Organization Act of 1977 (Public Law 95-91) requires the Administrator of the Energy Information Administration (EIA) to carry out a central, comprehensive, and unified energy data information program that will collect, evaluate, assemble, analyze, and disseminate data and information relevant to energy resources, reserves, production, demand, technology, and related economic and statistical information.

As part of the EIA program to provide energy information, this analysis report presents the current status and projections through 2010 of nuclear capacity, generation, and fuel cycle requirements for all countries in the world using nuclear power to generate electricity for commercial use. It also contains information and forecasts of developments in the uranium market. Long-term projections of U.S. nuclear capacity, generation, and spent fuel discharges for three different scenarios through 2040 are developed for the Department of Energy's Office of Civilian Radioactive Waste Management (OCRWM). In turn, the OCRWM provides partial funding for preparation of this report. The projections of uranium requirements are provided to the Organization for Economic Cooperation and Development (OECD) for preparation of the Nuclear Energy Agency/OECD report, Summary of Nuclear Power and Fuel Cycle Data in OECD Member Countries.
Long-term nuclear capacity projections used for the High Case scenario were obtained from the Office of Integrated Analysis and Forecasting, Energy Information Administration. Some of these projections were developed using the World Integrated Nuclear Evaluation System (WINES) model. The model is documented in Model Documentation of the World Integrated Nuclear Evaluation System, Volumes I, II, and III (DOE/EIM049). The International Nuclear Model PC version (PCINM) used for calculating the electricity generation values and fuel cycle requirements in this report, is documented in the International Nuclear Model Personal Computer Model Documentation. The Uranium Market Model (UMM) was used to project uranium prices, production, imports and inventories. Its documentation can be found in Model Documentation of the Uranium Market Model (prepared by the Oak Ridge National Laboratory).

The legislation that created the EIA vested the organization with an element of statutory independence. The EIA does not take positions on policy questions. Its responsibility is to provide timely, high-quality information and to perform objective, credible analyses in support of deliberations by both public and private decisionmakers. Accordingly, this report does not purport to represent the policy positions of the U.S. Department of Energy or the Administration.

This report was formerly published as "World Nuclear Capacity and Fuel Cycle Requirements." 


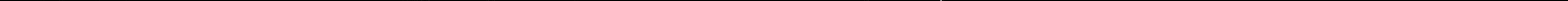




\section{Contents}

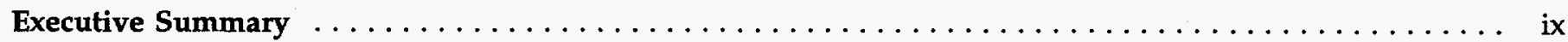

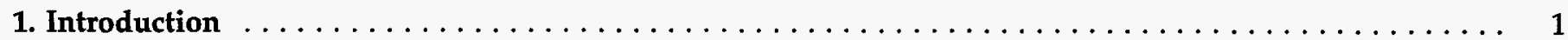

2. Nuclear Capacity Status and Projections $\ldots \ldots \ldots \ldots \ldots \ldots \ldots \ldots \ldots \ldots \ldots \ldots \ldots \ldots$

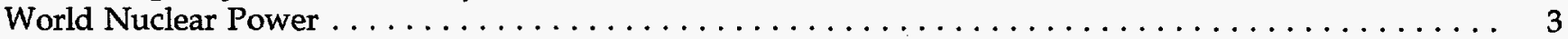

Regional Developments and Projections $\ldots \ldots \ldots \ldots \ldots \ldots \ldots \ldots \ldots \ldots \ldots \ldots \ldots \ldots \ldots$

3. Nuclear Fuel Cycle and Uranium Market Developments $\ldots \ldots \ldots \ldots \ldots \ldots \ldots \ldots \ldots \ldots \ldots \ldots \ldots \ldots$

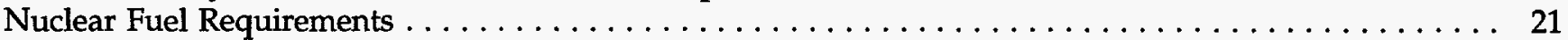

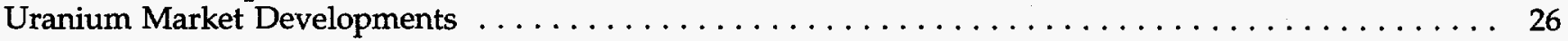

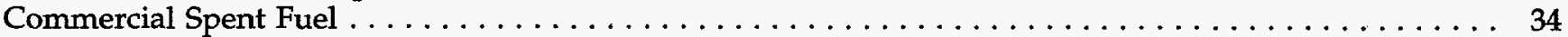

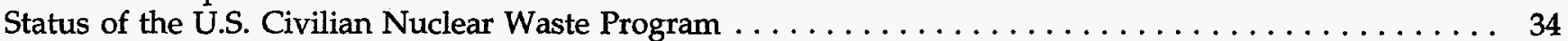

4. Operating and Maintenance Costs for Nuclear Power Plants in the United States . . . . . . . . . . 39

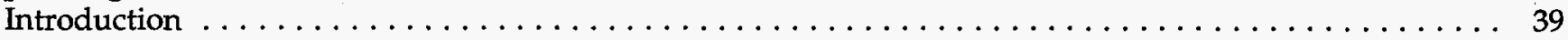

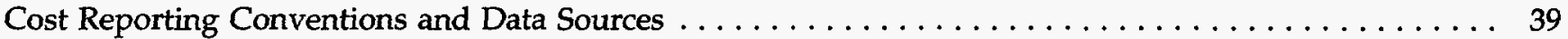

Trends and Variations in Nuclear O\&M Costs $\ldots \ldots \ldots \ldots \ldots \ldots \ldots \ldots \ldots \ldots \ldots \ldots \ldots \ldots \ldots$

Reasons for Increases in $O \& M$ Costs $\ldots \ldots \ldots \ldots \ldots \ldots \ldots \ldots \ldots \ldots \ldots \ldots \ldots \ldots \ldots \ldots \ldots \ldots$

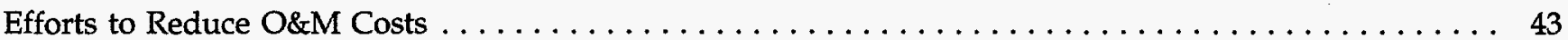

Statistical Analysis of O\&M Costs for U.S. Nuclear Power Plants $\ldots \ldots \ldots \ldots \ldots \ldots \ldots \ldots \ldots \ldots \ldots 45$

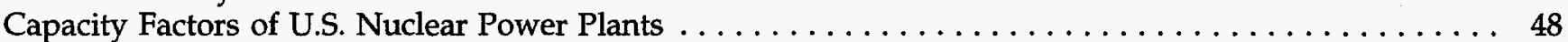

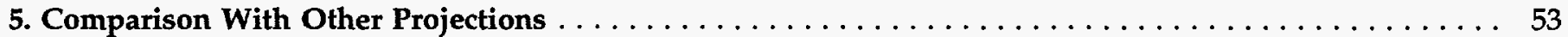

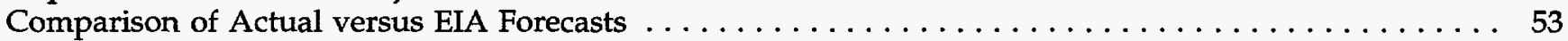

Comparison With Last Year's EIA Report $\ldots \ldots \ldots \ldots \ldots \ldots \ldots \ldots \ldots \ldots \ldots \ldots \ldots \ldots \ldots \ldots \ldots$

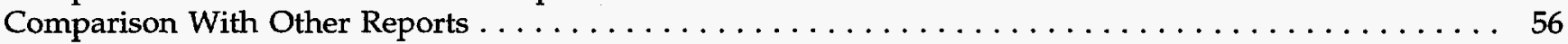

Comparison to Energy Resources International $\ldots \ldots \ldots \ldots \ldots \ldots \ldots \ldots \ldots \ldots \ldots \ldots \ldots \ldots$

Comparison to Uranium Institute $\ldots \ldots \ldots \ldots \ldots \ldots \ldots \ldots \ldots \ldots \ldots \ldots \ldots \ldots \ldots \ldots \ldots$

Comparison to Nuclear Assurance Corporation $\ldots \ldots \ldots \ldots \ldots \ldots \ldots \ldots \ldots \ldots \ldots \ldots \ldots \ldots$

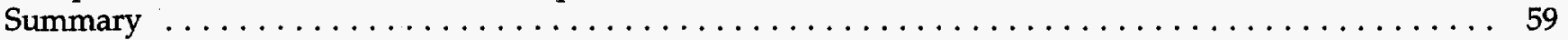

Appendices

A. Nuclear Power Technology and the Nuclear Fuel Cycle $\ldots \ldots \ldots \ldots \ldots \ldots \ldots \ldots \ldots \ldots \ldots \ldots$

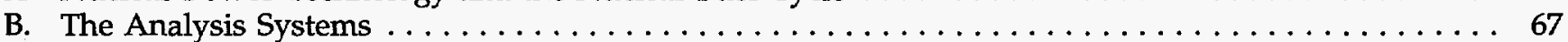

C. World Nuclear Units Operable as of December $31,1993 \ldots \ldots \ldots \ldots \ldots \ldots \ldots \ldots \ldots \ldots \ldots \ldots$.

D. World Nuclear Generating Units in the Construction Pipeline as of December 31, $1993 \ldots \ldots$. . . . 97

E. Long-Term Projections of Capacity, Generation, and Spent Fuel in the United States,

1994 Through 2040 . . . . . . . . . . . . . . . . . . . . . . . . . . . . . . . . . . . . . 103

F. World Nuclear Fuel Cycle Facilities That Prepare Fuel for Nuclear Power Plants . . . . . . . . 109

G. Uncertainties in the U.S. Uranium Market $\ldots \ldots \ldots \ldots \ldots \ldots \ldots \ldots \ldots \ldots \ldots \ldots \ldots \ldots \ldots$

H. U.S. Customary Units of Measurement, International System of Units (SI), and Selected Data Tables

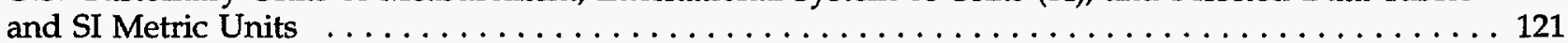

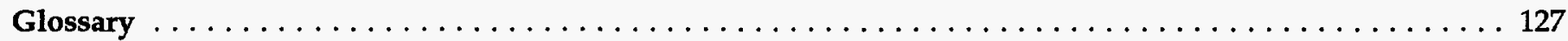


1. Operable Nuclear Power Plant Statistics, 1992 and 1993

2. Status of Commercial Nuclear Generating Units in the Construction Pipeline as of

December 31, 1993

3. 1993 Operable Nuclear Capacities and Projected Capacities for $1995,2000,2005$ and $2010 \ldots \ldots \ldots$

4. US. Nuclear Capacity and Generation as of December 31, 1993, by Federal Region $2010 \ldots \ldots \ldots \ldots$

4. U.S. Nuclear Capacity and Generation as of December 31, 1993, by Federal Region . . . . . . . . . . . .

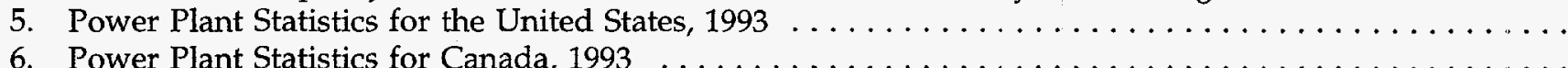

7. Power Plant Statistics for the Western Europe Region, $1993 \ldots \ldots \ldots \ldots \ldots \ldots \ldots \ldots \ldots \ldots \ldots \ldots$

8. Power Plant Statistics for the Eastern Europe Region, $1993 \ldots \ldots \ldots \ldots \ldots \ldots \ldots \ldots \ldots \ldots \ldots \ldots \ldots \ldots 14$

9. Power Plant Statistics for the Far East Region, $1993 \ldots \ldots \ldots \ldots \ldots \ldots \ldots \ldots \ldots \ldots \ldots \ldots \ldots \ldots \ldots$

10. Power Plant Statistics for the Other Region, $1993 \ldots \ldots \ldots \ldots \ldots \ldots \ldots \ldots \ldots \ldots \ldots \ldots \ldots \ldots$

11. Projected Cumulative Uranium Requirements for World Nuclear Power Plants, 1994-2010 . . . . . . . 22

12. Projected Annual Uranium Requirements for World Nuclear Power Plants, 1994-2010 . . . . . . . . . . 23

13. Projected Annual Uranium Requirements for Western Europe and the Far East With and Without MOX Fuel, Low Case, 1994-2010 . . . . . . . . . . . . . . . . . . . . . . . . . . . . . . . 24

14. Projected Cumulative Enrichment Service Requirements for World Nuclear Power Plants, 1994-2010 . . .

15. Projected Annual Enrichment Service Requirements for World Nuclear Power Plants, 1994-2010 . . . . .

16. Projected Annual Enrichment Requirements for Western Europe and the Far East With and Without

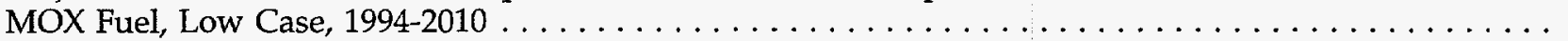

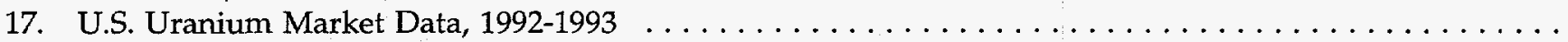

18. Projected U.S. Spot-Market Prices for Uranium Under Current Market Conditions, 1994-2005 . . . . . . . 30

19. Projected U.S. Uranium Requirements, Net Imports, Commercial Inventories, and Production of

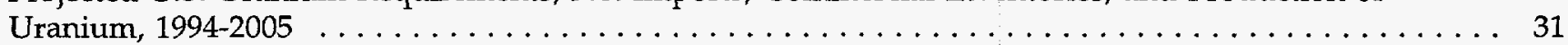

20. Foreign Production Capability at $\$ 30$ per Pound $\mathrm{U}_{3} \mathrm{O}_{8} \ldots \ldots \ldots \ldots \ldots \ldots \ldots \ldots \ldots \ldots$

21. Projected Cumulative Discharges of Spent Fuel for World Nuclear Power Plants, 1994-2010 . . . . . . .

22. Projected Annual Discharges of Spent Fuel for World Nuclear Power Plants, 1994-2010 . . . . . . . . .

23. Comparison of Average U.S. O\&M Costs by Age and Plant Size, 1990-1992 . . . . . . . . . . . . . . .

24. U.S. Nuclear-Generating Units Achieving the Best Performance Records as of December 31, 1993 . . .

25. Number and Percent of U.S. Nuclear Units at Different Capacity Factor Levels by Age Group, 1991 to 1993 . . . . . . . . . . . . . . . . . . . . . . . . . . . . . . . . . . . . . . . . . . . 50

26. Historical Capacity Factors for World Nuclear Power Plants, 1980 to 1993 . . . . . . . . . . . . . . .

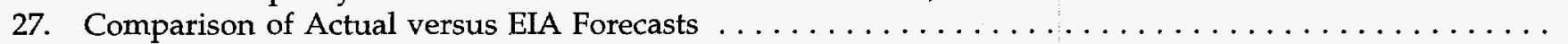

28. Comparison of Projections for U.S. Nuclear Capacity at Year End, 1995, 2000 and 2005 . . . . . . . . .

29. Comparison of Selected Forecasts of Fuel Cycle Requirements for the United States, 1994 Through 2005

30. Comparison of Projections of Foreign Nuclear Capacity at Year End, 1995, 2000, and 2005 . . . . . . . .

31. Comparison of Selected Forecasts of Fuel Cycle Requirements for Foreign Countries, 1994 Through 2005

B1. WINES Economic Parameter Values Assumptions for the High Case $\ldots \ldots \ldots \ldots \ldots \ldots \ldots$

B2. WINES Energy Assumptions for the High Case $\ldots \ldots \ldots \ldots \ldots \ldots \ldots \ldots \ldots \ldots \ldots \ldots \ldots$

B3. WINES Electrical and Nuclear Share Parameter Values Assumed for the High Case $\ldots \ldots \ldots \ldots \ldots$

B4. Results of the Regression Analysis of the Enrichment Assay Equations $\ldots \ldots \ldots \ldots \ldots \ldots \ldots \ldots$

B5. Results of the Regression Coefficient Tests $\ldots \ldots \ldots \ldots \ldots \ldots \ldots \ldots \ldots \ldots \ldots \ldots \ldots \ldots \ldots \ldots$

B6. Domestic Fuel Management Plans for Extended Burnup Scenarios $\ldots \ldots \ldots \ldots \ldots \ldots \ldots \ldots \ldots \ldots 75$

B7. Foreign Fuel Management Plans for Extended Burnup Scenarios $\ldots \ldots \ldots \ldots \ldots \ldots \ldots \ldots \ldots \ldots$

C1. Roster of Nuclear Generating Units Operable as of December $31,1993 \ldots \ldots \ldots \ldots \ldots \ldots \ldots$

C2. Key to Utility Codes for Rosters of Nuclear Generating and Construction Pipeline Units . . . . . . . . 93

C3. Key to Reactor Supplier Codes for Rosters of Nuclear Generating and Construction Pipeline Units ... 96

D1. Roster of Nuclear Units in the Construction Pipeline as of December 31, $1993 \ldots \ldots \ldots \ldots \ldots$. . . . . . 99

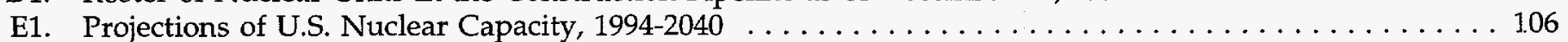

E2. Projections of U.S. Nuclear Electricity Generation, $1994-2040 \ldots \ldots \ldots \ldots \ldots \ldots \ldots \ldots$

E3. Projections of U.S. Cumulative Spent Fuel Discharges Through $2040 \ldots \ldots \ldots \ldots \ldots \ldots \ldots$

F1. World Nuclear Fuel Cycle Facilities That Prepare Fuel for Nuclear Power Plants . . . . . . . . . . 111

G1. Annual Russian-Origin Uranium Sales Authorized by the Amendment, 1994-2003 . . . . . . . . . . 1.17

H1. Projected Annual Uranium Requirements for World Nuclear Power Plants, 1994-2010 . . . . . . . . . 1.24 


\section{Tables (Continued)}

H2. Projected Cumulative Uranium Requirements for World Nuclear Power Plants, 1994-2010 . . . . . . . 124

H3. Projected U.S. Spot-Market Prices for Uranium Under Current Market Conditions, 1994-2005 . . . . . 125

H4. Projected U.S. Uranium Requirements, Net Imports, Commercial Inventories, and Production of

Uranium, $1994-2005$. . . . . . . . . . . . . . . . . . . . . . . . . . . . . . . . . . . . . . . . 125

\section{Figures}

ES1. Percent Net U.S. Utility Electricity Generation by Fuel Type, $1993 \ldots \ldots \ldots \ldots \ldots \ldots \ldots \ldots$. . . . . . ix

ES2. 1993 World Nuclear Capacity and Projected Capacity for $2010 \ldots \ldots \ldots \ldots \ldots \ldots \ldots \ldots \ldots \ldots$

1. Nations With the Largest Nuclear Generating Capacity, $1993 \ldots \ldots \ldots \ldots \ldots \ldots \ldots \ldots \ldots \ldots \ldots$

2. Total Uranium Requirements by Region, 1994-2010, Low Case Projections . . . . . . . . . . . . 23

3. Total Enrichment Requirements by Region, 1994-2010, Low Case Projections . . . . . . . . . . . . 26

4. Total Spent Fuel Discharges by Region, 1994-2010, Low Case Projections . . . . . . . . . . . . . 36

5. Projections of U.S. Utility Spent Fuel Exceeding Wet Pool Storage Capacity Through 2010 . . . . . . . . 37

6. Projected Number of U.S. Reactor Sites Needing Additional Storage Capacity Through 2010 . . . . . . 38

7. Comparison of Average Operating and Maintenance Costs for U.S. Nuclear and Coal-Fired

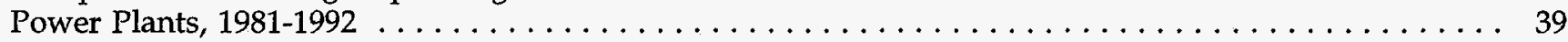

8. Average Operating and Maintenance Costs for U.S. Nuclear Power Plants, 1981-1992 . . . . . . . . . . 40

9. Average Operating and Maintenance Costs per Megawatt-electric of U.S. Nuclear Capacity, 1981-1992 . 41

10. Variation in Operating and Maintenance Costs for U.S. Nuclear Power Plants, 1990-1992 . . . . . . . . . 41

11. Staff Size per Megawatt of U.S. Nuclear Plant Capacity, 1981-1992 . . . . . . . . . . . . . . . . . 42

12. Annual Outage Rates of the U.S. Nuclear Industry, $1981-1992 \ldots \ldots \ldots \ldots \ldots \ldots \ldots \ldots \ldots \ldots \ldots . \ldots 2$

13. Cumulative Percentage of U.S. Nuclear Plants at Different Cost Levels, by 3-Year Groups,

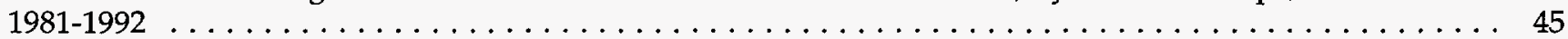

14. Cumulative Percentage of U.S. Nuclear Plants at Different Cost Levels, by Plant Size, 1990-1992 . . . . 46

15. Cumulative Percentage of U.S. Nuclear Plants at Different Cost Levels, by Age Group, 1990-1992 . . . . 46

16. Operating and Maintenance Costs of U.S. Nuclear Power Plants, by Age and Size Groups, 1981-1992 .. 48

17. U.S. Nuclear Power Plant Average Capacity Factors, $1975-1993$. . . . . . . . . . . . . . . . . . . . 48

18. U.S. Nuclear Capacity Factors by Reactor Size, $1991-1993 \ldots \ldots \ldots \ldots \ldots \ldots \ldots \ldots \ldots \ldots \ldots \ldots \ldots$

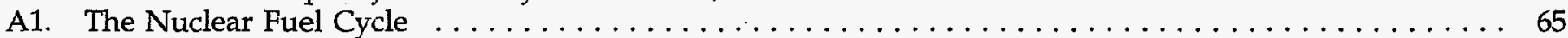

E1. Projections of U.S. Nuclear Capacity, $1994-2030 \ldots \ldots \ldots \ldots \ldots \ldots \ldots \ldots \ldots$

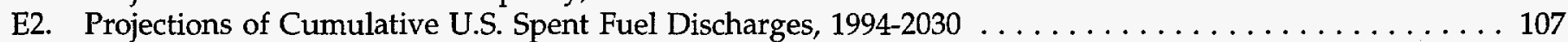





\section{Executive Summary}

\section{Worldwide Status of Nuclear Power}

As we approach the 21st century, the future of commercial nuclear power remains uncertain throughout most of the world. The uncertainty is largely attributable to public concerns about nuclear safety which have led to extensive and costly safeguards. What was expected to be a cheap source of electricity nearly 20 years ago, has become more costly.

The current state of the industry is that, as of December 31, 1993, there were 430 nuclear reactors operating throughout the world. During the year, nine units were connected to the electrical grid, while three were retired. Japan led all countries with four nuclear units starting operation, whereas Canada, China, France, Russia and the United States each had one unit added to the list of operable units.

The 430 reactors spread throughout 30 countries had a total capacity of 338.1 net gigawatts-electric (GWe), accounting for over one-quarter of the electricity generation within the countries. Nuclear-generated electricity was 2,093 net terawatthours (TWh), a 3.3percent increase over the 2,027 TWh in $1992 .{ }^{1,2} \mathrm{~A}$ total of 610 TWh of electricity was produced from 109 units in the United States, a decrease of 9 TWh from the record 1992 generation of 619 . The 610 TWh accounted for 21 percent of the electricity produced by utilities in the United States (Figure ES1).

As of December 31, 1993, 94 reactors were under construction, with a total capacity of $81.2 \mathrm{GWe}$. The majority, however, were less than 26 percent complete (52 out of 94). The countries with major nuclear power programs continued with their nuclear commitment while other countries continued at a slower pace or stopped further expansion. The United States in particular, as well as most of the Western European countries, has few, if any, plants in the construction pipeline. Conversely, Japan's nuclear construction program far surpasses that of any other country in the world with 19 units under construction, totaling 20.1 GWe of capacity. France, India, and South Korea, which are also considered to have aggressive nuclear construc-

\section{Figure ES1. Percent Net U.S. Utility Electricity Generation by Fuel Type, 1993}

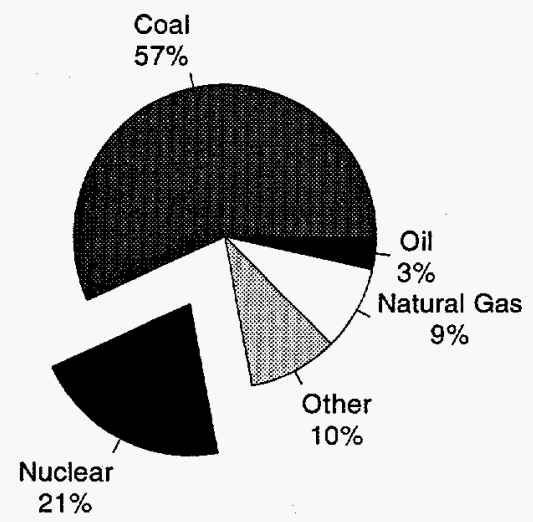

Note: Other includes hydro, geothermal, wood, waste, wind, photovoltaic, and solar thermal energy sources connected to electric utility distribution systems.

Source: Energy Information Administration, Monthly Energy Review July 1994, DOE/EIA-0035(44/07).

tion programs, had a combined total of 23 units under construction, with a total capacity of $19.5 \mathrm{GWe}$.

\section{Worldwide Nuclear Capacity Projections}

Nuclear capacity is projected to increase slightly from 338.1 GWe in 1993 to 354.7 GWe in the Low Case and to $410.3 \mathrm{GWe}$ in the High Case by 2010 (Figure ES2), representing an annual growth rate between 0.3 and 1.1 percent. The Low Case capacity projection reflects the fact that a nuclear moratorium or a slowdown in construction is in effect in Belgium, Bulgaria, Canada, Cuba, Finland, Germany, Italy, Lithuania, Netherlands, Spain, Sweden, Switzerland, and the United Kingdom. In addition, the nuclear construction program in Russia has been slowed as the country implements a program to improve the safety of its RBMK reactors. The Ukrainian parliament has recently lifted its moratorium on commissioning new nuclear units and, in addition, reversed its earlier decision to permanently shut down

\footnotetext{
${ }^{1}$ Revised from last year's published generation of 2,023.1 TWh. See Energy Information Administration, World Nuclear Capacity and Fuel Cycle Requirements 1993, DOE/EIA-0436(93) (Washington, DC, November 1993).

${ }^{2}$ All capacity ratings and electricity generation in this report represent net values.
} 
Figure ES2. 1993 World Nuclear Capacity and Projected Capacity for 2010

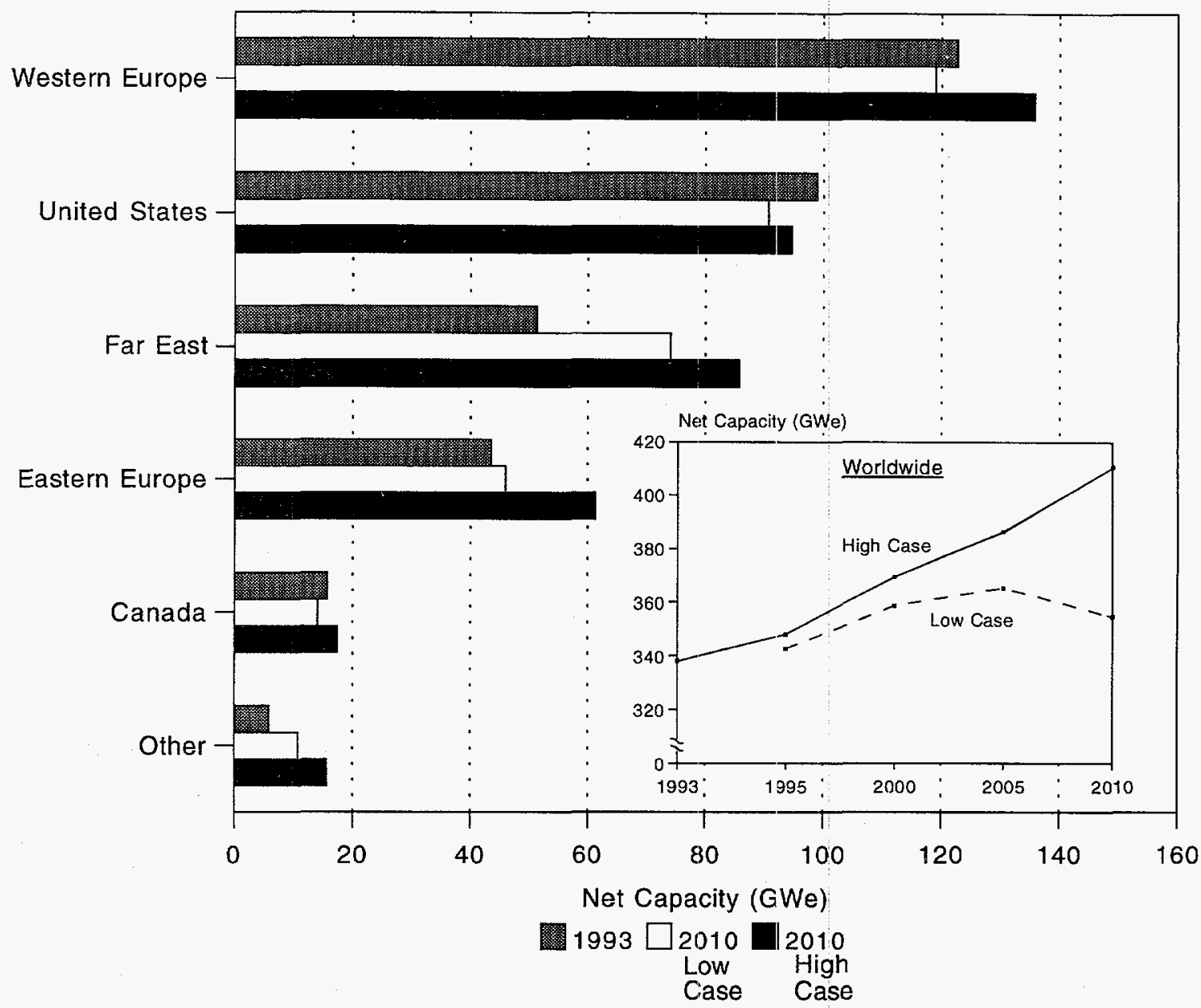

Sources: 1993-United States, Nuclear Regulatory Commission, "Information Digest, 1994 Edition" (NUREG-0380) (May 1994): Foreign, International Atomic Energy Agency (IAEA), "Nuclear Power Reactors in the World" (Vienna, Austria, April 1994). Projections--Energy Information Administration, "World Integrated Nuclear Evaluation System" (WINES April 1994 run). The remaining projections are based on a critical assessment of detailed country-specific nuclear power plans. Information used in developing the projections for the countries of Eastern Europe, the People's Republic of China, Cuba, and North Korea was obtained from the International Atomic Energy Agency's 1994 Consultancy Meeting on International Nuclear Capacity Forecasting.

the Chernobyl 1 and 3 units in 1993. Worldwide, the High Case capacity projection is about 17 GWe lower than last year's High Case projection. The decrease is largely the result of lower projections for Canada and the United States. Because of Canada's large capacity reserve margins and falling electricity demand, Ontario Hydro, the country's largest utility, is currently downsizing its present capacity and has, therefore, decided on early shutdowns for the Bruce 1 and 2 units. With the scheduled closing of the Bruce 1 and 2 units, the Low Case projection for Canada shows a decline from 15.8 GWe total nuclear capacity in 1993 to $14.1 \mathrm{GWe}$ in 2010.
The United States nuclear capacity is projected to decline slightly from 99.0 GWe in 1993 to 90.7 GWe in 2010 in the Low Case and to 94.7 GWe in the High Case. Only four U.S. units (Watts Bar 1 and 2 and Bellefonte $\mathbb{I}$ and 2 ) are actively under construction. All four are owned by Tennessee Valley Authority (TVA). Under the provisions of the Energy Policy Act of 1992, however, TVA is required to use the Integrated Resource Planning (IRP) process to determine whether a plant will be completed. The Watts Bar 1 nuclear unit is exempt from the IRP and is expected to receive its full-power license in 1995. By the end of 1995, TVA officials will decide whether to continue work on the remaining units. 


\section{World Demand for Uranium and Enrichment Services}

Uranium usage from 1994 through 2010 for commercial nuclear reactors throughout the world is projected to be between 2.5 and 2.7 billion pounds. On average, worldwide use of uranium from 1994 through 2010 will be between 144 and 155 million pounds per year. Some uranium may be displaced by the use of plutonium in mixed-oxide fuel, but this will not significantly affect the use of uranium. Currently, four countries in Western Europe are using mixed-oxide fuel; Japan is expected to start using mixed-oxide fuel in a demonstration program in 1995.

Requirements for enrichment services worldwide from 1994 through 2010 are projected to be between 527 and 569 million separative work units (SWU). Annual SWU requirements will vary between 27 and 40 million per year. The current worldwide enrichment capacity of 46.7 million SWU is more than enough to meet the expected demand.

\section{Uranium Market Developments}

For more than a decade, the world has had an oversupply of uranium, a trend that is likely to persist over the next several years. As a result, the average Nuexco unrestricted spot-market price declined to $\$ 7.12$ per pound $\mathrm{U}_{3} \mathrm{O}_{8}$ in 1993 , compared to $\$ 7.95$ per pound in 1992. A two-tiered market developed in the United States following the suspension agreements that restrict imports from the republics of the Former Soviet Union (FSU). During 1993, these agreements produced a spotmarket price in the United States that was $\$ 2$ to $\$ 3$ per pound higher for non-FSU uranium than for FSU uranium.

Two prevailing factors led to declining uranium prices in the West since the early 1980 's. For several years, new uranium production had to compete with the liquidation of excess producer and utility inventories that had built up after delays and cancellations of reactor construction programs. More recently, exports of uranium from the Former Soviet Union and, to a lesser extent, from China contributed to the weakness in uranium prices.

Over the forecast period, spot-market prices are likely to rise modestly in the near term to reflect the continuing effect on the uranium market of the sus- pension agreements and the amendment to the agreement with Russia. Beyond the near term, as the effect of inventory drawdowns diminishes, new uranium production is likely to be undertaken to meet demand. A gradual price increase is projected. The spot price (in constant 1993 dollars) is expected to be slightly higher than $\$ 13$ per pound $\mathrm{U}_{3} \mathrm{O}_{8}$ by 2005 .

The U.S. uranium mining and milling industry developed nonconventional mining methods such as uranium recovery by in situ leaching in the 1950's and 1960 's. Since 1980, nonconventional mining methods have contributed a significant share to domestic production. In 1993, in situ leaching and recovery of uranium as a byproduct of phosphate mining accounted for almost all of the 3.1 million pounds of U.S. uranium production.

Projections of uranium production reflect a higher cost for domestic operations than for those of other countries. Consequently, a large share of domestic demand is likely to be met by imports. The modest but continuing increase projected for uranium prices should induce annual domestic production to rise gradually to 5.2 million pounds in 2000 . As the price trajectory continues its upward trend, domestic uranium production is expected to reach 7.7 million pounds by 2004 but decline slightly to 7.4 million pounds in 2005 .

\section{Commercial Spent Fuel}

Management of spent fuel from nuclear reactors is important for all countries with nuclear power programs. Concerns about how spent fuel will be stored and ultimately disposed of will continue to grow as the volume of discharges increases. Worldwide, total spent fuel discharges from 1994 through 2010 are projected to range from 169 thousand to 176 thousand metric tons of uranium (MTU) worldwide. Most countries have chosen reprocessing as the method for managing their spent fuel, although many countries have deferred the decision while different approaches are evaluated. The United States and Canada are currently the only countries relying entirely on direct disposal of spent fuel. The United States is currently evaluating Yucca Mountain, Nevada, as a potential site for permanent disposal of commercial spent fuel and other high-level radioactive waste. By the end of 1993, commercial nuclear reactors in the United States had discharged approximately 28.0 thousand MTU of spent fuel. The total is expected to reach 62.5 thousand MTU by 2010 . 


\section{Introduction}

\section{Introduction}

This report presents the status of nuclear power at the end of 1993 for all countries with commercial nuclear power programs. The report also contains projections of nuclear capacity, electricity generation, nuclear fuel requirements, and spent fuel discharges throughout the world. New to this report is a section covering current U.S. uranium market developments and projections of uranium prices, imports, inventories and production. This section contains information and analysis that was previously reported in the Energy Information Administration's (EIA's) annual report on the viability of the uranium mining and milling industry in the United States. ${ }^{1}$ Controlling Operating and Maintenance (O\&M) costs is a major concern to utilities with nuclear power plants; therefore, we have included a new chapter on O\&M costs of nuclear power plants in the United States. This Chapter also contains some information on U.S. nuclear reactor capacity factors.

The U.S. Department of Energy's (DOE) Office of Civilian Radioactive Waste Management (OCRWM) uses the projections of capacity, generation, and spent fuel discharges in the United States for estimating nuclear waste fund revenues, planning construction of a permanent waste repository, and preparing an annual report to Congress. Also, the DOE's Assistant Secretary for Policy uses the report for information on the status and outlook of nuclear power worldwide. Projections of nuclear capacity, fuel requirements and uranium production contained in this report are provided to the Organization for Economic Cooperation and Development and the International Atomic Energy Agency.

Chapter 2 of this report focuses on the status of nuclear power in the world by regional breakdown, including a detailed presentation of nuclear capacity projections through 2010, followed by a summary of important events that occurred in the regions in 1993 and the early months of 1994 . Nuclear capacity projections are developed for two scenarios, a Low Case and a High Case. These scenarios are developed from an analysis of nuclear reactor construction schedules and retire- ments for each country, supplemented with projections, as deemed appropriate.

Chapter 3 contains worldwide projections of reactor requirements for uranium and enrichment services for the Low and High Cases. These requirements are based on an estimate of reactor demand-that is, the actual amount of uranium and enrichment services necessary to fuel and operate the nuclear reactors. Projections of spent fuel discharges worldwide are discussed along with a presentation of the status of the spent fuel program in the United States. New to this report, in Chapter 3 , is a discussion of world uranium market developments, with an emphasis on the U.S. market. Projections of uranium prices, U.S. imports, uranium inventories, and uranium production are discussed.

Chapter 4 presents a fairly extensive discussion on the O\&M costs of nuclear power plants in the United States from 1981 through 1992. Reasons for the increased O\&M costs are discussed along with efforts to control these costs.

Chapter 5 contains a comparison of EIA's projections with those of other organizations involved in the evaluation, analysis, and reporting of information on the nuclear and uranium industries.

Appendix A briefly describes nuclear power technology and the nuclear fuel cycle. Appendix B contains a discussion of the computer models and input assumptions used for the analysis and projections in this report. Appendices C and D are lists of nuclear reactors that were in operation and under construction at the end of 1993. Appendix E includes projections of nuclear capacity, generation, and spent fuel for three nuclear supply scenarios in the United States through 2040. Appendix $F$ lists nuclear fuel cycle facilities that convert, enrich, and fabricate fuel for use in nuclear units. Appendix $\mathrm{G}$ contains a discussion of the United States' antidumping petition/suspension agreements with countries in the former Soviet Union and the agreement with Russia to purchase highly enriched uranium from dismantled nuclear weapons. Appendix $\mathrm{H}$ shows selected tables in metric units.

\footnotetext{
${ }^{1}$ The report, Domestic Uranium Mining and Milling Industry: Viability Assessment, was required by Section 170B of the Atomic Energy Act of 1954, as amended by Public Law 97-415 (the Nuclear Regulatory Commission Authorization Act of 1983.) Last year's report, the 1992 assessment, was the last one required by the statute.
} 


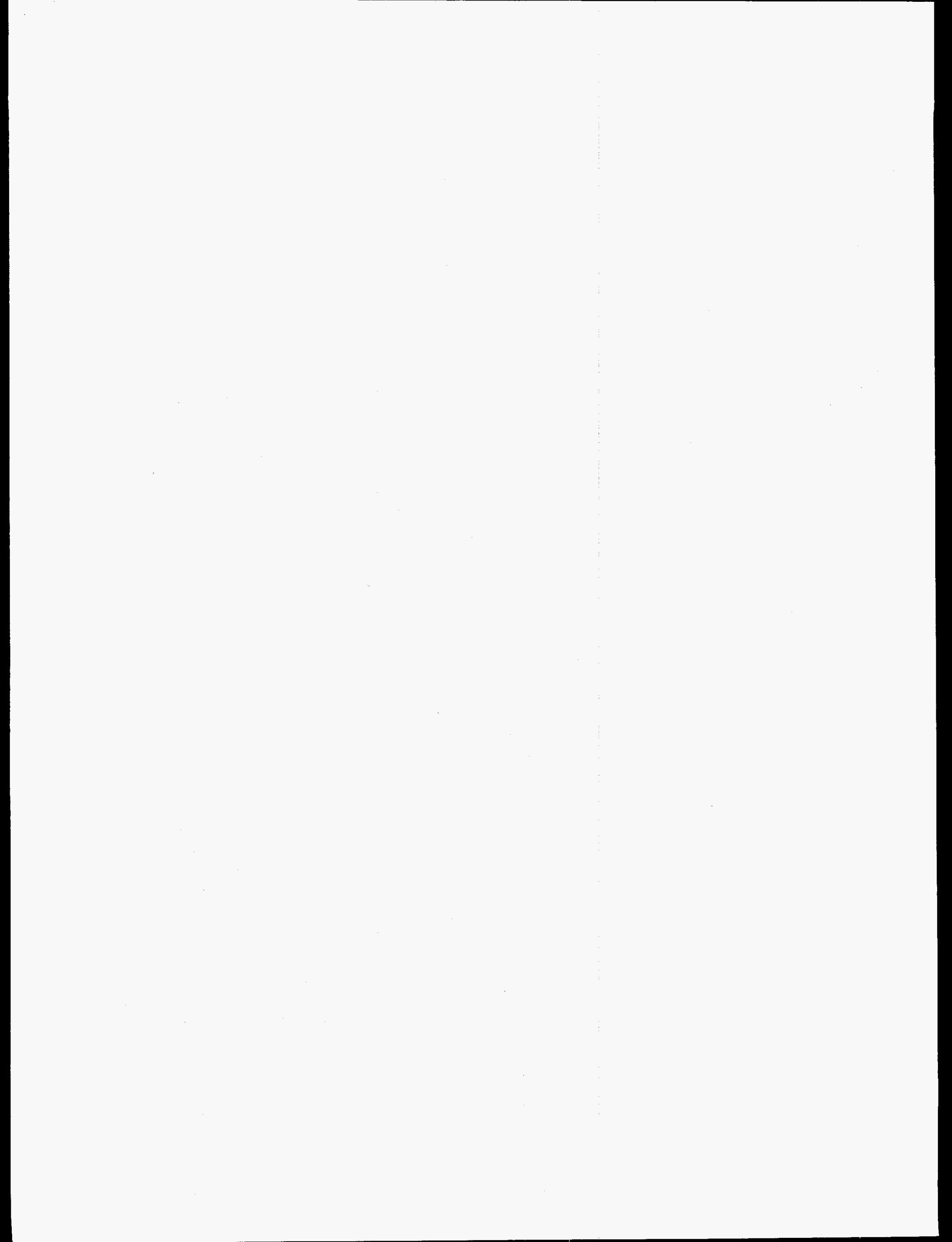




\section{Nuclear Capacity Status and Projections}

This chapter highlights some of the main events that occurred in the nuclear industry in 1993 and presents the Energy Information Administration's (EIA's) worldwide nuclear power projections for 1994 through 2010. Following a summary of worldwide developments, the discussion is organized by the following regional categories: (1) United States, (2) Canada, (3) Western Europe, (4) Eastern Europe, (5) Far East, and (6) Other. Current events within each region are described, as well as the assumptions underlying EIA's nuclear capacity projections.

The information contained in this chapter was derived from diverse sources. ${ }^{2}$ Nuclear reactors mentioned in the regional discussions but not included in the rosters of units in the construction pipeline (Appendix D) are units that were not projected to become operable in the 2010 forecast.

\section{World Nuclear Power}

\section{Current Status}

At the end of 1993, there were 430 commercial nuclear. units operating in 30 countries throughout the world, with a total capacity of 338.1 net gigawatts-electric (GWe) (Table 1). This was a net increase of six units and 7.2 GWe from 1992. Nine nuclear units were connected to the electrical grids in six countries during the year. Four units were connected to the grid in Japan: Genkai 3, a 1,127-megawatt-electric (MWe) pressurized light-water-moderated and cooled reactor (PWR); Hamaoka 4, a 1,092-MWe boiling-light-watercooled and moderated reactor (BWR); Kashiwazaki Kariwa 4, a 1,067-MWe BWR; and Shika 1, a 505-MWe $B W R$. The four new units increased Japan's total nuclear capacity to $38.0 \mathrm{GWe}$. Canada, China, France, Russia, and the United States each had one unit coming on-line during the year. Canada connected Darlington 4, an 881-MWe pressurized-heavy-water-moderated and cooled reactor (PHWR), to its electrical grid. In September 1993, the People's Republic of China connected its second unit, Guangdong 1, a 906-MWe PWR, bringing the country's total operable nuclear capacity to 1.2 GWe. France connected Golfech 2, a 1,310-MWe PWR located in Valence, Tarn et Garonne. Russia connected Balakovo 4, a 950-MWe PWR, located in Balakovo, Saratov. The United States connected Comanche Peak 2, a 1,150-MWe PWR.

Three nuclear units were officially shut down in 1993, Trawsfynydd 1 and 2 and Trojan 1 . The Trawsfynydd plant, located in the United Kingdom, is a two-unit 195MWe gas-cooled, graphite-moderated reactor (GCR) that had not operated since February 1991, when embrittlement of the reactor's pressure vessels was discovered. In the United States, Trojan 1, a 1,104-MWe PWR, shut down permanently in January 1993 because the owner, Portland General Electric Co., decided it was uneconomical to repair the plant's steam generators.

The United States led all countries in nuclear capacity with 99.0 GWe in 1993, followed by France ( $59.0 \mathrm{GWe})$, Japan (38.0 GWe), Germany (22.7 GWe), Russia (19.8 GWe), Canada (15.8 GWe), and Ukraine (12.7 GWe) (Figure 1). Combined, these seven countries accounted for 79 percent of the world's nuclear capacity used for generating electricity. World nuclear-generated electricity equaled 2,093.4 net terawatthours (TWh), a 3.3percent increase over the 2,027.4 net TWh in 1992. ${ }^{3}$

As of December 31, 1993, 94 units with a total capacity of 81.2 GWe were in the construction pipeline (Table 2). Of these, 52 were less than 26 percent complete. Japan, whose nuclear construction program far surpasses that of any other country, has 19 units in the construction pipeline with a total capacity of $20.1 \mathrm{GWe}$, including 3 units that are more than 75 percent complete. By comparison, France, India, and South Korea, which also have aggressive nuclear construction programs, have a combined total of 23 units in the construction pipeline with a total capacity of 19.5 GWe.

\footnotetext{
${ }^{2}$ Primary sources of information in this chapter include various issues of Nuclear Engineering International (Surry, United Kingdom: Business Press, Ltd); Nuclear News (LaGrange, Illinois: American Nuclear Society); Nuexco, 1993 Annual Nuexco Review (Denver, CO, 1993); NUKEM Market Report (Stamford, Connecticut); Nuclear Fuel and Nucleonics Week (New York: McGraw-Hill). Most of the sources reflect information reported through April 30, 1994, but a few sources include information reported through May 1994.

${ }^{3}$ Revised from last year's published generation of 2,023.1 TWh. See Energy Information Administration, World Nuclear Capacity and Fuel Cycle Requirements 1993, DOE/EIA-0436(93) (Washington, DC, November 1993).
} 
Table 1. Operable Nuclear Power Plant Statistics, 1992 and 1993

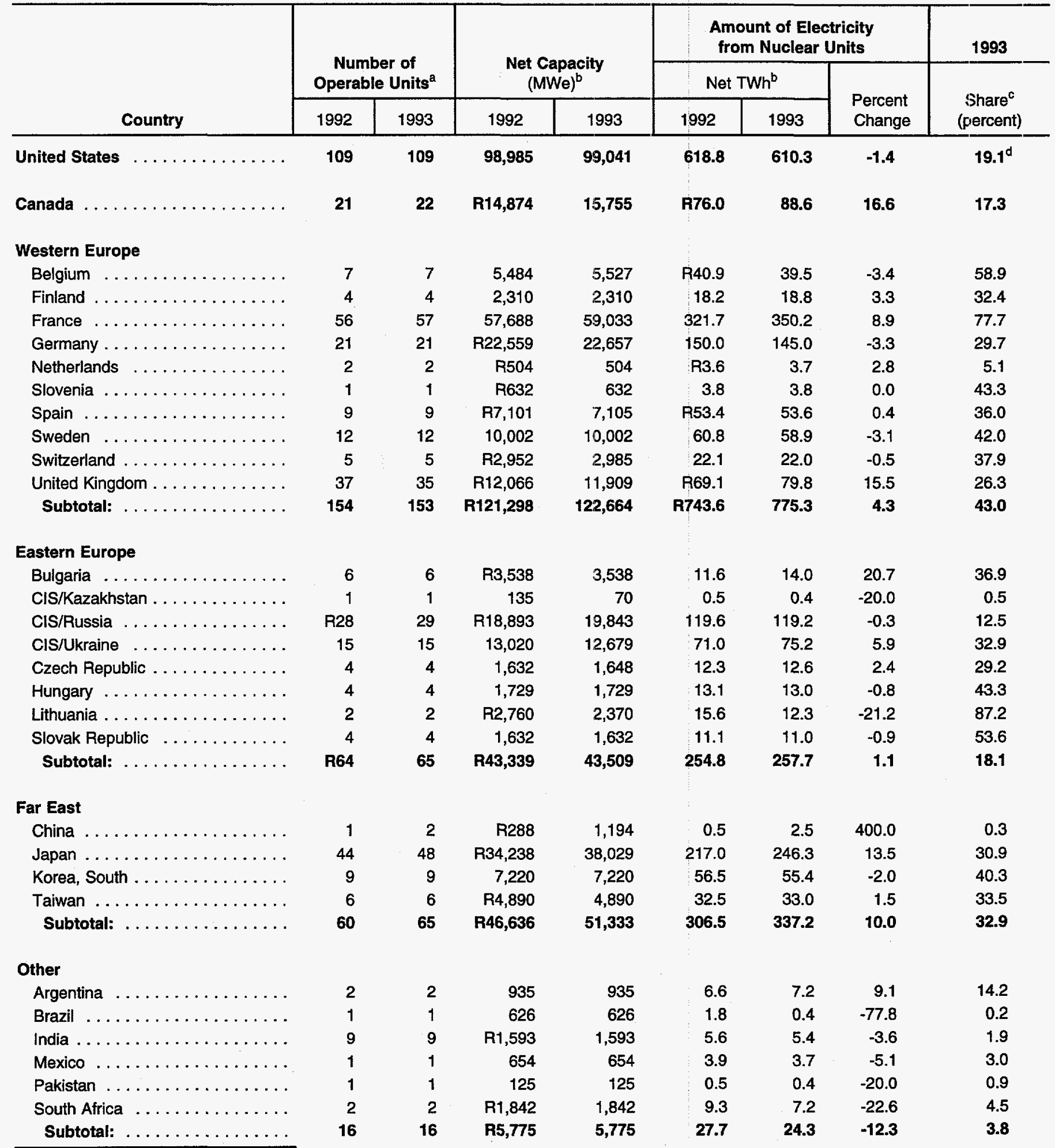

See footnotes at end of table. 
Table 1. Operable Nuclear Power Plant Statistics, 1992 and 1993 (Continued)

\begin{tabular}{|c|c|c|c|c|c|c|c|c|}
\hline \multirow[b]{3}{*}{ Country } & \multirow{2}{*}{\multicolumn{2}{|c|}{$\begin{array}{c}\text { Number of } \\
\text { Operable Units }^{a}\end{array}$}} & \multirow{2}{*}{\multicolumn{2}{|c|}{$\begin{array}{l}\text { Net Capacity } \\
\left(_{(M W e)^{b}}\right.\end{array}$}} & \multicolumn{3}{|c|}{$\begin{array}{l}\text { Amount of Electricity } \\
\text { from Nuclear Units }\end{array}$} & \multirow{3}{*}{ 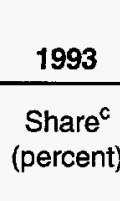 } \\
\hline & & & & & \multicolumn{2}{|c|}{ Net $T W^{b}$} & \multirow{2}{*}{$\begin{array}{l}\text { Percent } \\
\text { Change }\end{array}$} & \\
\hline & 1992 & 1993 & 1992 & 1993 & 1992 & 1993 & & \\
\hline Total World & R424 & 430 & $\mathrm{R} 330,90$ & 338,077 & R2,027.4 & $2,093.4$ & 3.3 & 25.5 \\
\hline
\end{tabular}

${ }^{a}$ For all non-U.S. units, operable units are those that have generated electricity to the grid. An operable unit in the United States is one that has been issued a full-power license from the U.S. Nuclear Regulatory Commission. For all non-U.S. units, capacity is the net design electrical rating. For U.S. units, capacity is net summer capability. Capacities of individual units are subject to reratings from year to year. See definitions of capacities in glossary.

${ }^{\mathrm{M}} \mathrm{MWe}=$ megawatt-electric; TWh = terawatthours.

'Each country's net electricity generated from nuclear power generating units as a percentage of net electricity generated from utilities and nonutilities. The source for nuclear generation data is the International Atomic Energy Agency (IAEA). The nuclear share of utilitygenerated electricity for the United States was 21.2 percent.

${ }^{d} 1993$ utility generation was obtained from the Energy Information Administration, Monthly Energy Review, May 1994, DOE/EIA0035(94/05) (Washington, DC, May 1994). Forecasted 1993 gross nonutility generation data was obtained from the Energy information Administration, Projection for the Short-Term Energy Outlook Memorandum, June 9, 1994.

$\mathrm{R}=$ Revised.

Sources: 1992-International Atomic Energy Agency, Nuclear Power Reactors in the World (Vienna, Austria, April 1993). 1993-International Atomic Energy Agency, Nuclear Power Reactors in the World (Vienna, Austria, April 1994).

Figure 1. Nations With the Largest Nuclear Generating Capacity, 1993

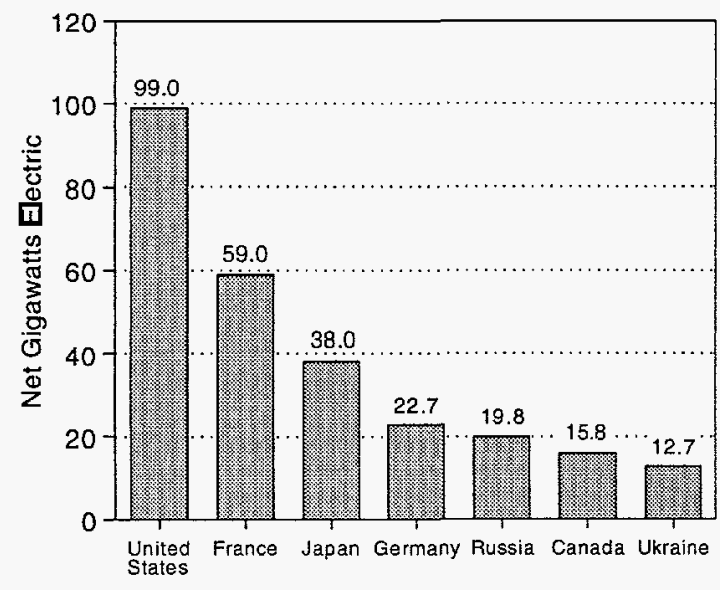

Source: Table 1.

\section{Outlook}

\section{Methodology}

The EIA's projections of operable nuclear capacity by country are derived from two different methodologies. (1) Projections of nuclear capacity are initially based on an analysis of each country's current nuclear construction program. From this analysis, estimates of completion dates for planned reactors and reactors currently under construction are developed. (2) If a country's construction pipeline is exhausted before 2010, the World Integrated Nuclear Evaluation System (WINES) model is used to supplement the 2010 capacity projection. The primary objective of the WINES model is to produce long-term projections of world energy, electrical generation, and most importantly, nuclear capacity. Within the WINES model framework, assumptions of economic growth and energy consumption are developed from a statistical analysis of historical data for each country's nuclear power program. ${ }^{4}$ However, the projections for countries listed under the Eastern Europe region (Armenia, Bulgaria, Czech Republic, Hungary, Kazakhstan, Lithuania, Romania, Russia, Slovak Republic and Ukraine) in addition to China and Cuba, were not derived using the WINES model since the economic and energy input data needed to run WINES for these countries were either unavailable or deemed to be unreliable. Their projections are based solely on a critical assessment of detailed country-specific nuclear power plants and information obtained from the International Atomic Energy Agency (IAEA) 1994 Consultancy Meeting on International Nuclear Capacity Forecasting.

Two scenarios, the High Case and the Low Case, have been developed which represent nuclear capacity projections that vary as a result of different assumptions about the operating lives of existing and newly ordered nuclear units. A Mid Case for the United States, which

${ }^{4}$ Appendix B contains a discussion of the economic and energy input assumptions used in the WINES model. 
Table 2. Status of Commercial Nuclear Generating Units in the Construction Pipeline as of December 31, 1993

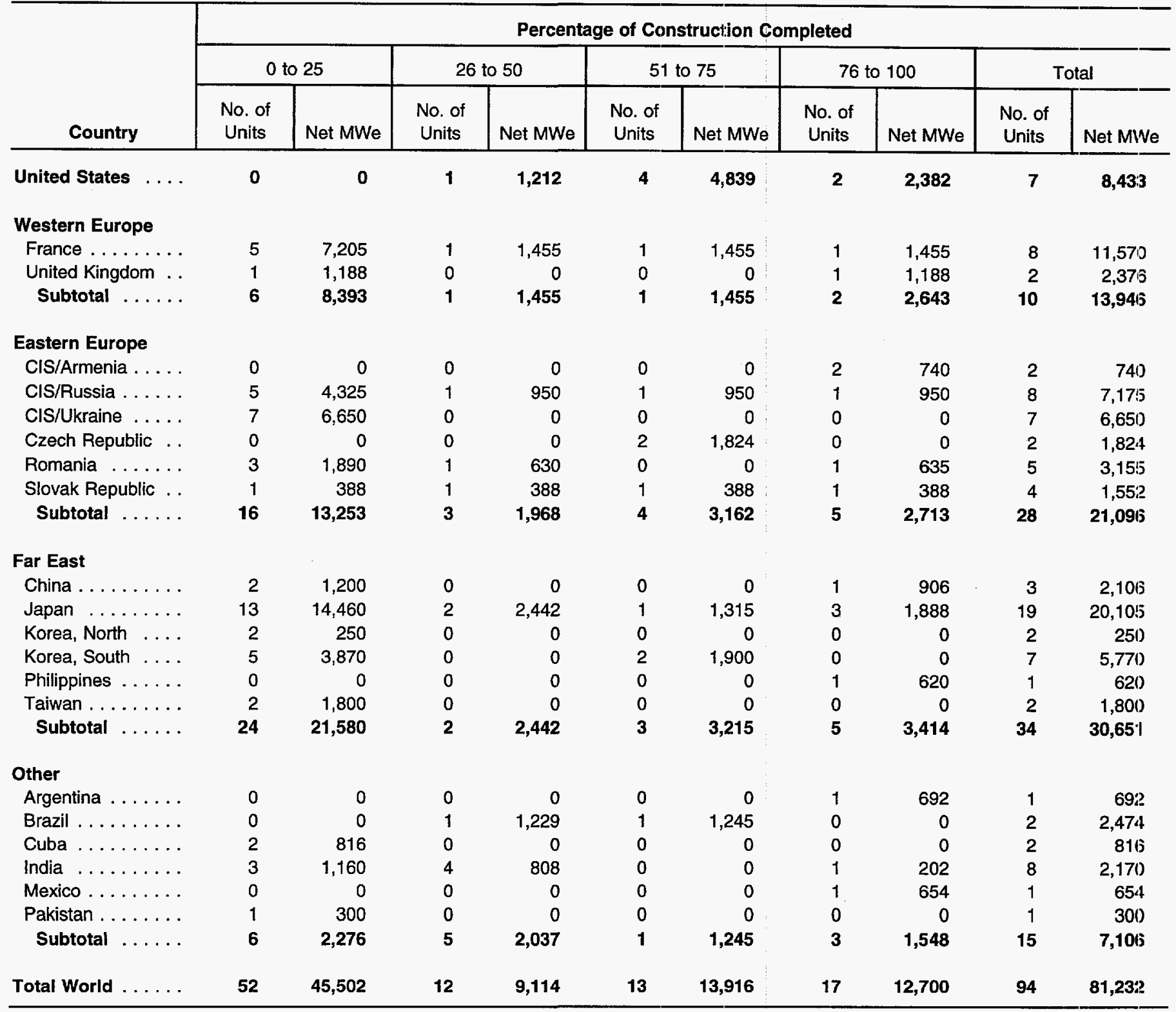

Note: $M W e=$ Megawatts-electric.

Source: "World List of Nuclear Power Plants," Nuclear News (March 1994), pp. 43-62. Nucleonics Week (various issues).

is discussed in Appendix $\mathrm{E}$, has also been developed. These three cases should not be interpreted as exhausting the range of possible nuclear supply futures.

High Case: The High Case is an accelerated growth case, which assumes that each country's unfinished nuclear units will be completed but not necessarily operational by 2010. Estimates of operation dates for nuclear units actively under construction reflect historical construction performance, regulatory or financial constraints, and regional electricity demand considerations. ${ }^{5}$ The WINES model was used for the 2010 High Case projection for the following countries: Argentina, Belgium, Canada, Finland, Germany, India, Italy, Mexico, Netherlands, Pakistan, South Africa, South Korea, Spain, and Taiwạn.

${ }^{5}$ Appendix $\mathrm{D}$ contains the estimated completion date of units in the construction pipeline. 
Low Case: In this scenario, unfinished units are assumed to be completed at a slower rate than in the High Case. The Low Case capacity projections are based solely on units in the construction pipeline and the expected retirement dates of existing reactors.

\section{Projections}

Reflecting existing conditions, both the High and Low Cases represent limited or no growth of nuclear power in many countries. Currently, a nuclear moratorium or a slowdown in construction is in effect in Belgium, Bulgaria, Canada, Cuba, Finland, Germany, Italy, Lithuania, Netherlands, Spain, Sweden, Switzerland, and the United Kingdom. By 2010, nuclear capacity is projected to be 354.7 GWe in the Low Case and 410.3 GWe in the High Case (Table 3), a difference of 16.5 GWe from last year's 2010 projection. Much of the increase in capacity for the world in 2010 emerges from the Far East region, with Japan, South Korea, and Taiwan accounting for 93 percent of the 85.7 GWe projected for the region by 2010 .

\section{Regional Developments and Projections}

\section{Introduction}

By 2000 roughly one-quarter of the world's operable nuclear power units will be at least 25 years old. With the life of a reactor ranging from 25 to 40 years, plant aging is a factor many countries are facing. Even with reactor aging, worldwide nuclear capacity is expected to grow at an annual rate of 0.3 to 1.1 percent over the next 17 years. A number of countries-including Canada, the United Kingdom, and the United States-have few if any plants in the construction pipeline. Although Russia and Ukraine have more than 10 units in the construction pipeline, they too are projected to have very low growth by 2010 . For these countries the question of new nuclear capacity is currently overshadowed by the question of whether to extend the lives of existing plants. Along with age-related issues, the future of nuclear power will depend on economics, public perception, and nuclear waste storage.

\section{United States}

As of December 31, 1993, the list of operable nuclear power plants in the United States included 109 nuclear units with a total net capacity of $99.0 \mathrm{GWe}$. One unit received a full-power license in the United States during the year. In April, Texas Utilities Electric Company's Comanche Peak 2, a 1,150-MWe PWR, became the 109th operable nuclear unit in the country. The plant had been plagued by setbacks as a result of controversy over fire barrier material that was used in the construction of the Comanche Peak 1 unit. The completion and successful grid connection of Comanche Peak 2 marked the first new nuclear unit to begin operation since April 1990, when Comanche Peak 1 was connected to the grid.

A total of 610.3 net TWh of electricity was produced from the 109 units in 1993, a slight decrease of 8.5 TWh from the record 1992 generation of 618.8 net TWh (Table 4). ${ }^{6}$ Until 1993, total U.S. nuclear generation had increased every year since 1980, as new plants came online and reactor performance improved in the late 1980 's and early 1990's. Along with the decreased generation in 1993, the U.S. capacity factor dropped slightly, to 70.5 percent, from last year's all-time high of 70.9 percent. $^{7}$

U.S. utilities generated 21.2 percent of their electricity from nuclear plants in 1993, compared with 22.1 percent in 1992-a 4 percent decrease. ${ }^{8}$ This decrease is mostly attributed to unexpected outages at several units, such as the Brunswick nuclear plant located in Southport, North Carolina, which had an extended outage during the year. Six of the 10 regions in the United States generated more than 20 percent of their electricity from nuclear power plants, led by New England (52.8 percent) and New York/New Jersey (36.9 percent).

The Three Mile Island accident in 1979 ignited a strong public and regulatory reaction that redefined acceptable safety standards for U.S. nuclear power plants. The new and more stringent regulations adversely affected both operating nuclear units and those that were under construction, lengthening an already long construction time for unfinished plants. Most of the plants that were under construction in the early 1980's were either completed or canceled. As of December 31, 1993, only seven units remained in the construction pipeline, three of which the U.S. Nuclear Regulatory Commission (NRC) classified as indefinitely deferred (Table 5).

The Tennessee Valley Authority (TVA) has four nuclear units in the construction pipeline: Bellefonte 1 (80 percent complete), Bellefonte 2 (45 percent), Watts Bar

\footnotetext{
${ }^{6}$ Energy Information Administration, Monthly Energy Review (MER), DOE/EIA-0035(94/05) (Washington, DC, May 1994$)$, p. 101.

${ }^{7}$ Energy Information Administration, Monthly Energy Review, DOE/EIA-(0035(94/05) (Washington, DC, May 1994), p. 100.

${ }^{8}$ Energy Information Administration, Monthly Energy Review, DOE/EIA-(0035(94/05) (Washington, DC, May 1994), p. 100.
} 
Table 3. 1993 Operable Nuclear Capacities and Projected Capacities for 1995, 2000, 2005, and 2010 (Net Gigawatts-Electric)

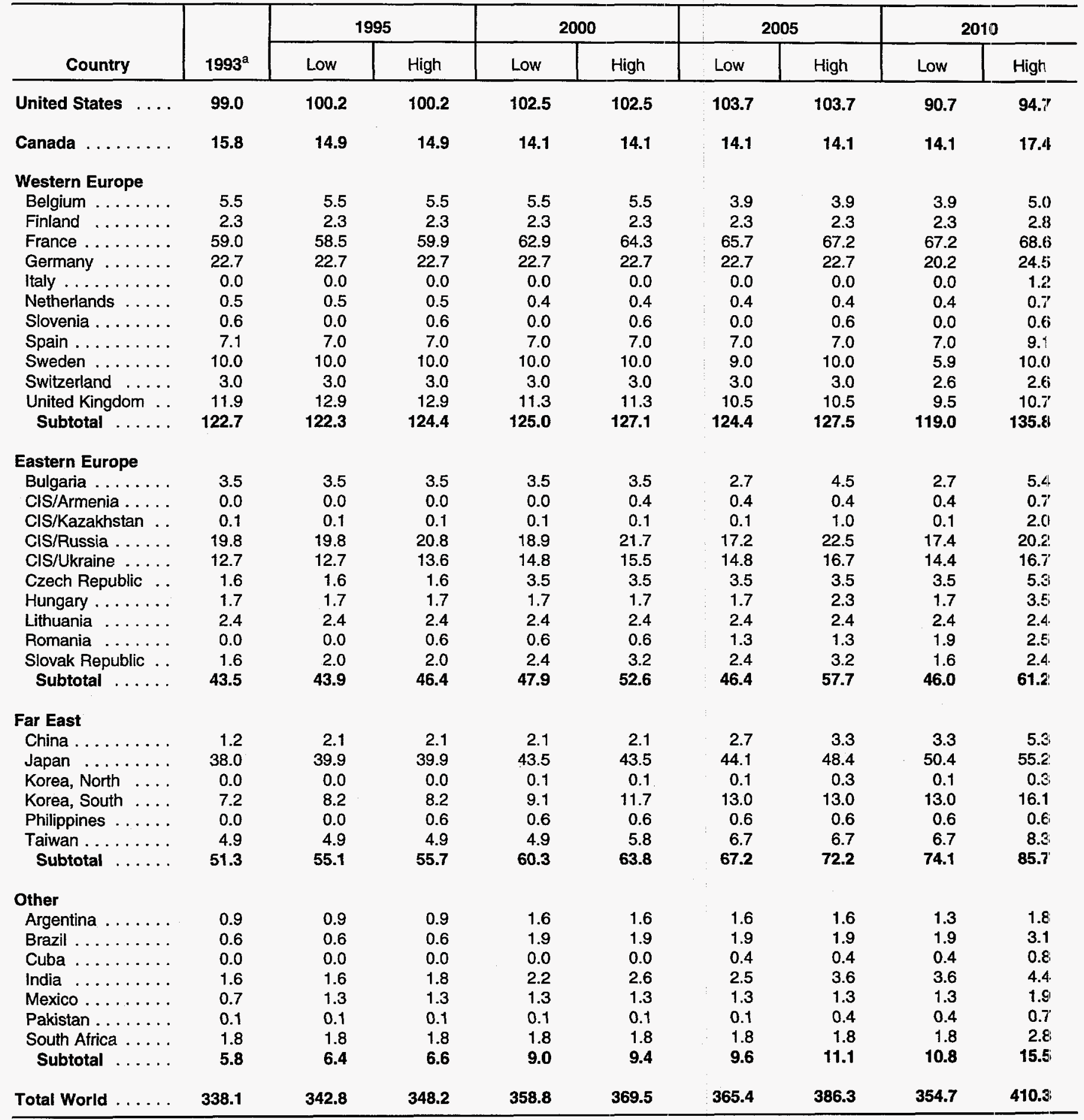

astatus as of December 31, 1993.

Note: Totals may not equal sum of components due to independent rounding.

Sources: 1993-United States, Nuclear Regulatory Commission, "Information Digest, 1994 Edition" (NUREG-0380) (May 1994); Foreign, International Atomic Energy Agency (IAEA), "Nuclear Power Reactors in the World" (Vienna, Austria, April 1994). Projections-Energy Information Administration, "World Integrated Nuclear Evaluation System" (WINES April 1994 run). The remaining projections are based on a critical assessment of detailed country-specific nuclear power plans. Information used in developing the projections for the countries of Eastern Europe, the People's Republic of China, Cuba, and North Korea was obtained from the International Atomic Energy Agency's 1994 Consultancy Meeting on International Nuclear Capacity Forecasting. 
Table 4. U.S. Nuclear Capacity and Generation as of December 31, 1993, by Federal Region

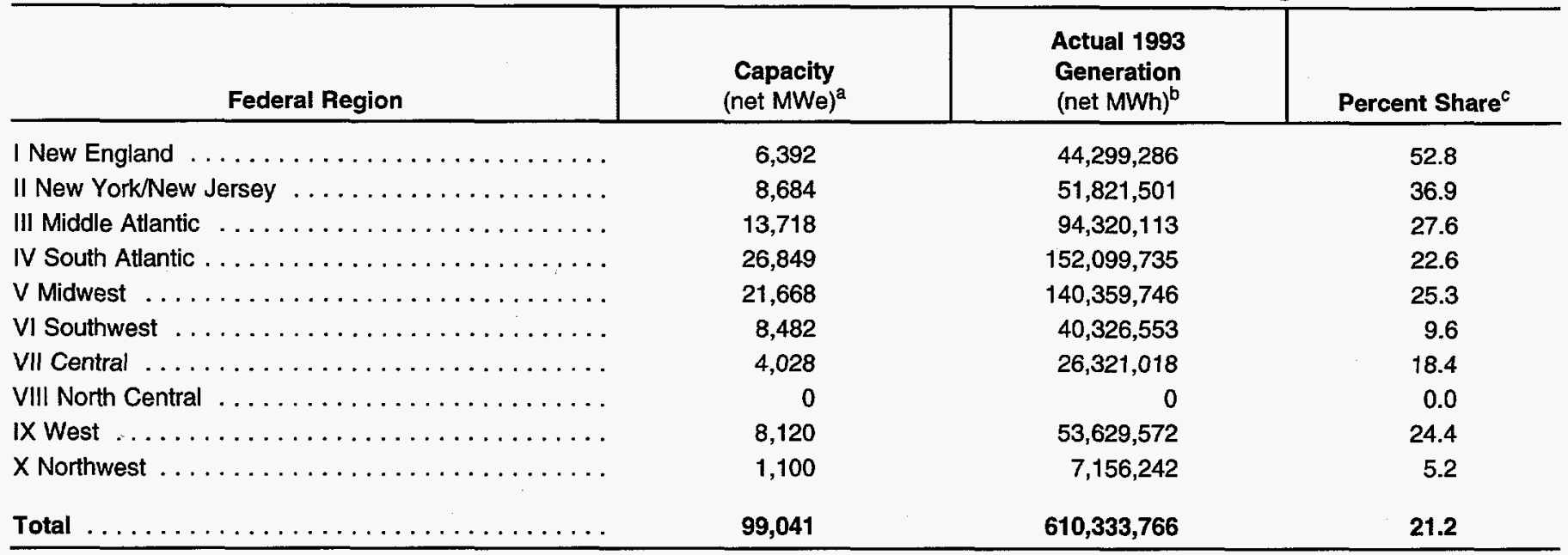

${ }^{a} \mathrm{MWe}$, Megawatt-electric $=$ One million watts of electrical capacity.

${ }^{b} \mathrm{MWh}$, Megawatthours = One million watthours of electric energy.

'Nuclear-generated electricity as a percentage of utility-generated electricity. Non-utility generated electricity is not included.

Note: Totals may not equal sum of components due to independent rounding.

Source: Energy Information Administration, Form ElA-759, "Monthly Power Plant Report."

Table 5. Power Plant Statistics for the United States, 1993

\begin{tabular}{|c|c|c|c|c|c|c|c|}
\hline United States & 109 & 99,041 & 7 & 8,433 & 71 & 610.3 & 19.1 \\
\hline
\end{tabular}

${ }^{\mathrm{a}} \mathrm{MWe}=$ Megawatt electric.

bTWh = Terawatthours.

'Net electricity generated from nuclear power generating units as a percentage of net electricity generated from utilities and nonutilities. The nuclear share of utility-generated electricity for the United States was 21.2 percent.

Source: Table 1. 1993 Capacity Factor: Energy Information Administration, Monthly Energy Review, DOE/EIA-0035(94/06) (Washington, DC, June 1994), p. 105.

1 (86 percent), and Watts Bar 2 (70 percent). Under the provisions of the Energy Policy Act of 1992, TVA is required to use the Integrated Resource Planning (IRP) process in determining its long-term nuclear policy. The IRP process will compare the cost of new nuclear units with the cost of other options, including repowering existing plants, building new fossil plants, and purchasing independent power. TVA expects to have a draft IRP by June 1995. After receiving comments on the draft, the TVA board will approve a final plan by December 1995. Since TVA is not regulated by a State public utility commission, the draft will not be subject to further review. ${ }^{9}$ By the end of 1995, TVA officials will decide whether to restart Brown's Ferry $1^{10}$ and continue work on three nuclear units-Watts Bar 2, and Bellefonte 1 and $2 .^{11}$ If the units pass the IRP, TVA expects them to become operable between 1999 and 2005. The company has spent more than $\$ 6$ billion on the plants still in construction and estimates that $\$ 4.1$ to $\$ 4.8$ billion will be needed to complete them. ${ }^{12}$

In 1993, the issue of degradation and possible replacement of the steam generators was still in the spotlight. On July 14, 1993, Northern States Power joined the list

"Lacrisha Butler, "Nuclear the Way, Says TVA," The Tennessean (Nashville, TN, March 10, 1994), p. A1.

${ }^{10}$ Browns Ferry 1 nuclear unit received its full-power operating license in December 1973. In 1985, TVA officials decided to close the plant until it could be proven to be operated in a safe manner. The unit does, however, retain its operating license and is listed as an operable unit (see Appendix C.).

${ }^{11}$ Lacrisha Butler, "Nuclear the Way, Says TVA," The Tennessean (Nashville, TN) (March 10, 1994), p. A1.

${ }^{12}$ Lacrisha Butler, "Nuclear the Way, Says TVA," The Tennessean (Nashville, TN) (March 10, 1994), p. A1. 
of nuclear utilities that had filed lawsuits against Westinghouse Electric, stating that the manufacturer sold steam generators known to be defective. Currently 10 U.S. nuclear utilities have outstanding lawsuits against Westinghouse concerning steam generators. For the most part, Northern States argued that the four steam generators at its Prairie Island nuclear plant, built using the nickel-based alloy 600 , suffered serious defects in design, material, and workmanship, and that Westinghouse knew that the generators would not last the 40-year licensed operating life of a nuclear unit. ${ }^{13}$ Fifty of the 109 operable U.S. nuclear units were designed by Westinghouse.

Virginia Power's North Anna 1 nuclear unit, located in Mineral, Virginia, underwent a successful replacement of its steam generators in 1993. The Westinghouse three-loop PWR, started operation in April 1978. Virginia Power attributed its success largely to early planning, which began in 1987, prompted by continuing degradation of the tubing and consequent leaking of coolant. The replacement took 51 days and was 30 percent under budget. The entire outage was a world record of 96 days, compared with the previous record of 100 days for a steam generator replacement. ${ }^{14}$

Nuclear capacity in the United States is projected to be 90.7 GWe (Low Case) and 94.7 GWe (High Case) by 2010, a decrease of $8.3 \mathrm{GWe}$ and $4.3 \mathrm{GWe}$. The lower projections reflect the many problems that have plagued the U.S. industry. The capacity projection in the Low Case is slightly lower than the High Case because of reactor retirements. Both scenarios assume that Washington Public Power Supply System's WNP 1 and 3 units and Cleveland Electric Illuminating Company's Perry 2 unit, which are indefinitely deferred, will not come on-line during the projection period. Through the projection period, capacity factors for existing reactors remain at the level of operation achieved over the past 3 years (71 percent), and new units coming on-line in the two cases operate at an average capacity factor of 73 percent.

In the High Case, 55 operable reactors are life-extended for 20 years beyond their current retirement date. In the Low Case, all units are projected to run 40 years, which are the current license expiration dates as published by the NRC. The High Case assumes that Pacific Gas and Electric (PG\&E), the operator of Diablo Canyon 1 and 2 , will obtain a redefinition of its operating licenses.
Initially, a reactor's operating license was 40 years from the start of construction; however, most utilities have obtained a redefinition which allows operation for 40 years from the date a full-power license is issued. At the time this report was published, PG\&E was awaiting the NRC's response to its request for a redefinition.

By 1995 nuclear capacity in the United States is projected to reach 100.2 net GWe in both cases. This will be achieved by the addition of Watts Bar 1. Identical capacity is projected through 2005; however, in the High Case, Bellefonte 1 is projected to come on-line in 1998, compared with 1999 in the Low Case.

For nuclear power to remain a viable option in the United States, significant changes are required. Reactor costs and the recovery of capital and operating costs through rates charged for the electricity produced are among the most important factors affecting the future of U.S. nuclear power. ${ }^{15}$ Government and industry must develop better methods for managing the design and construction of new plants in order to ensure that State regulatory authorities allow capital costs to be recovered. A consistently high level of demonstrated utility management practices is essential for improving public attitudes toward nuclear power. Reactor standardization is also important for ensuring the highest level of safety, and realizing the potential economic benefits, modification, maintenarice, operation, and training. ${ }^{16}$ To help eliminate a major concern by utilities considering new plant orders, the selection of a permanent repository site for storing high-level waste and the development of a monitored retrieval storage facility are being evaluated.

\section{Canada}

With the addition of Darlington 4, Canada now has 22 operable ruclear units with a total operating capacity of 15.8 GWe (Table 6). Ontario Hydro $(\mathrm{OH})$, Canada's largest utility, manages 20 of the country's 22. operable reactors. The only exceptions to OH's management are the 640-MWe Gentilly 2 reactor operated by Hydro Quebec and the 635-MWe Point Lepreau 1 reactor operated by New Brunswick Electric Power Company. All of the country's units are CANDU PHWR's supplied by Atomic Energy of Canada, L.td. Total nuclear generation for Canada's operating nuclear units increased from 76.0 TWh in 1992 to 88.6 TWh in 1993.

\footnotetext{
13" Westinghouse Sued Again Over Steam Generators," Nuclear Engineering International (October 1993), p. 13.

${ }^{14}$ Leslie Spain, "Planning pays off for North Anna," Nuclear Engineering International (October 1993), pp. 30-31.

${ }^{15}$ National Research Council, Nuclear Power: Technical and Institutional Options for the Future (Washington, DC, National Academy Press, 1992), pp. 1-14.

${ }^{16}$ National Research Council, Nuclear Power: Technical and Institutional Options for the Future, pp. 1-14.
} 
Table 6. Power Plant Statistics for Canada, 1993

\begin{tabular}{|c|c|c|c|c|c|c|c|}
\hline Country & $\begin{array}{c}\text { Number of } \\
\text { Operable } \\
\text { Reactors }\end{array}$ & $\begin{array}{c}\text { Operable } \\
\text { Capacity } \\
(\mathrm{MWe})^{\mathrm{a}}\end{array}$ & $\begin{array}{l}\text { Number of } \\
\text { Reactors in } \\
\text { Construction }\end{array}$ & $\begin{array}{l}\text { Construction } \\
\text { Capacity } \\
(\mathrm{MWe})^{\mathrm{a}}\end{array}$ & $\begin{array}{c}1993 \\
\text { Capacity } \\
\text { Factor } \\
\text { (Percent) }\end{array}$ & $\begin{array}{c}\text { Amount of } \\
\text { Electricity } \\
\text { from Nuclear } \\
\text { Units in } 1993 \\
(T W h)^{b}\end{array}$ & $\begin{array}{c}1993 \\
\text { Percent } \\
\text { Nuclear } \\
\text { Share }^{c}\end{array}$ \\
\hline Canada .. & 22 & 15,755 & 0 & 0 & 70 & 88.6 & 17.3 \\
\hline
\end{tabular}

${ }^{\mathrm{a}} \mathrm{MWe}=$ Megawatt electric.

${ }^{\mathrm{b}} \mathrm{TWh}=$ Terawatthours.

${ }^{\mathrm{C}}$ Net electricity generated from nuclear power generating units as a percentage of net electricity generated from utilities and nonutilities.

Source: Table 1. 1993 Capacity Factor: Nucleonics Week (New York, McGraw-Hill) (February 10, 1994).

The higher level was largely due to a reduction in maintenance outages for the Darlington, Bruce, and Pickering nuclear stations.

In 1993, the Ontario province continued to suffer from a severe recession, which reduced electricity needs. ${ }^{17}$ As a result, $\mathrm{OH}$ is attempting to bring power demand and supply into balance by prematurely closing some plants. After reviewing an internal power planning study completed in January 1994, which showed declining energy sales over the past 4 years and forecast little or no growth in the foreseeable future, the $\mathrm{OH}$ board voted to reduce surplus generating capacity by almost 3,000 MWe-roughly 8 percent-over the next 3 years.

$\mathrm{OH}$ has nearly 30 GWe but seldom needs more than 23 GWe. ${ }^{18}$ Consequently, the utility plans to shut down two oil-fired plants at the Lennox power station, two coal-fired units at the Lambton station, and one nuclear unit at the Bruce station. However, Bruce 2, an 18-yearold, 848-MWe PHWR located near Tiverton, Ontario, will not be decommissioned; instead, the unit will be preserved in such a way that it can be brought back into service rather quickly if needed. These cost-cutting measures will hold 1995 rate increases to the general inflation rate of 1.4 percent and save the utility about $\$ 150$ million over the next 10 years. ${ }^{19}$ Because of Canada's large capacity reserve margins and decreasing electricity demand, EIA projects that nuclear capacity will fall from its current 15.8 GWe to 14.1 GWe by 2010 in the Low Case. The decline reflects the closing of the Bruce 2 nuclear unit in 1995 and Bruce 1 in 1998.

After predicting a $\$ 1$ billion loss for 1993, the financially strapped $\mathrm{OH}$ spent most of 1993 studying and implementing new measures that would reshape the company. ${ }^{20}$ In April 1993, the utility announced its intention to split into three distinct groups: (1) electricity, (2) energy services and environment, and (3) enterprise. Following the reorganization announcement, $\mathrm{OH}$ announced that its three nuclear stations would begin to operate as independent business entities, starting August 1, 1994. The restructuring is part of an intensive effort on $\mathrm{OH}^{\prime}$ s part to decrease debt and keep electricity costs down.

Because of OH's huge debt, the board was also considering shutting down the heavy water plant at its Bruce station, since enough heavy water has been stockpiled to fuel its reactors until 2010. However, a contract by Korea Electric Power Corporation (KEPCO) to buy heavy water to start up the Korean utility's newest CANDU reactors between 1996 and 1998 has kept the country's heavy water plant operating at half capacity. Six of the twelve stacks will remain open, producing about 300 tons of $\mathrm{D}_{2} \mathrm{O}$ (heavy water) a year. ${ }^{21}$

Although the design life of Canadian nuclear power plants is 30 years, the strategic goal is to achieve a minimum life of 40 years. The target life of 40 years has been threatened, however, by unforeseen problems with some of the larger critical components. Major problems have recently arisen with the steam generators and the pressure tubes, much like the problems experienced by U.S. utilities. To ensure that its nuclear units remain economically viable, $\mathrm{OH}$ has instituted a vigorous program for life management of steam generators at the Pickering and Bruce stations, where the degradation is most severe.

\footnotetext{
17“ Ontario Hydro Moved to Close Plants Seen Balancing Supply and Demand," Electric Utility Week (February 21, 1994 ), p. 12.

${ }^{18}$ National Research Council, Nuclear Power: Technical and Institutional Options for the Future, pp. 1-14.

${ }^{19}$ Nuexco, Nuexco Review, 1993 Annual (Denver, CO, 1993), p. 85.

${ }^{20}$ Nuexco, Nuexco Review, 1993 Annual (Denver, CO, 1993), p. 85.

${ }^{21}$ Nuexco, Nuexco Review, 1993 Annual (Denver, CO, 1993), p. 86.
} 


\section{Western Europe}

The Western Europe region comprises 10 countries with a total capacity of 122.7 GWe from 153 nuclear units (Table 7). The region accounts for 36 percent of the world's total commercial nuclear power capacity. France has the region's highest capacity $(59.0 \mathrm{GWe})$ and currently is the only country in the region with a robust nuclear program, primarily because it lacks indigenous energy resources and has therefore turned to nuclear energy as the primary source of its electricity supply. The difference between the High and Low Cases for Western Europe in 2000 reflects expectations about retirement schedules and the completion of units under construction in France. By 2010, nuclear capacity in Western Europe is projected to drop slightly, to 119.0 GWe in the Low Case, as more retirements are projected, but increase to 135.8 GWe in the High Case.

The nuclear industry's primary concern is to maintain a safe and reliable operation of existing plants and, possibly, to extend the operating lives of some nuclear power plants. In the Low Case, the region's nuclear capacity is projected to be 125.0 GWe in 2000-an annual growth rate of 0.3 percent. However, several units throughout the region are expected to retire by
2000, fifteen units (1.8 GWe) in the United Kingdom, most of which became operational in the mid-1960' $\mathrm{s}$. In addition, by the turn of the century, one unit is projected to retire from each of the following countries: France, Netherlands, Slovenia, and Spain.

Although many countries in Western Europe have been affected by economic recession, their governments are predicting increased electricity demand in the future, with natural gas as the source most likely to meet the increased demand. The recent economic slump has taken its toll in France, as total demand increased by only 0.5 percent in $1993 .{ }^{22}$ As a result, demand projections have been revised downward by Electricite de France (EdF), which now calls for electrical demand growth ranging from 1.2 to 2.2 percent a year. ${ }^{23} \mathrm{EdF}^{\prime} \mathrm{s}$ policy previously called for the construction start of one nuclear unit every 18 months. Recently, EdF's president announced that the company will not order any new generating capacity for its mainland market before the year 2000, including nuclear power plants. However, EdF will examine electricity supply and demand conditions every year to take into account any new element that might appear. But barring unexpected developments, the only new generating plant $\mathrm{EdF}$ might order would be for Corsica or France's oversieas territories. ${ }^{24}$

Table 7. Power Plant Statistics for the Western Europe Region, 1993

\begin{tabular}{|c|c|c|c|c|c|c|c|}
\hline Country & $\begin{array}{l}\text { Number of } \\
\text { Operable } \\
\text { Reactors }\end{array}$ & $\begin{array}{c}\text { Operable } \\
\text { Capacity } \\
(\mathrm{MWe})^{\mathrm{a}}\end{array}$ & $\begin{array}{c}\text { Number of } \\
\text { Reactors in } \\
\text { Construction }\end{array}$ & $\begin{array}{c}\text { Construction } \\
\text { Capacity } \\
(\mathrm{MWe})^{\mathrm{a}}\end{array}$ & $\begin{array}{c}1993 \\
\text { Capacity } \\
\text { Factor } \\
\text { (Percent) }\end{array}$ & $\begin{array}{c}\text { Amount of } \\
\text { Electricity } \\
\text { from Nuclear } \\
\text { Units in } 1993 \\
(T W h)^{b}\end{array}$ & $\begin{array}{c}1993 \\
\text { Percent: } \\
\text { Nuclear' } \\
\text { Share }^{c}\end{array}$ \\
\hline Belgium & 7 & 5,527 & 0 & 0 & 83 & 39.5 & 58.9 \\
\hline Finland & 4 & 2,310 & 0 & 0 & 93 & 18.8 & 32.4 \\
\hline Netherlands $\ldots \ldots \ldots \ldots$ & 2 & 504 & 0 & 0 & 86 & 3.7 & 5.1 \\
\hline Slovenia . . . . . . . . & 1 & 632 & 0 & 0 & 68 & 3.8 & 43.3 \\
\hline Spain .............. & 9 & 7,105 & 0 & 0 & 85 & 53.6 & 36.0 \\
\hline Sweden $\ldots \ldots \ldots \ldots \ldots$ & 12 & 10,002 & 0 & 0 & 62 & 58.9 & 42.0 \\
\hline Switzerland & 5 & 2,985 & 0 & 0 & 85 & $\quad 22.0$ & 37.9 \\
\hline
\end{tabular}

${ }^{a} \mathrm{MWe}=$ Megawatt electric.

${ }^{\mathrm{b}} \mathrm{TWh}=$ Terawatthours.

${ }^{\mathrm{C}}$ Net electricity generated from nuclear power generating units as a percentage of net electricity generated from utilities and nonutilities.

Source: Table 1. 1993 Capacity Factor: Nucleonics Week (New York, McGraw-Hill) (February 10, 1994).

\footnotetext{
${ }^{22}$ Energy Resources International 1994 Report, "Status and Prospects for Nuclear Power," pp. 3-13.

23"EDF Delays Order," Nucleonics Week (July 1, 1993), p. 17.

${ }^{24}$ Ann Maclachlan, "No More Nuclear Plant Orders for EdF Before End of Century," Nucleonics Week (June 23, 1994$)$, pp. 1, 14.
} 
After a heated debate, Finland's parliament voted to reject the proposal to build the country's fifth reactor. The Finnish industry and trade unions were disappointed because they felt that nuclear power was the cheapest option for meeting future electricity demand, in addition to the jobs that would have been provided at a time when Finland is suffering an 18-percent level of unemployment. ${ }^{25}$ The Energy Department of the Trade and Industry Ministry predicts that Finland will need an additional 2,000 MWe by 2000 and another 1,500 MWe by $2010 .^{26}$ The country has very little hydroelectricity, and Sweden has rejected building a natural gas pipeline from Norway through Sweden to Finland. Currently, Finland imports about 14 percent of the country's electricity, about half from Sweden and half from Russia. The Finnish government would like to reduce its dependence on these countries, given the political instability in Russia and Sweden's present plan to phase out its nuclear plants by 2010 .

Despite Germany's success with its nuclear plants, the country's perception of nuclear power remains pessimistic. In October 1993, the German energy consensus talks ended with no resolution over the country's nuclear future. The talks focused on demands formulated at the 1986 convention in Nuremberg, which called for the immediate phaseout of nuclear energy and diversion of funding to energy conservation and renewable energies. ${ }^{27}$ As a result, Germany's nuclear power program remains status quo, leaving plants to continue operation as long as physically possible.

As a result of its 1991 National Energy Plan (PEN), Spain's current moratorium on nuclear plant construction will continue until 2000 . Two reactors that were in advanced stages of construction have been eliminated from the EIA's construction pipeline (Appendix D). New environmental requirements of the PEN entail a 40-percent reduction in sulfur emissions from coal-fired power plants. The country has focused its attention on gas-fired power plants as its most viable alternative to coal, oil, and nuclear power.

The nine operating nuclear power plants in Spain produced 36 percent of the country's electricity in 1993 and had an overall capacity factor of 85 percent. In 1993, traces of boric acid were found on the outside of the vessel head of the Jose Cabrera nuclear reactor, which led to the discovery of a throughwall crack in the 153MWe PWR. The unit, one of Europe's earlier nuclear power reactors, has been operating for 26 years. A license renewal project had been started to extend the operating life of the plant, but the cracks in the vessel head could raise questions about the aging of primary pressure components. ${ }^{28}$

Like Spain, Switzerland is in its third year of a 10-year moratorium on nuclear construction. In addition, 1993 marked the first time in 18 years that electricity demand dropped. The drop, due primarily to the continued recession in the country, is expected to be temporary according to the Swiss Association of Electrical Utilities, which predict an annual growth rate in demand of 2 percent. ${ }^{29}$ Although no new nuclear plants can be built in the country, the government's energy plan calls for 10-percent upgrades for all five of the Swiss nuclear units. The plants provided 37.9 percent of the country's electrical generation in 1993.

Of the 35 operable units in the United Kingdom, 21 units have been operating for at least 19 years. Since only a handful of new nuclear plants have been ordered in Europe over the past 15 years, older reactors have become pivotal in maintaining the nuclear option.

The long-awaited nuclear review that will determine whether nuclear power has any future in the United Kingdom finally began on May 19, 1994. The idea of a review was originally announced in 1989, when Britain scrapped plans to privatize the nuclear component of the state electricity generation system. The government feared that nuclear's high cost and uncertain decommissioning and cleanup liabilities would discourage investors. ${ }^{30}$ To ensure that the question of new nuclear plant construction is on the agenda of the review, Nuclear Electric plc (NE) has submitted an application to the Department of Trade and Industry to build a third unit at its Sizewell nuclear power station. ${ }^{31}$

\section{Eastern Europe}

The 65 nuclear units in the Eastern Europe region had a total capacity of 43.5 GWe at year-end 1993. Russia and Ukraine accounted for three-quarters of the

\footnotetext{
${ }^{25}$ "Parliament Votes Against Building Fifth Power Reactor," Nuclear News (November 1993), pp. 51, 54.

${ }^{26}$ Nuexco, 1993 Annual Nuexco Review (Denver, CO, 1993), p. 58.

27"Energy Consensus Talks Collapse Over Nuclear Issues," Nuclear News (December 1993), pp. 61-62.

${ }^{28 \prime \prime}$ Vessel head penetration crack found at Jose Cabrera," Nuclear News (March 1994), p. 66.

${ }^{29}$ Nucleonics Week, July 22, 1993, p. 16.

${ }^{30}$ Nuexco, 1993 Annual Nuexco Review (Denver, CO, 1993), p. 82.

31 “U.K.'s Nuclear Electric Has Applied to Build Sizewell C," Nuclear News (November 1993), p. 19.
} 
capacity within the region. The situation in Eastern Europe looks similar to that of Western Europe. Since nuclear power is expensive, the recession that Eastern European countries are experiencing (as they shift to market economies) reinforces the low growth depicted in the Low Case projections.

At the end of 1993, there continued to be a great deal of uncertainty surrounding the continued operation of first- generation VVER-440 and RBMK model reactors in Eastern Europe. The possibility that some of these units will be retired early has been discussed among the different countries; however, due to the energy shortage in Eastern Europe, no country has implemented such a plan.

Russia currently has 29 operating plants with a total capacity of $19.8 \mathrm{GWe}$, providing 12.5 percent of the electricity produced in the country (Table 8). In 1993, Balakovo 4 went into commercial operation, the first new Russian reactor since 1990. Russia has 9 VVER1000 reactors, 16 RBMK's, and 4 first-generation VVER440 reactors. While Russia's nuclear energy plans are far from final, the country is implementing a program designed to upgrade the RBMK's to a level of safety acceptable for continued operation, despite the U.S.'s concern over lengthening the operation of these reactors. Due to Russia's extreme difficulties in raising capital, any additional capital that is obtained will be used toward the completion of the Kalinin 3 and Kursk 5 units.
By 2000, the region's Low Case nuclear capacity is projected to increase to $47.9 \mathrm{GWe}$-an annual growth rate of 1.4 percent-as units that are in advanced stages of construction are completed in Russia and in Ukraine. By 2010, nuclear capacity in Eastern Europe is projected to decrease slightly in the Low Case, compared with an addition of about 18 GWe in the High Case.

Over the projection period, Russia's nuclear capacity is expected to remain fairly level in both the High and Low Cases. Although new units are projected to come on-line, their contribution will be offset by retirements. By 2010, nuclear capacity is projected to be 17.4 GWe in the Low Case and 20.2 GWe in the High Case.

Ukraine is highly dependent on energy imports from Russia, which demands hard currency payments. The country's 15 operable plants have a capacity of 12.7 GWe and provided 32.9 percent of the electricity supply in 1993. Capacity is projected to grow at annual rates of 1.6 and 0.7 percent in the High and Low Cases, respectively. On October 21, 1993, the Ukrainian parliament lifted the moratorium on commissioning new nuclear units, and reversed its earlier decision to permaneritly shut down the Chernobyl 1 and 3 units by the end. of the year. The two units are RBMK's with design lives of 30 years. Having lifted the moratorium, the country will now concentrate on completing three VVER-1000 nuclear units (Zaporozhe-6, Khmelnitski-2, and Rovno4). Given the country's need for energy, there is a possibility that the turbine hall of Chernobyl 2, which

Table 8. Power Plant Statistics for the Eastern Europe Region, 1993

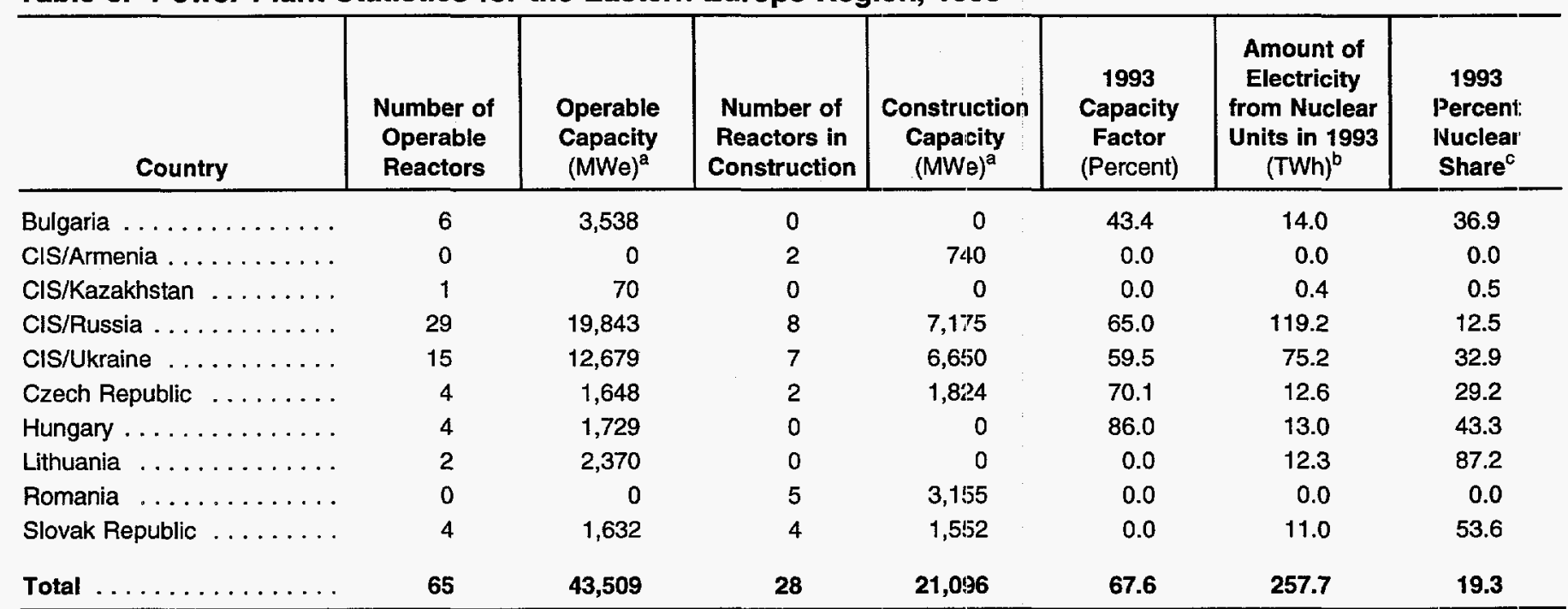

${ }^{\text {a } M W e}=$ Megawatt electric.

${ }^{\mathrm{b}} \mathrm{TWh}=$ Terawatthours.

'Net electricity generated from nuclear power generating units as a percentage of net electricity generated from utilities and nonutilities.

Source: Table 1. 1993 Capacity Factor: Nucleonics Week (New York, McGraw-Hill) (February 10, 1994). 
was damaged in a fire in October 1991, could be repaired and the plant brought back on-line at 50percent power. Once the new plants are brought online, the Chernobyl station could then be retired.

Lithuania, which declared its independence mid-1991, has two of the largest nuclear units in Eastern Europe, and at 87.2 percent, produced the highest share of electricity from nuclear power. In November 1993, the Lithuanian government approved plans to store spent fuel on site from its two RBMK units, Ignalina 1 and 2. The spent fuel will be put into cast iron transport/storage casks and housed in the partially constructed third reactor located about 1 kilometer from units 1 and 2. The Chernobyl accident in 1986 created opposition to nuclear power in Lithuania and led to questions regarding the safety of the planned third and fourth units, which ultimately led to their cancellation.

Romania's nuclear power construction program began in 1979 with plans to construct a multi-reactor facility at Cernavoda. Because the country is rich in uranium deposits, officials decided to implement CANDU technology, which uses a natural uranium fuel. This decision will enabled Romania to avoid becoming dependent on foreign sources for fuel enrichment. Romanian officials believe that nuclear generating capacity is needed because the country faces power shortages and is suffering from pollution associated with fossil-fuel generation. ${ }^{32}$ In 1989 , the five plants at Cernavoda were still unfinished when the Ceausescu government was overthrown. The new Romanian government invited the IAEA to inspect progress and to assist in the completion of the units.

With the help of Canada's Export Development Corporation, which has authorized $\$ 315$ million toward the completion of Cernavoda 1, fuel loading is expected in 1994 and grid connection in 1995. Romania, Canada, Italy, and France are currently discussing ways to complete Cernavoda 2. Some of the civil construction work has been done and many components are on site. At present, the partners are considering a buildoperate-transfer of the unit. The $\$ 1$ billion project would be financed by loans arranged by each partner with repayment financed by selling electricity to the surrounding countries-Ukraine, Bulgaria, Greece, Italy, and Austria. However, the Romanian electricity grid would have to be upgraded and coordinated with countries wanting to buy electricity.
In 1988, an earthquake caused catastrophic damage in Armenia. Although the Armenian nuclear station was not damaged, concerns were raised about its ability to survive a similar earthquake if it were centered closer to Yerevan, where the station is located. Because of the earthquake, the plant was closed in 1989.

Following the breakup of the former Soviet Union, the Armenian government instituted daily brownouts to conserve energy. As a result, schools canceled classes, businesses were plagued by insufficient power supplies and, factory production ceased.

Convinced that the operation of the nuclear plant is necessary to provide additional energy to the country, the Armenian parliament voted in 1993 to cancel its 1992 resolution to hold a public referendum on the question of resuming operation of the Armenia 1 and 2 reactors. A summary inspection by Framatome indicated that the units were in fair shape, but a comprehensive inspection has yet to be completed. Framatome believes the work needed could possibly be accomplished in 18 months; however, it will probably take much longer since only modest aid is expected from Western industry and governments. Financing is the most controversial element in the assessment of restarting Armenia 1 and Armenia 2. In April 1993, the Armenian parliament allocated about $\$ 4$ million to begin work on the reactors. A hole was cut into one of the steam generators in the Armenia 1 unit; therefore, Armenia 2 is most likely to be restored first. Preliminary cost estimates to restart the plant range from $\$ 100$ to $\$ 500$ million. The country hopes to have Armenia 2 on-line by late 1994 or early 1995; however, EIA does not expect the unit to become operable until $2000 .^{33} \mathrm{By}$ 2010, Armenia's capacity is projected to be 0.4 and 0.7 GWe, in the Low and High Case, respectively.

Most of Eastern Europe's gains in nuclear capacity (High Case) will come from the smaller countries, such as Armenia, the Czech Republic, and Hungary. The Czech Republic is projected to more than double its current capacity by 2010 . The country's Temelin station is due to be completed before 2000-adding 1.8 GWe in the High Case to its current 1.6 GWe.

\section{Far East}

In 1993, the Far East region accounted for 15 percent of total world nuclear capacity. Most of the countries are

\footnotetext{
${ }^{32}$ Gayle Research Inc., "Nuclear Power Plants Worldwide," (Detroit, MI, 1993), pp. 207-209.

${ }^{33}$ The Armenia 1 and 2 reactors are included in the construction pipeline; however, there are no data indicating how much work is needed to complete and restart the units. EIA has placed these units in the 76 to 100 percent complete category.
} 
mountainous and isolated, lack natural resources, and depend on imports from other countries to fuel their economies. The oil shocks of the mid-1970's and early 1980 's led these countries to nuclear power as a means to spur economic growth. As a result, China, Japan, and Taiwan are rapidly developing economically despite their lack of domestic resources.

The region's 65 operable units have a total capacity of 51.3 GWe (Table 9), with a projected additional capacity of 22.8 GWe in the Low Case and 34.4 GWe in the High Case by 2010 -annual growth rates of 2.2 and 3.1 percent, respectively. Five units began operation-four units located in Japan (Genkai 3, Hamaoka 4, Kashiwazaki Kariwa 4, and Shika 1) and one unit in China (Guangdong 1). As of December 31, 1993, the region's construction pipeline comprised of 34 units had a total capacity of $30.7 \mathrm{GWe}$, with Japan accounting for the largest share.

With China's rapid population and economic growth, the government hopes that nuclear power will provide the electricity that the region desperately needs. In the long term, the country is focusing on developing a nuclear infrastructure, with the aim of developing an advanced reactor by the 21st century. China has developed and is currently marketing a 300-MWe PWR and a $600-M W e$ PWR, which it plans to export to developing nations.

China, which had no nuclear power plants until 1991, is planning to connect a third nuclear plant in 1994.
Guangdong 1, China's second nuclear unit, was connected to the grid in September 1993. Seventy percent of the reactor's output will be distributed to Hong Kong and the remaining 30 percent to Guangdong. ${ }^{34}$ Guangdong 2, one of three units in the construction pipeline, is expected to begin operation in 1994. Qinshan 2 and Qinshan 3 are projected to begin commercial operation in 2001 and 2002 (High Case), respectively. The additional reactors will increase the country's electricity generation, and by 2010, China is projected to have between $3.3 \mathrm{GWe}$ and $5.3 \mathrm{GWe}-\mathrm{a} 4.5$ to 6.2 percent share of the total capacity in the Far East region.

Much of the increase in the world capacity projection for 2010, in the Low and High Cases, comes from the Far East region. Although projected capacity growth in the Far East region far surpasses that in any other region, opposition to nuclear power among Far East citizens continues to grow. By 2000, nuclear capacity in the Far East is projected to reach 60.3 GWe in the Low Case, with Japan accounting for about 72 percent of the region's total.

Japan has 4.8 operable reactors. The four units that were connected to the grid in 1993 added 3.8 GWe of capacity, bringing Japan's total installed nuclear capacity to 38.0 GWe. Tepco, Japan's largest utility, which provides electricity to the most densely populated regions, accounted for the majority of the country's total nuclear capacity. The country generated 246.3 TWh of electricity, with an average capacity factor

Table 9. Power Plant Statistics for the Far East Region, 1993



${ }^{a} \mathrm{MWe}=$ Megawatt electric.

${ }^{\mathrm{b}} \mathrm{TWh}=$ Terawatthours.

${ }^{c}$ Net electricity generated from nuclear power generating units as a percentage of net electricity generated from utilities and nonutilities.

Note: -- Not available.

Source: Table 1. 1993 Capacity Factor: Nucleonics Week (New York, McGraw-Hill) (February 10, 1994).

\footnotetext{
${ }^{34}$ Kenten D. Lindberg, “The People's Republic of China: Fueling Tremendous Growth with Nuclear Power," Nuexco Review (September 1993), pp. 24-32.
} 
of 73 percent in 1993, an increase of 14 percent over 1992. Japan's ambitious nuclear power program was established with the goal of achieving energy independence. The country's goal, as stated in its Atomic Basic Law, is "to secure energy resources in the future . . . and thereby contribute to the welfare of mankind and to the elevation of the national living standard." Japan's long-term nuclear power program includes the construction and operation of reprocessing and recycling facilities in order to reduce its dependence on foreign energy resources. It is the first country in the Far East to implement a commercial-scale uranium enrichment plant. However, problems of plant siting could constitute a major hindrance to Japan's nuclear program.

Opposition to new reactors continues to grow in Japan's coastal areas. To spur public confidence, the Ministry of International Trade and Industry (MITI) has discounted electric bills to citizens living near nuclear power plants or construction sites. MITI regulates utility rates, licenses new reactors, monitors safety, and acts as an impartial arbiter between government and industry.

In early 1993, a storm of criticism arose in Japan when a ton of plutonium was transported from France to be used in Japan's fast breeder reactors. ${ }^{36}$ Fast breeder reactors are designed to produce more fuel (plutonium) than they consume and at the same time produce electricity. Environmental groups are concerned about shipping such a large quantity of plutonium, which requires increased safety precautions in case of accidents or potential terrorist activity. In addition, the groups questioned the need for the plutonium fueled power plant when uranium is abundant and inexpensive. The Japanese began breeder research in 1967, when uranium supplies were expected to last only 50 years. However, when the Monju reactor was planned, the system seemed perfect for a country with limited energy resources which imported virtually all its energy supplies. In 1980, the country began construction on the Monju plant and achieved initial criticality on April 5, 1994.

The IAEA wanted to inspect the fuel rods from North Korea's Yongbyon research reactor to determine whether spent fuel had been removed to produce plutonium, which is used to manufacture nuclear weapons. Before the IAEA could inspect the reactor core, North Korea had removed more than half of the fuel rods and refueled the reactor in record time. The rapid unloading of the reactor's core prevented the IAEA from ascertaining the level of the fuel's irradiation. October 1994, the U.S. and North Korea met to attempt to resolve worries about North Korea's nuclear program (believed to produce nuclear weapons). Concessions have been made between the two countries; however, the agreement has not been signed as yet.

North Korea currently has two units in the construction pipeline, Nyongbyon (50 MWe) and Taechon (200 MWe), that are expected to become operable in 1996 and 2001, respectively. There are currently no units in commercial operation.

South Korea has experienced tremendous economic growth since 1962. Its long-term development plan calls for nine additional units by 2004, and seven units are currently in the construction pipeline. Since the mid1980 's, nuclear power has played a significant role in electricity production. The country has a Cooperation Agreement with Argentina, Belgium, Canada, England, France, Italy, Japan, China, and the United States for technological development. ${ }^{37}$

Korea Electric Power Company's nine operating reactors, eight PWR's and one PHWR, have a total net capacity of 7,220 MWe, which accounted for 40.3 percent of the country's electricity. Seven units in the construction pipeline have a total net capacity of 5.8 GWe. Yonggwang 3 and Yonggwang 4 are projected to be connected to the grid in 1995 and 1996, respectively, in the High Case. Once connected to the grid, the two units will add 1.9 GWe. The steadily increasing nuclear generating capacity is projected to rise to $16.1 \mathrm{GWe}$ by 2010 in the High Case.

Taiwan's three nuclear power stations consist of four BWR's (3.1 GWe) and two PWR's (1.8 GWE), with a total capacity of 4.9 GWe. Taiwan has one nuclear power station, Yenliao, also known as the Lungmen project, in the construction pipeline. The Lungmen project consists of two 900-MWe PWR's which are planned to be built at Yenliao in northern Taiwan. The project, originally planned for 1982, was postponed and revived again in 1992, at which time groundwork was done for the plant. Bids have been submitted for the construction of the two units, but a vendor has not been selected. With the completion of the Lungmen project, the country's capacity is projected to reach 6.7 GWe by 2005.

\footnotetext{
${ }^{35}$ Marc L. Williams, "Japanese Electric Utility Uranium Procurement Practices," Nuexco Review (April 1994), p. 21.

${ }^{36}$ T.R. Reid, "Reactor Start-up Fuels Japan's Energy Plant," Washington Post (April 6, 1994).

${ }^{37}$ Gayle Research Inc., "Nuclear Power Plants Worldwide," pp. 189-201.
} 
Taiwan began its nuclear power program in the 1970's, but environmental concerns, the Chernobyl accident, and the fire at Taiwan's own Maanshan plant in 1985 shattered public confidence in the technology. Since then, opposition to the construction of another nuclear power plant has been high. On May 29, 1993, demonstrators marched in Taipei to protest the construction of any additional nuclear power plants. Environmentalists carried toy windmills to suggest other options to generate electricity. Nevertheless, Taiwan's government is convinced that an additional nuclear power plant is needed to keep pace with the country's future demand for electricity.

The island of Taiwan has 57 power plants. Nuclear power accounts for about 34 percent of electricity generation, coal 34 percent, and diesel fuel 25 percent. $^{38}$ Taipower is planning to develop more hydropower and natural gas plants to meet the country's immediate electricity demand.

In the Philippines, BNPP (formally PNPP-1) will be the country's first nuclear reactor when it is completed. Projected to become operable in 1995 (High Case), it is the sole reactor in the construction pipeline. The 620MWe PWR ordered in 1974 has been in the midst of legal and political disputes. Work began in 1976 and was halted in 1986 for safety and environmental reasons. Once the unit becomes operable, it will help alleviate the country's electricity shortage. Some areas experience shortages of electricity for as Iong as 10 hours a day, forcing businesses into a 4-day work week. The completion and eventual operation of the nuclear power plant would reduce the country's dependence on imported oil. However, President Ramos has stated that he does not want the unit to be operated, at least not as a nuclear power plant. Conversion of the unit to burn coal or natural gas is being considered.

\section{Other}

Accounting for 2 percent of the world's total nuclear capacity, the "Other" regional category is a mix of third-world countries; Argentina, Brazil, Cuba, India, Mexico, Pakistan, and South Africa. India is considered to be the most advanced in terms of installed commercial nuclear capacity. There are 16 operable units in the region and 15 units in the construction pipeline, totaling 5.8 GWe and 7.1 GWe, respectively (Table 10).

Argentina's two units accounted for the greatest percent of total electricity generated in the country at 14 percent. Atucha 1 and Embalse generated 7.2 TW/h of electricity in 1993. The country currently has only one reactor, Atucha 2, in the construction pipeline, but as in all the countries listed in the "Other" category, construction has been delayed because of finaning problems. The Argentine government has considered privatizing all three units, but progress in that direction is slow.

Table 10. Power Plant Statistics for the Other Region, 1993

\begin{tabular}{|c|c|c|c|c|c|c|c|}
\hline Country & $\begin{array}{c}\text { Number of } \\
\text { Operable } \\
\text { Reactors }\end{array}$ & $\begin{array}{c}\text { Operable } \\
\text { Capacity } \\
(\mathrm{MWe})^{\mathrm{a}}\end{array}$ & $\begin{array}{l}\text { Number of } \\
\text { Reactors in } \\
\text { Construction }\end{array}$ & $\begin{array}{l}\text { Construction } \\
\text { Capacity } \\
(\mathrm{MVVe})^{\mathrm{a}}\end{array}$ & $\begin{array}{c}1993 \\
\text { Capacity } \\
\text { Factor } \\
\text { (Percent) }\end{array}$ & $\begin{array}{c}\text { Amount of } \\
\text { Electricity } \\
\text { from Nuclear } \\
\text { Units in } 1993 \\
(T W h)^{b}\end{array}$ & $\begin{array}{c}1993 \\
\text { Percenit } \\
\text { Nuclear }^{\text {Share }}\end{array}$ \\
\hline Argentina & 2 & 935 & 1 & 692 & 87 & 7.2 & 14.2 \\
\hline Brazil & 1 & 626 & 2 & 2,474 & 8 & 0.4 & 0.2 \\
\hline Mexico ...... & 1 & 654 & 1 & 654 & 83 & 3.7 & 3.0 \\
\hline Pakistan . . . . . . . . . & 1 & 125 & 1 & 300 & 34 & 0.4 & 0.9 \\
\hline South Africa $\ldots \ldots \ldots \ldots$ & 2 & 1,842 & 0 & 0 & 46 & 7.2 & 4.5 \\
\hline Total & 16 & 5,775 & 15 & 7,106 & 48 & 24.3 & 2.8 \\
\hline
\end{tabular}

${ }^{a} \mathrm{MWe}=$ Megawatt electric.

${ }^{\mathrm{b}} \mathrm{TWh}=$ Terawatthours.

${ }^{\complement}$ Net electricity generated from nuclear power generating units as a percentage of net electricity generated from utilities and nonutilities.

Source: Table 1. 1993 Capacity Factor: Nucleonics Week (New York, McGraw-Hill) (February 10, 1994).

${ }^{38}$ Virginia Sheng, "Villagers Oppose Nuclear Plant, but Construction Continues," The Free China Journal (May 27, 1994$)$, j. 2. 
Located on Itaorna Beach, 130 kilometers from Rio de Janeiro, Angra 1, Brazil's sole nuclear unit, was connected to the electrical grid in 1982. The power produced from the station is integrated into the grid through two $500-\mathrm{kV}$ transmission lines. ${ }^{39}$ Construction was halted on Angra 2 and 3 in 1988, due to a lack of domestic funds and refusal of the World Bank to lend additional money to Brazil's electricity sector. As a result of delays in licensing procedures, organizational changes, and severe financial problems, the units are not projected to be connected to the grid before 1998. Angra 3, which is 42 percent complete, is likely to be canceled.

India's aggressive nuclear program uses heavy-water technology. The country also plans to export 100 metric tons of heavy water to South Korea for use in its Wolsong nuclear units. India's total installed nuclear power capacity at year-end 1993 was $1.6 \mathrm{GWe}$, consisting of seven PHWR's and two BWR's. India entered the nuclear arena in 1969 with Tarapur 1 and 2 built by General Electric. India's most recent unit, Kakrapar 1, was connected to the grid in 1992 and achieved commercial operation in 1993. India has not signed the Nuclear Non-Proliferation Treaty but has offered to put Kakrapar 2 under IAEA safeguards to prove that it has no ill intention for the use of reprocessed fuel.
Currently, the country has eight units in the construction pipeline, with a total projected capacity of 2.2 GWe. The units are projected to be connected to the electrical grid between 1998 and 2005 in the High Case. Kakrapar 2, which is 80 percent complete, is expected to be connected to the grid in 1995.

Mexico's sole commercial nuclear reactor, Laguna Verde, generated 3.7 TWh of electricity in 1993, which accounted for 3 percent of Mexico's total electricity production. The unit achieved a capacity factor of 83 percent. Laguna Verde 2, its twin unit, is expected to be connected to the electrical grid in 1994 in the High Case. The unit is 95 percent complete and is the only reactor in Mexico's construction pipeline.

Although the "other" countries have relatively small nuclear power programs in contrast to the major regions, some countries are cautiously optimistic about nuclear power. Capacity is projected to increase almost 50-percent by 2010 , totaling $10.8 \mathrm{GWe}$ in the Low Case, and to more than double to 15.5 GWe in the High Case. For the most part, nuclear materials and facilities in these countries are not under IAEA safeguards. However, India has offered to put its Kakrapar 2 unit, which is projected to become operable in 1995 (High Case), under IAEA safeguards.

${ }^{39}$ Gayle Research, Inc., Nuclear Power Plants Worldwide, pp. 19-22. 



\section{Nuclear Fuel Cycle and Uranium Market Developments}

This chapter provides information on selected aspects of the nuclear fuel cycle and contains a discussion of developments in the uranium market. It includes worldwide projections of requirements for uranium and enrichment services, along with projections of spent fuel discharges through 2010. Also presented are projections through 2005 of uranium prices, imports, inventories, and uranium production in the United States. Nuclear fuel requirements are based on projections of nuclear capacity (discussed in Chapter 2) and expected fuel cycle operating characteristics. The International Nuclear Model PC Version (PCINM), discussed in Appendix B, was used to calculate these requirements. Discussed below are the nuclear fuel design and management parameters used in the PCINM to estimate future requirements.

\section{Nuclear Fuel Requirements}

\section{Nuclear Fuel Management Parameters}

When available, historical data on individual reactor capacity factors were used to calculate requirements; otherwise historical data on regional average capacity factors were used. This procedure resulted in an estimated worldwide average capacity factor of 70 percent in 1994, increasing to 73 percent by 2010 . Last year's report presented a more optimistic view that capacity factors would increase to 75- to 80-percent by 2010 . However, due to a high degree of uncertainty in the performance of the nuclear industry, a more conservative estimate of future capacity factors was assumed this year. It is important to note that because uranium requirements are proportional to capacity factors (i.e., a 5-percent increase in the average capacity factor for the industry will increase industry-wide uranium requirements by 5 percent), the uncertainty associated with future capacity factors ripples through to uranium requirements. If the capacity factors used in the projections are lower than those actually achieved, projected requirements will also be lower than actual requirements.

Over the past several years, nuclear fuel discharge burnup levels for light water reactors (LWR's) have been increasing, and this trend is expected to continue in the future. Discharge burnup levels for pressurizedwater reactors (PWR's) have gone from about 31,000 megawattdays thermal per metric ton of uranium (MWD/MTU) in 1980 to $39,000 \mathrm{MWD} / \mathrm{MTU}$ in $1992 .^{40}$ For boiling-water reactors (BWR's), average discharge burnup has increased from about 23,000 MWD/MTU in 1980 to $29,000 \mathrm{MWD} / \mathrm{MTU}$ in 1992. One of the main driving forces toward a higher burnup has been the economic advantage to be gained by the utilities. Studies have shown that specific uranium consumption (i.e., natural uranium used per megawatthour of electricity produced) is reduced at higher fuel burnup levels. ${ }^{41}$ Burnup extension could save more than 15 percent in specific uranium consumption when implemented with unchanged cycle length. Spent fuel discharges are also reduced with higher burnup. On the other hand, increasing burnup commonly has little effect on the consumption of separative work units (SWU) per unit of energy generated, and can be increased or decreased depending on the length of the cycle and the burnup level. The design levels for discharge fuel burnup levels used to project fuel requirements are assumed to range from 33,000 MWD/MTU to $43,000 \mathrm{MWD} / \mathrm{MTU}$ for BWR's, and from 42,000 to $55,000 \mathrm{MWD} / \mathrm{MTU}$ for PWR's. (See Appendix $B$ for more detailed information. $)^{42}$

Both uranium and enrichment requirements are influenced by the tails assay used for enrichment. Tails assay refers to the amount of the U-235 isotope in the natural uranium that is lost or wasted during the enrichment process. As an example of its effect, an increase of the tails assay from 0.25 percent to 0.30 percent increases natural uranium requirements by 9

\footnotetext{
${ }^{40}$ Energy Information Administration, Spent Nuclear Fuel Discharges from U.S. Reactors 1992, SR/CNEAF/(94-01) (Washington DC, May 1994), p. 20.

${ }^{41}$ International Atomic Energy Agency, Water Reactor Fuel Extended Burnup Study, Technical Reports Series No. 343 (Vienna, 1992), p. 44.

${ }^{42}$ Design discharge burnup is usually higher than actual discharged burnup.
} 
percent. For the United States, a 0.30-percent tails assay is assumed for the entire projection period, 1994 through 2010. For all other countries, a 0.28-percent tails assay is used. These estimates are based on a review of the literature and conversations with officials working in the enrichment industry. ${ }^{43}$ An optimal tails assay that minimizes the cost of enriched uranium by taking into consideration the tradeoff between the costs of natural uranium and separative work units cannot be calculated due to the lack of projections for uranium and SWU prices.

\section{Uranium Requirements}

Uranium requirements are defined as the amount of uranium needed to fuel reactors. These requirements do not include the purchase of uranium to be held as inventory for later use. Cumulative requirements for the world from 1994 through 2010 are projected to total
2.5 to 2.7 billion pounds of natural uranium (Table 11). ${ }^{44}$ They fluctuate between about 128 to 178 million pounds $\mathrm{U}_{3} \mathrm{O}_{8}$ per year from 1994 through 2010, with the average at 144 million pounds $\mathrm{U}_{3} \mathrm{O}_{8}$ for the Low Case and 155 million pounds for the High Case (Table 12). ${ }^{45}$ For the Low Case, annual uranium requirements start to decrease in 2007, reflecting the projected decrease in nuclear capacity. On the other hand, a general increase in uranium requirements for the High Case reflects the modest growth in projected nuclear capacity through 2010.

For the Low Case, Western Europe accounts for 31 percent of total uranium requirements from 1994 through 2010, followed closely by the United States at 30 percent (Figure 2). The Far East and Eastern Europe account for 17 percent and 16 percent, respectively, of the uranium requirements, with Canada and other countries accounting for the remaining amount. The

Table 11. Projected Cumulative Uranium Requirements for World Nuclear Power Plants, 1994-2010 (Million Pounds $\mathrm{U}_{3} \mathrm{O}_{8}$ )

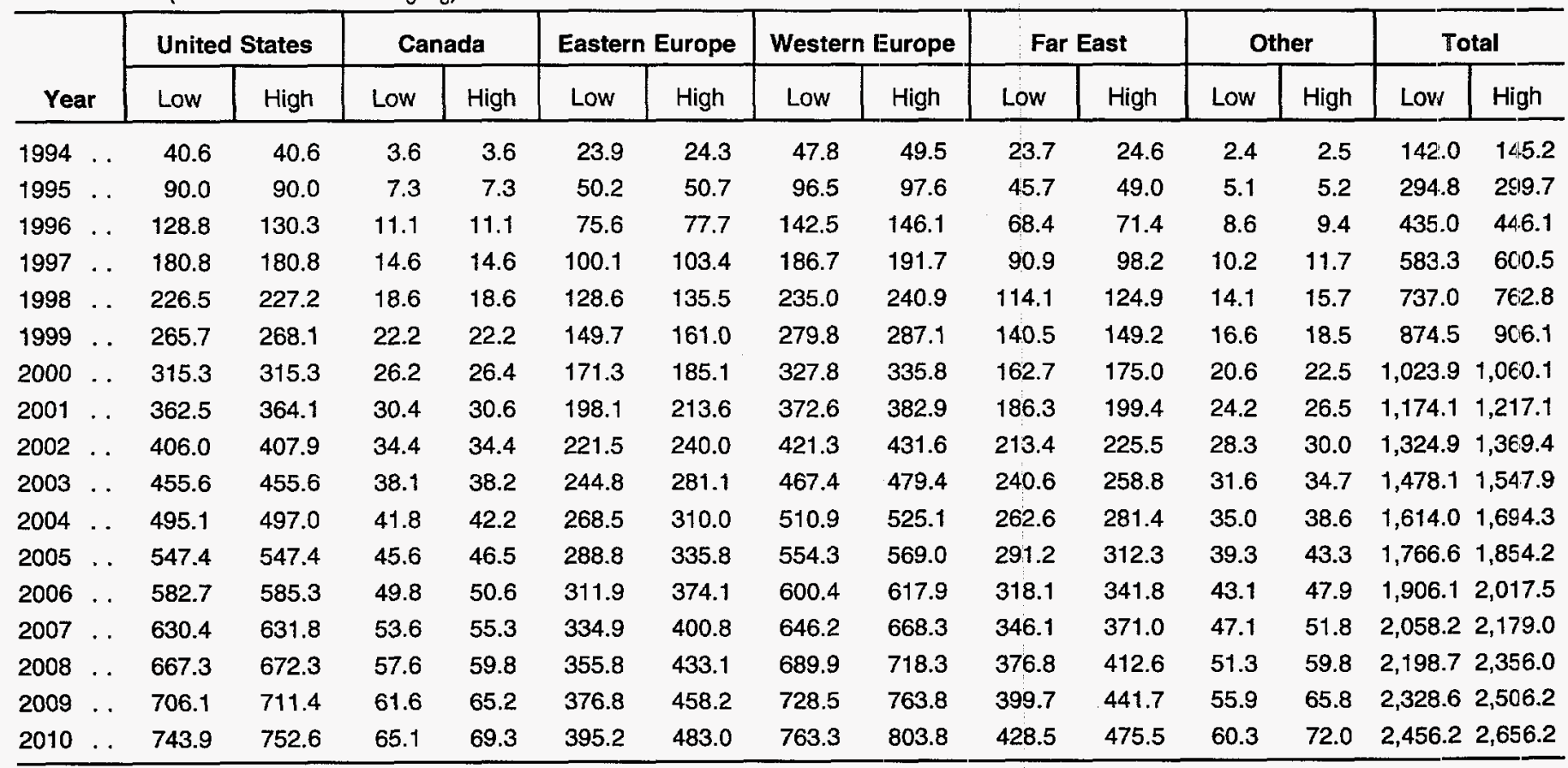

Note: Totals may not equal sum of components due to independent rounding.

Source: Energy Information Administration, Office of Coal, Nuclear, Electric and Alternate Fuels, International Nuclear Model, File INM94.WK3.

\footnotetext{
${ }^{43}$ Energy Resources International, 1994 Nuclear Fuel Cycle Supply and Price Report, and NUEXCO, Nuclear Fuel Market Analyses and Price Trend Projections 1993, were examined to help establish the appropriate tails assay. Also, Mr. Howard Huie, Office of Uranium Programs, U.S. Department of Energy, was contacted to obtain information on the current tails assay being used in the industry.

${ }^{44}$ In last year's report, worldwide uranium requirements were projected to range from 2.6 to 2.9 billion pounds $\mathrm{U}_{3} \mathrm{O}_{8}$ through 2010 . The difference is due to a lower capacity projection for the High Case in this year's report compared to last year, and the assumption in this year's report that worldwide average capacity factors will not increase beyond 73 percent through 2010.

${ }^{45}$ The fluctuation in annual requirements is caused, in part, by reactor refueling outages lasting longer than 1 year.
} 
Table 12. Projected Annual Uranium Requirements for World Nuclear Power Plants, 1994-2010 (Million Pounds $\mathrm{U}_{3} \mathrm{O}_{8}$ )

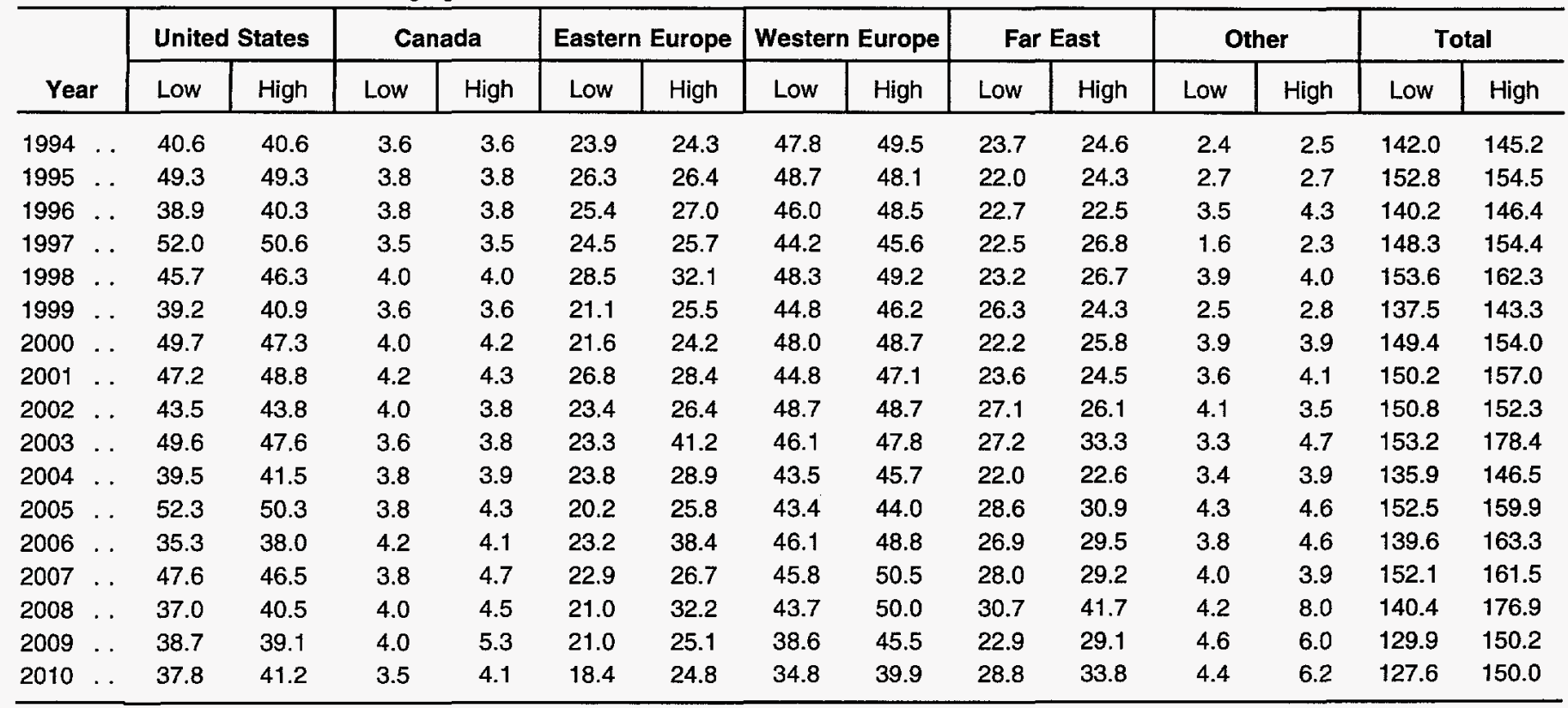

Note: Totals may not equal sum of components due to independent rounding.

Source: Energy Information Administration, Office of Coal, Nuclear, Electric and Alternate Fuels, International Nuclear Model, File INM94.WK3.

Figure 2. Total Uranium Requirements by Region, 1994-2010, Low Case Projections

(Million Pounds $\mathrm{U}_{3} \mathrm{O}_{8}$ Equivalent)

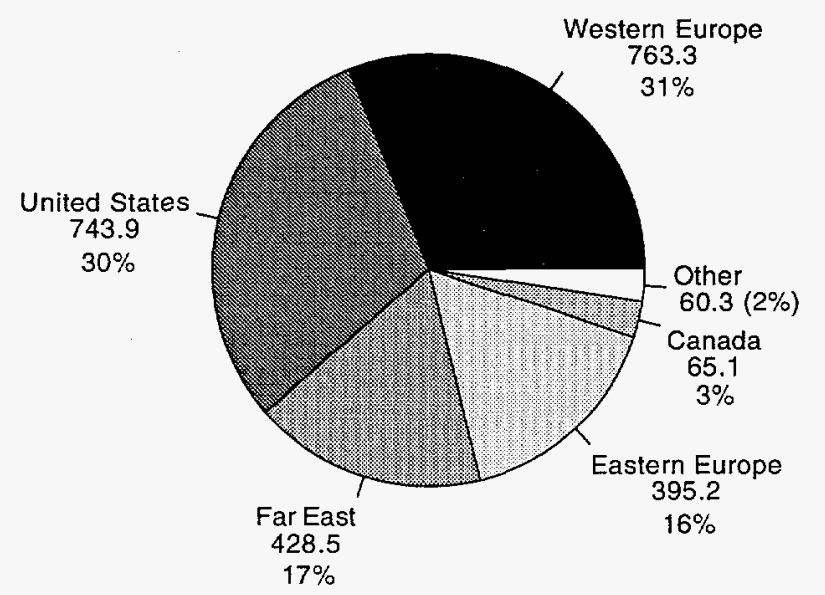

Source: Energy Information Administration, Office of Coal, Nuclear, Electric and Alternate Fuels, International Nuclear Model, File INM94.WK3.
High Case has a similar regional distribution for uranium requirements.

Some of the uranium requirements discussed above will be displaced by the use of plutonium, which is combined with uranium to form a mixed-oxide fuel (MOX). Four countries in Western Europe have MOX fuel loading programs for some of their LWR's. ${ }^{46}$ Germany and France are currently using MOX fuel; Belgium and Switzerland have plans to do so. Japan also intends to use MOX fuel in a large-scale demonstration effort, possibly in 1995, leading to four reactors using MOX by 1999, and an even larger number after 2000.

For the projections developed in this report, it is estimated that 14 reactors in Western Europe will be using MOX fuel in 1994, increasing to 36 reactors by 2010. Twelve reactors in Japan are projected to be using MOX fuel by 2010 . Under the most optimistic scenario concerning the use of MOX fuel, total requirements from 1994 through 2010 in Western Europe and the Far East can be reduced by 9.1 percent, equivalent to about 109 million pounds $\mathrm{U}_{3} \mathrm{O}_{8}$ (Table 13). This projection assumes that all operators of reactors applying for a

\footnotetext{
${ }^{46}$ Information on the use of MOX fuel was obtained from the Nuclear Assurance Corporation, "Nuclear Fuel Management Seminar" (Norcross, Georgia, November 1993), and a paper written by Marilyn Meigs, Disposition of Weapons Plutonium: Reuse or Vitrify, Nuclear Fuel Cycle Conference, sponsored by the Nuclear Energy Institute (Boston, Massachusetts, March 20-23, 1993).
} 
Table 13. Projected Annual Uranium Requirements for Western Europe and the Far East With and Without MOX Fuel, Low Case, 1994-2010

(Million Pounds $\mathrm{U}_{3} \mathrm{O}_{8}$ )

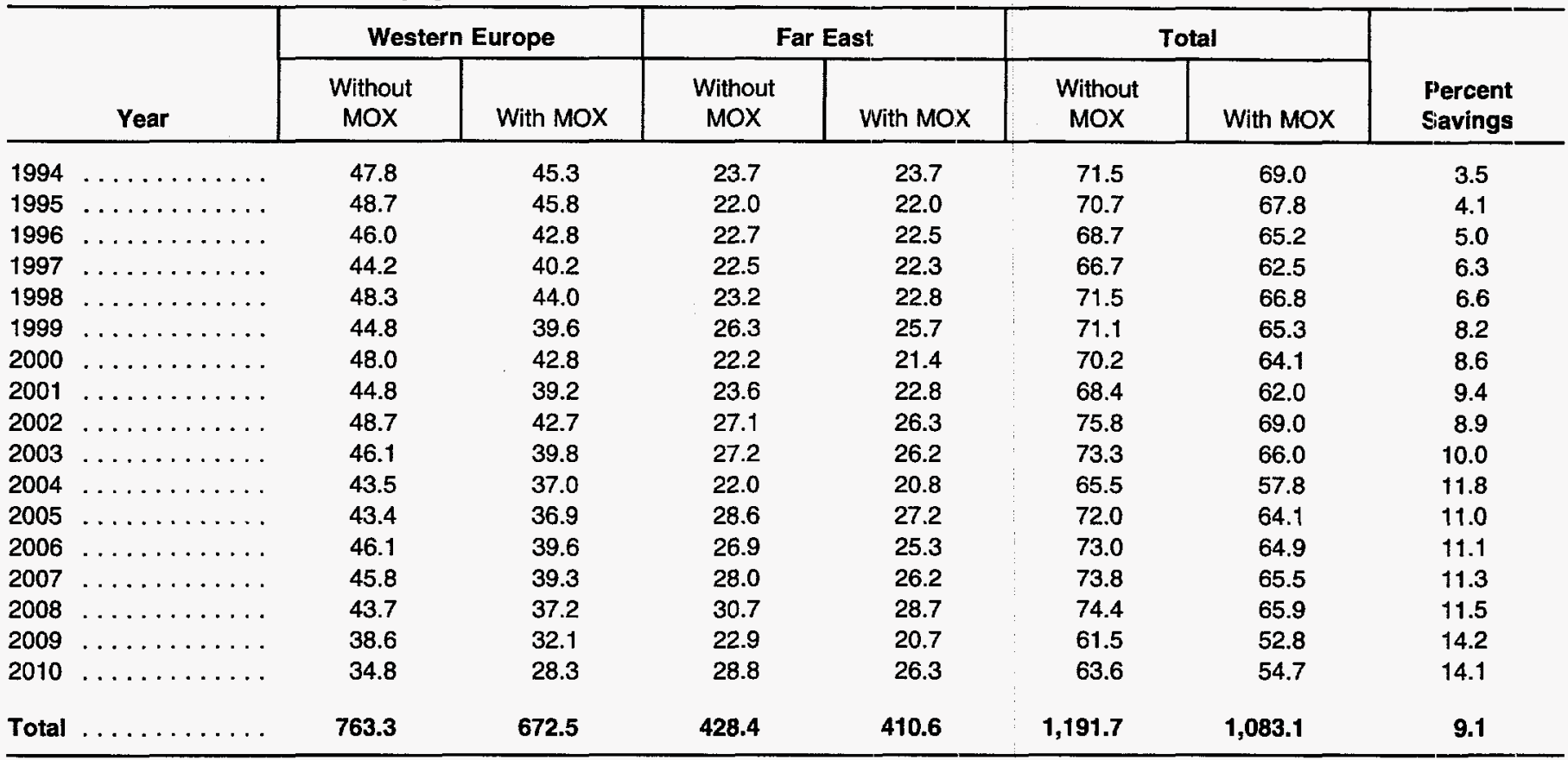

Note: Totals may not equal sum of components due to independent rounding.

Source: Energy Information Administration, Office of Coal, Nuclear, Electric and Alternate Fuels, International Nuclear Model, File INM94.WK3.

MOX licenses will receive them, that all will choose to use MOX fuel in about 30 percent of the reactor's core, and that once the reactor retires, it will be replaced with another reactor using MOX fuel. Even though reactor operators have licenses to use MOX fuel they may not always do so.

\section{Uranium Enrichment Service Requirements}

The current worldwide enrichment capacity is 46.7 million separative work units (SWU). (See Appendix F for a detailed listing of facilities and their capacities.) Most of this capacity is located in the United States ( 41 percent), followed by the Russian Federation (24 percent) and France (23 percent). Effective July 1, 1993, the commercial enrichment business in the United States was transferred from the U.S. Department of Energy to the United States Enrichment Corporation (USEC), which is a government corporation. It is estimated that through 1997 the USEC will have about 74 percent of the enrichment market in the United
States. ${ }^{47}$ Most U.S. utilities have not yet selected the enrichment supplier to meet their enrichment services requirements from 1998 through 2010.

Total worldwide enrichment service requirements from 1994 through 2010 are projected at 527 to 569 million SWU (Table 14). Annual enrichment service requirements from 1994 through 2010 are projected to range from 27 to 40 million SWU (Table 15). It is important to note that the current enrichment capacity of 46.7 million SWU is more than enough to meet enrichment requirements worldwide through 2010. At a regional level, Western Europe accounts for 34 percent of total projected cumulative SWU requirements in the Low case through 2010, followed by the United States with 32 percent and the Far East with 18 percent (Figure 3).

The use of MOX fuel also replaces some enriched uranium with plutonium, resulting in lower enrichment requirements. If the reactors use MOX fuel according to the schedule assumed for this report, enrichment requirements in Western Europe and the Far East will be 8.5 percent less (Table 16).

\footnotetext{
${ }^{47}$ Nuclear Assurance Corporation, FOCUS: Quarterly Report on the Nuclear Fuel Cycle, Issue 27 (December 1993 ), p. 13.
} 
Table 14. Projected Cumulative Enrichment Service Requirements for World Nuclear Power Plants, 1994-2010

(Million Separative Work Units)

\begin{tabular}{|c|c|c|c|c|c|c|c|c|c|c|c|c|c|c|}
\hline \multirow[b]{2}{*}{ Year } & \multicolumn{2}{|c|}{ United States } & \multicolumn{2}{|c|}{ Canada } & \multicolumn{2}{|c|}{ Eastern Europe } & \multicolumn{2}{|c|}{ Western Europe } & \multicolumn{2}{|c|}{ Far East } & \multicolumn{2}{|c|}{ Other } & \multicolumn{2}{|c|}{ Total } \\
\hline & Low & High & Low & High & Low & High & Low & High & Low & High & Low & High & Low & High \\
\hline $1994 \ldots \ldots$ & 10.7 & 10.7 & 0.0 & 0.0 & 4.9 & 5.3 & 10.2 & 10.6 & 5.2 & 5.2 & 0.4 & 0.2 & 31.5 & 32.0 \\
\hline $1995 \ldots$ & 19.6 & 19.6 & 0.0 & 0.0 & 9.7 & 10.3 & 21.2 & 21.4 & 10.1 & 10.4 & 0.6 & 0.4 & 61.2 & 62.0 \\
\hline $1996 \ldots$ & 29.6 & 29.6 & 0.0 & 0.0 & 15.1 & 15.8 & 31.6 & 32.3 & 14.5 & 15.0 & 0.9 & 0.8 & 91.7 & 93.3 \\
\hline 1997 & 40.0 & 40.3 & 0.0 & 0.0 & 19.9 & 20.9 & 41.9 & 42.9 & 18.9 & 20.3 & 1.4 & 1.2 & 122.2 & 125.4 \\
\hline $2998 \ldots \ldots$ & 49.0 & 49.1 & 0.0 & 0.0 & 24.2 & 25.5 & 52.6 & 53.9 & 23.4 & 24.8 & 1.8 & 1.7 & 151.1 & 154.9 \\
\hline $1999 \ldots$ & 59.7 & 59.9 & 0.0 & 0.0 & 29.6 & 31.8 & 63.0 & 64.4 & 29.1 & 30.5 & 2.1 & 2.0 & 183.5 & 188.4 \\
\hline $2000 \ldots$ & 70.0 & 70.3 & 0.0 & 0.0 & 34.6 & 37.6 & 73.4 & 75.5 & 33.9 & 36.3 & 2.5 & 2.4 & 214.5 & 221.8 \\
\hline $2001 \ldots$ & 79.7 & 80.1 & 0.0 & 0.0 & 39.9 & 43.6 & 84.7 & 87.1 & 39.3 & 41.3 & 3.0 & 2.8 & 246.7 & 254.7 \\
\hline 2002 & 89.3 & 89.5 & 0.0 & 0.0 & 45.2 & 49.3 & 95.1 & 97.9 & 45.1 & 47.0 & 3.4 & 3.2 & 278.2 & 286.7 \\
\hline 2003 & 100.0 & 100.3 & 0.0 & 0.0 & 50.4 & 55.1 & 106.0 & 108.7 & 50.3 & 52.5 & 3.6 & 3.5 & 310.5 & 319.9 \\
\hline $2004 \ldots$ & 109.6 & 110.1 & 0.0 & 0.0 & 55.4 & 65.5 & 117.1 & 120.1 & 55.6 & 59.0 & 4.1 & 4.0 & 342.0 & 358.6 \\
\hline $2005 \ldots$ & 119.7 & 119.7 & 0.0 & 0.0 & 60.2 & 71.3 & 126.9 & 130.4 & 62.2 & 65.9 & 4.6 & 4.5 & 373.7 & 391.8 \\
\hline $2006 \ldots$ & 129.7 & 130.3 & 0.0 & 0.0 & 65.1 & 77.4 & 137.8 & 142.0 & 66.7 & 70.6 & 5.0 & 4.9 & 404.4 & 425.1 \\
\hline $2007 \ldots$ & 140.8 & 141.1 & 0.0 & 0.0 & 70.2 & 87.1 & 148.1 & 152.8 & 73.9 & 78.3 & 5.4 & 5.3 & 438.4 & 464.7 \\
\hline 2008 & 148.6 & 149.5 & 0.0 & 0.0 & 74.6 & 93.1 & 159.1 & 164.6 & 79.6 & 85.9 & 5.8 & 5.8 & 467.6 & 498.9 \\
\hline $2009 \ldots$ & 159.0 & 160.2 & 0.0 & 0.0 & 79.1 & 99.4 & 168.3 & 175.9 & 86.8 & 93.8 & 6.3 & 7.0 & 499.3 & 536.3 \\
\hline $2010 \ldots$ & 166.8 & 168.8 & 0.0 & 0.0 & 83.5 & 105.0 & 176.6 & 185.4 & 93.3 & 101.7 & 6.8 & 7.6 & 526.7 & 568.5 \\
\hline
\end{tabular}

Note: Totals may not equal sum of components due to independent rounding.

Source: Energy Information Administration, Office of Coal, Nuclear, Electric and Alternate Fuels, International Nuclear Model, File INM94.WK3.

Table 15. Projected Annual Enrichment Service Requirements for World Nuclear Power Plants, 1994-2010 (Million Separative Work Units)

\begin{tabular}{|c|c|c|c|c|c|c|c|c|c|c|c|c|c|c|}
\hline Year & \multicolumn{2}{|c|}{ United States } & \multicolumn{2}{|c|}{ Canada } & \multicolumn{2}{|c|}{ Eastern Europe } & \multicolumn{2}{|c|}{ Western Europe } & \multicolumn{2}{|c|}{ Far East } & \multicolumn{2}{|c|}{ Other } & \multicolumn{2}{|c|}{ Total } \\
\hline $1995 \ldots$ & 8.9 & 8.9 & 0.0 & 0.0 & 4.8 & 5.0 & 11.0 & 10.8 & 4.9 & 5.2 & 0.2 & 0.2 & 29.7 & 30.0 \\
\hline $1996 \ldots$ & 10.0 & 10.0 & 0.0 & 0.0 & 5.4 & 5.6 & 10.4 & 10.9 & 4.3 & 4.6 & 0.3 & 0.4 & 30.5 & 31.3 \\
\hline $1997 \ldots$ & 10.4 & 10.7 & 0.0 & 0.0 & 4.8 & 5.0 & 10.3 & 10.6 & 4.5 & 5.3 & 0.5 & 0.4 & 30.5 & 32.1 \\
\hline $2000 \ldots$ & 10.3 & 10.4 & 0.0 & 0.0 & 5.0 & 5.8 & 10.4 & 11.1 & 4.8 & 5.8 & 0.4 & 0.4 & 31.0 & 33.4 \\
\hline $2001 \ldots$ & 9.7 & 9.8 & 0.0 & 0.0 & 5.3 & 6.0 & 11.3 & 11.6 & 5.5 & 5.0 & 0.5 & 0.4 & 32.2 & 32.9 \\
\hline $2002 \ldots$ & 9.6 & 9.4 & 0.0 & 0.0 & 5.4 & 5.7 & 10.4 & 10.8 & 5.8 & 5.7 & 0.4 & 0.4 & 31.5 & 32.0 \\
\hline $2003 \ldots$ & 10.8 & 10.8 & 0.0 & 0.0 & 5.2 & 5.9 & 10.9 & 10.8 & 5.3 & 5.5 & 0.2 & 0.3 & 32.3 & 33.2 \\
\hline 2004 & 9.6 & 9.8 & 0.0 & 0.0 & 5.0 & 10.4 & 11.1 & 11.4 & 5.3 & 6.5 & 0.6 & 0.6 & 31.5 & 38.7 \\
\hline 2008 & 7.8 & 8.4 & 0.0 & 0.0 & 4.4 & 5.9 & 11.0 & 11.8 & 5.6 & 7.6 & 0.4 & 0.5 & 29.2 & 34.2 \\
\hline 2009 & 10.4 & 10.7 & 0.0 & 0.0 & 4.5 & 6.4 & 9.2 & 11.3 & 7.2 & 7.9 & 0.5 & 1.1 & 31.7 & 37.4 \\
\hline $2010 \ldots$ & 7.8 & 8.5 & 0.0 & 0.0 & 4.4 & 5.6 & 8.3 & 9.5 & 6.6 & 7.9 & 0.4 & 0.6 & 27.4 & 32.2 \\
\hline
\end{tabular}

Note: Totals may not equal sum of components due to independent rounding.

Source: Energy Information Administration, Office of Coal, Nuclear, Electric and Alternate Fuels, International Nuclear Model, File INM94.WK3. 
Figure 3. Total Enrichment Requirements by Region, 1994-2010, Low Case Projections (Million Separative Work Units)

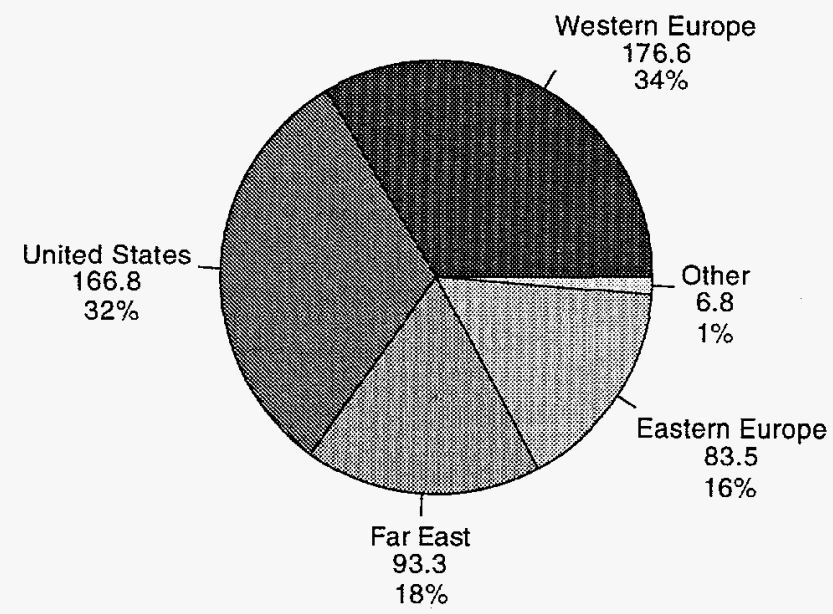

Source: Energy Information Administration, Office of Coal, Nuclear, Electric and Alternate Fuels, International Nuclear Model, File INM94.WK3.

\section{Uranium Market Developments}

\section{Introduction}

The world uranium market was again oversupplied in 1993, continuing a trend that started more than a decade ago. This situation is likely to continue over the next several years, chiefly due to the persistent inventory liquidations in the Western civilian markets and the availability of large amounts of civilian and military uranium from Russia and the other successor states of the Former Soviet Union (FSU). Reflecting the excess supplies in the market, the average unrestricted Nuexco spot-market price declined to $\$ 7.12$ per pound $\mathrm{U}_{3} \mathrm{O}_{8}$ in 1993 , compared to $\$ 7.95$ per pound in 1992 . $^{48}$ (In the United States, a two-tier market developed as a result of the suspension agreements that restrict imports from the Former Soviet Union. Therefore, the spot price in the restricted U.S. market was $\$ 2$ to $\$ 3$ higher per pound than in the unrestricted market.)

The nuclear industry of the Former Soviet Union and the Eastern European countries linked thereto was a

Table 16. Projected Annual Enrichment Requirements for Western Europe and the Far East With and Without MOX Fuel, Low Case, 1994-2010 (Million Separative Work Units )

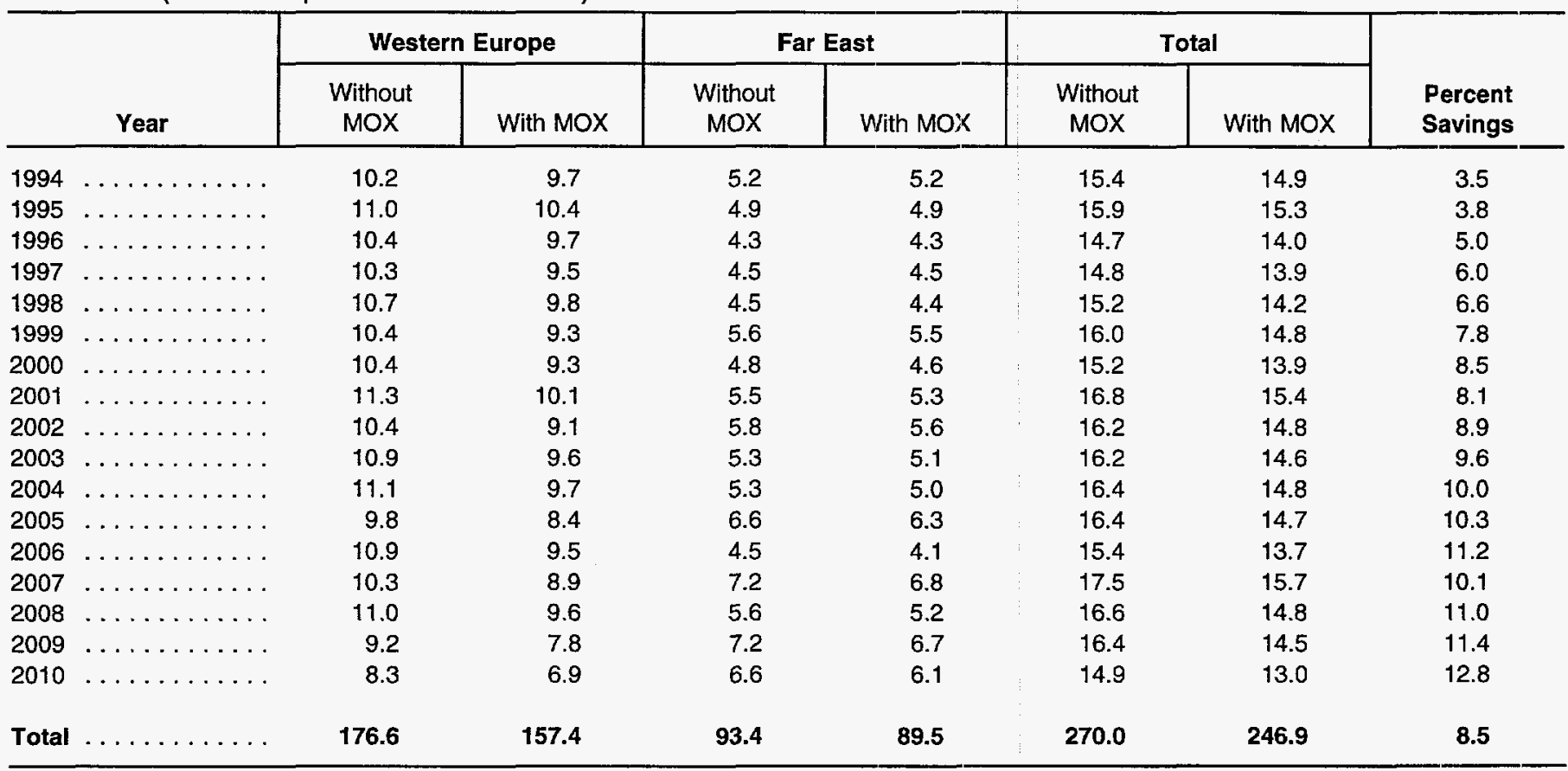

Note: Totals may not equal sum of components due to independent rounding.

Source: Energy Information Administration, Office of Coal, Nuclear, Electric and Alternate Fuels, International Nuclear Model, File INM94.WK3.

${ }^{48}$ Nuexco, Nuexco Review (Denver, CO, June 1994), p. 34. These prices are in norninal dollars. 
closed system until the breakup of the Soviet Union in 1991. A centralized, planned economy existed in that country for more than 70 years, and a centralized, integrated system governed the nuclear fuel supply for both military and civilian needs. The Soviet civilian nuclear power program was started by the same institutions responsible for nuclear weapons production. Uranium was routinely transferred between the two fuel cycles, with many facilities involved in both military and civilian activities.

Uranium exports from the Former Soviet Union to the West ${ }^{49}$ began in the late 1980 's, became increasingly important in the early 1990's, and contributed to further deterioration in the western markets. Now that the considerable civilian and military inventories of the FSU are being actively promoted in the western commercial nuclear fuel markets, uranium oversupply is likely to persist throughout the decade. Industry sources, such as Energy Resources International (ERI) and the Uranium Exchange Company (Ux), have estimated potential civilian and military inventories at over 1 billion pounds $\mathrm{U}_{3} \mathrm{O}_{8}$ equivalent: ${ }^{50}$ The ERI number is only for the FSU, while the Ux number also includes sales from the U.S. stockpile of Highly Enriched Uranium (HEU). These quantities are over and above those in the western civilian uranium stockpile, estimated at about 350 million pounds $\mathrm{U}_{3} \mathrm{O}_{8}$ equivalent. By comparison, annual worldwide uranium requirements to 2010 are estimated to be about 128 to 178 million pounds $\mathrm{U}_{3} \mathrm{O}_{8}$ equivalent (Table 12).

Various factors led to declining uranium prices in the West beginning in the early 1980's. Until the late 1980's, excess producer and utility inventories were sold in the marketplace and competed with new uranium production. These inventory liquidations were the main causes of uranium price declines. The excess inventories, in turn, were mostly due to reactor startup delays, cancellations of reactor construction programs, and the relative inflexibility of the U.S. Government's uranium enrichment program. Since about 1989, exports of uranium from the Former Soviet Union and, to a smaller extent from China, increasingly contributed to the decline in uranium prices. To control the flow of uranium from the Eastern Bloc, both the United States and the European Union took steps, starting in 1991, to restrict imports of uranium from these sources. As discussed in Appendix G, the United States signed suspension agreements with the uranium-producing successor states of the Soviet Union to link imports from these sources to a price schedule. However, because prices did not reach the expected levels, the Russian agreement was renegotiated and amended, signaling an eventual and inevitable increase in the quantity of Russian and other FSU material that will be sold in the United States. The European Supply Agency, the European Union's coordination agency for nuclear activities, applied an informal quota system to limit imports from the Former Soviet Union to about 20 percent of its annual uranium requirements, thus regulating the flow of Russian and other FSU material.

Despite these efforts to control the eastern uranium flow to the western markets, such supplies are the main causes of the more recent price erosions. The end of the Cold War and the easing of military tensions led to agreements between the United States and Russia to limit the number of strategic nuclear weapons, thereby potentially making available large quantities of uranium from the dismantled warheads of both nations as well as from the military stockpiles of uranium that supported the respective weapons programs. The agreement signed between the United States and Russia for the United States to purchase 500 metric tons of Russian HEU from dismantled weapons over a 20-year period represents the first major contribution of military material to the commercial markets. The details of the agreement are discussed in Appendix G. The European Supply Agency is not currently restricting most Russian HEU procurement activities in Europe.

As a result of these continuing developments in the marketplace, previous distinctions between military and civilian uses of uranium as well as between the supplies from the West and the East may no longer be applicable. Also, while the future uranium requirements are known with reasonable certainty, many options now exist for providing uranium to the civilian reactor market. Thus, there will be no uranium shortage for a number of years as uranium continues to be available from sources other than new production, the traditional source of supply.

\section{Domestic Uranium Market}

U.S. utilities purchased 15.5 million pounds $\mathrm{U}_{3} \mathrm{O}_{8}$ in 1993 from domestic suppliers (Table 17); 74 percent of

\footnotetext{
${ }^{49}$ The West refers to the area of the world outside of the current and former centrally planned economies; the East refers to the current and former centrally planned economies.

${ }^{50}$ Energy Resources International, Inc., 1994 Nuclear Fuel Cycle Supply and Price Report (Washington, DC, May 1994), p. 4-14; Uranium Exchange Company, The Uranium Market Outlook (Danbury, CT, January 1994 Quarterly Update), p. 1-3.
} 
Table 17. U.S. Uranium Market Data, 1992-1993

\begin{tabular}{|c|c|c|}
\hline & 1992 & 1993 \\
\hline & \multicolumn{2}{|c|}{ (Million Pounds $\mathrm{U}_{3} \mathrm{O}_{8}$ ) } \\
\hline \multirow{3}{*}{$\begin{array}{l}\text { Uranium used by utilities in feed assemblies } \\
\text { Deliveries by domestic utilities to U.S. and } \\
\text { foreign enrichment plants } \ldots \ldots \ldots \ldots \ldots\end{array}$} & 43.0 & 45.1 \\
\hline & & \\
\hline & 32.0 & 35.1 \\
\hline Concentrate production $\ldots \ldots \ldots \ldots \ldots \ldots \ldots$ & 5.6 & 3.1 \\
\hline Deliveries to U.S. utilities by domestic suppliers . . . . . . . . & 23.4 & 15.5 \\
\hline Utility imports (direct purchases) & 11.8 & 15.7 \\
\hline Supplier imports (direct purchases) & 11.5 & 5.3 \\
\hline 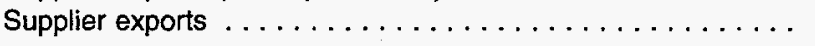 & 2.8 & 3.0 \\
\hline Utility inventory, natural uranium $\ldots \ldots \ldots \ldots \ldots \ldots$ & 66.5 & 57.6 \\
\hline Utility inventory, enriched uranium $\ldots \ldots \ldots \ldots \ldots \ldots$ & 25.5 & 23.1 \\
\hline Supplier inventory, natural uranium $\ldots \ldots \ldots \ldots \ldots \ldots$ & 19.1 & 18.7 \\
\hline Supplier inventory, enriched uranium & 6.1 & 5.0 \\
\hline \multirow[t]{2}{*}{ Total Inventories } & 117.3 & 104.4 \\
\hline & \multicolumn{2}{|c|}{ (Dollars per Pound $\mathrm{U}_{3} \mathrm{O}_{8}$ Equivalent) } \\
\hline \multicolumn{2}{|l|}{ Quantity-weighted average price of deliveries } & 13.14 \\
\hline $\begin{array}{l}\text { Quantity-weighted average price of deliveries to U.S. } \\
\text { utilities and suppliers under foreign purchase contracts }\end{array}$ & 11.34 & 10.53 \\
\hline Average spot-market price (unrestricted market) . & 7.95 & 7.12 \\
\hline Average spot-market price (restricted U.S. market) . . & $\left({ }^{a}\right)$ & 9.98 \\
\hline \multicolumn{3}{|c|}{$\begin{array}{l}\text { aNo average price for the year is available. } \\
\text { Note: Totals may not equal sum of components due to independent rounding. } \\
\text { Sources: 1992-Energy Information Administration, Uranium Industry Annual 1992, DOE/EIA-0478(92) } \\
\text { (Washington, DC, October 1993), pp. 16, 56, 60-61, 63. 1993-Energy Information Administration, Uranium } \\
\text { Industry Annual 1993, DOE/EIA-0478(93) (Washington, DC, September 1994), pp. XXviii, 33, 36, 42, 44-45. 1992- } \\
\text { 1993-Spot-Market Prices - Nuexco, Nuexco Review (Denver, CO, June 1994), p. 34. 1992- } \\
\text { 1993-Inventories-Energy Information Administration, Form EIA-858, "Uranium Industry Annual Survey" (1993). }\end{array}$} \\
\hline
\end{tabular}

these purchases were of foreign origin. ${ }^{51}$ At the end of 1993, utility contract commitments with domestic suppliers totaled 55.1 million pounds $\mathrm{U}_{3} \mathrm{O}_{8}$ for 1994 through $2002 .^{52}$ These commitments include options, and some of this material may not be delivered. Both domestic utilities and suppliers have contracted to import uranium, the latter to fill a portion of their domestic delivery commitments. The imports reported represent only primary purchases of uranium. In 1992, U.S. utilities purchased 23.4 million pounds $\mathrm{U}_{3} \mathrm{O}_{8}$ from domestic suppliers, with 64 percent of the purchases being of foreign origin. At the end of 1992 their contract commitments with domestic suppliers were 59.6 million pounds for: 1994 through $2002 .^{53}$

The 1993 direct imports totaled 21.0 million pounds $\mathrm{U}_{3} \mathrm{O}_{3}$ equivalent, 15.7 million pounds by utilities and 5.3 million pounds by suppliers. These imports came chiefly from Canada (52 percent), China (15 percent), Russia (9 percent), and Australia (about 7 percent), with the remairing quantity from various other countries, including Gabon, Kazakhstan, and Namibia. Import commitments of utilities and suppliers from 1994 through 2005 total 111.3 million pounds. ${ }^{54}$ Although

\footnotetext{
${ }^{51}$ Energy Information Administration, Uranium Industry Annual 1993, DOE/EIA-0478(93) (Washington, DC, September 1994), p. 30.

${ }^{52}$ Energy Information Administration, Form EIA-858, "Uranium Industry Annual Survey" (1993).

${ }^{53}$ Energy Information Administration, Form EIA-858, "Uranium Industry Annual Survey" (1992).

${ }^{54}$ Energy Information Administration, Form EIA-858, "Uranium Industry Annual Survey" (1993).
} 
Australia and Canada have large, high-grade, low-cost uranium resources, suppliers in those countries may not fill all their export commitments from their own resources. With the low spot-market price in recent years, some foreign suppliers also purchased uranium in the spot market from other countries to fill a portion of those commitments.

In 1992, direct imports by U.S. utilities and suppliers totaled 23.3 million pounds. Their contract commitments at the end of 1992 were 80.4 million pounds for 1994 through $2005 .^{55}$

U.S. suppliers exported 3.0 million pounds $\mathrm{U}_{3} \mathrm{O}_{8}$ equivalent to foreign buyers in 1993. Delivery commitments for 1994 through 2002 are 19.4 million pounds, ${ }^{56}$ more than double the 9.1 million pounds reported in the EIA 1992 Uranium Industry Annual Survey (Form EIA-858).

U.S. utilities shipped 27.3 million pounds $\mathrm{U}_{3} \mathrm{O}_{8}$ equivalent of foreign-origin uranium to enrichment suppliers in $1993 .{ }^{57}$ These shipments represented about threequarters (78 percent) of the total feed deliveries made by U.S. utilities to domestic and foreign enrichment suppliers. Total feed deliveries from all sources rose 3.1 million pounds from 1992 deliveries, with foreignorigin uranium shipments increasing by 5.4 million pounds. ${ }^{58,59,60}$ DOE enrichment plants received 32.4 million pounds $\mathrm{U}_{3} \mathrm{O}_{8}$ equivalent, and foreign enrichment plants received 2.7 million pounds. The foreign uranium shipped to the DOE came mostly from Canada, Russia, and China. U.S. utilities delivered 7.7 million pounds $\mathrm{U}_{3} \mathrm{O}_{8}$ equivalent of domestic-origin uranium to the DOE enrichment plants and 0.1 million pounds to foreign enrichment plants.

It should be noted, however, that in 1993 domestic utilities loaded 45.1 million pounds $\mathrm{U}_{3} \mathrm{O}_{8}$ equivalent into U.S. reactors in contrast to the 35.1 million pounds delivered to U.S. and foreign enrichment plants. The comparable 1992 data were 43.0 million pounds loaded into U.S. reactors versus 32.0 million pounds delivered to U.S. and foreign enrichers (Table 17).

\section{Domestic Inventories}

Over the past 10 years U.S. utilities have adopted inventory management policies that have resulted in lower year-end inventories of both natural and enriched uranium as compared to earlier periods. Such policies have become attractive with the availability of various forms of uranium through secondary transactions. More recently, the availability of uranium from the East has also allowed the utilities to reduce their inventory holdings to protect against a disruption of nuclear fuel supplies and to meet changes in the scheduling of various stages of the fuel cycle.

Inventories of both natural and enriched uranium owned by utilities at the end of 1993 totaled $80.7 \mathrm{mil}-$ lion pounds $\mathrm{U}_{3} \mathrm{O}_{8}$ equivalent, a drop of 11.3 million pounds from the 1992 end-of-year inventory. As of December 31, 1993, domestic uranium suppliers (producers and agents) held 23.7 million pounds $\mathrm{U}_{3} \mathrm{O}_{8}$ equivalent in inventory, 1.5 million pounds less than the previous year. Overall, inventories held by utilities and suppliers totaled 104.4 million pounds $\mathrm{U}_{3} \mathrm{O}_{8}$ equivalent at the end of 1993 in contrast to 117.3 million pounds that they held at year end 1992. Utilities had 92.1 million pounds in natural and enriched uranium inventories at the end of 1992, while suppliers had 25.2 million pounds in their inventories. ${ }^{61}$

\section{U.S. Uranium Industry Projections}

Projections of spot-market prices, net imports, domestic production, and inventories were developed for 1994 through 2005. ${ }^{62}$ As discussed in more detail in Appen$\operatorname{dix} B$, the derivation of these projections is based on certain assumptions, some of which relate to demand for uranium, the existing supply sources (i.e., production centers), and production from future production centers as a function of future market requirements. The assumptions also reflect information on the quality of reserves and the associated economic costs of mining, milling, and marketing; the levels of

\footnotetext{
${ }^{55}$ Energy Information Administration, Form EIA-858, "Uranium Industry Annual Survey" (1992).

${ }^{56}$ Energy Information Administration, Uranium Industry Annual 1993, DOE/EIA-0478(93) (Washington, DC, September 1994 ), p. 33.

${ }^{57}$ Feed deliveries to enrichment plants include exchanges of natural uranium for enriched uranium, but they do not include direct purchases of enriched uranium or any drawdowns of enriched uranium inventories.

${ }^{58}$ Energy Information Administration, Uranium Industry Annual 1993, DOE/EIA-0478(93) (Washington, DC, September 1994 ), p. 42.

${ }^{59}$ Energy Information Administration, Uranium Industry Annual 1992, DOE/EIA-0478(92) (Washington, DC, October 1993 ), p. 60.

${ }^{60} \mathrm{The}$ foreign-origin feed deliveries to domestic enrichment plants in any given year do not necessarily reflect imports for that year, since some of the material may be supplied from inventory.

${ }^{61}$ Energy Information Administration, Form ElA-858, "Uranium Industry Annual Survey" (1993).

${ }^{62}$ The Uranium Market Model, DOE/OR-21400-H11, used to produce the projections in this report, the data inputs, and a manual of operating instructions are available from the National Technical Information Service (NTIS), Department of Commerce, 5825 Port Royal Road, Springfield, Virginia 22161 (703/487-4600). Microfiche copies of the documentation for this model are also available from NTIS.
} 
current domestic and foreign inventories; and potential future additions to or withdrawals from inventory.

\section{Spot-Market Price}

As noted earlier in this chapter, natural uranium spotmarket prices in the unrestricted market continued to fall in 1993, reaching $\$ 7.12$ per pound $\mathrm{U}_{3} \mathrm{O}_{8}$ (nominal dollars), the lowest level since the early 1970's. The market value of uranium in real terms has declined by over 90 percent since the late 1970's, resulting in a corresponding shrinkage in the magnitude of both domestic and foreign uranium mining and milling operations as a whole. Western civilian inventory drawdowns provided a significant share of reactor requirements and contributed to the depressed price outlook in recent years. Currently, the market for uranium is still characterized to some degree by continuing liquidations of Western and Russian inventories. The rate at which present inventory levels will be reduced and the levels at which inventories will stabilize in the future remain uncertain. A significant price recovery is unlikely until worldwide inventories are reduced to levels that permit a more balanced interaction of supply and demand to determine uranium prices.

Over the forecast period, spot-market prices are likely to rise modestly in the near term to reflect the continuing effect on the uranium market of the suspension agreements and the amendment to the agreement with Russia. Beyond the near term, as the effect of inventory drawdowns diminishes, new uranium production is likely to be undertaken to meet demand. The projected price increase is very gradual. The spot price in constant 1993 dollars is expected to be slightly higher than $\$ 13$ per pound $\mathrm{U}_{3} \mathrm{O}_{8}$ by 2005 (Table 18).

\section{Net Imports}

Uranium is imported through purchases in the spot market and through long-term contractual commitments made by utilities, producers, and intermediaries. Some contracts for current deliveries were signed several years ago, and the current low level of uranium prices was not foreseen. If contracts contain firm prices
Table 18. Projected U.S. Spot-Market Prices for Uranium Under Current Market Conditions, 1994-2005 (Constant 1993 Dollars per Pound $\mathrm{U}_{3} \mathrm{O}_{8}$ )

\begin{tabular}{|c|c|}
\hline Year & Price: \\
\hline $1994 \ldots \ldots$ & 9.17 \\
\hline $1995 \ldots$ & 9.64 \\
\hline $1996 \ldots \ldots$ & 10.27 \\
\hline $1997 \ldots \ldots \ldots \ldots \ldots \ldots \ldots$ & 10.71 \\
\hline $1998 \ldots \ldots \ldots \ldots \ldots \ldots \ldots$ & 11.19 \\
\hline $1999 \ldots \ldots \ldots \ldots \ldots \ldots \ldots$ & $11.5 \%$ \\
\hline$\ldots \ldots \ldots \ldots$ & 11.85 \\
\hline$\ldots \ldots \ldots \ldots$ & 12.15 \\
\hline $2002 \ldots \ldots$ & 12.39 \\
\hline $2003 \ldots \ldots \ldots \ldots \ldots \ldots \ldots \ldots$ & 12.69 \\
\hline $2004 \ldots \ldots \ldots \ldots \ldots \ldots$ & 12.91 \\
\hline$\ldots \ldots \ldots \ldots$ & 13.26 \\
\hline
\end{tabular}

Source: Energy Information Administration, Uranium Market Model run no. 1994"15S.DAT, September 14, 1994.

at levels higher than the spot price, producers nay benefit financially by purchasing foreign uranium on the spot market for delivery to their customers, rather than obtaining the material from their own mining operations. Also, when contracts tie sales prices to prevailing spot prices, which is the case with more recent contracts, producers find it more expedient to buy foreign uranium in the spot market to meet the delivery commitments. In both situations, U.S. and other Western production declines to levels below contract commitments, resulting in increased uranium imports.

Uranium imports by domestic utilities and domestic suppliers in 1993 totaled 21.0 million pounds $\mathrm{U}_{3} \mathrm{O}_{8}$ equivalent. (These data are based on purchase contracts. $)^{63}$ Exports of uranium totaled 3.0 million pounds, bringing net imports for 1993 to 18.0 million pounds. Net uranium imports in 1993 were about 12 percent lower than those in 1992, chiefly because of fewer imports by domestic suppliers. ${ }^{64}$

From 1994 through 2000, domestic production is projected to supply less than 11 percent of domestic requirements (Table 19). Such levels contrast sharply with net imports, which are projected to supply 76 to 83 percent of requirements for those years. Net imports

\footnotetext{
${ }^{63}$ Note that data on uranium imports collected by the Energy Information Administration include only primary purchase contracts for imports. Therefore, they do not include exchanges, loans, shipments of foreign-origin uranium to U.S. companies for processing to be delivered to foreign customers, or purchase transactions between domestic utilities and domestic suppliers in which foreign uranium may be delivered at the supplier's option.

${ }^{64}$ In 1992, imports totaled 23.3 million pounds $\mathrm{U}_{3} \mathrm{O}_{8}$ equivalent. Subtracting exports of 2.8 million pounds gives net uranitum imports of 20.5 million pounds. Source: Energy Information Administration, Uranium Industry Annual 1992, DOE/EIA-0478(92) (Washington, DC, October 1993), p. 54.
} 
Table 19. Projected U.S. Uranium Requirements, Net Imports, Commercial Inventories, and Production of Uranium, 1994-2005

(Million Pounds $\mathrm{U}_{3} \mathrm{O}_{8}$ Equivalent)

\begin{tabular}{|c|c|c|c|c|}
\hline Year & Requirements $^{a}$ & Net Imports ${ }^{b}$ & $\begin{array}{l}\text { Commercial } \\
\text { Inventories }\end{array}$ & Production \\
\hline $1994 \ldots \ldots \ldots \ldots \ldots \ldots \ldots \ldots$ & 45.2 & 34.3 & 100.6 & 3.4 \\
\hline - & 46.7 & 36.3 & 87.2 & 4.4 \\
\hline$\ldots \ldots \ldots \ldots$ & 45.5 & 36.2 & 82.2 & 4.4 \\
\hline $1998 \ldots \ldots \ldots \ldots \ldots \ldots \ldots \ldots$ & 45.6 & 36.7 & 77.9 & 4.6 \\
\hline $2001 \ldots \ldots \ldots \ldots \ldots \ldots \ldots \ldots$ & 46.8 & 38.1 & 69.9 & 6.4 \\
\hline $2002 \ldots \ldots \ldots \ldots \ldots \ldots \ldots \ldots \ldots$ & 46.8 & 37.4 & 67.9 & 7.3 \\
\hline $2003 \ldots \ldots \ldots \ldots \ldots \ldots \ldots$ & 44.2 & 35.2 & 66.2 & 7.4 \\
\hline $2004 \ldots \ldots \ldots \ldots \ldots \ldots \ldots$ & 47.1 & 38.1 & 64.9 & 7.7 \\
\hline $2005 \ldots \ldots \ldots \ldots \ldots \ldots \ldots$ & 42.4 & 34.0 & 63.9 & 7.4 \\
\hline
\end{tabular}

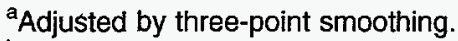

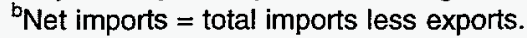

Source: Requirements-Energy Information Administration, International Nuclear Model, File INM94.WK3. Net Imports, Inventories and Production-Energy Information Administration, Uranium Market Model run no. 1994-15S.DAT, September 14, 1994.

will remain above 78 percent of the requirements for the remainder of the projection period, even though domestic production will supply greater percentages of requirements from 2001 through 2005 than in previous years.

\section{Inventories}

In anticipation of increased demand for uranium and the possibility of future shortages, U.S. uranium inventories began to build in the 1970's, with a peak at around 192 million pounds $\mathrm{U}_{3} \mathrm{O}_{8}$ equivalent in $1983 .{ }^{65}$ The relatively inflexible nature of enrichment contracts at that time contributed to the buildup of inventories. Other causes for the peak inventory levels in the early 1980 's were construction and licensing delays, cancellation of nuclear power plants, and the poor performance of existing units. A reversal of expectations regarding the future of nuclear power eventually led to a gradual liquidation of inventories after 1983. Uranium from civilian inventories is usually available at lower prices than from new production because most of the costs are sunk costs. Sellers of inventory are generally more concerned with current and future revenues than past costs.
Inventories of natural and enriched uranium held by utilities and suppliers consistently declined by an average of about 8 million pounds annually since 1983 and were 104.4 million pounds at the end of 1993 (Table 17). ${ }^{66}$ Predicting the extent to which utilities may dispose of their inventories in the future is complicated. Among the many factors an individual utility must consider are the years of requirements that can be satisfied by inventory, the price of the material in inventory, the availability of uranium loans, carrying costs, cash flow, actual or projected replacement costs for material purchased in the future, and, increasingly, the utility's perception of the magnitude and availability of uranium from foreign, especially Eastern, sources. These factors may vary widely from utility to utility, and the inventory strategies of different utilities also may vary.

It is estimated that the projected inventory levels for the mid-1990's are adequate to meet domestic reactor fuel requirements for about 2 years, but will be less than that for the remainder of the projection period. Projected inventory levels indicate a continuing decline each year between now and 2005 before stabilizing at a level deemed reasonably adequate to satisfy annual reactor requirements (Table 19).

\footnotetext{
${ }^{65}$ Energy Information Administration, Domestic Uranium Mining and Milling Industry 1991: Viability Assessment, DOE/EIA-0477(91) (Washington, DC, December 1992), Table D4, p. 73.

${ }^{66}$ The actual inventory levels may be lower than those reported here due to the possibility that some owners may not subtract inventory loans and/or leases from their holdings in a bookkeeping environment.
} 


\section{Domestic Production}

In the 1950's and 1960's, the domestic uranium mining and milling industry developed nonconventional mining methods, such as uranium recovery by in situ leaching (ISL) ${ }^{67}$ Significant amounts of uranium have been produced by these nonconventional methods since 1980. In 1993, together with recovery of uranium as a byproduct of phosphate mining, ISL accounted for almost all of the U.S. $\mathrm{U}_{3} \mathrm{O}_{8}$ production of 3.1 million pounds, or about 45 percent less than the 1992 production of 5.6 million pounds. ${ }^{68}$ Production in 1994 will continue to be provided principally from the ISL and phosphate byproduct recovery operations. Some conventional production may be resumed in 1995, probably from the milling of stockpiled ore.

Because the projections reflect a higher cost for domestic operations than for those of other countries, along with the availability of Eastern supplies, a large share of domestic demand is met by imports. ${ }^{69} \mathrm{~A}$ modest but continuing increase in uranium prices is projected from 1994 through 2005, which should induce domestic production to rise gradually to 5.4 million pounds in 2000 (Table 19). In subsequent years, as the price trajectory continues its upward trend, domestic uranium production is expected to reach 7.7 million pounds by 2004 but decline slightly to 7.4 million pounds in 2005. As inventories are liquidated, however, a large portion of aggregate domestic uranium demand will continue to be met by imports, even with modestly increasing levels of projected domestic production.

\section{Uranium Resources}

As discussed earlier in this chapter, over the past decade uranium imports have gradually become more important in supplying the uranium requirements of U.S. nuclear reactors. Projections indicate that imports will persist as a major component of the U.S. uranium supply in the future as well. For a better understanding of the.worldwide uranium supply, this section provides data and analysis on U.S. and foreign uranium resources.

\section{U.S. Uranium Resources}

U.S. uranium resources are categorized as Reserves, Estimated Additional Resources (EAR), and Speculative Resources (SR). EAR and SR are undiscovered geological resources of uranium minerals, the existence of which has been estimated with varying degrees of confidence. Reserves are mineral deposits for which size, configuration, and production costs have been determined; they correspond to the category of Reasonably Assured Resources (RAR) as used by the International Atomic Energy Agency and the Nuclear Energy Agency. EAR are estimates of additional uranium deposits expected to occur as extensions of known deposits in well-defined geologic trends. ${ }^{70}$

Low-cost U.S. reserves are defined as having forward costs of $\$ 30$ per pound $\mathrm{U}_{3} \mathrm{O}_{8}$ or less. As of December 31, 1993, they are estimated to be 292 million pounds $\mathrm{U}_{3} \mathrm{O}_{8}$. Medium-cost reserves have forward costs of $\$ 50$ per pound or less and are estimated to be 952 million pounds $\mathrm{U}_{3} \mathrm{O}_{8}{ }^{71}$ The known U.S. low- and medium-cost reserves of uranium as of December 31, 1993, do not include uranium recoverable as a byproduct from phosphate and copper mining. Low-cost EAR are estimated at 2.2 billion pounds $\mathrm{U}_{3} \mathrm{O}_{8}$, and the medium-cost resources contribute another 1.2 billion pounds. Additional resources can be made available at much higher costs of extraction. Also, potential resources may be found and developed into known resources with aggressive exploration programs like those of the 1970's.

\section{Foreign Uranium Resources}

In the 1970's, optimistic projections of nuclear power growth resulted in intensive uranium resource appraisal activity in much of the world. Prior to 1985, cumulative foreign exploration expenditures (excluding the Former: Soviet Union, Eastern Europe, and China) were around $\$ 3.1$ billion. Reported expenditures were about $\$ 98$ million in 1992 but were expected to decline to $\$ 75$ million in 1993; data for 1992 and 1993 include the expenditures of the Russian Federation but not the other FSU republics. ${ }^{72}$ The highest expenditures for

\footnotetext{
${ }^{67}$ In situ leaching is the recovery of valuable components of a mineral deposit by a process of leaching without physical extraction of the mineralized rock from the ground (also referred to as "solution mining").

${ }^{68}$ Minor quantities of uranium were produced from other chemical processing operations.

${ }^{69}$ For the sake of simplicity, the recent suspension agreements may be viewed as a way to establish the cost of producing uranium in six of the former Soviet republics.

${ }^{70} \mathrm{~A}$ more detailed discussion of uranium resources and reserves is provided in Chapter 1 of the Uranium Industry Annual 1993.

${ }^{71}$ Energy Information Administration, Uranium Industry Annual 1993, DOE/EIA-0478(93) (Washington, DC, September 1994 ), p. 12.

${ }^{72}$ OECD Nuclear Energy Agency and International Atomic Energy Agency, Urarium 1993: Resources, Production and Demand (Paris, France, 1994), p. 32. Data are in nominal dollars.
} 
exploration in recent years have been in Canada and France.

Foreign Reasonably Assured Resources (RAR) are concentrated in comparatively few countries-chiefly, Australia, Brazil, Canada, Namibia, Niger, and South Africa. France and India conducted aggressive exploration programs in the 1980's, but they have been concerned largely with supplying their domestic needs and not with exporting uranium. French companies or their subsidiaries continue their prospecting and/or mining activities in Australia, Canada, Spain, and the United States. Australia and Canada dominate the world uranium resource picture, the result of their apparently abundant resources as well as intensive efforts to develop their resources. The reliability and timeliness of the uranium resource estimates may differ from country to country, largely because of the varying levels of effort applied to resource estimation by individual governments.

As of December 31, 1992, foreign RAR of 3.7 billion pounds $\mathrm{U}_{3} \mathrm{O}_{8}$ were estimated to be available at a cost of $\$ 30$ per pound, and RAR of 4.8 billion pounds $\mathrm{U}_{3} \mathrm{O}_{8}$ were estimated at up to $\$ 50$ per pound. Five countries-Australia, Brazil, Canada, Niger, and South Africa-contain 85 percent of the reported $\$ 30$ per pound RAR; the RAR in these countries are greater than those in the United States. At the end of 1992, Australian RAR at $\$ 30$ per pound were 1.2 billion pounds $\mathrm{U}_{3} \mathrm{O}_{8}$, more than double the reported RAR of any other country except Canada. ${ }^{73}$

It should be noted that China, Eastern Europe, and the Former Soviet Union have known uranium resources and are reported to possess significant export potential. However, reliable data regarding the magnitude of their resources and the forward costs of their production are still not available. The availability of relevant data on these countries will permit a more accurate assessment of RAR in the future.

In Canada, production by 2000 is planned from four large uranium deposits being developed in the Athabasca Basin in northern Saskatchewan. Reserves for the
Cigar Lake deposit are estimated at 385 million pounds $\mathrm{U}_{3} \mathrm{O}_{8}$, while those at the McArthur River deposit total 260 million pounds. The McClean and Midwest deposits have 45 and 36 million pounds in reserves. ${ }^{74}$

A joint federal/provincial panel has reviewed the environmental, health, safety, and socioeconomic impacts of proposed uranium mine developments, and in early 1993 it recommended that Cameco be allowed to proceed with underground exploration at the McArthur River deposit. Later in the year, the panel approved Cluff Mining's Dominique-Janine extension, and the government concurred in this recommendation. The government accepted the Panel's recommendation against proceeding with Denison Mines' development of an underground mine at the Midwest property; however, it rejected the panel's recommended suspension of the McClean Lake project for at least 5 years, so that the proposed tailings management system could be fully reviewed. The government overturned that advice, noting that tailings had been successfully managed at Rabbit Lake in the past decade. Also during 1993, another environmental assessment panel recommended the approval of full production at Cameco's Eagle Point underground uranium mine. ${ }^{75}$

\section{Production Capabilities}

The available foreign uranium production capability at $\$ 30$ per pound $\mathrm{U}_{3} \mathrm{O}_{8}$ from existing and committed centers is presented in Table $20 .^{76}$ No data on production capability are included for China and the Former Soviet Union, because data are either unreliable or considered insufficient. Moreover, restrictions are currently in place on uranium exports to the United States from certain FSU republics, as explained in greater detail in Appendix G. Australia and Canada, which have about half of the foreign production capabilities (excluding China and the FSU), also account for many of the export commitments to the United States over the next decade. After all current commitments have been subtracted, the remaining low-cost foreign production capability is more than adequate to meet buyers' future needs in the United States.

\footnotetext{
${ }^{73}$ OECD Nuclear Energy Agency and International Atomic Energy Agency, Uranium 1993: Resources, Production and Demand (Paris, France, 1994), Tables 1-2, pp. 24-25.

${ }^{74}$ Nuexco, 1993 Annual Nuexco Review (Denver, CO, 1993), p. 88.

${ }^{75}$ Nuexco, 1993 Annual NUEXCO Review (Denver, CO, 1993), pp. 87-88.

${ }^{76}$ OECD Nuclear Energy Agency and International Atomic Energy Agency, Uranium 1993: Resources, Production and Demand (Paris, France, 1994), Table 12.
} 
Table 20. Foreign Production Capability at $\$ 30$ per Pound $\mathrm{U}_{3} \mathrm{O}_{8}$ (Thousand Pounds $\mathrm{U}_{3} \mathrm{O}_{8}$ )

\begin{tabular}{|c|c|c|c|}
\hline $\begin{array}{c}\text { Country or } \\
\text { Region }\end{array}$ & 1995 & 2000 & 2005 \\
\hline Canada ... & 21,578 & 30,678 & 16,639 \\
\hline Australia ......... & 10,919 & 15,339 & 15,339 \\
\hline Namibia & 9,099 & 9,099 & 9,099 \\
\hline Niger . . . . & 8,839 & 8,839 & 8,839 \\
\hline S. Africa $\ldots \ldots \ldots$ & 4,940 & 4,940 & 4,940 \\
\hline Gabon & 3,900 & 3,900 & 3,900 \\
\hline Europe ..... . & 9,619 & 4,940 & 4,680 \\
\hline S. America ....... & 1,495 & 1,495 & 1,417 \\
\hline Asia & 598 & 650 & 780 \\
\hline Total & 70,987 & 79,880 & 65,633 \\
\hline
\end{tabular}

Note: Capability is for existing and committed production centers.

Source: OECD Nuclear Energy Agency and International Atomic Energy Agency, Uranium 1993: Resources, Production and Demand (Paris, France, 1994), Table 12.

\section{Commercial Spent Fuel}

Management of spent fuel has always been one of the most important tasks in the nuclear fuel cycle, and it is still one of the most vital problems common to all countries with nuclear reactors. ${ }^{77}$ Reprocessing/recycling of the spent fuel or direct disposal are the two primary solutions to this problem. Most countries have chosen the reprocessing option. ${ }^{78}$ Reprocessing reduces the volume of radioactive waste by separating the uranium and plutonium from the irradiated fuel. The recovered uranium can be reused as fuel (referred to as a closed fuel cycle), and as discussed in a previous section, the plutonium can be used in mixed-oxide fuel for light-water reactors, which some countries are now pursuing. ${ }^{79}$ The United States and Canada are the only countries that rely entirely on direct disposal for managing their spent fuel. Many countries have deferred their decisions while different approaches are evaluated.

\section{Spent Fuel Projections}

From 1994 through 2010, total spent fuel clischarges worldwide are projected to be between 169 thousand and 176 thousand metric tons of uranium (MTU) (Table 21). In Western Europe, for the Low Case, an estimated 50 MTU of spent fuel will be discharged between 1994 and 2010, accounting for about 30 percent of worldwide spent fuel discharges (Figure 4). In the United States; 35 MTU will be discharged from 1994 through 2010, representing 20 percent of the total. Worldwide, annual spent fuel discharges are projected to range from 9 thousand to 11 thousand MTU from 1994 through 2.010 (Table 22).

Delays in selecting a spent fuel management program in some countries, the rejection of the reprocessing option in others, limited reprocessing capacity that cannot keep pace with spent fuel discharges, and delays in the availability of final spent fuel disposal in almost all countries have led to increasingly long periods of interim spent fuel storage. The problem of spent fuel management has, therefore, increased in importance for many countries. Spent fuel disposal issues in the United States present a concrete example. Through 1993, commercial nuclear reactors in the United States have permanently discharged 28.0 thousand MTU of spent fuel. ${ }^{80}$ The U.S. spent fuel inventory is projectecl to increase by 1.8 thousand to 2.3 thousand MTU per year through 2010, when it will reach about 62 thousand MTU. As the spent fuel inventory in the United States increases, it becomes urgent for the U.S. Department of Energy (DOE) to resolve the complex issues of collecting spent fuel from the nuclear utilities and completing the permanent disposal facility.

\section{Status of the U.S. Civilian Nuclear Waste Program}

The Nuclear Waste Policy Act of 1982 (NINPA) assigned the responsibility for disposal of commercial

\footnotetext{
${ }^{77} \mathrm{~F}$. Takats, "International Status and Trends for Spent Fuel Management," Journal of Nuclear Materials Management, Volume XXII, Number III (April 1994), p. 38.

${ }^{78}$ Reprocessing is the operation of recovering the uranium and plutonium isotopes from the spent fuel, while the rest (cladding, fission products, transuranics, contaminated chemicals, etc.) becomes high-level radioactive waste. The recovered uranium and plutorium represents at least 97 percent of the total volume of irradiated fuel.

${ }^{79}$ It should be noted that monitoring and control of the production of plutonium is an important issue because of its potential use in nuclear weapons. Also, because of the efforts in the United States and Russia to reduce the number of nuclear weapons, the disposition of the plutonium contained in those weapons is an important issue.

${ }^{80}$ Energy Information Administration, Form RW-859, "Utility Data Survey" (July 1994).
} 
Table 21. Projected Cumulative Discharges of Spent Fuel for World Nuclear Power Plants, 1994-2010 (Thousand Metric Tons of Uranium)

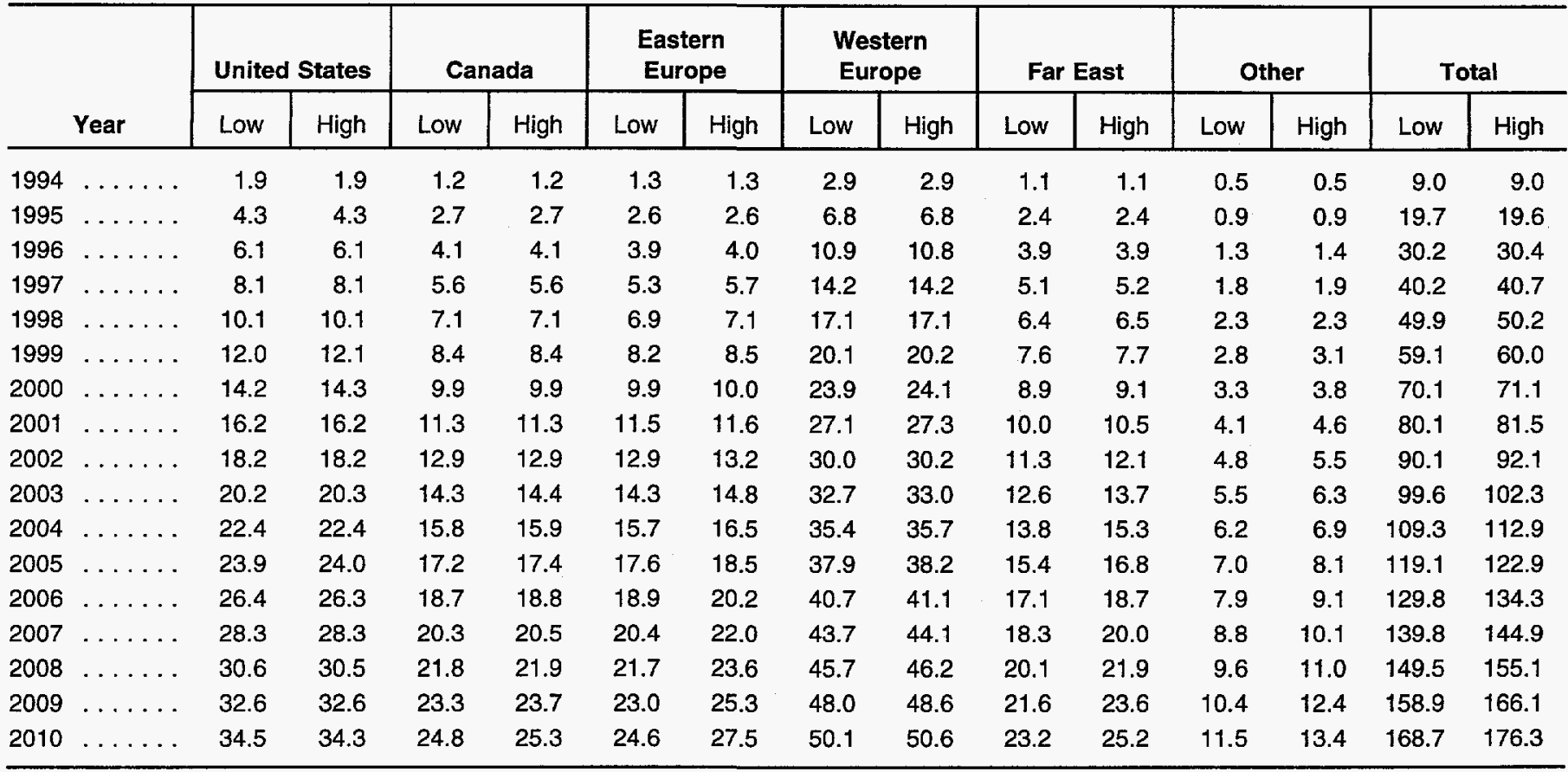

Note: Totals may not equal sum of components due to independent rounding. Spent fuel projections in the Low Case are sometimes larger than spent fuel projections in the High Case due to more reactors retiring in the Low Case and consequently discharging the entire reactor core.

Source: Energy Information Administration, Office of Coal, Nuclear, Electric and Alternate Fuels, International Nuclear Model, File INM94.WK3.

Table 22. Projected Annual Discharges of Spent Fuel for World Nuclear Power Plants, 1994-2010 (Thousand Metric Tons of Uranium)

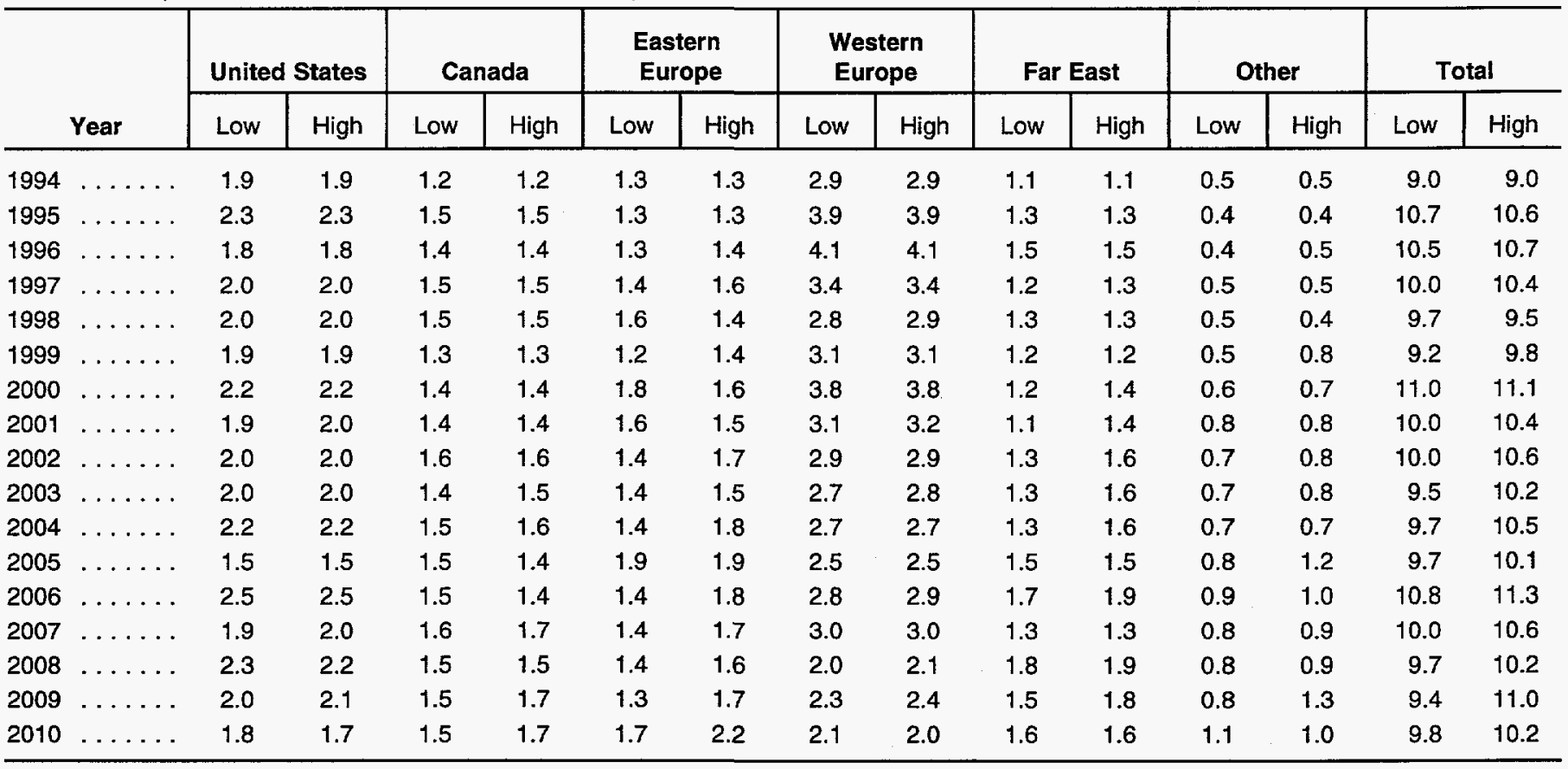

Note: Totals may not equal sum of components due to independent rounding. Spent fuel projections in the Low Case are sometimes larger than spent fuel projections in the High Case due to more reactors retiring in the Low Case and consequently discharging the entire reactor core.

Source: Energy Information Administration, Office of Coal, Nuclear, Electric and Alternate Fuels, International Nuclear Model, File INM94.WK3. 


\section{Figure 4. Total Spent Fuel Discharges by Region, 1994-2010, Low Case Projections \\ (Thousand Metric Tons of Uranium)}

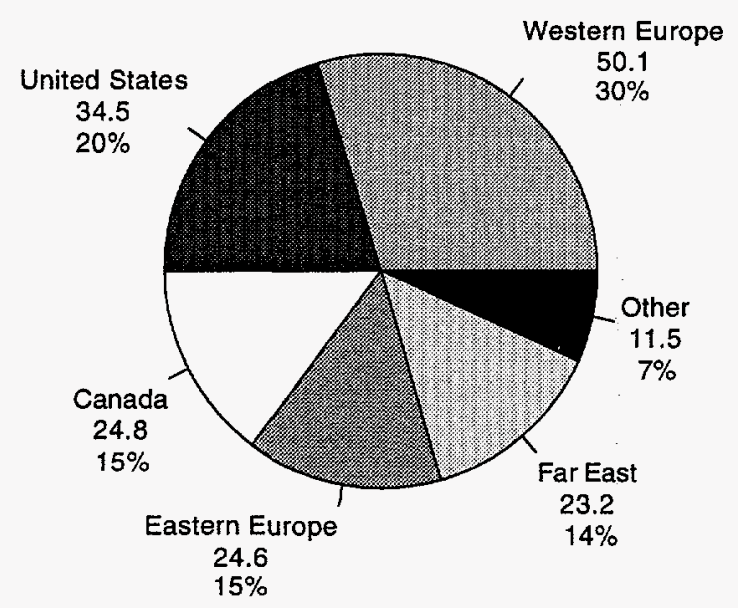

Source: Energy Information Administration, Office of Coal, Nuclear, Electric and Alternate Fuels, International Nuclear Model, File INM94.WK3.

spent fuel to the Federal Government. The Act also called for the selection and characterization of sites for a geologic repository and the creation of the Office of Civilian Radioactive Waste Management (OCWRM) within DOE to administer the program. ${ }^{81}$ The mission of the OCRWM is to manage the disposal of the Nation's commercial spent fuel and high-level radioactive waste (HLW) in a manner that protects the health and safety of the public and the workers, and the quality of the environment. The NWPA established 1998 as a target year for the government to begin accepting spent fuel from utilities. Since the law was enacted, the official estimate for the availability of a Mined Geologic Disposal System has slipped from 1998 to 2010. More delays in the schedule are possible because of complex processes for site characterization and licensing.

\section{Site Selection and Site Characterization}

Initially, nine potential repository sites were identified, but the Nuclear Waste Policy Amendments Act of 1987 reduced the number of sites to one, Yucca Mountain,
Nevada. After an extensive delay in getting the state of Nevada to issue work permits, site characterization of Yucca Mountain began. The major activity of site characterization is the development of an Exploratory Studies Facility (ESF), an underground laboratory that will be used to conduct tests, in situ, on the geologic, hydrologic, and geochemical properties of the site. In April 1993, excavation of a starter tunnel for the ESF began. The completion of the starter tunnel in September 1993 and the acquisition of a tunnel boring machine in April 1994 will enable the Yucca Mourtain project office to proceed with the development of an underground cavern for evaluating the suitability of the site. The network of underground tunnels and ramps could eventually total 13 miles.

\section{Monitored Retrievable Storage}

Monitored Retrievable Storage (MRS) is an aboveground temporary facility that could be used to store a limited quantity of spent fuel from commercial nuclear reactors until the permanent geologic repository is available. It was initially thought that a location for the MRS could be identified and construction completed in time to meet the original commitment of accepting spent fuel by $1998 .^{82}$ The DOE awarded a total of 12 Phase I grants to potential host sites for the MRS; these grants were used to evaluate the technical, sccial, economic, and political aspects of spent fuel storage and transportation. Phase II(a) grants, designed to continue the evaluation of the sites, were awarded to three applicants. During 1993, two of the three applicants, the Mescalaro Apache Tribe of New Mexico and the Skull Valley Band of Goshutes of Utah, expressed an interest in proceeding with Phase II(b) grants. The grants, with a value up to $\$ 2.8$ million, could be used to perform environmental, technological, and socioeconomic assessments. The MRS program, however, has received considerable opposition. The State of New Mexico is opposed to the MRS, and both houses of the State legislature have passed resolutions opposing spent fuel storage, despite the tribes' sovereignty. In late 1993, negotiations between the State and the Mescalero tribe were at a standstill. Senator Jeff Bingaman of New Mexico attached provisions to a 1994 appropriations bill that bars the DOE from awarding grant money to a State or Indian tribe considering an MRS. Progress with the Skull Valley Goshutes and the

\footnotetext{
${ }^{81}$ Information on the Civilian Radioactive Waste Program was obtained from the following sources: "Spent Fuel Management Seminar," sponsored by the Institute of Nuclear Materials Management (Washington, DC, January 26-28, 1994) and "Fifth International High-Level Radioactive Waste Management Conference," sponsored by the American Nuclear Society and the American Society of Civil Engineering (Las Vegas, Nevada, May 22-26, 1994).

${ }^{82}$ On June 20, 1994, 20 States and 14 utilities filed lawsuits asking the U.S. Department of Energy to begin accepting nuclear waste by January, 1998.
} 
State of Utah also has been slow. As a result of the slowdown in the MRS voluntary siting process, major emphasis in the program was placed on developing the multipurpose canister system.

\section{Multi-Purpose Canister System}

The multipurpose canister (MPC) is a sealed metallic container that will be used for storage, transportation, and disposal of spent fuel assemblies. MPC's are sealed to provide a dry, inert environment for the spent fuel and are overpacked (i.e., the canister is wrapped in a shield) uniquely for the various configurations used for on-site storage, transportation, and geologic disposal. A conceptual design report for the MPC was completed in September 1993.

The MPC system has the potential to reduce overall waste management costs. Although the costs of the MPC system are higher than other techniques, they are partially offset by reduced handling of the spent fuel, simpler MRS and repository facilities, and reduced transportation and disposal costs. Also, the use of the MPC for at-reactor dry spent fuel storage will allow reactors that are shut down permanently to decommission their spent fuel pools, with a substantial cost savings. The OCRWM is developing a strategy to perform the design, licensing, fabrication, and testing of two MPC design concepts as part of the overall strategy for implementing the MPC.

\section{At-Reactor Spent Fuel Storage Requirements}

The urgency of resolving the problems of spent fuel disposal in the United States becomes apparent when current spent fuel storage capacity is examined. At the end of 1992, three operating nuclear plants were using Independent Spent Fuel Storage Installations (ISFSI) to store spent fuel. ${ }^{83}$ Six other nuclear plants have applied to the Nuclear Regulatory Commission for an ISFSI license. Baltimore Gas and Electric's application was approved in November 1992. Also, some spent fuel has been shipped to away-from-reactor storage facilities. Most power plants do not have sufficient pool capacity to store the entire amount of fuel that will eventually be discharged from their reactors.

Assuming that the Low Case represents the volume of spent fuel discharged from U.S. reactors through 2010, the amount of spent fuel exceeding wet pool storage capacity is projected to be about 1.6 thousand MTU by 1998, increasing to 11.5 thousand MTU by 2010 (Figure 5 ). To meet these storage needs, some utilities may consider expanding their storage pools or developing ISFSIs in which the spent fuel would be stored above ground in dry casks. By 1998, over 20 reactor sites will need additional storage capacity over their current pool storage capacity, and by 2010 the number will increase to 70 reactor sites (Figure 6). Development of the MPC system, discussed previously, may help to alleviate the shortage of spent fuel storage capacity.

\section{Figure 5. Projections of U.S. Utility Spent Fuel Exceeding Wet Pool Storage Capacity Through 2010}

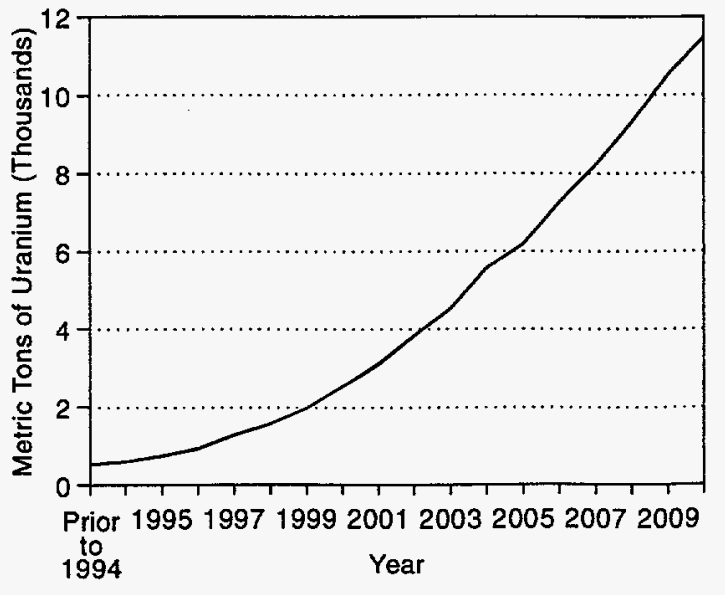

Note: The volume of spent fuel discharges used to estimate overflow is from the Low Case.

Source: Energy Information Administration, Form RW859, "Nuclear Fuel Data" (1993), and the International Nuclear Model, File INM94.WK3.

\footnotetext{
${ }^{83}$ Independent Spent Fuel Storage Installations are aboveground, dry storage facilities. They include metal storage casks, concrete modules, and concrete storage vaults. Energy Information Administration, Spent Nuclear Fuel Discharges from U.S. Reactors 1992, SR/CNEAF/94-01 (Washington, DC, May 1994), pp. 49-50.
} 
Figure 6. Projected Number of U.S. Reactor Sites Needing Additional Storage Capacity

Through 2010.

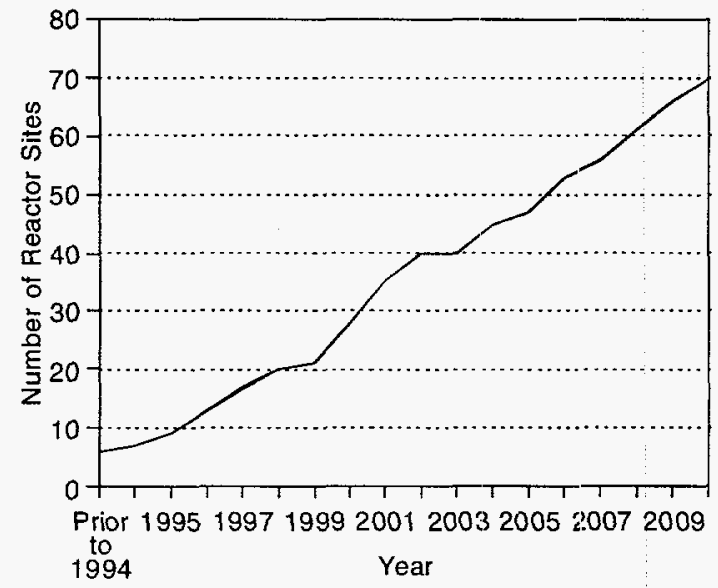

Note: The volume of spent fuel discharges used to estimate the number of reactor sites is from the Low Case.

Source: Department of Energy, Spent Fuel Storage Requirements 1993-2040, Draft, (Washington, DC, September 1994), pp. B74, B79. 


\section{Operating and Maintenance Costs for Nuclear Power Plants in the United States}

\section{Introduction}

Operating and maintenance (O\&M) costs (including the cost of fuel) for nuclear plants escalated rapidly in the 1970 's and early 1980's, surpassing those for coal-fired plants in 1987 (Figure 7). Although the average O\&M costs for U.S. nuclear power plants have been decreasing since 1987, they are still higher than the average costs for U.S. coal-fired power plants. ${ }^{84}$ The future of nuclear power in the United States will depend on the ability of the nuclear power industry to make nuclear plants economically competitive with other sources of electricity generation. The purpose of this chapter is to look at trends in the O\&M costs for the U.S. nuclear power plants, to discuss some of the factors contributing to the increase, and to discuss industry initiatives aimed at controlling costs. A statistical analysis of $O \& M$ costs for nuclear plants of different sizes and ages is also presented.

Chapter 5 of World Nuclear Capacity and Fuel Cycle Requirements 1993 contained information on U.S. capacity factors. The last section of this chapter presents an update to that work.

\section{Cost Reporting Conventions and Data Sources}

Costs reported in this chapter are presented in 1992 dollars. Except where noted, O\&M costs do not include the cost of fuel. For comparison among nuclear power plants, fuel costs add little to the discussion because the variance in fuel costs among reactors is small.

Two measures used for the analysis are O\&M costs per megawatt of capacity (MWe) and per megawatthour of electricity generation (MWh). Both measures provide useful information, and together, they present a com-

\author{
Figure 7. Comparison of Average Operating and \\ Maintenance Costs for U.S. Nuclear \\ and Coal-Fired Power Plants, 1981-1992
}

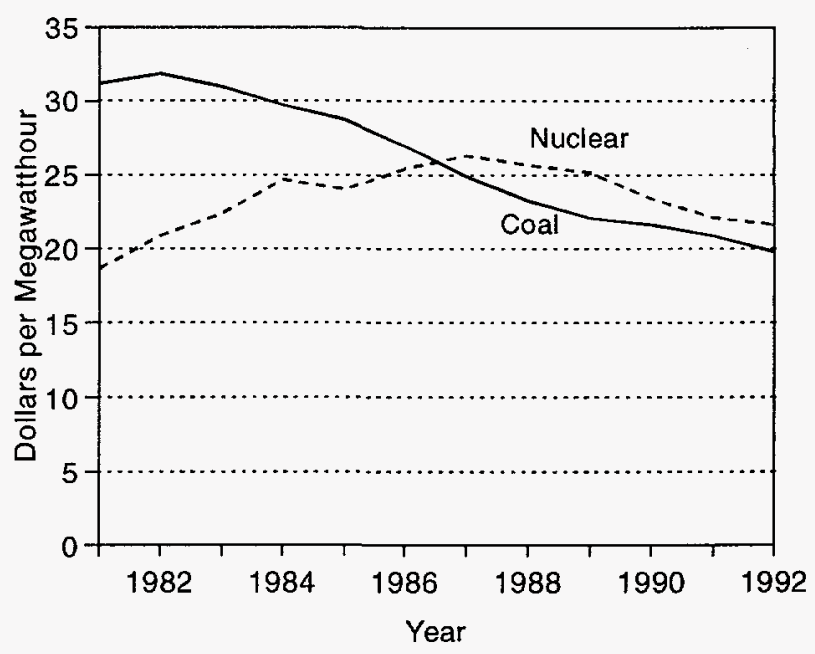

Notes: Costs are in 1992 dollars. Fuel costs are included. Source: Federal Energy Regulatory Commission, Form 1 (data obtained from the Utility Data Institute).

comprehensive picture of O\&M costs. O\&M costs per MWh indicate, in part, the cost of the electricity generated and are used in the ratemaking process. O\&M costs per MWe provide an indication of how well each utility is controlling overall costs at the plant level, independent of electricity output.

The data used in this analysis were obtained from the Federal Energy Regulatory Commission (FERC) Form 1, "Annual Report of Major Electric Utilities, Licensees and Others." The form is completed in conformity with the Uniform System of Accounts (18 CFR 101). Utilities have some discretion when completing this form because some costs such as manpower, overhead, and finance charges may be allocated at either the plant or the utility level. ${ }^{85}$ In addition, some utilities may elect

\footnotetext{
${ }^{84}$ Comparisons of coal and nuclear costs may vary from region to region depending on the proximity of the coal plant to the coal mines. Transportation is a major component of the cost of coal.

${ }^{85}$ It has been estimated that, on average, O\&M costs reported at the plant level understate actual costs by 20 to 30 percent, with the difference being reported at the utility level. See H.I. Bowers, L.C. Fuller, and M.L. Myers, Cost Estimating Relationships for Nuclear Power Plant Operation and Maintenance, ORNL/TM-10563 (Oak Ridge, TN: Oak Ridge National Laboratory, November 1987 ).
} 
to expense capital additions, while other utilities may capitalize them. Only costs reported at the plant level are considered here. Consequently, plant-by-plant cost comparisons should be viewed cautiously. On the other hand, trends in costs should not be greatly influenced by variations in utility accounting procedures because, within a utility, accounting procedures tend to be fairly stable over time.

The analysis is based on data for all commercial lightwater reactors (LWR's) operating in the United States between 1981 and 1992. Data on Fort St. Vrain, a hightemperature gas reactor (HTGR) that has been retired from service, are not included. The problem-plagued Fort St. Vrain plant had relatively high O\&M costs and extremely low capacity factors when it operated.

\section{Trends and Variations in Nuclear O\&M Costs}

Industry-wide average O\&M costs per MWh (expressed in 1992 dollars) were $\$ 10.43$ in 1981 and $\$ 15.37$ in 1992, 47-percent higher (Figure 8). O\&M costs per MWh peaked in 1987 at $\$ 16.91$ and declined modestly

\section{Figure 8. Average Operating and Maintenance Costs for U.S. Nuclear Power Plants, 1981-1992}

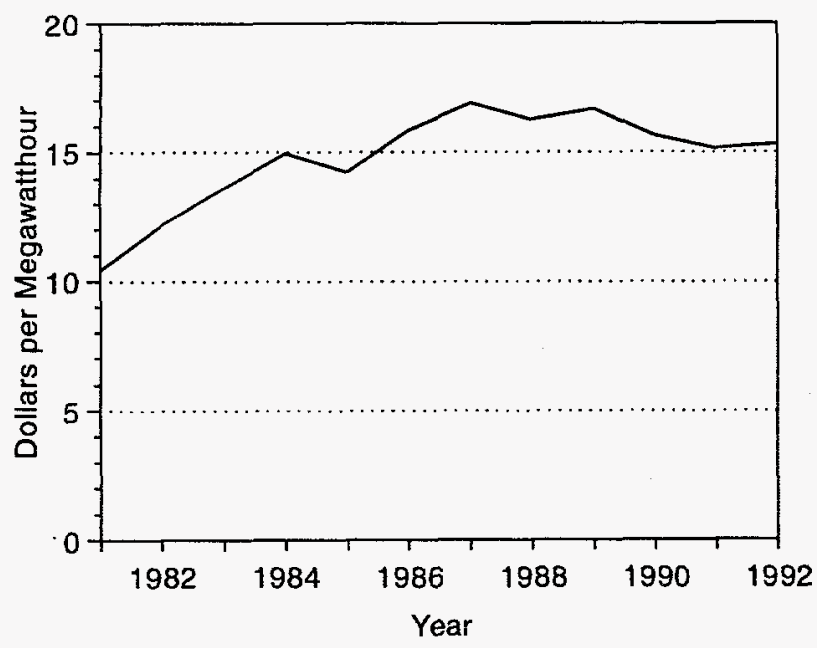

Notes: Costs are in 1992 dollars. Fuel costs are excluded. Source: Federal Energy Regulatory Commission, Form 1 (data obtained from the Utility Data Institute). from 1989 through 1992. The decline can be attributed, in part, to an improvement in capacity utilization of nuclear reactors as measured by the capacity factor. Capacity factors for the industry increased. from 57 percent in 1987 to 71 percent in $1992 .^{86}$

O\&M costs per MWe of capacity increased at an average rate of approximately 5 percent per year from 1981 through 1992 (Figure 9). From 1987 through 1992, while O\&M costs per $\mathrm{MWh}$ were declining slightly, O\&M costs per MWe were still showing modest increases. In other words, reductions in the cost of electricity generation were achieved primarily through increased output. Total O\&M costs, although they have leveled out somewhat (Figure 9), still need improvement. Further improvements in capacity factors have their limits, however, and the industry must concentrate on reducing the cost side of the O\&M equation.

Although the nuclear industry as a whole has relatively high O\&M costs, there are wide variations among individual power plants (Figure 10). For 1990 through 1992, 49 percent of U.S. nuclear power plants had average O\&M costs of $\$ 16.00$ or less per $\mathrm{MWh}$, and 26 percent had O\&M costs of $\$ 20.00$ or more. Because of this wide variation in O\&M costs, industry-level statistics can obscure the overall picture. Many plants are economically competitive and have good overall performance records. On the other hand, numerous plants are in trouble, and the possibility of early shutdowns is quite real. It has been estimated that 30 to 40 nuclear units are either already noncompetitive with the market price of power, or are in a position where any major capital expenditures could push them over the edge into noncompetitiveness. ${ }^{87}$

\section{Reasons for Increases in O\&M Costs}

Increases in $O \& M$ costs can be examined from two perspectives. What factors contributed to the increases and why did these factors occur? Publicly available data can be used to obtain some insight into the reasons for the rise in costs. For the most part, however, the Uniform System of Accounts is insufficient to quantify specific factors. Nevertheless, a number of factors have been cited in the literature and at industry conferences, and they can be summarized in a qualitative fashion.

\footnotetext{
${ }^{86}$ Energy Information Administration, Monthly Energy Review, March 1994, DOE/EIA-0035(94/03) (Washington, DC, March 1994), p. 103.

${ }^{87}$ Joe F. Colvin, "Nuclear Power: Meeting the Competitive Challenge," paper presented at the Fuel Cycle Conference, sponsored by the Nuclear Energy Institute (Boston, Massachusetts, March 20-23, 1994).
} 
Figure 9. Average Operating and Maintenance Costs per Megawatt-electric of U.S. Nuclear Capacity, 1981-1992

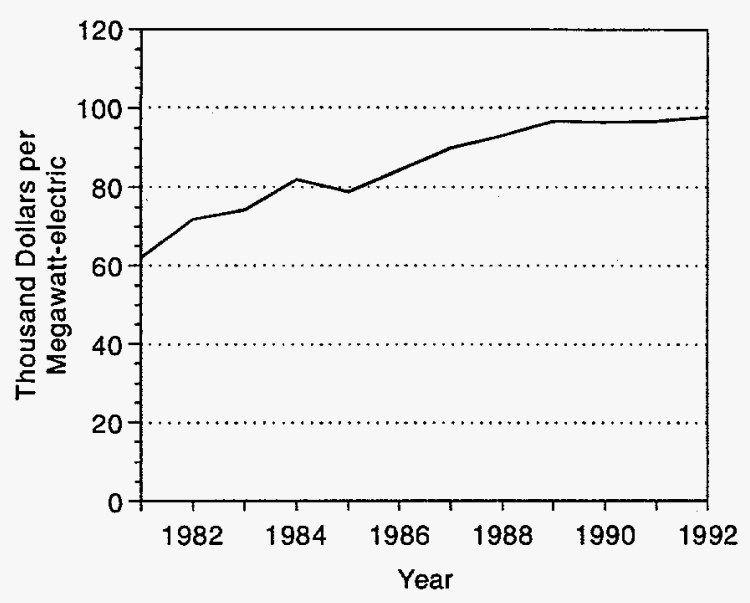

Notes: Costs are in 1992 dollars. Fuel costs are excluded. Source: Federal Energy Regulatory Commission, Form 1 (data obtained from the Utility Data Institute).

\section{What Factors Contributed to Increased O\&M Costs?}

Staff size is a large component of O\&M costs; it has been estimated that about two-thirds of O\&M costs are labor related. ${ }^{88}$ Industry-wide, the labor force per MWe of capacity has doubled over the past decade, from 0.31 employees per MWe in 1981 to $0.62 \mathrm{em}$ ployees in 1992 (Figure 11). This represents an average increase of 6 percent per year, which tracks closely with the 5-percent annual increase in O\&M costs per MWe. ${ }^{89}$ Much of the growth in staff levels occurred between 1981 and 1988 (Figure 11).

Contributing to staff growth have been enhanced security requirements, expanded training programs, the need for additional design work and system analyses, preventive maintenance programs, and additional design documentation and quality assurance programs. Every time a new requirement was imposed on a nuclear power plant, it meant more analyses, reviews, engineering, planning, and permits. ${ }^{90}$ Not only did

\section{Figure 10. Variation in Operating and Maintenance Costs for U.S. Nuclear Power Plants, 1990-1992}

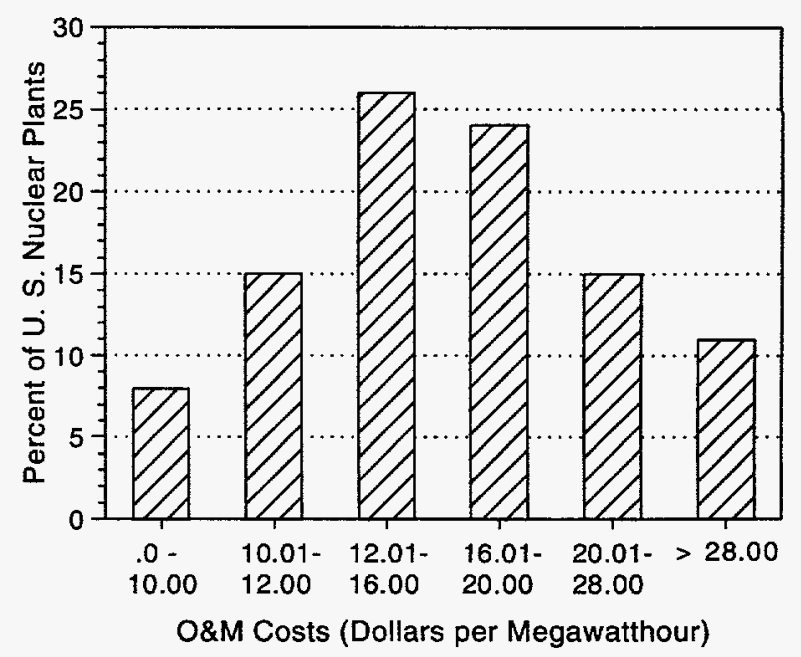

Notes: Costs are in 1992 dollars. Fuel costs are excluded. Source: Federal Energy Regulatory Commission, Form 1 (data obtained from the Utility Data Institute).

staff size grow, but real labor rates in the nuclear industry increased as well. Because O\&M costs are mostly labor related, the increase in real wages exacerbated the problem. ${ }^{11}$

A second reason for the increases in O\&M costs is plant outages. Industry-wide outage rates rose from 33.7 percent in 1981 to 36.7 percent in 1986, a 9-percent increase (Figure 12). Outages raise $O \& M$ costs by a combination of the loss of kilowatthours of generation during the time the plant is offline and the direct costs associated with performing work during the outage. During the early 1980's, when utilities were implementing safety improvements required by the U.S. Nuclear Regulatory Commission (NRC) after the accident at the Three Mile Island nuclear plant, both the duration of outages and the dollars spent contributed to the growth in O\&M costs. Since 1986, outage rates have been decreasing and capacity factors have been improving. This explains, in part, the leveling off of O\&M costs per MWh (Figure 8).

\footnotetext{
${ }^{88}$ Energy Information Administration, An Analysis of Nuclear Operating Costs: A 1991 Update, DOE/EIA-0547 (Washington, DC, May 1991), p. vii.

${ }^{89} \mathrm{~A}$ regression analysis of the relationship between O\&M costs per MW and employees per MW for 1981 through 1992 was statistically significant. The R-squared value was .44, indicating that 44 percent of the variation in O\&M costs per MW was explained by the number of employees per MW.

${ }^{90}$ Nuclear Management and Resource Council, Review of Operations and Maintenance Costs in the Nuclear Industry (December 1992), p. 19, and various papers presented at the Executive Conference on Controlling Nuclear Plant Operations and Maintenance Costs, sponsored by the American Nuclear Society (Newport Beach, CA, May 3-6, 1992).

${ }^{91}$ Energy Information Administration, An Analysis of Nuclear Operating Costs: A 1991 Update, DOE/EIA-0547 (Washington DC, May 1991 ), p. vii.
} 
Figure 11. Staff Size per Megawatt of U.S. Nuclear Plant Capacity, 1981-1992

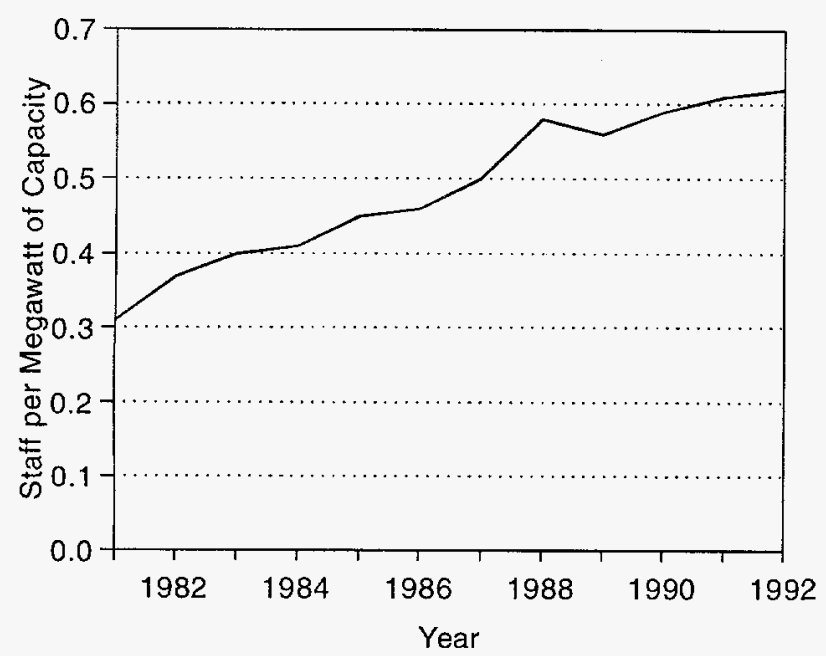

Source: Federal Energy Regulatory Commission, Form 1 (data obtained from the Utility Data Institute).

\section{Why Did These Factors Occur?}

The underlying reasons for increased staffing and higher outage rates at nuclear power plants are difficult to quantify and sometimes controversial. There is, however, some consensus among observers of the industry that the regulatory environment in which plants operate is a major determinant of O\&M requirements. The number of regulatory guidelines adopted by the NRC rose sharply in the mid 1970's and again in the early 1980's after the Three Mile Island accident. In 1980 , there were approximately 1,900 regulatory guides and revisions; in 1992, there were nearly $3,500 .{ }^{92}$

In addition, the NRC moved from primarily regulating construction of nuclear plants to almost exclusively regulating their operation. Thus, it formulated measures of compliance with safety standards, such as the Systematic Assessment of License Performance (SALP) ratings and. the concept of the "troubled plant" or "Watch List," both of which have high public visibility.

Utility response to NRC regulatory requirements and enforcement actions meant increases in staff hiring and training, additional testing and monitoring of components and equipment, additional tracking and reporting of various equipment and systems in the
Figure 12. Annual Outage Rates of the U.S. Nuclear Industry, 1981-1992

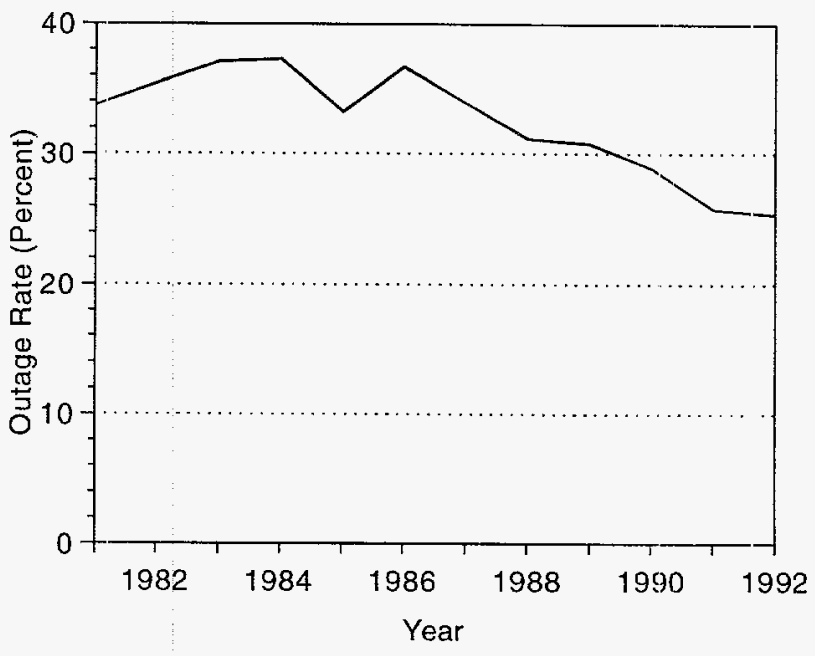

Source: U.S. Nuclear Regulatory Commission, Licensed Operating Reactors: Status Summary Report (NUREG-0020), (Washington, DC, December 1992)

plant, and replacement and repair of defective and questionable equipment-all of which affect C\&M costs.

On the other hand, ascribing costs increases to meeting NRC regulatory requirements and enforcement is risky and can be overstated or misleading. In many instances, it is difficult to establish exact reasons for increases in utility staff levels, which may have occurred because of an NRC regulation or simply because they made sense in terms of improved safety or improved operation. One study estimated that NRC regulatory requirements and enforcement efforts accounted for as much as 58 percent of the escalation in O\&M costs for 1974 through $1987 .^{93}$ This estimate has shortcomings, however, because the analysis model did not separate the effect of regulations on O\&M costs over time from other factors that may also have affected costs over time. The 58-percent estimate can perhaps be viewed as an upper limit on the impact of NRC regulations on O\&M costs.

Other causes for increased O\&M costs can be classified as behavioral-as opposed to programmatic-and are related to managers' attitudes toward operation of a nuclear plant. Striving for perfection, poor work ethic, and problems with inefficient organizational structures have been cited as partial explanations for increased

${ }^{92}$ F. W. Griffels and S. K. Parker, "Looking Introspectively at Nuclear O\&M Expenses," paper presented at the Executive Conference on Controlling Nuclear Plant Operations and Maintenance Costs, sponsored by the American Nuclear Society (Newport Beach, CA, May 3-6, 1992.)

${ }^{93}$ Energy Information Administration, An Analysis of Nuclear Operating Costs: A 1991 Update, DOE/EIA-0547 (Washington DC, May 1991), p. ix. 
costs. ${ }^{94}$ Another argument is that management of the plants is a problem. This argument points to the fact that there is such a wide variation in O\&M costs across the U.S. nuclear power industry. According to this argument, the reasons that some plants with performance records equivalent to those of other, similar plants have staffs double or triple the size of those other plants is that there was lack of effective management in the process. ${ }^{95}$ However, there have been no rigorous attempts to define the effects of management action or inaction on $O \& M$ costs.

\section{Efforts to Reduce O\&M Costs}

High O\&M costs-coupled with mediocre performance for many reactors, potential capital repairs, and relatively low replacement costs-could result in the premature retirement of some units. ${ }^{96}$ In response, a number of broad-based industry-wide programs to help control and possibly reduce O\&M costs have been started in the past few years. Also, individual utilities, recognizing their problems, have begun to focus on cost reduction activities. Utilities must examine thousands of activities and processes to make each one more efficient and to extract cost savings bit by bit.

\section{Industry-Wide Initiatives}

Recognizing escalating O\&M costs, some utilities, vendors, and industry groups developed a strategic plan which outlines a number of programs to reduce costs and assigns organizational responsibility for their implementation. ${ }^{97}$ The plan formulates three main goals: (1) improve the operational cost-effectiveness of individual utilities, (2) improve interactions with external entities, and (3) improve regulations and the regulatory process.
One of the major initiatives specified in the plan is the sharing of information on cost-effective practices. Clearly, less efficient plants could benefit from the experience of plants with low O\&M costs and high levels of performance. This approach is similar to industry initiatives aimed at improving reactor capacity factors. For example, the Institute for Nuclear Power Operations has a program to assist utilities in exchanging information about cost-effective procedures by arranging cooperative relationships between plants or plant groups.

\section{Utility-Level Initiatives}

A number of programs are being introduced at the utility level to improve management functions. The focus of many of the programs is to increase worker involvement and responsibility and to bring management closer to the worker level by decreasing the layers of management overhead. Improving worker morale, increasing worker participation, and fostering a sense of pride are viewed as critical. ${ }^{98}$ In some companies, steps are being taken to ensure that management will be more focused on the operation of the plant and less on other corporate activities. For example, Kansas Gas and Electric has established an operating company, Wolf Creek Nuclear Operating Company, to run the Wolf Creek nuclear unit. ${ }^{99}$

Some utility managers are introducing modern management tools to improve the quality and timeliness of management information, and to help them operate their plants more effectively. For example, improved cost accounting methods have been implemented that will allow management to ascertain costs for individual jobs, providing the basis for close supervision of O\&M

\footnotetext{
${ }^{94}$ Nuclear Management and Resource Council, Review of Operations and Maintenance Costs in the Nuclear Industry (December 1992), p. 19 , and various papers presented at the Executive Conference on Controlling Nuclear Plant Operations and Maintenance Costs sponsored by the American Nuclear Society (Newport Beach, CA, May 3-6, 1992).

${ }^{95}$ Andrew C. Kadak, Yankee Atomic Electric Co., "Is Technology Enough--What About Management?" Nuclear News, Vol. 37, No. 2 (February 1994), pp. 37-40.

${ }^{96}$ Rancho Seco, Trojan, La Crosse, Yankee Rowe and Unit 1 of the San Onofre plant were retired from service before their operating licenses expired.

${ }^{97}$ United States Council for Energy Awareness (USCEA), Nuclear Management and Resources Council (NUMARC), Edison Electric Institute (EEI), Electric Power Research Institute (EPRI), and the Institute for Nuclear Power Operators (INPO) et al., Strategic Plan For Improved Economic Performance (October 1993). In March 1994, the USCEA, NUMARC, and the nuclear portion of the EEI were combined into the Nuclear Energy Institute.

${ }^{98}$ F. W. Griffels and S. K. Parker, "Looking Introspectively at Nuclear O\&M Expenses," paper presented at the Executive Conference on Controlling Nuclear Plant Operations and Maintenance Costs, sponsored by the American Nuclear Society (Newport Beach, CA, May 3-6, 1992), pp. 8-12 and 16-27.

${ }^{99}$ Kent R. Brown, "Maximize the Affirmative," paper presented at the Executive Conference on Controlling Nuclear Plant Operations and Maintenance Costs, sponsored by the American Nuclear Society (Newport Beach, CA, May 6, 1992 ), p. 3.
} 
activities. ${ }^{100}$ Preventive maintenance programs incorporating statistical reliability techniques are also being used to supplement or replace vendor estimates of failure time in an effort to determine the optimal balance between preventive and corrective maintenance. ${ }^{101}$

Establishing aggressive job-oriented time and budgetary goals is also being used as an effective management tool. For example, many utilities are setting goals for reducing the length of refueling outages, with emphasis on trying to surpass previous records. ${ }^{102}$ Goal setting establishes an objective that is highly visible to management and the public, fosters teamwork among workers, and provides a tangible measure that management can use to reward workers and increase morale.

Inventory costs are another area where management is finding considerable fat to trim. Some utilities have built up large inventories of spare parts, some of them are obsolete, that entail considerable carrying costs and tie up valuable capital. ${ }^{103}$

In combination with improved procedures, some utilities are now taking a hard look at staffing levels, and several have already implemented programs to "rightsize" their plants. Operational environment and manpower requirements are being reviewed, with the objective of eliminating excess staff by consolidating functions, implementing efficiency procedures, and eliminating unnecessary activities. For example, in 1991 Florida Power \& Light (FPL) reorganized and consolidated its operation, resulting in a reduction in force of 900 nuclear workers. FPL has announced that more potential layoffs are likely in an effort to reduce O\&M costs by $\$ 100$ million. Philadelphia Electric Company (PECO) also has plans to eliminate nearly 20 percent of its 3,400 person nuclear staff, based on the recommen- dations of a 6-month study completed in fall 1992. Estimated savings of $\$ 35$ to $\$ 38$ million in operating costs are expected to begin in fiscal year $19950^{104}$

\section{Cost Reduction Through Increased Electricity Generation}

O\&M costs per MWh can be reduced by lowering O\&M costs or by improving plant performance. Industry efforts to improve capacity factors began showing results around 1987, when the industry-wide average broke the 60-percent barrier for the first time since 1980 . In 1992, the average capacity factor for U.S. power plants was 70.9 percent. ${ }^{105}$ The result, as noted earlier, has been a decrease in real O\&M costs per MWh over the past few years. Any additional increase in capacity factors would further reduce O\&M costs per MWh; however, most of the beneficial effect on O\&M costs from the capacity factor improvement program has probably already been seen.

\section{Initiatives to Reduce the Effects of Regulation on Costs}

In the past several years, the NRC has become more concerned about the impact of its regulations on costs, and in January 1993, established a Regulatory Review Group (RRG) with the aims of identifying areas to reduce the regulatory burden on nuclear utilities and strengthening NRC administrative practices. ${ }^{106}$ The RRG recommended more than 60 areas for changes in regulatory procedures, many of which could significantly reduce industry costs without adversely affecting the level of safety at operating plants. For example, the RRG suggested using more performance-based and risk-based approaches in such areas as quality assurance, security, fire protection, and in-service inspection and testing. ${ }^{107}$

\footnotetext{
${ }^{100}$ Bill Kuh, "Cost Performance at Tennessee Valley Authority," pp. 4-6, and Stephen Parker, "Looking Introspectively at Nuclear Operating and Maintenance Expenses," pp. 8-12, papers presented at the Executive Conference on Controlling Nuclear Plant Operations and Maintenance Costs sponsored by the American Nuclear Society (Newport Beach, CA, May 3-6, 1992).

${ }^{101}$ Steven E. Kuehn, "Reliability-Centered Maintenance Trims Nuclear Power Plant Costs," Power Engineering (August 1992).

102"Outage Management," Nuclear News (April 1994), pp. 36-51.

${ }^{103}$ Gerald B. Slade, "Issues Surrounding the Management of O\&M Costs," paper presented at the Executive Conference on Controlling Nuclear Plant Operations and Maintenance Costs, sponsored by the American Nuclear Society (Newport Beach, CA, May 4, 1992 ), F. 6.

104"FP\&L to Trim 1994 O\&M Spending by \$100-Million, Layoffs Expected" (July 15, 1993), p. 12. "PECO Begins Cuts, Reassignments to Trim Nuclear Group by 20 Percent," Nucleonics Week (April 22, 1993), pp. 4-5.

${ }^{105} \mathrm{~A}$ recent EIA analysis reviewed the factors contributing to poor capacity factors in the early 1980 s and the reasons for their improvement to current levels. Bill Liggett and Kenneth Wade, "Improvements in Nuclear Power Capacity Factors," Electric Power Monthly, DOE/EIA-0226(93/02) (Washington, DC, February 1992).

${ }^{106}$ U.S. Nuclear Regulatory Commission, Policy Issue (Information), SECY-94-003 (January 7, 1994).

${ }^{107} \mathrm{~A}$ performance-based approach emphasizes the NRC's evaluation of results of reactor activities, instead of using prescriptive requirements. The advantage is that the performance-based method allows the operators of a nuclear plant to devise the most effective means to satisfy the requirements. A risk-based approach refers to the use of statistical probability techniques to help estimate equiprient or component failure rates, in order to reduce the frequency of monitoring and testing of components.
} 
The NRC has also initiated a Cost Beneficial Licensing Program (CBLP) to give special attention to licensing actions with high cost value (to the nuclear plant) that would otherwise have a low review priority within the NRC. ${ }^{108}$ In many instances, the managers of nuclear plants believe that they have made "overcommitments" to meet regulatory requirements and that revisions to those commitments could result in cost savings. This program, by attempting to give higher priority to such concerns, is an example of the NRC's increased sensitivity to the economic implications of its regulations.

\section{Technological Improvements}

Technological improvements offer the opportunity to reduce costs by providing more reliable equipment, better diagnostic testing, reduction of worker exposure, and longer component life. Thus, it is important for utilities to share information on technological improvements. The Electric Power Research Institute (EPRI) is currently sponsoring a pilot program on O\&M cost reduction involving three utilities, with emphasis on collaboration among the utilities, sharing of information, and transfer of technology.

Examples of areas in which technological improvements have already been made ${ }^{109}$ are:

- Piping repair in boiling-water reactors

- Use of non-cobalt-bearing parts to reduce worker exposure to radiation

- Use of demineralized resins to prolong heat exchanger life

- Instrument calibration reduction programs

- Erosion/corrosion control and monitoring programs

- Buried pipe inspection/repair programs

- Improved steam-generator chemistry to prolong steam generator life

- Improved motor-operated valves.

\section{Statistical Analysis of O\&M Costs for U.S. Nuclear Power Plants}

For a more detailed look at trends in nuclear O\&M costs, a statistical analysis of the costs for individual plants by size and age was conducted. To mitigate the effect of refueling outages and to smooth out some of the variation in year-to-year O\&M costs, much of the analysis was based on costs averaged over 3-year intervals. A plant had to be operating in each year of a 3year interval to be included.

\section{Costs Trends for 3-Year Intervals}

The trend to higher O\&M costs for many of the plants is clear. Approximately 40 percent of the 48 plants operating over the 3 years from 1981 through 1983 had average O\&M costs below $\$ 10.00$ per MWh (Figure 13). From 1984 through 1986 only 23 percent of the units had average costs below $\$ 10.00$ per MWh, and from 1987 through 1989 only 9 percent had such low costs. The median O\&M cost from 1990 through 1992 was about $\$ 16.00$ per MWh, compared with about $\$ 13.00$ per MWh from 1981 through 1983-an increase of nearly 25 percent.

Figure 13. Cumulative Percentage of U.S. Nuclear Plants at Different Cost Levels, by 3-Year Groups, 1981-1992

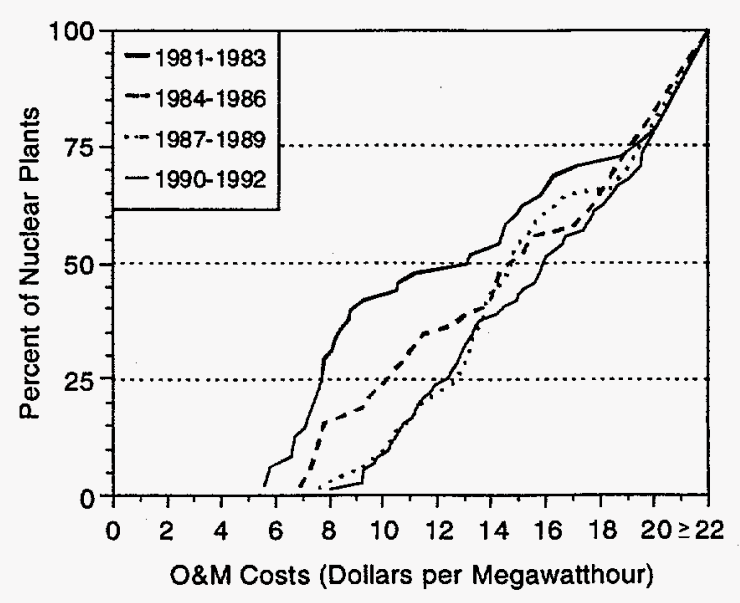

Notes: Costs are in 1992 dollars. Fuel costs are excluded. Source: Federal Energy Regulatory Commission, Form 1 (data obtained from the Utility Data Institute).

\footnotetext{
${ }^{108}$ U.S. Nuclear Regulatory Commission, "Priority Determination for NRR Review Efforts," Memorandum (June 6, 1993) and "Costs Beneficial Licensing Actions," Memorandum (September 17, 1993).

${ }^{109}$ Norris S. Hirota, “O\&M Cost Control Activities at Palo Verde Nuclear Generating Station. Part II. Impact of Technology: EPRI O\&M Cost Reduction Pilot Program," paper presented at the Executive Conference on Controlling Nuclear Plant Operations and Maintenance Costs, sponsored by the American Nuclear Society (Newport Beach, CA, May 6, 1992), pp. 3-45.
} 


\section{Comparison of Costs by Size of Plant}

For the purpose of this analysis, small plants are defined as those with a capacity of less than 800 megawatts (MW), mid-size plants as those with a capacity greater than or equal to $800 \mathrm{MW}$ and less than $1,200 \mathrm{MW}$, large plants as those with a capacity greater than or equal to $1,200 \mathrm{MW}$ and less than 2,000 MW, and very large plants as those with a capacity of at least 2,000 MW. All of the small plants are single-unit, older plants. With the exception of Point Beach and Prairie Island, all of the mid-size plants are single-unit plants. The large plants include both single and multiunit plants. All of the very large plants include more than one unit.

$\mathrm{O} \& \mathrm{M}$ costs, on average, tend to be lower for larger plants. In the 1990 through 1992 interval, the median O\&M cost for small plants was slightly less than $\$ 20.00$ per MWh (Figure 14), compared with about $\$ 16.00$ per MWh for mid-size and large plants, and about $\$ 12.00$ per MWh for very large plants. It appears that larger plants benefit from economies of scale, especially with regard to manpower needs for such activities as engineering design, security, responding to paperwork requirements, and other activities for which staffing levels do not depend on plant size. Plant vintage may also play a role, since the smaller plants, as a group, are older than the larger plants. The larger, newer plants

Figure 14. Cumulative Percentage of U.S. Nuclear Plants at Different Cost Levels, by Plant Size, 1990-1992

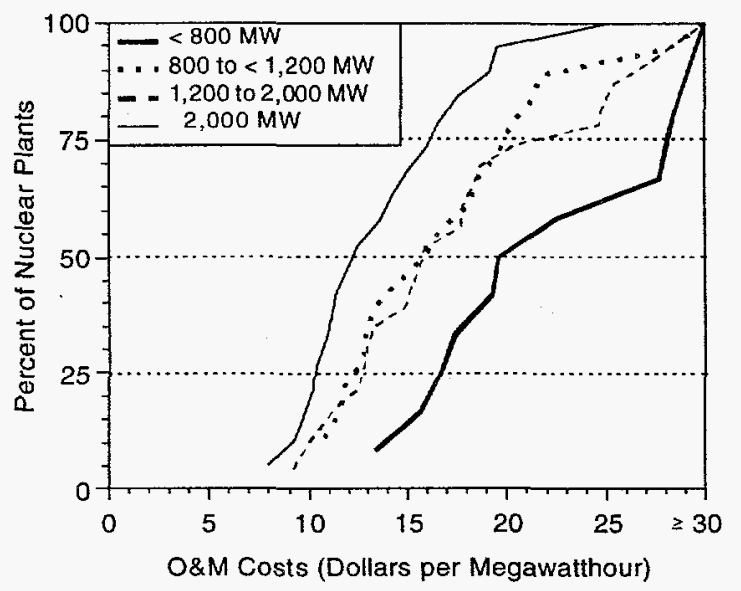

Notes: Costs are in 1992 dollars. Fuel costs are excluded. Source: Federal Energy Regulatory Commission, Form 1 (data obtained from the Utility Data Institute). may have benefitted from lessons learned in older plants. In addition, they were brought on line with improved equipment and components and in compliance with stricter NRC regulations.

\section{Comparison of Costs by Age of Plant}

For this analysis, plant age is defined as the age of the oldest reactor in the plant as of 1992. Plants 12 years old or younger in 1992 are referred to as new plarits, and plants over 12 years old are referred to as old plants. New plants, as defined here, came on-line after the Three Mile Island accident in 1979. Because that accident was obviously significant to the industry and resulted in substantial changes, it is used as the demarcation point for the new and old plant groups.

From 1990 through 1992, newer plants operated at a significantly lower average cost level than old plants: 50 percent of the new plants had average O\&M costs of $\$ 13.00$ per $\mathrm{MWh}$ or less, whereas 50 percent of the older plants had average costs of $\$ 18.00$ per MWh or less (Figure 15). The mean O\&M cost for the new plants from 1990 through 1992 was $\$ 13.41$ per MWh, or about 25 percent lower than the mean cost of $\$ 17.41$ per MWh for the old plants. While this suggests a positive correlation between O\&M costs and plant age, a more complete picture is obtained by looking at costs by both age and size groupings.

\section{Figure 15. Cumulative Percentage of U.S. Nuclear Plants at Different Cost Levels, by Age Group, 1990-1992}

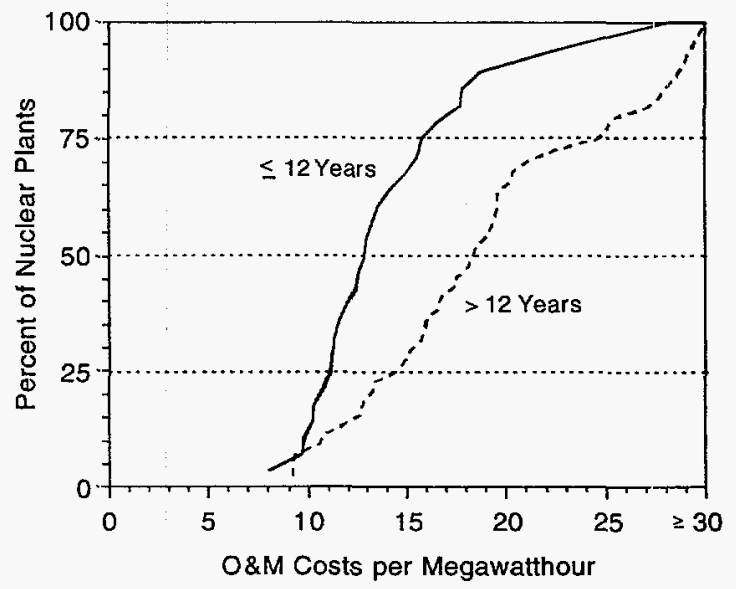

Notes: Costs are in 1992 dollars. Fuel costs are excluded.

Source: Federal Energy Regulatory Commission, Form 1 (data obtained from the Utility Data Institute). 


\section{Comparison of Costs by Age and Size of Plant}

From 1990 through 1992, the small plants in the analysis were old (all but one were more than 18 years old), and had relatively high O\&M costs (Table 23). For the mid-size plants, there was little or no difference in average costs (about $\$ 17.00$ per MWh) for old and new plants. For the large and very large groups, there was a noticeable difference in O\&M costs by age category. The average O\&M cost for older large plants was $\$ 17.34$ per $\mathrm{MWh}$ compared with $\$ 15.04$ per MWh for the newer large plants. The difference was even greater, $\$ 15.98$ vs. $\$ 11.72$, for the very large plants. This analysis helps to confirm what the industry-wide data suggested-that both age and size are related to O\&M costs-the larger and newer the plants, the lower the costs.

It is important to note that the correlation of size to O\&M costs holds for both the older and newer plants in the analysis. Although they have higher average costs than those for the new plants, the old plants also show a significant decrease in average costs as the size of the plant increases-from $\$ 21.61$ per MWh for the small plants to $\$ 15.98$ per $\mathrm{MWh}$ for the very large plants (Table 23). For new plants, the average costs range from $\$ 16.59$ per MWh for mid-size plants to $\$ 11.72$ per MWh for very large plants. Thus plant size appears to be a more important determinant of O\&M costs than does the age of the plant.

\section{O\&M Costs by Age in Year of Observation}

In the above discussion, "plant age" was defined as the age of the plant in 1992 (which is a static property of the plant), in order to facilitate comparisons between older and newer plants in the 1990 through 1992 period. Because the nuclear plants were built at different times, with improvements in design and equipment being implemented on the newer reactors, the comparison of O\&M costs based on plant age as of 1992 is actually between different vintages of nuclear plants. In this section, "plant age" is defined as the age of the plant at the time the O\&M costs were incurred. The point of this analysis was to determine whether $O \& M$ costs increased as a result of age-related degradation: Do the costs of operating a plant increase because the components and equipment in the plant deteriorate over time, requiring additional maintenance and/or replacement of components? Because the cost data come from different time periods, a bias may be introduced in O\&M costs over time for reasons not related to age degradation. To compensate for this possibility, the data were adjusted in an attempt to eliminate the effects of time. ${ }^{110}$

From 1981 through 1992, most of the plants used in the analysis were less than 23 years old. For those plants, there does not appear to be any trend in O\&M costs associated with aging, with the notable exception of plants in the 800- to 1,200-MW size grouping (Figure 16). For the small plants (less than $800 \mathrm{MW}$ ) and the large to very large plants $(1,200$ to $>2,000 \mathrm{MW}), \mathrm{O} \& \mathrm{M}$ costs fluctuated across the 2- to 22-year age range. For the mid-size plants, however, there was a fairly steady decrease in O\&M costs from 8 through 22 years of age. This trend is just the opposite of what would be expected if age-related degradation were contributing to O\&M costs. Although this is a very limited analysis, a preliminary conclusion is that increases in O\&M costs due to aging have not occurred in the U.S. nuclear power industry. On the other hand, U.S. nuclear power plants are licensed by the NRC to operate for 40 years,

Table 23. Comparison of Average U.S. O\&M Costs by Age and Plant Size, 1990-1992 (Dollars per Megawatthour)

\begin{tabular}{c|c|c|c|c|c}
\hline & \multicolumn{5}{|c}{ Plant Size Groupings (Megawatt-electric) } \\
\cline { 2 - 6 } Age Group (Years) & $\begin{array}{c}\text { Small } \\
(<800)\end{array}$ & $\begin{array}{c}\text { Mid-Size } \\
(800 \text { to }<1,200)\end{array}$ & $\begin{array}{c}\text { Large } \\
(1,200 \text { to }<2,000)\end{array}$ & $\begin{array}{c}\text { Very Large } \\
(>=2,000)\end{array}$ & All Sizes \\
\hline New $(\leq 12) \ldots \ldots \ldots \ldots \ldots$ & - & $16.59(7)$ & $15.04(9)$ & $11.72(12)$ & $13.14(28)$ \\
Old $(>12) \ldots \ldots \ldots \ldots$ & $21.61(12)$ & $16.80(11)$ & $17.34(14)$ & $15.98(7)$ & $17.41(44)$ \\
All Ages $\ldots \ldots \ldots \ldots \ldots$ & $21.61(12)$ & $16.71(18)$ & $16.59(23)$ & $13.03(19)$ & $15.35(72)$ \\
\hline
\end{tabular}

$--=$ No plants in this category.

Notes: Costs are in 1992 dollars. Fuel costs are excluded. Number of plants in each group is shown in parentheses.

Source: Federal Energy Regulatory Commission, Form 1 (data obtained from the Utility Data Institute).

${ }^{110}$ The ratio of the average costs in each year to the average costs in 1992 was used as an adjustment factor for plant-level costs. 
Figure 16. Operating and Maintenance Costs of U.S. Nuclear Power Plants, by Age and Size Groups, 1981-1992

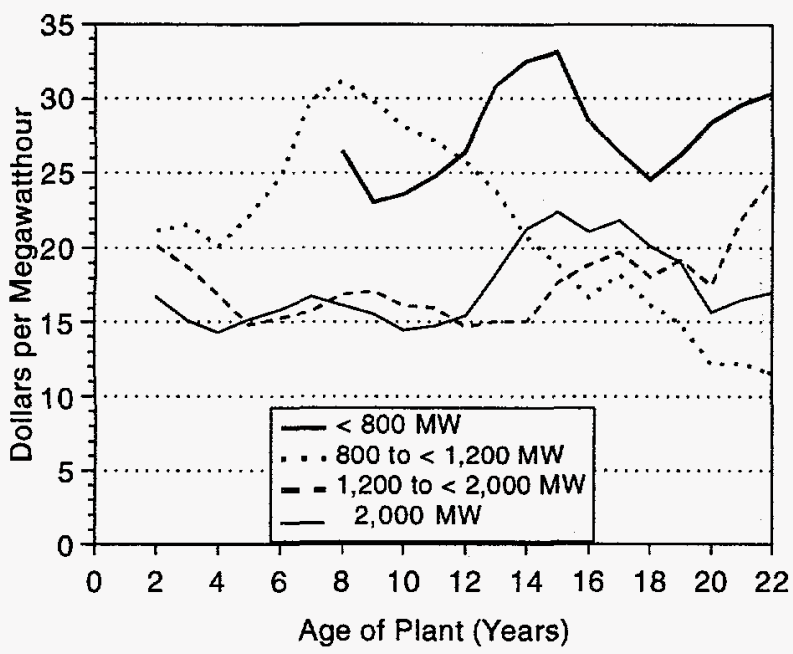

Notes: Costs have been adjusted to account for time. Fuel costs are excluded. This is a 3-year moving average.

Source: Federal Energy Regulatory Commission, Form 1 (data obtained from the Utility Data Institute).

and when the plants are closer to 40 years old, the picture of O\&M costs may change.

\section{Capacity Factors of U.S. Nuclear Power Plants}

As noted previously in this Chapter, higher capacity factors have contributed to lower O\&M costs per MWh. In that regard, it is important for U.S. reactors to continue the trend in improving their capacity factors. The following section presents an update on the performance of U.S. reactors.

In 1993, domestic nuclear reactors continued to operate well. The annual average capacity factor for U.S. nuclear power plants was 70.5 percent for 1993 (Figure 17), slightly lower than the 1992 value of 70.9 percent. ${ }^{111}$ In 1993, 70 percent of the nuclear units operating in the United States had capacity factors above the average of 70.5 percent. As of December 1993, there were 109 operable reactors in the United States. Although Browns Ferry 1 and 3 are considered as operable, they have been out of service since 1985 . Comanche 2, having received its operating license in
Figure 17. U.S. Nuclear Power Plant Average Capacity Factors, 1975-1993

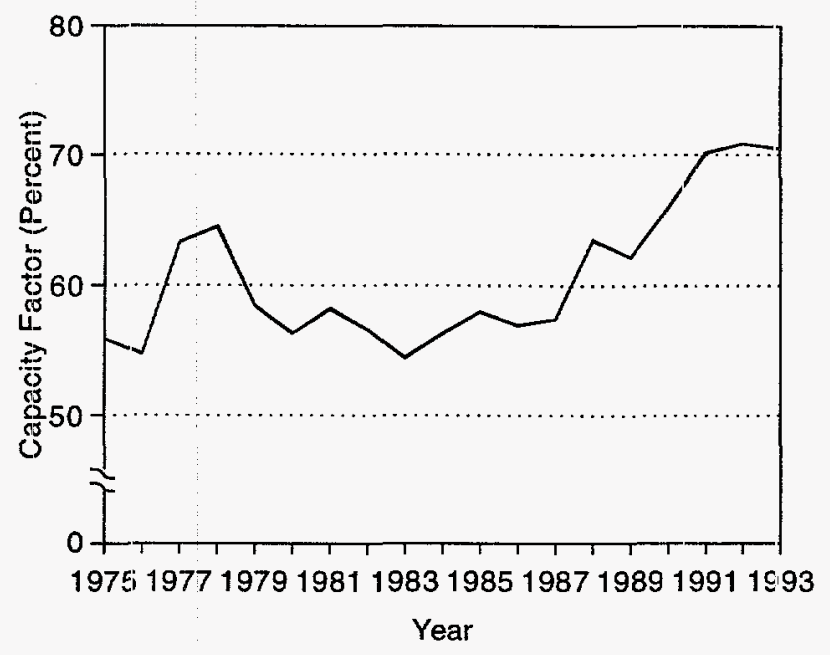

Source: Energy Information Administration, Monthly Energy Review, DCE/EIA-0035 (94/106), June 1994.

April 1993, is the first new reactor to come on-line in the past 3 years.

Capacity factors are a measure of a reactor's performance. In the category of "highest capacity factor for 1993," the top 10 U.S. nuclear reactors all operated with capacity factors above 96 percent. In 1992, only 6 of the top 10 shared that distinction. In some cases, capacity factors may be greater than 100 percent, because the capacity factor is computed from an estirnated reactor capacity, and occasionally reactors operate beyond their estimated capacity.

Under "highest lifetime capacity factors," the following six reactors were among the top ten performers in 1992. ${ }^{112}$ and 1993: Point Beach 2, Prairie Island 1 and 2, Hope Creek, Kewaunee, and Callaway 1 (Table 24). Prairie Island 1 and 2, Point Beach 2, and Kewaunee have operated for more than 17 years. The average operating life of the other six top performers is 5 years.

One of the factors that influences a reactor's capacity factor is its outage rate, or the percentage of time the reactor is not generating electricity. The outage rates for U.S. reactors have been steadily dropping, from 36.7 percent in 1986 to 25.4 percent in 1992. In 1993, however, the U.S. average rate increased to 26.2 percent. The top 10 reactors with the lowest lifetime

\footnotetext{
${ }^{111}$ Energy Information Administration, Monthly Energy Review March 1994, DOE/EIA-0035(94/03) (Washington, DC, March 1994), p. 103.

${ }^{112}$ Energy Information Administration, World Nuclear Capacity and Fuel Cycle Requirements 1993, DOE/EIA-0436(93) (Washington, DC, November 1993), p. 65.
} 
Table 24. U.S. Nuclear-Generating Units Achieving the Best Performance Records as of December 31, 1993

\begin{tabular}{c|c|c|c|c}
\hline & Operating Utility & Reactor Type & $\begin{array}{c}\text { Year of Initial } \\
\text { Operation a }\end{array}$ & $\begin{array}{c}\text { Capacity Factor } \\
\text { (percent) }\end{array}$ \\
\hline
\end{tabular}

\section{Highest Lifetime Capacity Factors}

1. Limerick $2 \ldots \ldots \ldots \ldots \ldots$. . . . Philadelphia Electric Co.

2. Point Beach $2 \ldots \ldots \ldots \ldots$. . . . . Wisconsin Electric Power Co.

3. Prairie Island $2 \ldots \ldots \ldots$. . . . . Northern States Power Co.

4. Hope Creek $1 \ldots \ldots \ldots \ldots$. . . Public Service Electric \& Gas Co.

5. Kewaunee ............. Wisconsin Public Service Corp.

6. Prairie Island $1 \ldots \ldots \ldots \ldots$. . . . . . . .

7. Callaway $1 \ldots \ldots \ldots \ldots$ Union Electric Co.

8. Waterford $3 \ldots \ldots \ldots \ldots$ Louisiana Power \& Light Co.

9. Seabrook $1 \ldots \ldots \ldots \ldots \ldots$. Public Service Co. of $\mathrm{NH}$

10. Vogtle $2 \ldots \ldots \ldots \ldots \ldots \ldots$ Georgia Power

Highest Capacity Factors for 1993

1. Calvert Cliffs $1 \ldots \ldots \ldots$. . . . . Baltimore Gas \& Electric Co.

2. Donald C. Cook $1 \ldots \ldots$. . . . Indiana/Michigan Power Co.

3. Shearon Harris $1 \ldots \ldots \ldots$. Carolina Power \& Light Co.

4. Oconee $3 \ldots \ldots \ldots \ldots \ldots$..... Duke Power Co.

5. Arkansas Nuclear $2 \ldots \ldots \ldots$ Arkansas Power \& Light Co.

6. Hope Creek $1 \ldots \ldots \ldots$. . . . . . Public Service Electric \& Gas Co.

7. Prairie Island $1 \ldots \ldots \ldots \ldots$ Northern States Power Co.

8. Waterford $3 \ldots \ldots \ldots \ldots \ldots$ Louisiana Power \& Light Co.

9. Turkey Point $3 \ldots \ldots \ldots$. . . . . Fiorida Power \& Light Co.

10. Joseph M. Farley $1 \ldots \ldots$. . . Alabama Power Co.

Lowest Lifetime Forced Outage Rates ${ }^{b}$

$\begin{array}{lrr}\text { PWR } & 1974 & 100.9 \\ \text { PWR } & 1974 & 100.0 \\ \text { PWR } & 1987 & 99.9 \\ \text { PWR } & 1974 & 99.8 \\ \text { PWR } & 1978 & 97.7 \\ \text { BWR } & 1986 & 97.7 \\ \text { PWR } & 1974 & 97.4 \\ \text { PWR } & 1985 & 97.0 \\ \text { PWR } & 1972 & 97.0 \\ \text { PWR } & 1977 & 96.6\end{array}$

Wisconsin Electric Power Co.

1. Point Beach $2 \ldots \ldots \ldots \ldots \ldots \ldots$ Wisconsin Electric

$\begin{array}{lll}\text { BWR } & 1989 & 88.3 \\ \text { PWR } & 1973 & 85.3 \\ \text { PWR } & 1974 & 84.9 \\ \text { BWR } & 1986 & 84.4 \\ \text { PWR } & 1973 & 84.3 \\ \text { PWR } & 1974 & 84.3 \\ \text { PWR } & 1984 & 83.8 \\ \text { PWR } & 1985 & 83.2 \\ \text { PWR } & 1990 & 82.9 \\ \text { PWR } & 1989 & 82.4\end{array}$

3. Monticello ... . . . . . . . . . . . Northern States Power Co.

4. Point Beach $1 \ldots \ldots \ldots \ldots$. . . Wisconsin Electric Power Co.

5. Kewaunee ................ Wisconsin Public Service Corp.

6. Byron $1 \ldots \ldots \ldots \ldots$. . . . . Commonwealth Edison Co.

7. Callaway $1 \ldots \ldots \ldots \ldots \ldots$ Union Electric Co.

8. Diablo Canyon $1 \ldots . . \ldots$. . . . Pacific Gas \& Electric Co.

9. Byron $2 \ldots \ldots \ldots \ldots \ldots$ Commonwealth Edison Co.

10. Haddam Neck . . . . . . . . . . . Connecticut Yankee Atomic Power Co.

\footnotetext{
aYear of Initial Operation is the date the unit received its full-power license.

${ }^{b}$ Represents only unscheduled downtime (excludes refueling and scheduled maintenance).

$B W R=$ boiling-water reactor.

PWR = pressurized-water reactor.

Note: Only reactors that had operated for at least three complete fuel cycles by December 31, 1993, are listed.

Source: U.S. Nuclear Regulatory Commission, Licensed Operating Reactors: Status Summary Report (NUREG-0020) (Washington, DC, January through December 1993).
}

forced outage rates in 1993 were the same as those in 1992 with the exception of Vogtle 2, which replaced Prairie Island 2.

This section looks at reactor performance by age for the 104 reactors that operated past their first cycle, for the full 3-year period, 1991 through 1993. We define new nuclear units as those that are equal to or less than 12 years of age and old nuclear units as those greater than 12 years old. The average capacity factor of the new units is 75.2 percent (Table 25), appreciably higher than the average capacity factor of 67.6 percent for the old units. Both the old and new units performed better over the 1991 through 1993 period than over the 1990 through 1992 period. The 21 reactors in the 6 to 9 year age group, with an average capacity factor of 77.2 
Table 25. Number and Percent of U.S. Nuclear Units at Different Capacity Factor Levels by Age Group, 1991 to 1993

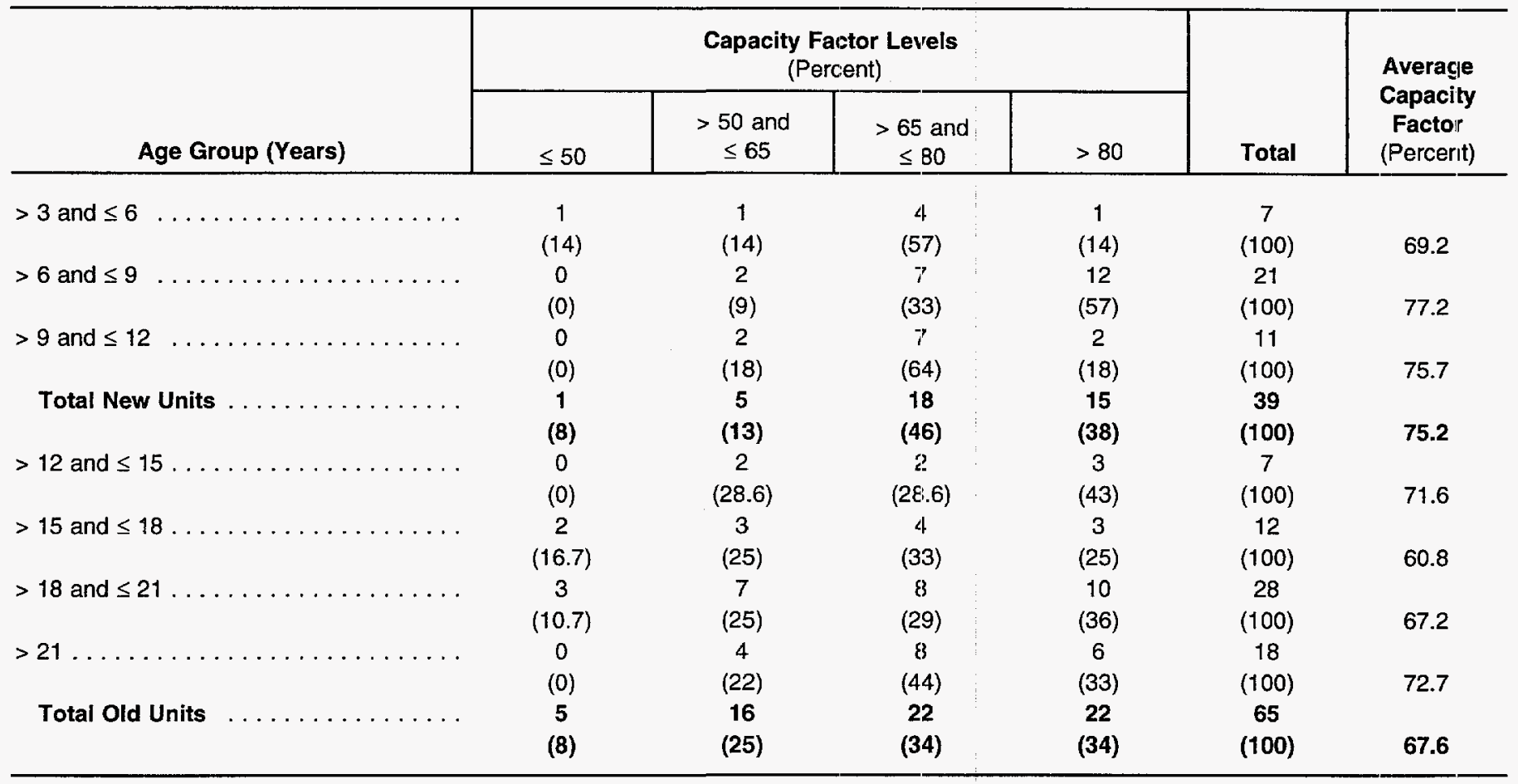

Note: Number in parentheses indicates the percent of reactors for the age group.

Source: U.S. Nuclear Regulatory Commission, Licensed Operating Reactors: Status Summary Report (NUREG-0020) (Washington, D.C. December 1993).

percent, performed better than any of the age groupings. The improved reactor performance results from advanced technology and from the operating experience gained by managers of the older nuclear units.

In analyzing capacity factors by reactor size, we group the reactors as follows: small is less than or equal to $700 \mathrm{MW}$; medium is greater than or equal to 701 and less than or equal to $1,000 \mathrm{MW}$; and large is greater than or equal to 1,001 MW. The average capacity factor over the period 1991 through 1993 for the three size groupings ranges from 69.2 percent for the large units to 76.1 percent for the small units (Figure 18). The medium-sized units have an average capacity factor of 72.3 percent.

\section{Comparison with Foreign Reactors}

Worldwide, the countries with the highest historical annual capacity factors for commercial nuclear power plants are Finland, Argentina, South Korea, Hungary, and the Netherlands (Table 26). The historical capacity factors for U.S. reactors were lower than the worldwide average until 1988 . Since then, they have been slightly above the world average.

Figure 18. U.S. Nuclear Capacity Factors by Reactor Size, 1991-1993

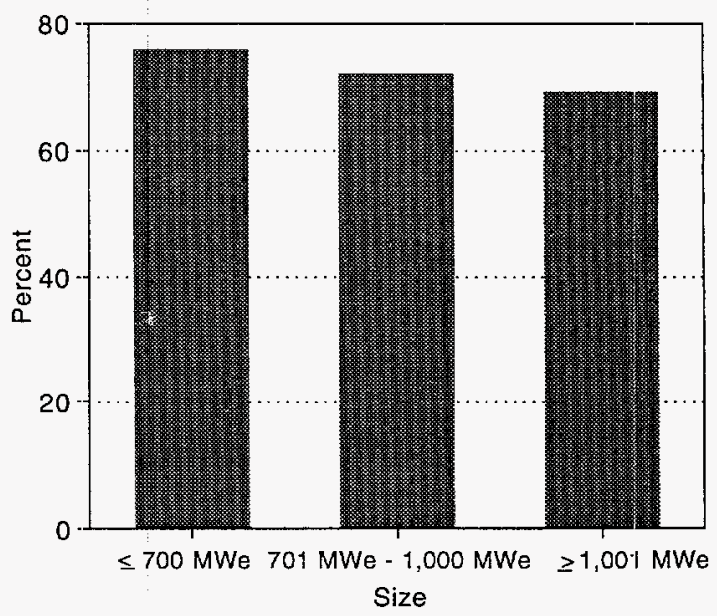

Note: $\mathrm{MWe}=$ megawatt-electric.

Source: Federal Energy Regulatory Commission, Form 1 (data obtained from the Utility Data Institute). 
Table 26. Historical Capacity Factors for World Nuclear Power Plants, 1980 to 1993 (Percent)

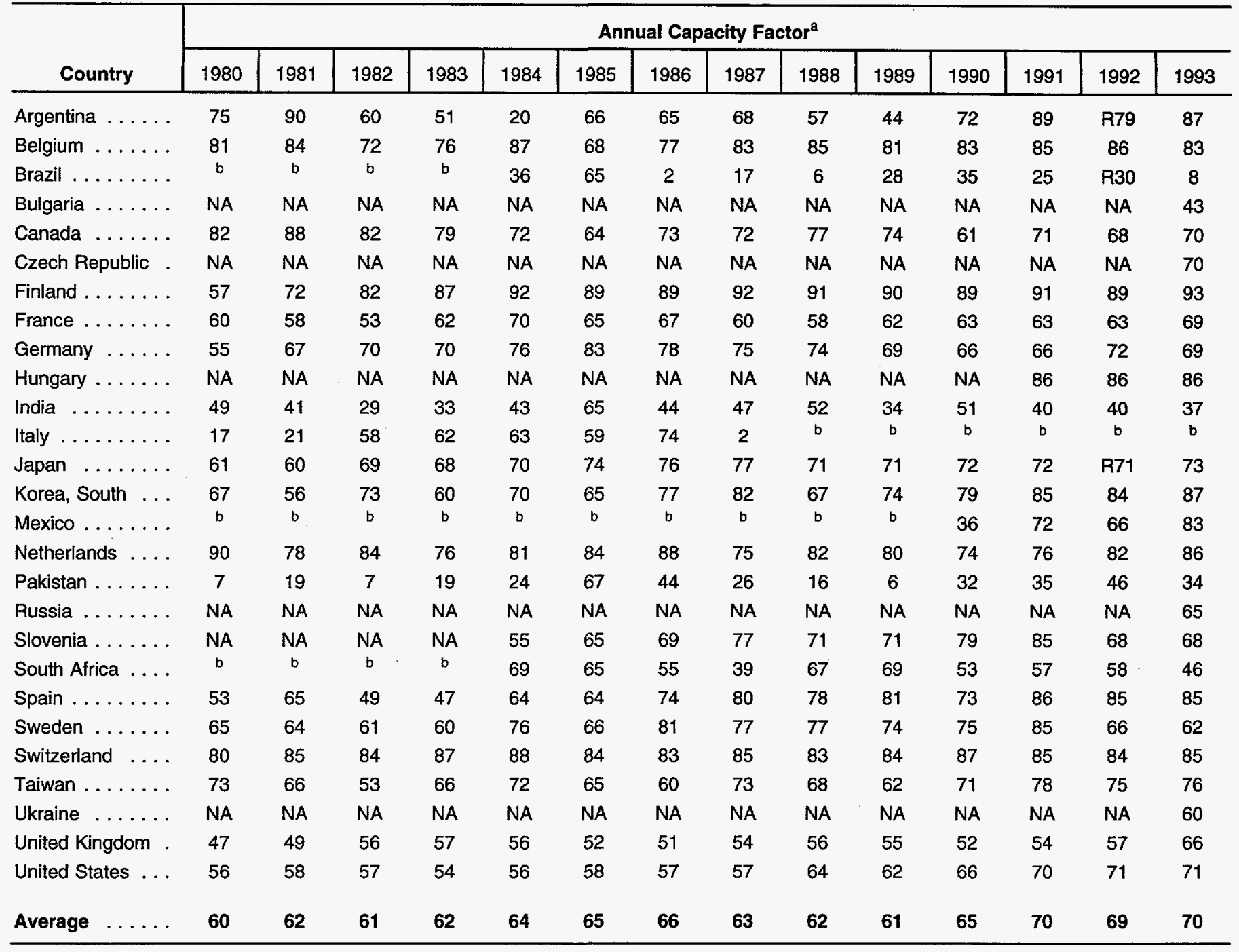

${ }^{a}$ Annual capacity factors of individual countries are based on gross generation. Historical capacity factors for Eastern Europe, China, and Former Soviet Union are not available.

${ }^{\mathrm{b}}$ No operable commercial nuclear capacity.

$R=$ revised.

NA $=$ not available

Note: The capacity factors do not include electricity generated during precommercial operation.

Sources: 1980-1993: United States: Energy Information Administration, Monthly Energy Review, DOE/EIA-0035 (94/04). 1980-1991: Foreign: Various issues of Nucleonics Week (New York: McGraw-Hill) 1992-1993: Foreign: Nucleonics Week (New York: McGraw-Hill) (February 10, 1994). 



\section{Comparison With Other Projections}

This chapter presents comparisons of projections from different organizations for nuclear capacity, uranium requirements, enrichment service requirements, and spent fuel discharges in the United States and foreign countries. A brief comparison of EIA's projections with historical values is also presented. The projections were made by the following organizations:

\section{Energy Information Administration (EIA) Energy Resources International (ERI) Nuclear Assurance Corporation (NAC) Uranium Institute (UI)}

The EIA's nuclear capacity projections are given for 1995, 2000, and 2005, and the projections of fuel cycle requirements are presented for 1994 through 2005. Appendix E contains annual projections of capacity and fuel cycle requirements through 2040 for the United States.

Three scenarios were defined by the EIA for projecting U.S. nuclear capacity and fuel cycle requirements: Low, Mid, and High. In the EIA's 1993 report, ${ }^{113}$ the corresponding cases were called No New Orders, Lower Reference, and Upper Reference. For the current Low. Case (which corresponds to the No New Orders case in the 1993 report), the reactor capacity projections depend solely on the assumption of no new orders for nuclear reactors, and the reactor retirement dates are determined by the expiration dates of the full-power licenses granted by the U.S. Nuclear Regulatory Commission (NRC). In addition, the Low Case has four units-Watts Bar 1 and 2 and Bellefonte 1 and 2-beginning operation between 1994 and 2002. This case is identical to the nuclear capacity case in the Annual Energy Outlook 1994 through 2010 except for updates of reactor capacities. ${ }^{114}$

Bellefonte 1 is projected to become operable in 1999 in the Low Case and 1998 in the Mid Case. Except for that difference, the Mid Case is the same as the Low Case through 2005. After 2005, the Mid case represents a variation in the retirement dates and startup dates for existing reactors. This scenario assumes that 55 of the 109 currently operable U.S. reactors will be lifeextended for an additional 20 years beyond their current operating license expiration dates. The reactors were selected by analyzing results from the Nuclear Plant Life-Extension (NUPLEX) model, which ranks U.S. nuclear reactors according to their likelihood for life-extension. Factors affecting life-extension decisions include economics, reactor performance, public acceptance, environmental considerations, and utility planning.

The High Case is the only growth case and it is identical to the Mid Case through 2010. After 2010, nuclear capacity growth is determined by model projections. In this chapter, EIA's High Case is compared with the projections of other organizations.

\section{Comparison of Actual versus EIA Forecasts}

Projections of nuclear electricity generation, U.S. spent fuel discharges, and worldwide nuclear capacity are less than 4 percent different from the actual values for the years shown in Table 27. The best projections for electricity generation, capacity, and spent fuel discharges were made in the 1992 report where the 1992 projection of cumulative spent fuel discharges was 25.9 thousand MTU, exactly matching the actual value for 1992. Also in the 1992 report. the projection for 1993 was 28.1 thousand MTU, less than 1 percent greater than the actual value.

The 1993 projection for worldwide nuclear capacity is 4 percent less than the actual value, 338 net GWe. The 1993 projections for cumulative spent fuel and U.S. electricity generation are 1 and less than 1 percent different from the actual values, respectively.

\footnotetext{
${ }^{113}$ Energy Information Administration, World Nuclear Capacity and Fuel Cycle Requirements 1993, DOE/EIA-0436(93) (Washington, DC, November 1993).

${ }^{114}$ Energy Information Administration, Annual Energy Outlook 1994 with Projections to 2010, DOE/EIA-0383(94) (Washington, DC, January 1994), p. 66.
} 


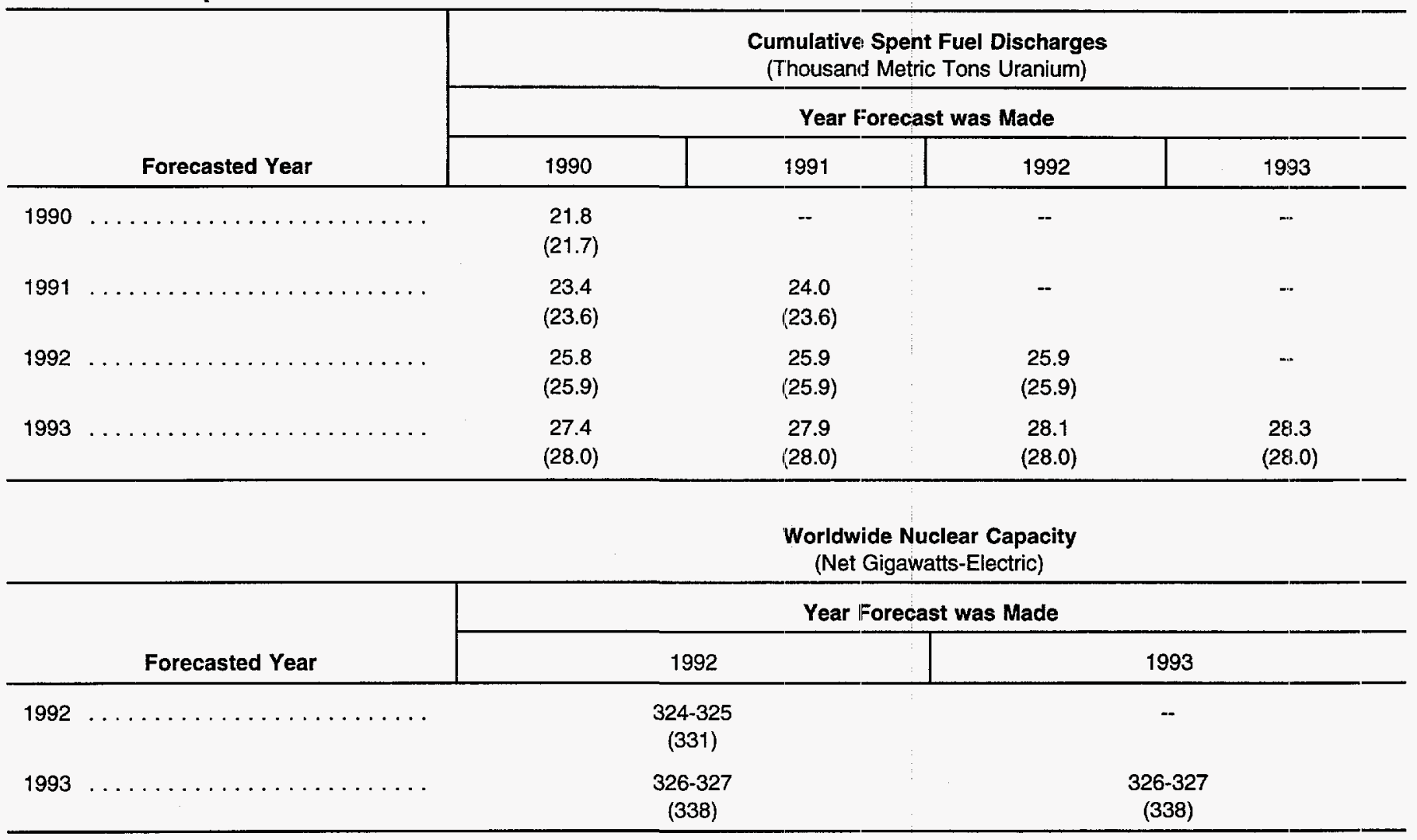

U.S. Nuclear Electricity Generation

(Net Terawatthours)

\begin{tabular}{|c|c|c|}
\hline Forecasted Year & 1992 & 1993 \\
\hline 1993 & $\begin{array}{c}612 \\
(610)\end{array}$ & $\begin{array}{c}605 \\
(610)\end{array}$ \\
\hline
\end{tabular}

Note: Actual number is shown in parenthesis.

Sources: No New Orders Case: Energy Information Administration, World Nuclear Fuel Cycle Requirements 1990, DOE/EIA-0436(90) (Washington, DC, October 1990), p. 58; World Nuclear Fuel Cycle Requirements 1991', DOE/EIA-0436(91) (Washington, DC, October 19911), p. 61; World Nuclear Fuel Cycle Requirements 1992, DOE/EIA-0436(92) (Washington, DC, December 1992), p. 110; World Nuclear Fuel Cycle Requirements 1993, DOE/EIA-0436(93) (Washington, DC, November 1993), p. 143; Spent Nuclear Fuel Discharges from U.Si. Reactors 1992, SR/CNEAF/94-01 (Washington, DC, May 1994), p. 20;

\section{Comparison with Last Year's EIA Report}

\section{Domestic Projections}

In the Low Case, the capacity projection for the United States for 1995 is 100 net gigawatts, which is the same as in the 1993 report (Table 28). For 2000 and 2005, the capacity projections (103 and 104 net gigawatts) are 2 gigawatts higher than last year's values. The higher values in 2000 and 2005 result from changes in the projected startup dates for Bellefonte 1 (1999 in the current Low Case, compared with 2001 in last year's No New Orders Case) and Bellefonte 2 (2002 in this year's Low Case, not included last year).

The midclle cases for the two reports (the $1994 \mathrm{Mid}$ Case and the 1993 Lower Reference Case), both project 
Table 28. Comparison of Projections for U.S. Nuclear Capacity at Year End, 1995, 2000, and 2005



\footnotetext{
${ }^{a}$ Capacity values are based on net summer capability ratings. GWe $=$ gigawatts-electric.

bEnergy Information Administration, World Nuclear Outlook 1994, DOE/EIA-0436 (94) (Washington, DC, November 1994). 1994 High Case projections.

'Energy Information Administration, World Nuclear Capacity and Fuel Cycle Requirements 1993, DOE/ElA-0436(93) (Washington, DC, November 1993). Upper Reference case projections.

dEnergy Resources International, Inc., 1994 Nuclear Fuel Cycle Supply and Price Report (midrange) (Washington, DC, May 1994), p. 3-18.

'Uranium Institute, Uranium in the New World Market: A Statistical Update of Supply and Demand 1991-2010 (London, England, October 1992), p. 38.

'Nuclear Assurance Corporation, Nuclear Megawatt Generation Status Report (Norcross, Georgia, February 1994), p. C-43.
}

domestic capacity for 1995 at 100 net gigawatts. For 2000 , this year's capacity projection is 2 gigawatts higher than last year's (103 vs. 101 net gigawatts), because Bellefonte 1 is projected to come on line in 1998 instead of 2001. In the 1994 Mid Case, domestic capacity increases to 104 net gigawatts in 2005, with the addition of Bellefonte 2. In the 1993 Lower Reference Case, the corresponding increase was about 3 gigawatts (from 101 net gigawatts in 2000 to 104 in 2005), with the additional capacity coming from Bellefonte 1, WNP 1, and a potentially new (i.e. generic) reactor.

Looking at the highest scenarios from the two reports (High Case and Upper Reference Case), the domestic capacity projections for 1995 and 2000 are the same- -100 and 103 net gigawatts, respectively. However, this year's High Case projection of 104 net gigawatts in 2005 is 2 gigawatts lower than last year's projection which included WNP 1 and a generic reactor.

This year's projection of total domestic uranium requirements for 1994 through 2005 is 547.4 million pounds (Table 29), slightly higher than last year's projection of 541.0 million pounds over the same period. Similarly, the projection for domestic total enrichment service requirements is 119.7 million separative work units (SWU) for 1994 through 2005, and the corresponding projection last year was 119.1 million SWU. By 2005, total spent fuel discharges are projected at 24.0 thousand metric tons of initial heavy metal (MTIHM), almost the same as the 1993 projection. The 1994 domestic projections of uranium requirements and SWU are higher than those in 1993 because the reactors' capacity factors are higher in these projections. See Chapter 4 for a brief discussion on U.S. capacity factors.

\section{Foreign Projections}

The ELA's projection of foreign nuclear capacity for 1995 is 248 net gigawatts, increasing to 281 net gigawatts by 2005 (Table 30). The 2005 projection is 1 percent below last year's projection of 284 net gigawatts.

For the period 1994 through 2005, the EIA projects that total uranium requirements for foreign countries will be 1,306.8 million pounds (Table 31), slightly more than last year's projection. Projected total enrichment service requirements for foreign countries are 272.1 million SWU, slightly less than last year's projection. Total spent fuel discharges from foreign reactors for 1994 through 2005 are projected to be 99.0 thousand MTIHM. Last year's projection was 2 percent lower, at 96.9 thousand MTIHM. The slight differences are due to adjustments to foreign fuel diets and to updating reactor capacity factors. 
Table 29. Comparison of Selected Forecasts of Fuel Cycle Requirements for the United States, 1994 Through 2005

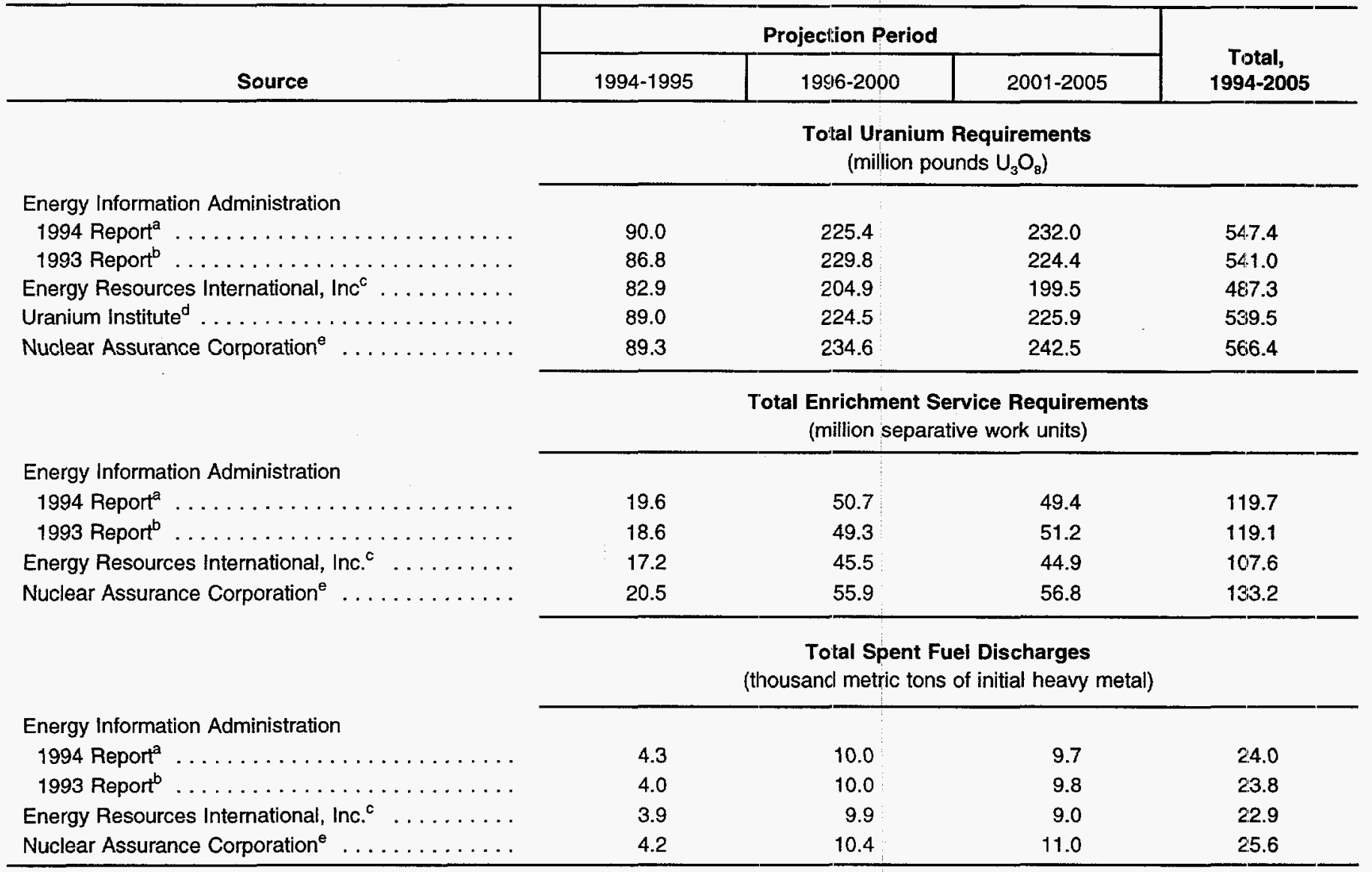

aEnergy Information Administration, World Nuclear Outlook 1994, DOE/EIA-0436(94) (Washington, DC, November 1994). 1994 High Calse projections.

${ }^{b}$ Energy Information Administration, World Nuclear Capacity and Fuel Cycle Requirements 1993, DOE/EIA-0436(93) (Washington, [IC, November 1993). Upper Reference Case projections.

${ }^{\circ}$ Energy Resources International, Inc., 1994 Nuclear Fuel Cycle Supply and Price Report (midrange) (Washington, DC, May 1994), p. 4-40.

'Uranium Institute, Uranium in the New World Market: A Statistical Update of Supply and Demand 1991-2010 (London, England, October 1992), p. 39.

Nuclear Assurance Corporation, $\mathrm{U}_{3} \mathrm{O}_{8}$ Status Report, Enrichment Status Report, and Discharge Fuel/Reprocessing Status Report (Norcross, Georgia, February 1994), pp. F-1, F-48; F-1, F-41; D-1, D-40.

\section{Comparison with Other Reports}

The projections in this report are comparable to projections found in other publications. The differences in projections made by EIA and other organizations are primarily due to dissimilar assumptions. Essentially, nuclear capacity forecasts made by other organizations are based on their judgment concerning the expected completion of nuclear units in the construction pipeline and on their perception of future electricity demand.

The techniques EIA uses to project uranium requirements and enrichment service requirements are similar to those used by the other organizations referenced in this report. Uranium and enrichment service requirements are a function of five major, interrelated variables concerning the fuel management and operating characteristics of the reactor. In computing the uranium and enrichment service requirements, values for these five must be estimated. The variables are capacity factor ( $a$ measure of capacity utilization), uranium enrichment product assay, tails assay used while enriching the uranium, the fuel burnup (i.e., the amount of energy generated from the fuel), and the length of the fuel cycle (i.e., the length of time the reactor operates before refueling). In order to obtain these values, EIA performs statistical analyses of historical reactor operating data. 
Table 30. Comparison of Projections of Foreign Nuclear Capacity at Year End, 1995, 2000, and 2005

\begin{tabular}{|c|c|c|c|}
\hline \multirow[b]{2}{*}{ Source } & \multicolumn{3}{|c|}{ Capacity (Net GWe) } \\
\hline & 1995 & 2000 & 2005 \\
\hline EIA $A^{a}-1994$ Report & 248 & 271 & 281 \\
\hline$E \mid A^{b}-1993$ Report $\ldots \ldots \ldots \ldots \ldots \ldots$ & 241 & 259 & 284 \\
\hline$\left.E R\right|^{c} \ldots \ldots \ldots \ldots \ldots$ & 244 & 265 & 282 \\
\hline Uranium Institute ${ }^{d}$. & 243 & 265 & 283 \\
\hline Nuclear Assurance Corporation ${ }^{\mathbf{e}} \ldots \ldots \ldots \ldots \ldots$ & 247 & 276 & 286 \\
\hline
\end{tabular}

${ }^{a}$ Energy Information Administration, World Nuclear Outlook 1994, DOE/EIA-0436(94) (Washington, DC, November 1994). 1994 High Case projections.

benergy Information Administration, World Nuclear Capacity and Fuel Cycle Requirements 1993, DOE/EIA-0436(93) (Washington, DC, November 1993). Upper Reference Case projections.

'Energy Resources International, Inc., 1994 Nuclear Fuel Cycle Supply and Price Report (midrange) (Washington, DC, May 1994), p. 3-33.

duranium Institute, Uranium in the New World Market: A Statistical Update of Supply and Demand 1991-2010 (London, England, October 1992), p. 33.

eNuclear Assurance Corporation, Nuclear Megawatt Generation Status Report (Norcross, Georgia, February 1994), p. C-1.

$\mathrm{GWe}=$ gigawatts-electric.

Table 31. Comparison of Selected Forecasts of Fuel Cycle Requirements for Foreign Countries, 1994 Through 2005

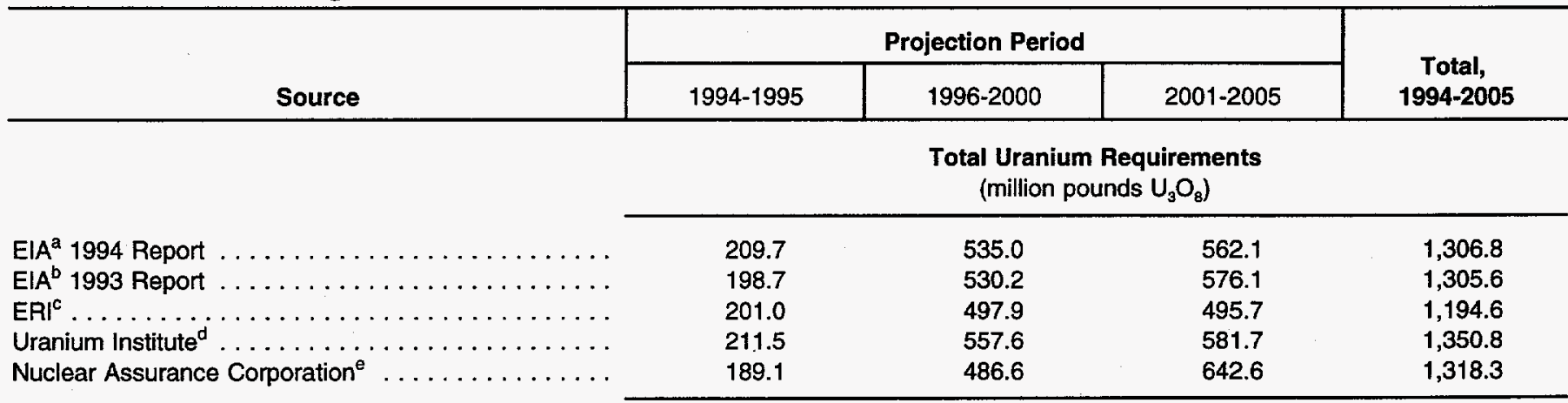

Total Enrichment Service Requirements (million separative work units)

EIA 1994 Report $\ldots \ldots \ldots \ldots \ldots \ldots \ldots \ldots \ldots$

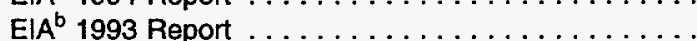

$E R I^{c} \ldots \ldots \ldots \ldots \ldots \ldots \ldots \ldots \ldots$

Nuclear Assurance Corporation ${ }^{\mathrm{e}} \ldots \ldots \ldots \ldots \ldots \ldots$

\begin{tabular}{rrrr}
\hline 42.4 & 109.2 & 120.4 & 272.1 \\
42.8 & 106.2 & 124.4 & 273.4 \\
39.9 & 101.3 & 104.5 & 245.7 \\
46.1 & 123.9 & 143.2 & 313.1 \\
\hline \multicolumn{4}{c}{ Total Spent Fuel Discharges } \\
& (thousand metric tons of initial heavy metal) \\
\hline 15.4 & 41.5 & 42.1 & 99.0 \\
16.0 & 40.0 & 40.9 & 96.9 \\
16.3 & 45.2 & 45.7 & 107.3 \\
\hline
\end{tabular}

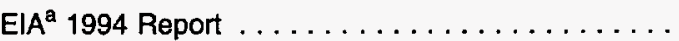

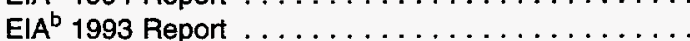

16.3

40.0

45.7

Nuclear Assurance Corporation ${ }^{e} \ldots \ldots \ldots \ldots \ldots$

${ }^{a}$ Energy Information Administration, World Nuclear Outlook 1994, DOE/ElA-0436(94) (Washington, DC, November 1994). 1994 High Case projections.

'Energy Information Administration, World Nuclear Capacity and Fuel Cycle Requirements 1993, DOE/EIA-0436(93) (Washington, DC, November 1993). Upper Reference Case projections.

'Energy Resources International, Inc., 1994 Nuclear Fuel Cycle Supply and Price Report (midrange) (Washington, DC, May 1994), p. 4-40.

dUranium Institute, Uranium in the New World Market: A Statistical Update of Supply and Demand 1991-2010 (London, England, October 1992), p. 39.

${ }^{e}$ Nuclear Assurance Corporation, $\mathrm{U}_{3} \mathrm{O}_{8}$ Status Report; Enrichment Status Report, and Discharge Fuel/Reprocessing Status Report (Norcross, Georgia, February 1994), pp. F-1, F-48; F-1, F-41; D-1, D-40. 


\section{Comparison to Energy Resources International}

Energy Resources International considers its mid case as the most likely domestic scenario, and projects that "it is not likely that there will be a new operating plant before $2005^{115}$. . ." Therefore, ERI's domestic nuclear capacity projection for 1995 is 99 net gigawatts (GWe), and its projection of domestic nuclear capacity for 2000 and 2005 is 101 net GWe. EIA projects that 4.7 net GWe come on line before 2005. Consequently, ERI's projection by 2005 is 2 percent less than EIA's. For 2005, EIA's and ERI's projections of foreign capacity are almost identical at 281 and 282 net GWe, respectively.

ERI is projecting domestic uranium requirements to be 487.3 million pounds $\mathrm{U}_{3} \mathrm{O}_{8}$ for 1994 through 2005, 11 percent less than EIA's projection. Its projection of foreign uranium requirements for 1994 through 2005 is 1,194.6 million pounds, 9 percent less than EIA's.

As ERI's nuclear power forecasts suggest, there is limited growth in domestic enrichment service requirements. ERI projects that the domestic enrichment service requirements for 1994 through 2005 will be 107.6 million SWU. EIA's projection of 119.7 million SWU is about 10 percent higher. Looking at foreign enrichment service requirements, ERI's projection of 245.7 million SWU for 1994 through 2005 is 10 percent less than EIA's.

ERI is projecting domestic spent fuel discharges to be 22.9 thousand MTIHM for 1994 through 2005; this is 5 percent less than EIA's projection. There is no projection for foreign spent fuel discharges. The fact that most of ERI's projected fuel cycle requirements are lower than EIA's is not surprising since its capacity projections are also lower.

\section{Comparison to Uranium Institute}

The projections published by the Uranium Institute in its report issued October 1992 were used here because a later report is not yet available. In that report, the UI stated that it was unlikely that Bellefonte 1 and 2 or Watts Bar 2 would be completed; consequently, it projected U.S. nuclear capacity to remain at 101 net gigawatts for 1995, 2000, and 2005. Because the three reactors were excluded from UI's capacity projection, the EIA's projection for 2005 is 3 percent higher than UI's.

As for foreign nuclear capacity, the UI shows a 16percent increase from 1995 to 2005. The EIA's increase for this time period amounts to 13 percent. Capacity projections are somewhat subjective. The dissimilarities are attributable to different estimates of startup and retirement dates for some reactors. The EIA relies on the World Integrated Nuclear Evaluation System (WINES) model for the projection of capacity in 2010, and the startup and retirement dates are obtained from the International Atomic Energy Agency publication Nuclear Power Reactors in the World. ${ }^{116}$

The UI projects that 539.5 million pounds of $\mathrm{U}_{3} \mathrm{O}_{8}$ will be needed in the United States for 1994 through 2005. This is 1 percent lower than EIA's projection. The UI also projects foreign uranium requirements for 1994 through 2.005 to be $1,350.8$ million pounds $\mathrm{U}_{3} \mathrm{O}_{3}, 3$ percent greater than EIA's projection for that time period. However, the UI did not project enrichment service requirements or spent fuel discharges.

\section{Comparison to Nuclear Assurrance Corporation}

The Nuclear Assurance Corporation states that its nuclear reactor data base contains detailed utility operating and fuel management plans that enable the company to closely reproduce individual utility requirements. The EIA collects and stores fuel management plans by country groupings rather than at the utility level. This contributes to the differences in projected fuel cycle requirements.

NAC projects domestic nuclear capacity to be 100 net GWe in 1995 and 104 net GWe in 2005. This corresponds to a 3.5-GWe increase, identical to ElA's projection for the same time period. For 1995, NAC also projects the foreign nuclear capacity to be 247 net gigawatts; NAC's 2005 projection of 286 net gigawatts implies a 1.5-percent annual growth rate. The EJA's annual growth rate for 1995 through 2005 is 1.3 percent.

Although EIA's and NAC's domestic nuclear capacity projections are similar, NAC projects higher domestic uranium requirements, enrichment service requirements, and spent fuel discharges. Requirements of 566.4

\footnotetext{
${ }^{115}$ Energy Resources International, 1994 Nuclear Fuel Cycle Supply and Price Report (Washington, DC, May 1994$)$, p. 3-11.

${ }^{116}$ International Atomic Energy Agency, Nuclear Power Reactors in the World (Vienna, Austria, Draft June 1994).
} 
million pounds of $\mathrm{U}_{3} \mathrm{O}_{8}$ are projected for domestic reactors from 1994 through 2005, 4 percent more than EIA's projection. NAC projects that domestic enrichment service requirements will be 133.2 million SWU, 11 percent more than EIA. Its projection for domestic spent fuel discharges for 1994 through 2005 is 25.6 thousand MTIHM whereas EIA's projection is 24.0 thousand MTIHM.

NAC's projection for 1994 through 2005 of foreign uranium requirements is $1,318.7$ million pounds $\mathrm{U}_{3} \mathrm{O}_{8}$. EIA's projection is slightly less. NAC's projection of foreign enrichment service requirements is 15 percent greater than EIA's, and its projection of spent fuel discharge is 107.3 thousand MTIHM, 7 percent greater than EIA's projection.

\section{Summary}

As mentioned earlier, the organizations cited here use different methods and make slightly different assumptions in arriving at their projections. Even so, EIA's projections are generally comparable. In fact, EIA's greatest differences are with NAC in projecting enrichment service requirements. The differences are 11.3 percent in the domestic projections and 15.1 percent in the foreign projections. 



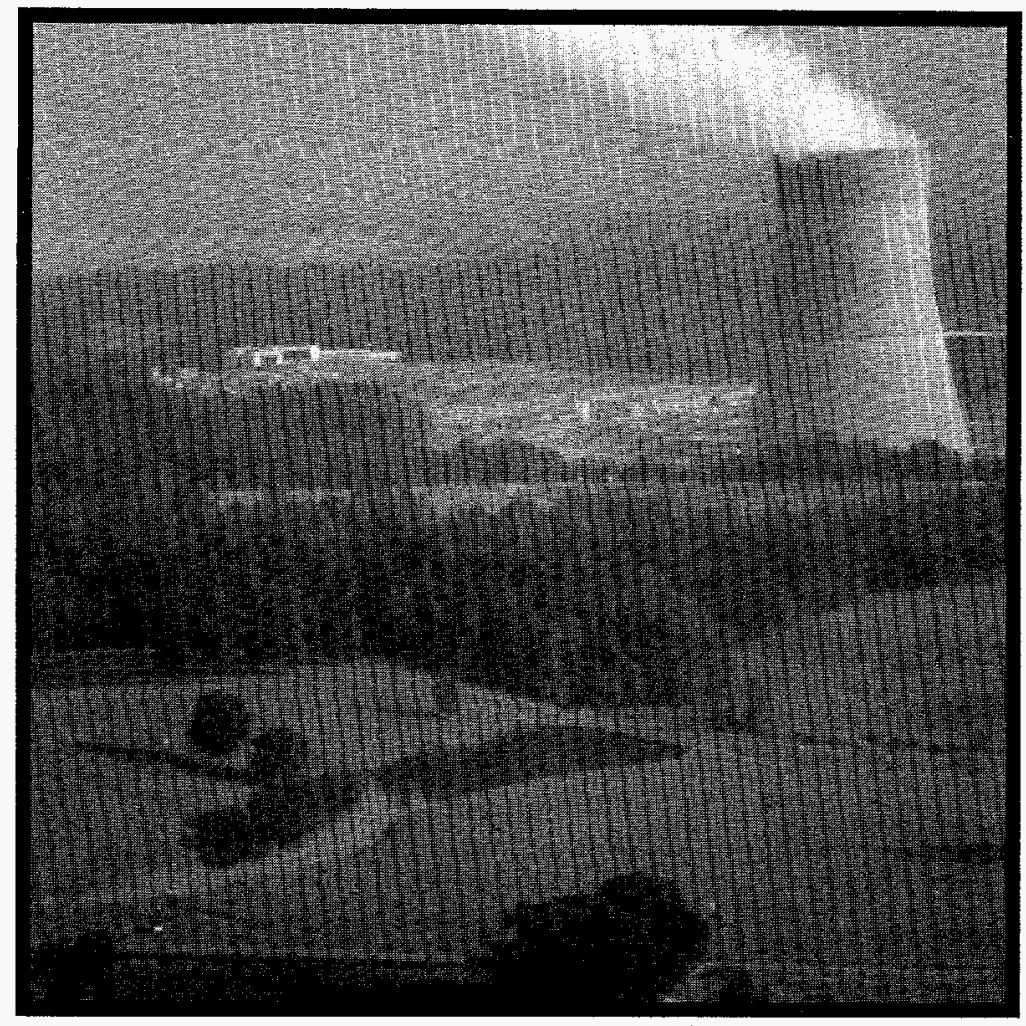

Appendix A

\section{Nuclear Power Technology and the Nuclear Fuel Cycle}

Grand Gulf, located near Port Gibson, Mississippi, has a capacity of 1,143 net $M W e$.

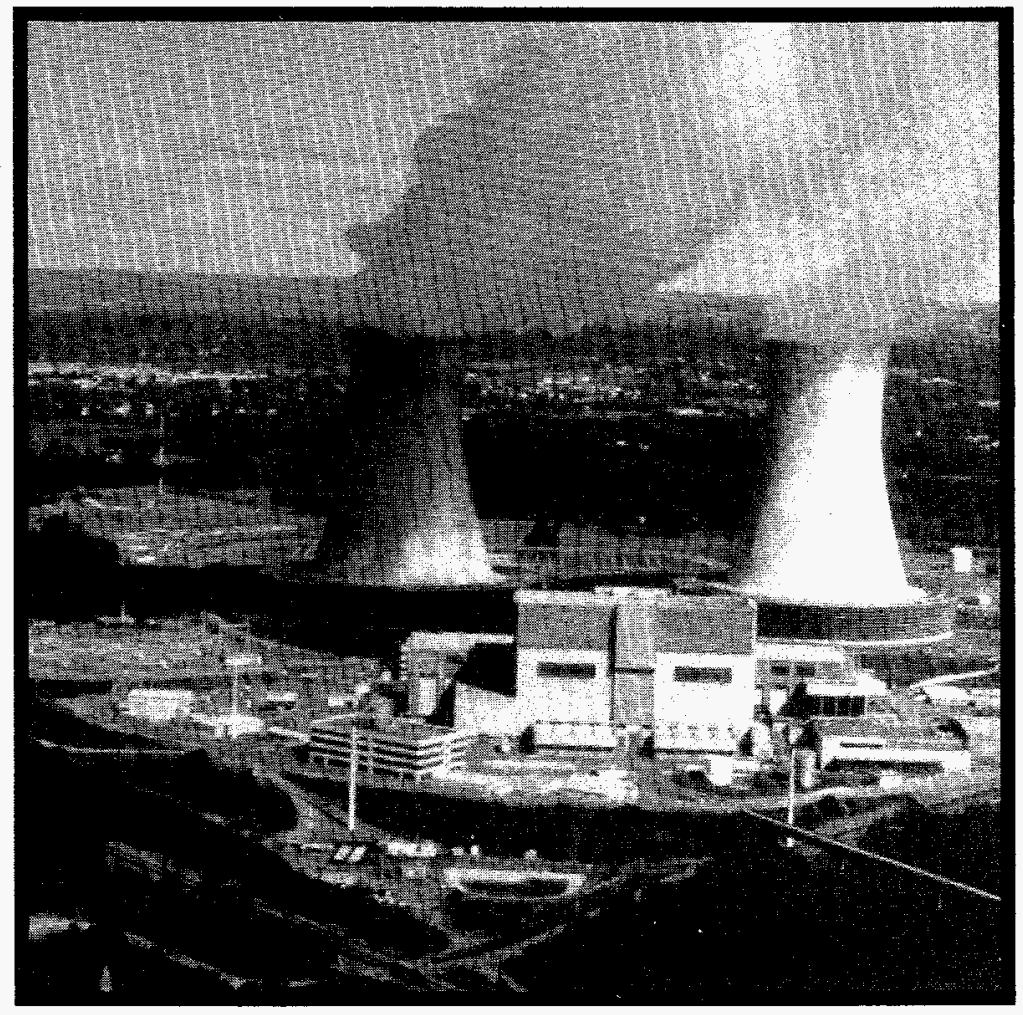

Philadelphia Electric Company's Limerick nuclear power station has a total capacity of 2,110 net MWe. 



\section{Appendix A}

\section{Nuclear Power Technology and the Nuclear Fuel Cycle}

\section{Nuclear Fission}

When the feasibility of the nuclear fission reaction was confirmed in 1939, scientists recognized that tremendous amounts of energy could be released by this process. Although early attempts to harness this energy were directed to military purposes, the harnessing of nuclear fission to produce electricity eventually became a commercial technology.

The nuclear fission process is one in which a heavy atomic nucleus (such as uranium) reacts with a free neutron. ${ }^{117}$ Most of the time this "reaction" is one in which the uranium nucleus splits (or "fissions") into two smaller nuclei, concurrently releasing energy and two or three additional free neutrons. Because more neutrons are released from a fission event than are needed to induce the event, a "chain reaction" can be sustained.

Of course, to be useful for commercial purposes, the rate of the chain reaction must be controlled. This is not as difficult as it might seem because nearly every other nucleus besides uranium reacts with free neutrons, usually by absorbing the neutron rather than by fissioning. Thus, a fission chain reaction is controlled by diluting the fissionable uranium atoms with other nonfissionable atoms.

Uranium in nature consists primarily of two "isotopes"-atoms with the same number of protons in the nucleus but different numbers of neutrons. One isotope is designated uranium-235 (or U-235); the other is uranium-238 (U-238). The numbers refer to the atomic mass, which is the sum of the number of protons and neutrons in the nucleus.

U-235 makes up only 0.7 percent of naturally occurring uranium; U-238 makes up almost all of the other 99.3 percent. U-235 nearly always reacts with a free neutron (that is, one outside the nucleus) by fissioning; thus, U-235 is called a "fissile" isotope. On the other hand, U-238 nearly always reacts with a free neutron by absorbing it rather than by fissioning. This absorption forms the isotope U-239, which in turn undergoes radioactive decay and eventually becomes $\mathrm{Pu}-239$, an isotope of the element plutonium. Pu-239, like U-235, is a fissile isotope. U-238 is referred to as a "fertile" isotope, because it eventually produces the fissile $\mathrm{Pu}-239$ isotope.

The vast majority of the world's nuclear power plants operate by passing ordinary (that is, "light") water through a nuclear reactor in which uranium fuel, housed in an array of "fuel assemblies," undergoes a controlled chain reaction. The heat produced by nuclear fission events in the reactor core is carried away by the water, either as steam in a "boiling-water reactor" or as superheated water in a "pressurized-water reactor." In a pressurized-water reactor, a device called a "steam generator" transfers the heat from water in the primary loop (which has passed through the reactor core) to water in a secondary loop, which is turned into steam. Steam produced in either a boiling-water reactor or a pressurized-water reactor then passes to an electrical turbine-generator, which actually produces the electricity. Boiling-water reactors and pressurized-water reactors are collectively called "light-water reactors." Other reactor designs have also been developed, such as the gas-cooled reactor, advanced gas-cooled reactor, and pressurized heavy-water reactor; these are used for commercial power generation in a number of foreign countries.

Because the coolant (water) in light-water reactors absorbs free neutrons, the concentration of fissile U-235 in uranium fuel must be increased over the concentration of 0.7 percent found in natural uranium in order

\footnotetext{
${ }^{117}$ Atomic nuclei consist of combinations of two types of subatomic particles, protons and neutrons, of about equal mass. The number of electrically charged protons in a nucleus determines which element it is-that is, its chemical properties. The number of protons plus the number of electrically neutral neutrons determines the weight or "atomic mass" of the nucleus. A "free neutron" is one that has been released from an atomic nucleus.
} 
for light-water reactors to sustain a nuclear chain reaction. The process of uranium enrichment, as discussed below, is used to increase the concentration of U-235 in the nuclear fuel used in light-water reactors to about 3 percent.

Before the initial startup of a nuclear power reactor, the core is loaded with fresh nuclear fuel. This fuel can be thought of as a reservoir from which energy is extracted as long as a chain reaction can be sustained. During the operation of the reactor, the concentration of U-235 decreases as U-235 nuclei fission to produce energy. In addition, fertile U-238 nuclei are constantly being converted into fissile Pu-239 nuclei, some of which will, in turn, fission and produce energy. While these reactions are taking place, the concentration of neutron-absorbing fission products (also called "poisons") increases within the nuclear fuel assemblies. When the declining concentration of fissile nuclei and the increasing concentration of poisons reach the point at which a chain reaction can no longer be sustained (that is, when free neutrons are absorbed at a rate greater than the rate of fission events), the reactor must be shut down and refueled.

The amount of energy in the "reservoir" of nuclear fuel is frequently expressed in terms of "full-power days," which is the number of days the reactor could operate at full output before a fission chain reaction would cease to be sustained. If a reactor is not operated at full power, or if it is not operated at all times, the chronological operating period is increased correspondingly. The operating period varies inversely with the plant's "capacity factor," which is the ratio of its actual level of operation to the maximum, full-power level of operation for which it is designed.

As might be expected, the number of full-power days in a nuclear reactor's operating cycle (from one refueling to the next) is related to the amount of fissile U-235 contained in the fuel assemblies at the beginning of the cycle. The higher the percentage of U-235 at the initiation of a cycle, the greater the number of fullpower days of operation in that cycle.

At the end of an operating cycle (when the chain reaction can no longer be sustained), some of the "spent" nuclear fuel is discharged and replaced with fresh fuel. The fraction of the reactor's fuel replaced at a refueling is called its "batch fraction" - typically, onefourth for boiling-water reactors and one-third for pressurized-water reactors.

The amount of energy extracted from spent fuel is called its "burnup," expressed in terms of energy (heat) produced per initial fuel weight-such as, megawattdays thermal per metric ton of initial heavy metal.

\section{The Nuclear Fuel Cycle}

The nuclear fuel cycle for a typical light-water reactor is illustrated in Figure A1. The cycle consists of a "front end" that comprises the steps necessary to prepare nuclear fuel for reactor operation and a "back end" that comprises the steps necessary to manage the spent nuclear fuel, which is highly radioactive. It is technically possible to extract the unused uranium and plutonium from spent nuclear fuel through chemical reprocessing and to recycle the recovered uranium and plutonium as nuclear fuel. The front end of the cycle is divided into the following steps:

- Exploration. Ore bodies containing uranium are first located by drilling and other geological techniques. Known deposits of ore for which enough information is available to estimate the quantity and cost of production are called reserves. Ore deposits inferred to exist but as yet undiscovered are called potential resources.

- Mining. Uranium-bearing ore is mined by methods similar to those used for other metal ores. The uranium content of ores in the United States typically ranges from 0.05 to 0.3 percent uranium oxide $\left(\mathrm{U}_{3} \mathrm{O}_{8}\right)$. In foreign countries the uranium content of ores varies widely, from 0.035 percent in South West Africa to 2.5 percent in northern Saskatchewan, Canada. In general, foreign ores are of a higher grade than those mined in the United States. Commercially significant amounts of uranium are also obtained by methods other than conventional mining, such as solution mining, and as a byproduct of phosphate mining.

- Milling. At uranium mills, usually located near the mines, uranium-bearing ore is crushed and ground, and the uranium oxide is chemically extracted. The mill product, called uranium concentrate or "yellowcake," is then marketed and sold as pounds or short tons of $\mathrm{U}_{3} \mathrm{O}_{8}$.

- Conversion to $\mathrm{UF}_{6}$. Next, the $\mathrm{U}_{3} \mathrm{O}_{8}$ is chemically converted to uranium hexafluoride $\left(\mathrm{UF}_{6}\right)$, which is a solid at room temperature but changes to a gas at slightly higher temperatures. This is a necessary feature for the next step, enrichment. 
Figure A1. The Nuclear Fuel Cycle

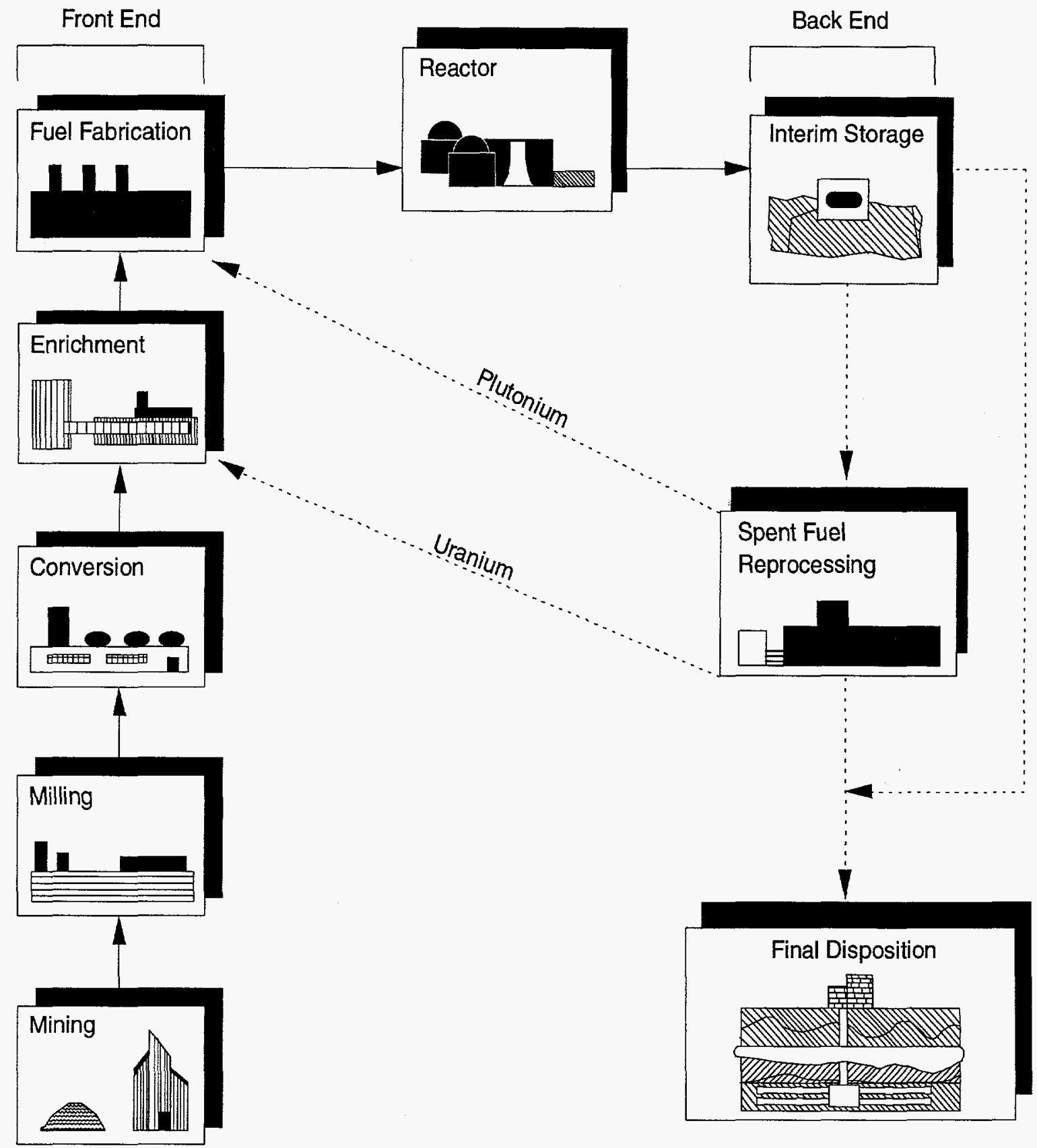

Fuel cycle as it currently operates in the United States.

Fuel cycle as it currently operates with spent reprocessing in some Foreign Countries and/or final waste storage. 
- Enrichment. Natural uranium cannot be used as fuel in light-water reactors because its content of fissile U-235 is too low to sustain a nuclear chain reaction. The gaseous diffusion process currently used for uranium enrichment (that is, increasing its U-235 content) consists of passing a "feed stream" of $\mathrm{UF}_{6}$ gas through a long series of diffusion barriers that pass U-235 at a faster rate than the heavier U-238 atoms. This differential treatment progressively increases the percentage of U-235 in the "product stream." The "waste stream" or "enrichment tails stream" contains the depleted uranium (that is, uranium having a U-235 concentration below the natural concentration of 0.7 percent). The U-235 concentration in the waste stream, called the "enrichment tails assay," is fixed by the operator of the enrichment facility. The gaseous diffusion enrichment process is extremely energy intensive. The work or energy expenditure required for uranium enrichment is measured in terms of separative work units.

A second enrichment technology, gas centrifuge separation, has been used commercially in the Netherlands. A domestic gas centrifuge separation plant was under construction but has now been canceled. A third enrichment technology, laser separation, is currently under development.

- Fabrication. The enriched $\mathrm{UF}_{6}$ is changed to an oxide and then into pellets of ceramic uranium dioxide $\left(\mathrm{UO}_{2}\right)$, which are then sealed into corrosion-resistant tubes of zirconium alloy or stainless steel. The loaded tubes, called elements or rods, are mounted into special assemblies for loading into the reactor.

The back end of the cycle is divided into the following steps:
- Interim Storage. After its operating cycle, the reactor is shut down for refueling. The fuel discharged at that time (spent fuel) is stored either at the reactor site or, potentially, in a common facility away from reactor sites. If on-site pool storage capacity is exceeded, it may be desirable to store aged fuel in modular dry storage facilities known as Independent Spent Fuel Storage Installations (ISFSI) at the reactor site or at a facility away from the site. The spent fuel rods are usually stored in water, which provides both cooling (the spent fuel continues to generate heat as a result of residual radioactive decay) and shielding (to protect the environment from residual ionizing radiation).

- Reprocessing. Spent fuel discharged from lightwater reactors contains appreciable quantities of fissile (U-235, Pu-239), fertile (U-238), and other radioactive materials. These fissile and fertile materials can be chemically separated and recovered from the spent fuel. The recovered uranium and plutonium can, if economic and institutional conditions permit, be recycled for use as nuclear fuel.

- Waste Disposal. A current concern in the nuclear power field is the safe disposal and isolation of either spent fuel from reactors or, if the reprocessing option is used, wastes from reprocessing plants. These materials must be isolated from the biosphere until the radioactivity contained in them has diminished to a safe level. Under the Nuclear Waste Policy Act of 1982, as amended, the Department of Energy has responsibility for the development of the waste disposal system for spent nuclear fuel and high-level radioactive waste. Current plans call for the ultimate disposal of the wastes in solid form in licensed deep, stable geologic structures. 


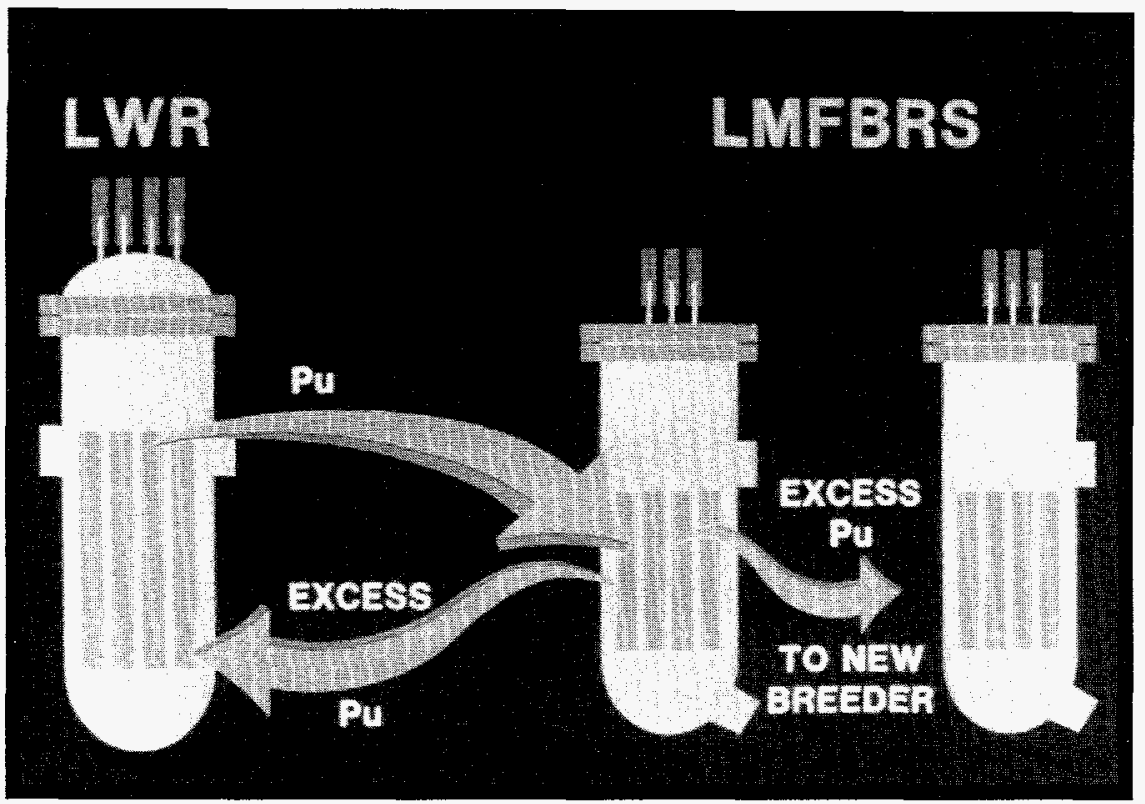

Appendix B

The Analysis Systems

Fast Breeder reactor process.

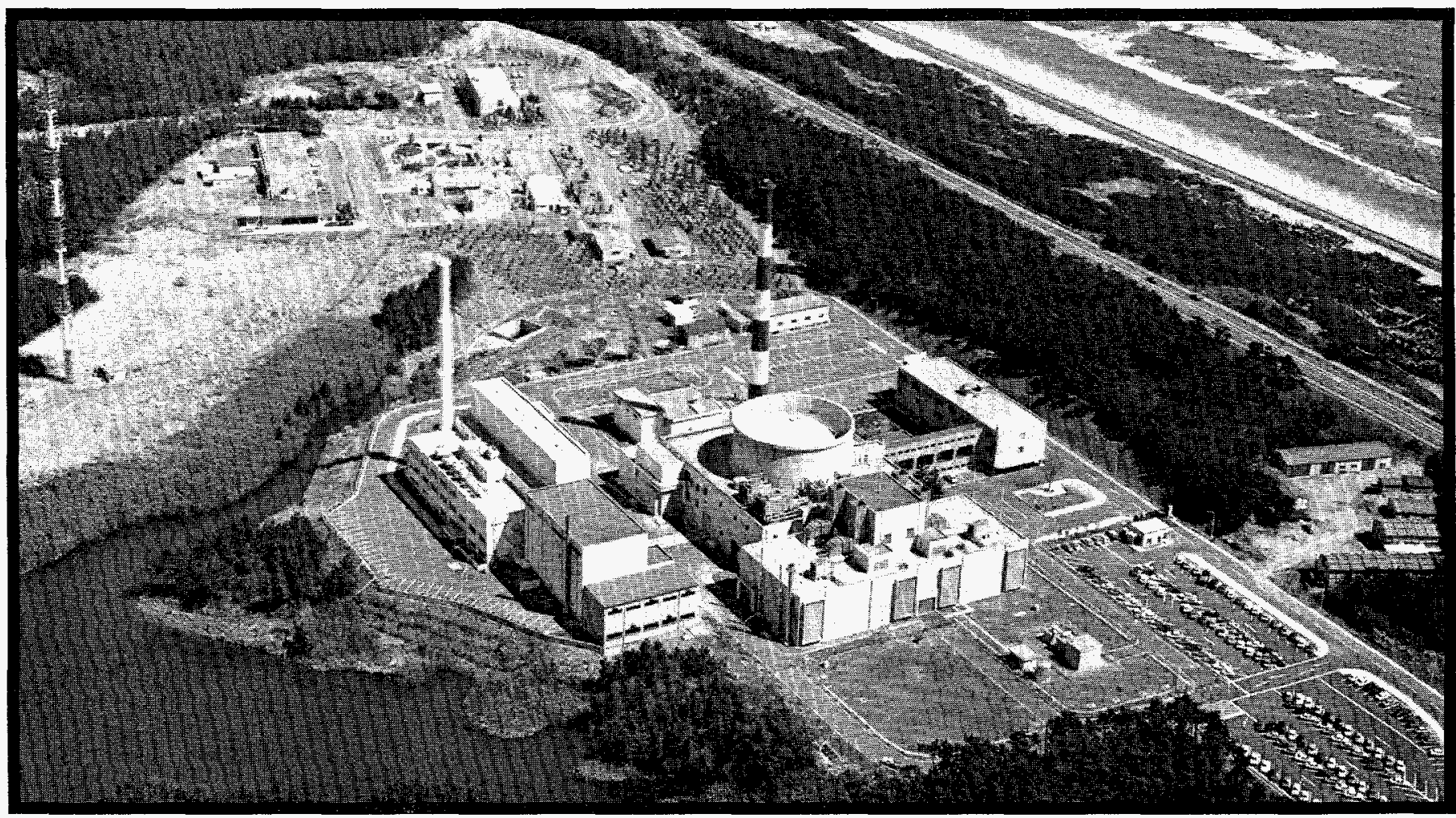

For the past 17 years, Japan has operated an experimental liquid metal cooled, loop type, fast breeder reactor. The 100MWe Joyo achieved criticality in April 1977. 


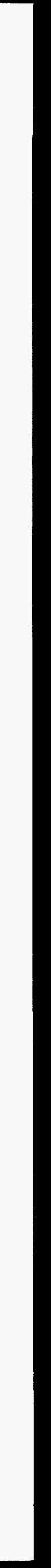




\section{Appendix B}

\section{The Analysis Systems}

\section{Economic and Energy Parameter Input Assumptions for Projecting Nuclear Capacity}

Commercial nuclear power economic and energy parameter assumptions and forecasts for the High Case were prepared by the Office of Integrated Analysis and Forecasting, Energy Information Administration, using the World Integrated Nuclear Evaluation System (WINES) model. The primary objective of the model is to produce projections of long-range world energy, electrical generation, and nuclear capacity.

Tables B1 through B3 present economic and energy parameter inputs to the model for countries that are projected to have nuclear power plants by 2010 . Within the model framework, economic (gross national product or GNP) growth is defined as the sum of growth rates for the labor-age population, the labor force participation fraction, and labor productivity. Foreign assumptions were derived from statistical studies of historical data for each country and (where available) forecasts from the Organization for Economic Cooperation and Development (OECD), International Atomic Energy Agency (IAEA), and analyst judgment. The following chiefly concentrates on the High Case parameter input values for the United States.

The labor-age population growth rate is derived from the U.S. Census Bureau middle series projections. From 1990 through 2009, population is projected to grow at an annual rate of about 0.76 percent, and from 2010 to 2030 , it is projected to decline at an annual rate of about 0.2 percent. ${ }^{118}$ For other countries, labor-age population growth rates are derived from the World Bank population projections.
Table B1. WINES Economic Parameter Values
Assumptions for the High Case
(Percent)

\begin{tabular}{|c|c|c|}
\hline Country & $\begin{array}{c}\text { Labor Force } \\
\text { Participation } \\
\text { Annual Growth } \\
\text { Rate }\end{array}$ & $\begin{array}{c}\text { Labor } \\
\text { Productivity } \\
\text { Annual Growth } \\
\text { Rate }\end{array}$ \\
\hline Canada $\ldots . . \ldots \ldots$ & 1.0 & 2.0 \\
\hline United States . . . . & 0.3 & 1.6 \\
\hline \multicolumn{3}{|l|}{ Western Europe } \\
\hline Belgium & 0.0 & 3.0 \\
\hline Finland $\ldots \ldots \ldots$ & 0.2 & 3.0 \\
\hline Germany $\ldots . \ldots \ldots$ & 0.0 & 3.0 \\
\hline Italy . . . . . . . . & 0.1 & 3.0 \\
\hline Netherlands . . . . . . & 0.3 & 3.0 \\
\hline Spain ............ & 0.1 & 3.2 \\
\hline \multicolumn{3}{|l|}{ Far East } \\
\hline Korea, South & 0.6 & 3.0 \\
\hline Taiwan .......... & 0.6 & 3.0 \\
\hline \multicolumn{3}{|l|}{ Other } \\
\hline Argentina & 0.4 & 1.0 \\
\hline India ... & 0.3 & 2.0 \\
\hline Mexico . . . . . . . . . & 0.8 & 2.0 \\
\hline Pakistan . . . . . . . . & 0.9 & 2.5 \\
\hline South Africa . . . . . . & 0.6 & 2.0 \\
\hline
\end{tabular}

Note: WINES $=$ World Integrated Nuclear Evaluation System. Values are indicated for those countries where WINES was used to develop the forecasts. In the High Case, WINES was used for all countries except Brazil, France, Japan, Slovenia, Sweden, Switzerland, and the United Kingdom.

Source: Decision Analysis Corporation of Virginia, Final Report: WINES Model Analysis (OECD Countries), DOE Contract No. DEAC01-87EI-19801 (Vienna, VA, November 15, 1991), Volumes 1-3; WINES Model Analysis (Non-OECD Countries), DOE Contract No. DEAC01-92EI-22941 (Vienna, VA, March 27, 1992); Energy Information Administration, Office of Integrated Analysis and Forecasting.

\footnotetext{
${ }^{118}$ However, 5-year growth rates are used as model inputs rather than the 20-year averages since WINES produces outputs at 5-year intervals.
} 
Table B2. WINES Energy Assumptions for the High Case (Percent)

\begin{tabular}{|c|c|c|c|}
\hline Country & $\begin{array}{l}\text { Aggregate Delivered } \\
\text { Energy Real Annual } \\
\text { Price Growth Rate }\end{array}$ & $\begin{array}{c}\text { Price } \\
\text { Elasticity of } \\
\text { Aggregate Delivered } \\
\text { Energy Demand }\end{array}$ & $\begin{array}{c}\text { Income } \\
\text { Elasticity of } \\
\text { Aggregate Delivered } \\
\text { Energy Demand } \\
\end{array}$ \\
\hline$\ldots \ldots \ldots \ldots \ldots$ & 1.0 & -0.3 & 0.6 \\
\hline United States $\ldots \ldots \ldots \ldots \ldots \ldots \ldots$ & 0.9 & -0.17 & 0.6 \\
\hline \multicolumn{4}{|l|}{ Western Europe } \\
\hline Belgium $\ldots \ldots \ldots \ldots \ldots \ldots$ & 0.5 & -0.3 & 0.6 \\
\hline Finland $\ldots \ldots \ldots \ldots \ldots \ldots$ & 0.5 & -0.3 & 0.6 \\
\hline Germany $\ldots \ldots \ldots \ldots \ldots \ldots \ldots$ & 1.0 & -0.3 & 0.6 \\
\hline$\ldots \ldots \ldots \ldots \ldots \ldots \ldots \ldots$ & 1.5 & -0.3 & 0.6 \\
\hline Netherlands $\ldots \ldots \ldots \ldots \ldots \ldots$ & 1.0 & -0.3 & 0.6 \\
\hline Spain .................... & 0.5 & -0.3 & 0.6 \\
\hline \multicolumn{4}{|l|}{ Far East } \\
\hline$\ldots \ldots \ldots \ldots \ldots \ldots$ & 1.5 & -0.3 & 0.6 \\
\hline Taiwan . . . . . . . . . . . . . & 1.5 & -0.3 & 0.6 \\
\hline \multicolumn{4}{|l|}{ Other } \\
\hline$\ldots \ldots \ldots \ldots \ldots$ & 1.5 & -0.3 & 0.6 \\
\hline$\ldots \ldots \ldots \ldots \ldots$ & 1.5 & -0.3 & 0.9 \\
\hline$\ldots \ldots \ldots \ldots \ldots$ & 1.5 & -0.3 & 0.6 \\
\hline Pakistan . . . . . . . . . . . . & 1.5 & -0.3 & 0.9 \\
\hline South Africa $\ldots \ldots \ldots \ldots \ldots \ldots$ & 1.5 & -0.3 & 0.6 \\
\hline
\end{tabular}

Note: WINES $=$ World Integrated Nuclear Evaluation System. Values are indicated for those countries where WINES was used to develop the forecasts. In the High Case, WINES was used for all countries except Brazil, France, Japan, Slovenia, Sweden, Switzerland, and the United Kingdom.

Source: Decision Analysis Corporation of Virginia, Final Report: WINES Model Analysis (OECD Countries), DOE Contract No. DE-AC01-87EI-19801 (Vienna, VA, November 15, 1991), Volumes 1-3; WINES Model Analysis (Nor:OECD Countries), DOE Contract No. DE-AC01-92El-22941 (Vienna, VA, March 27, 1992); Energy Information Administration, Office of Integrated Analysis and Forecasting.

The labor force participation fraction rate is assumed to increase at an annual rate of 0.30 percent (Table B1). The rate is slightly lower than the 0.40 -percent-per-year estimate by the U.S. Bureau of Labor Statistics (BLS) for the period 1988 through $2000 .{ }^{119}$

Labor productivity is assumed to grow at a rate of 1.6 percent per year (Table B1). The value is expected to be higher than the average annual productivity growth rate for the past 25 years of about 1.5 percent, based upon BLS productivity indices. ${ }^{120}$ Also, the BLS has developed projections of labor productivity growth rates of 1.3 to 1.4 percent per year for the period 1988 through $2000 .^{121}$
Domestic labor-age population, participation, and productivity growth rates yield an average GNP growth rate of 1.7 percent annually between 2010 and 2030.

The function describing growth in demand for delivered energy uses GNP growth rates plus assumptions regarding growth in the real price of aggregate energy and corresponding price and income elasticities of demand for energy as inputs. The real aggregate energy price is assumed to increase at an annual rate of 0.9 percent (Table B2).

\footnotetext{
${ }^{119}$ Bureau of Labor Statistics, U.S. Department of Labor, Outlook 2000, Bulletin 2352 (Washington, DC, April 1990).

${ }^{120}$ Bureau of the Census, U.S. Department of Commerce, Statistical Abstract of the United States 1990, 110th ed., Table No. 664, "Indices of Productivity and Related Measures: 1960 to 1988" (Washington, DC, January 1990), p. 406.

${ }^{121}$ Bureau of Labor Statistics, U.S. Department of Labor, Outlook 2000, Bulletin 2352 (Washington, DC, April 1990).
} 
Table B3. WINES Electrical and Nuclear Share Parameter Values Assumed for the High Case

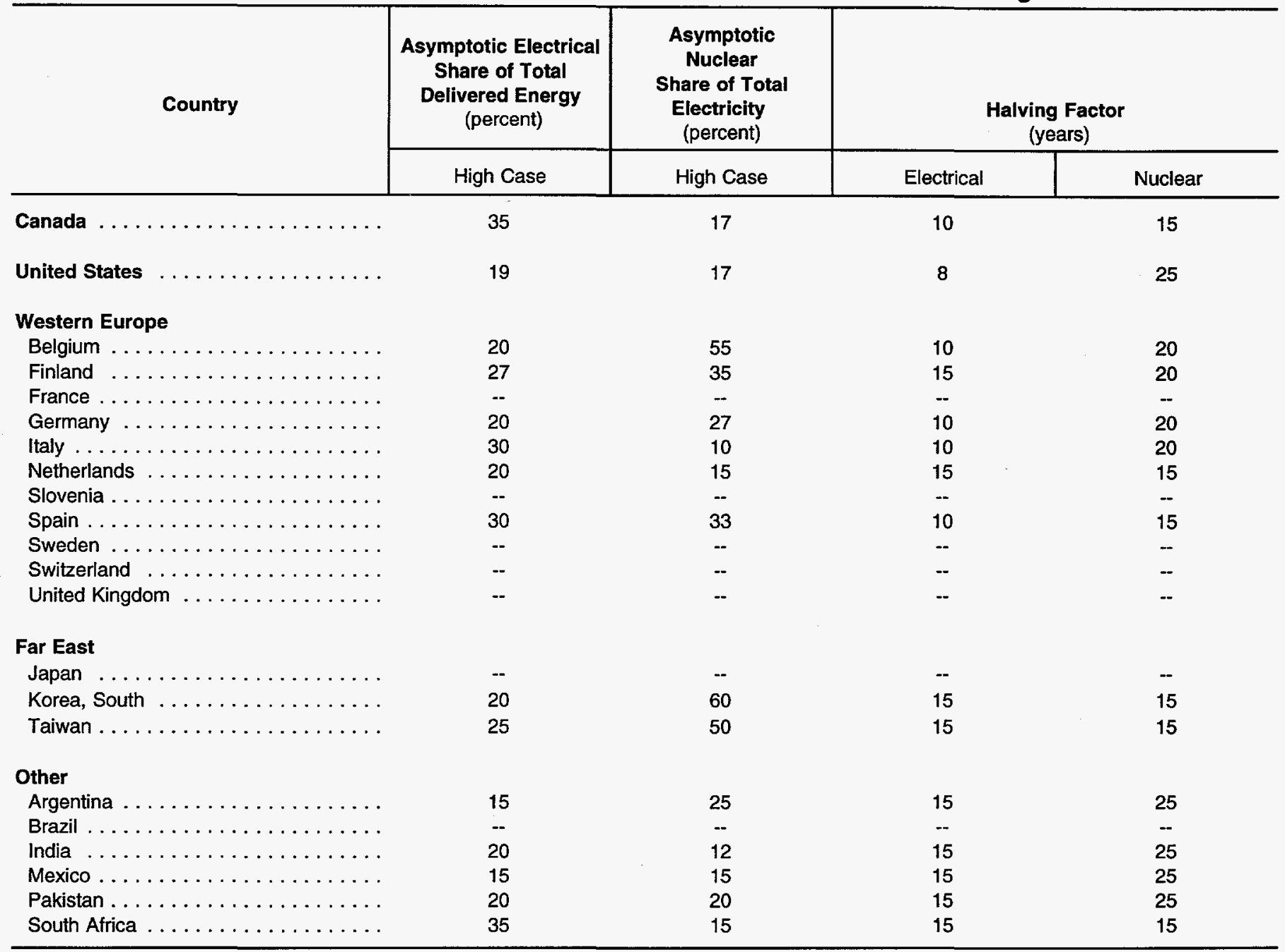

Note: WINES = World Integrated Nuclear Evaluation System. Values are indicated for those countries where WINES was used to develop the forecasts. In the High Case, WINES was used for all countries except Brazil, France, Japan, Slovenia, Sweden, Switzerland, and the United Kingdom.

Source: Decision Analysis Corporation of Virginia, Final Report: WINES Model Analysis (OECD) Countries), DOE Contract No. DE-ACO1-87EI19801 (Vienna, VA, November 15, 1991), Volumes 1-3; WINES Model Analysis (Non-OECD Countries), DOE Contract No. DE-AC01-92El-22941 (Vienna, VA, March 27, 1992); Energy Information Administration, Office of Integrated Analysis and Forecasting.

Price elasticity of aggregate energy demand is assumed to be -0.17 (Table B2). The elasticity value is consistent with the aggregate end-use energy price elasticities computed from data for the period 1970 to 1987. Energy price elasticities are generally considered to be greater (in absolute value) for developed countries than for developing countries, reflecting the premise that higher income countries have better opportunities for energy substitution than do countries with relatively lower incomes. Income elasticity of aggregate energy demand in the U.S. is assumed to be 0.6 (Table B2). The elasticity is consistent with the income elasticity of 0.6 computed with data for the period 1970 to 1987 as well as that of 0.6 in the National Energy Strategy (NES) projections through 2030 . For developing countries, the greater values for income elasticities are due to the potential for energy-intensive industrialization as income increases.

The electrical share of delivered energy and the nuclear share of electricity are derived using market penetration functions. These functions require assumptions regarding the long-run asymptotic shares and halving factors. The halving factor determines how fast the share from the base-year value approaches the asymptotic value. The base year for electrical and nuclear share for the High case is 2010. 
The asymptotic electrical share of delivered energy is assumed to be 19 percent (Table B3). The assumption is based on an analysis of the historical penetration of electricity in the United States and by fitting the best logistic curve to the historical data. The 1993 electrical share (utility and non-utility) of delivered energy was 19.1 percent. The electrical halving factor is assumed to be 8 years since there are many new end-use technologies on the horizon and the electric industry is a mature one. It is assumed, therefore, that increases in electricity can be achieved relatively quickly.

The asymptotic nuclear share of electrical generation, derived in a manner similar to that used for the asymptotic electrical share, is assumed to be 17 percent (Table B3). OECD countries were estimated by analyzing historical shares and fitting logistic market penetration functions to these historical data. The asymptotic electrical shares of delivered energy vary from 20 to 30 percent for the OECD countries, while the asymptotic nuclear shares of electrical generation range from 10 to 55 percent. For non-OECD countries, the asymptotic electrical shares of delivered energy are assumed to fall in a range from 15 to 35 percent, while the asymptotic nuclear share of electrical generation range from 12 to 60 percent. The 1993 domestic nuclear share of total utility-electrical generation was 21.2 percent. The continuing uncertainty regarding waste disposal, licensing, and safety verification procedures makes it likely that more time will be required to achieve the nuclear asymptotic share. Therefore, the nuclear halving factor is assumed to be 25 years (Table B3).

\section{Nuclear Fuel Management Plans and Nuclear Fuel Burnup}

Fuel management plans for the generic reactor categories were developed from a statistical analysis of historical fuel cycle data. The historical data include the following: capacity, fuel inserted per cycle $\left(\mathrm{U}_{3} \mathrm{O}_{8}\right.$, uranium metal, U-235), requirements for uranium enrichment service, cycle length, capacity factor, fullpower days, spent fuel discharges, and fuel burnup.

Nuclear fuel burnup is a measure of the amount of energy produced from each metric ton of enriched uranium. The average discharge burnup levels have been increasing and increases are expected to continue. For boiling-water reactors, the average equilibrium spent fuel discharge burnup in 1993 was approximately 31,500 megawattdays thermal per metric ton of initial heavy metal (MWDT/MTIHM). The burnup values ranged from less than 20,000 to 38,000 MWDT/MTIHM.
The majority of spent fuel discharges ( 83 percent) were between 26,000 and 35,000 MWDT/MTIHM. For pressurized-water reactors, the average equilibrium spent fuel discharge burnup in 1993 was about 39,000 MWDT/MTIHM. The values ranged from under 201,000 to $54,000 \mathrm{MWDT} / \mathrm{MTIHM}$, with the majority of spent fuel discharges (85 percent) between 32,000 and 45,000 MWDT/MTIHM.

Equilibrium design burnup levels for U.S. commercial nuclear fuel in the early 1980's were around 28,000 and 33,000 MWDT/MTIHM for boiling-water reactors and pressurized-water reactors, respectively. Engineering advances in fuel integrity and improved fuel management techniques were developed through a joint effort by Government and industry, resulting in higher burnups. In this report, fuel with design burnup above 28,000 MWDT/MTIHM for boiling-water reactors and 33,000 MWDT/MTIHM for pressurized-water reactors is referred to as "extended burnup fuel." The following pages of this Appendix describe the procedures used to develop fuel plans associated with extended fuel burnup levels.

A fuel plan consists of the following:

- Amount of uranium loaded

- Enrichment assay of the uranium loaded

- Planned number of full-power days

- Design burnup level of the discharged spent fuel.

In an ideal equilibrium cycle, any two of the above parameters determine the other two parameters. The equations relating the parameters are:

$$
F B=S D,
$$

and

$$
E=a+b B(1+F)
$$

where:

$$
\begin{aligned}
F= & \text { fraction of the core being replaced in an } \\
& \text { equilibrium reloading, } \\
B= & \text { equilibrium discharge batch average burnup } \\
& \text { (megawattdays thermal per metric ton of initial } \\
& \text { heavy metal), } \\
D= & \text { equilibrium full-power days (days), } \\
S= & \text { core specific power (megawatts thermal per } \\
& \text { metric ton of initial heavy metal), } \\
E= & \text { enrichment assay (percent), }
\end{aligned}
$$

and $a$ and $b$ are regression coefficients. 
The fraction of the core replaced is functionally equivalent to the amount of enriched uranium loaded. Equation (1) implies that in an equilibrium mode, the core average burnup, $S D$, equals the discharge batch average burnup, $B$, times the batch fractional average, $F$. For example, if $F=1 / 3$ and $B=33,000$ megawattdays thermal per metric ton of initial heavy metal, then the core average burnup is 11,000 megawattdays thermal per metric ton of initial heavy metal. That is, a batch of fuel stays in the core for three cycles, receiving an exposure of 11,000 megawattdays thermal per metric ton of initial heavy metal during each cycle. The core specific power, $S$, depends on the particular reactor and core configuration being considered. However, there is a high correlation between core specific power and the ratio of the reactor's rated thermal power to core size (uranium content), so that for modeling purposes, $S$ can be considered invariant for an individual reactor.

Equation (2) assumes a linear reactivity model: that is, the rate of change of reactivity with fuel burnup is constant. The parameters $a$ and $b$ are fixed values determined from the analysis of a coupled thermalhydraulic nuclear fuel cycle; $b$ depends on bundle design, and $a$ depends on leakage. Both $a$ and $b$ can be affected by design variables governing the conversion ratio and change in the slope of reactivity versus burnup. In an ideal equilibrium cycle, Equation (2) may be interpreted as relating enrichment assay to total burnup, where total burnup is defined as the sum of the discharge burnup, $B$, and the cycle equilibrium burnup, BF. In practice, the assumption of a linear relationship between enrichment assay and total burnup must be tempered because of the incorporation of burnable poisons with the nuclear fuel. Burnable poisons are used in higher burnup fuel to control reactivity and limit power peaking. The addition of burnable poisons to the nuclear fuel requires moderate increases in enrichment assays to obtain a given burnup objective. This additional U-235 requirement introduces an upward concavity in the enrichment-burnup rela- tionship. However, Equation (2) does provide a good estimate of the relationship over a reasonable burnup range.

Under the conditions described above, Equations (1) and (2) provide a reasonable approximation for an ideal equilibrium cycle. To obtain generic parameters characterizing a typical boiling-water reactor and pressurized-water reactor, estimates of the coefficients in Equation (2) are obtained using a regression analysis.

The regression parameters in Equations (3) and (4) were estimated by a regression analysis applied to fuel management projections supplied to DOE by utilities on Form RW-859. Separate estimates were made for boiling-water reactors and pressurized-water reactors. Only fuel with zircalloy cladding was considered. Prior to applying the regression analysis, anomalous data were identified and eliminated from the analysis set. The R-squared values were 0.83 and 0.76 for pressurized-water reactors and boiling-water reactors (Table B4), respectively.

The " $t$ " test was used to test the regression coefficients against the null hypothesis that they were not significantly different from zero. This test produces a statistical measure for determining whether a variable should be included in the model. In all cases, the coefficients were statistically significant at the 0.0001 level (Table B5).

Substituting the results of the regression analysis in Equation (2) yields the following expressions. For boiling-water reactors:

$$
E=1.052+0.0000457 B(1+F) .
$$

For pressurized-water reactors:

$$
E=0.846+0.0000507 B(1+F) \text {. }
$$

Table B4. Results of the Regression Analysis of the Enrichment Assay Equations

\begin{tabular}{lc|c|c|c}
\hline \multicolumn{1}{c|}{ Reactor Type } & Independent Variable & Intercept & Burnup x (1 + Core Fraction) & R-squared \\
\hline Boiling Water Reactor & Assay & 1.052 & 0.0000457 & 0.76 \\
Pressurized-Water & Assay & 0.846 & 0.0000507 & 0.83 \\
\hline
\end{tabular}

Source: Energy Information Administration, Office of Coal, Nuclear, Electric, and Alternate Fuels, Analysis and Systems Division, working papers, April 1994. 


\begin{tabular}{|c|c|c|}
\hline \multirow[b]{2}{*}{ Parameter } & \multicolumn{2}{|c|}{ Reactor Type } \\
\hline & Boiling Water Reactor & Pressurized-Water Reactor \\
\hline \multicolumn{3}{|l|}{ Intercept } \\
\hline Value from $t$ Test & 11.656 & 11.390 \\
\hline Significance Level . . . . . . & 0.0001 & 0.0001 \\
\hline \multicolumn{3}{|l|}{ Burnup $\times(1+$ Core Fraction $)$} \\
\hline Value from $t$ Test . . . . & 23.346 & 40.354 \\
\hline Significance Level $\ldots \ldots \ldots \ldots \ldots \ldots \ldots$ & 0.0001 & 0.0001 \\
\hline
\end{tabular}

Source: Energy Information Administration, Office of Coal, Nuclear, Electric, and Alternate Fuels, Analysis and Systemis Division, working papers, April 1994.

The projected discharge burnup data from Form RW-859, "Nuclear Fuel Data Survey," that was used in this analysis peaked at 55,000 megawattdays thermal per metric ton of initial heavy metal for boiling-water reactors and 64,000 megawattdays thermal per metric ton of initial heavy metal for pressurized-water reactors. Equations (3) and (4) are not applied to burnup levels exceeding these limits, because utilities are only now developing fuel management plans for burnup levels past these limits, and utility-supplied data for fuel management plans associated with these higher burnup goals are not currently available. For higher burnup ranges, the following analysis is used to establish the relationship between burnup, enrichment assay, and core replacement fraction.

Estimates of the technical parameters in Equation (2) were supplied by General Electric Corporation. Equation (2) can be written in the following difference format:

$$
\Delta E=b \Delta[B(1+F)],
$$

where $\Delta$ indicates the difference operator. This equation is applied to a given fuel management plan consisting of an assay $E_{1}$, a burnup $B$, and a core fraction $F_{1}$. If a new fuel management plan has a burnup $B_{2}$ and a core fraction $F_{2}$, then

$$
\Delta[B(1+F)]=B_{2}\left(1+F_{2}\right)-B_{1}\left(1+F_{1}\right) .
$$

The change in enrichment assay is calculated by $\Delta E=b$ $\Delta[B(1+F)]$, and the new enrichment assay is given by $E_{2}=E_{1}+\Delta E$.

General Electric Corporation suggested that an appropriate value of $b$ in the higher burnup ranges is
0.000063 . This value of $b$ provides a good approximation for both boiling-water reactors (BWR) and pressurized-water reactors (PWR). Note that the value of the parameter $a$ in Equation (2) depends on the generic reactor type. Using the General Electric Corporation value for $b$, Equation (5) becomes

$\Delta E=0.000063 \Delta[B(1+F)]$.

As Equation (1) indicates, for a given discharge burnup and a given number of effective full-power days per cycle, the core fraction depends on the specific power of the reactor. The reactor fuel management plans used in the International Nuclear Model, PC Version are based on the generic reactor types and implicitly incorporate a mean specific power value for a generic boiling-water and pressurized-water reactors, respectively.

Equation (1) is used to calculate the core fraction of a new fuel diet plan,

$$
F=(S D) / B,
$$

Utilities typically develop fuel management plans to meet effective full-power days and discharge burnup goals. That is, they specify the amount of energy to be produced during the cycle and the desired discharge burnup of the fuel, and use these objectives to determine the amount and enrichment assay of the fresh uranium loaded. The burnup objectives are generally determined by economic and operational considerations.

Domestic and foreign fuel management plans for extended burnup are developed for generic boilingwater reactors and pressurized-water reactors (Tables B6 and B7). Each plan is based on assumptions for the 


\begin{tabular}{|c|c|c|c|c|}
\hline Year Fuel Plan is Used & $\begin{array}{l}\text { Effective Full- } \\
\text { Power Days }\end{array}$ & Core Fraction & $\begin{array}{c}\text { Enrichment Assay } \\
\text { (percent) }\end{array}$ & $\begin{array}{c}\text { Design } \\
\text { Burnup } \\
(\mathrm{MWDT} / \mathrm{MTu})^{\mathrm{a}}\end{array}$ \\
\hline \multicolumn{5}{|l|}{ Boiling-Water Reactors } \\
\hline $1993 \ldots \ldots \ldots \ldots$ & 411 & 0.287 & 2.99 & 33,000 \\
\hline 1995 & 450 & 0.288 & 3.17 & 36,000 \\
\hline 2002 & 489 & 0.289 & 3.30 & 39,000 \\
\hline $2010 \ldots \ldots$ & 511 & 0.274 & 3.53 & 43,000 \\
\hline \multicolumn{5}{|l|}{ Pressurized-Water Reactor } \\
\hline 1993 & 431 & 0.380 & 3.78 & 42,000 \\
\hline $1998 \ldots \ldots \ldots \ldots \ldots \ldots \ldots \ldots \ldots$ & 460 & 0.370 & 4.04 & 46,000 \\
\hline $2004 \ldots \ldots \ldots \ldots \ldots \ldots \ldots \ldots$ & 485 & 0.359 & 4.35 & 50,000 \\
\hline $2007 \ldots \ldots \ldots \ldots$ & 511 & 0.344 & 4.73 & 55,000 \\
\hline
\end{tabular}

${ }^{a}$ MWDT/MTU = Megawattdays thermal per metric ton uranium.

Source: Energy Information Administration, Office of Coal, Nuclear, Electric, and Alternate Fuels, Analysis and Systems Division, working papers, April 1994.

Table B7. Foreign Fuel Management Plans for Extended Burnup Scenarios

\begin{tabular}{|c|c|c|c|c|}
\hline Year Fuel Plan is Used & $\begin{array}{c}\text { Effective } \\
\text { Full-Power } \\
\text { Days }\end{array}$ & $\begin{array}{c}\text { Core } \\
\text { Fraction }\end{array}$ & $\begin{array}{c}\text { Enrichment } \\
\text { Assay } \\
\text { (Percent) }\end{array}$ & $\begin{array}{c}\text { Design } \\
\text { Burnup } \\
\text { (MWDT/MTu) }^{\mathrm{a}}\end{array}$ \\
\hline \multicolumn{5}{|l|}{ Boiling-Water Reactors } \\
\hline $1993 \ldots \ldots \ldots \ldots \ldots \ldots \ldots \ldots$ & 309 & 0.206 & 3.22 & 37,664 \\
\hline $1995 \ldots \ldots \ldots \ldots \ldots \ldots \ldots \ldots \ldots$ & 309 & 0.190 & 3.29 & 40,748 \\
\hline $2004 \ldots \ldots \ldots \ldots \ldots \ldots \ldots \ldots$ & 309 & 0.165 & 3.57 & 46,916 \\
\hline 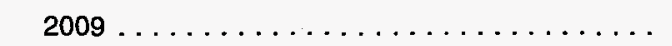 & 309 & 0.155 & 3.71 & 50,000 \\
\hline \multicolumn{5}{|l|}{ Pressurized-Water Reactor } \\
\hline $1993 \ldots \ldots \ldots \ldots \ldots \ldots \ldots \ldots \ldots$ & 288 & 0.268 & 3.61 & 40,274 \\
\hline $1994 \ldots \ldots \ldots \ldots \ldots \ldots \ldots \ldots$ & 288 & 0.246 & 3.63 & 43,956 \\
\hline \multicolumn{5}{|l|}{ Boiling-Water Reactors } \\
\hline $1993 \ldots \ldots \ldots$ & 376 & 0.255 & 3.45 & 35,949 \\
\hline$\ldots \ldots \ldots \ldots \ldots \ldots \ldots$ & 387 & 0.239 & 3.31 & 39,462 \\
\hline $2001 \ldots \ldots \ldots \ldots \ldots \ldots \ldots \ldots$ & 418 & 0.237 & 3.50 & 42,975 \\
\hline 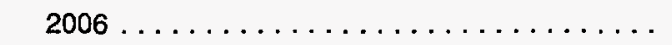 & 445 & 0.233 & 3.69 & 46,487 \\
\hline \multicolumn{5}{|l|}{ Pressurized-Water Reactor } \\
\hline $1993 \ldots \ldots \ldots$ & 339 & 0.304 & 3.52 & 33,928 \\
\hline $1997 \ldots \ldots \ldots$ & 349 & 0.271 & 3.40 & 39,196 \\
\hline $2001 \ldots \ldots \ldots \ldots \ldots \ldots \ldots \ldots$ & 377 & 0.258 & 3.68 & 44,464 \\
\hline 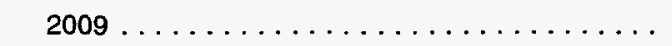 & 401 & 0.245 & 3.96 & 49,732 \\
\hline
\end{tabular}

${ }^{a}$ MWDT/MTU = Megawattdays thermal per metric ton uranium.

Source: Energy Information Administration, Office of Coal, Nuclear, Electric, and Alternate Fuels, Analysis and Systems Division, working papers, April 1994. 
number of effective full-power days for the cycle and a discharge burnup level. The years the fuel plan is used in the calculation of fuel requirements is noted in Tables B6 and B7. Trends in burnup and number of effective full-power day plans were obtained from utility-supplied data and industry experts.

The following five steps were used to develop fuel models consistent with increases in fuel burnup and the number of effective full-power days per cycle. The procedure was applied separately to generic boilingwater reactors and pressurized-water reactors and for domestic and foreign reactors.

1. The mean core-specific power (ratio of megawatts thermal to core weight in metric tons of uranium) was converted separately for the boiling-water and pressurized-water reactors in the forecast data base.

2. The core fraction associated with a given burnup level and number of effective full-power days was computed by Equation (8).

3. The specified burnup level and the core fraction calculated in step 2 were used to estimate the enrichment assay. In the domestic fuel management plans for years 1994-2004 for BWR's and 1994-2002 for PWR's, Equations (3) and (4) were used to estimate the enrichment assay. For the remaining years, Equation (7) was used to estimate the change in the enrichment assay, based on the increased burnup and change in core fraction.

4. The amount of uranium to be loaded was calculated as the product of the core fraction computed in step 2 and the total core weight.

5. Two types of adjustments were made to the enrichment assays estimated in step 3: (1) boiling-water reactor enrichments were adjusted downward by a small amount in the post- 2000 period, to account for anticipated improvements in fuel utilization; (2) an enrichment adjustment of +0.2 percent was made to the Japanese enrichments. Historically, Japanese utilities have been very conservative when ordering nuclear fuel and have typically loaded fuel with higher reactivity levels in their reactors than the fuel customarily loaded in the West to obtain comparable burnup levels. This phenomenon is also evident in the higher U-235 enrichment content of the discharged fuel.

\section{The Models}

\section{International Nuclear Model PC Version}

The estimates of the nuclear fuel cycle requirements in this report were produced with the International Nuclear Model PC Version (PCINM). This model was developed under contract for the Office of Coal, Nuclear, Electric and Alternate Fuels in the Energy Information Administration (EIA). ${ }^{122}$ The PCINM is used to simulate nuclear fuel cycle operations.

The data for the PCINM include the following general categories:

- Operating Reactor Data. This is a list of information on nuclear reactors assumed to be operable during the time period being analyzed. For each reactor, the list includes the name, start and retirement dates, net summer capability, generic category to which the reactor is assigned, indicators of the fuel management plans to be used, and the applicable dates for the fuel management plans.

- Generic Reactor Data. Each operating reactor is classified into one of the generic categories, such as boiling-water reactor and pressurizied-water reactor. The data for the generic categories of reactors include capacity factors, thermal efficiency, maintenance priority, and a list of allowable fuel management plans.

- Fuel Management Data. The data describing a fuel management plan are used to simulate the internal workings of operating reactors. Fuel management data consist of the following: fullpower days, capacity factors, kilograms of enriched uranium per megawatt of capacity loaded during each refueling, spent fuel discharged, assays of the fissile isotopes in the fuel loaded and discharged, and fraction of core replaced.

- Fuel Cycle Parameters. These data items include lead and lag times from the start of a cycle for the fuel cycle processes (that is, conversion,

${ }^{122}$ Z. Incorporated, International Nuclear Model, Personal Computer (PCINM) (Silver Spring, MD, 1992). 
enrichment, fabrication, spent fuel disposal), tails assays for enrichment services, ${ }^{123}$ process mass-loss factors, and process waste production.

- Control/Scenario Data. The user can specify data such as annual capacity factors for all equilibrium cycles.

Annual requirements for uranium concentrate $\left(\mathrm{U}_{3} \mathrm{O}_{8}\right)$ and enrichment services, as well as discharges of spent fuel, are a function of the fuel management plan being used by each reactor and the specified tails assay for enrichment services. To calculate the annual requirements, the date for the start of a cycle is determined for each reactor by a formula that uses (a) the number of full-power days specified in the fuel management plan and (b) the capacity factor. A "full-power day" is the equivalent of 24 hours of full-power operation of a reactor. The length of the cycle can then be determined as follows:

\section{Length of cycle $=$ (number of full-power days) $/($ capacity factor).}

The length of the cycle includes the time during which electricity is being generated and the time during which the reactor is not operating (such as during refueling).

The lead times for fuel cycle services must also be incorporated: $\mathrm{U}_{3} \mathrm{O}_{8}$ is delivered to a conversion plant 15 months before the restart of the nuclear unit, and enrichment services begin 12 months before the restart of the unit. Finally, the quantities of $\mathrm{U}_{3} \mathrm{O}_{8}$ and enrichment services required are determined from the amount of enriched uranium specified in the fuel management plan and from the enriched product assay and transaction tails assay. For a new reactor, the fuel management data and the lead times for the initial cycles are unique. After a reactor has reached equilibrium, the full-power days in a cycle, the quantity of fuel loaded, and the spent fuel discharged per cycle remain constant for a specific fuel management plan.

The PCINM is used to produce annual summary reports for generic reactor categories and totals for all reactors. These reports include: annual generation of electricity, annual capacity factors, annual and cumulative requirements for $\mathrm{U}_{3} \mathrm{O}_{8}$ and enrichment services, annual discharges of spent fuel, and total spent fuel discharges less the spent fuel withdrawn for reprocessing. The uranium concentrate requirements are reported as requirements for $\mathrm{U}_{3} \mathrm{O}_{8}$ or "yellowcake"; the enrichment service requirements are measured in separative work units; and the discharges of spent fuel are expressed in metric tons of initial heavy metal. The projected discharges of spent fuel exclude discharged fuel that is designated for reinsertion.

\section{Uranium Market Model}

\section{Overview}

The Uranium Market Model (UMM), which was used for most of the uranium projections in this report, is a microeconomic model in which uranium supplied by the mining and milling industry is used to meet the demand for uranium by electric utilities with nuclear power plants. Uranium is measured on a $\mathrm{U}_{3} \mathrm{O}_{8}$ concentrate equivalent basis. The input data encompass every major production center and utility on a worldwide basis. The model provides annual projections for each major uranium production and consumption region in the world. Sixteen regions were used in this study: (1) the United States, (2) Canada, (3) Australia, (4) South Africa, (5) Other Africa, (6) Western Europe, (7) Latin America, (8) the East, (9) Other, (10) Eastern Europe, (11) Russia, (12) Kazakhstan, (13) Uzbekistan, (14) Ukraine, (15) Kyrgyz Republic, and (16) Other Former Soviet Union. Production centers and utilities were identified as being in one of the 16 regions.

\section{Uranium Demand}

Uranium demand is assumed to equal near-term unfilled requirements on the part of utilities. Unfilled requirements are determined by subtracting current contract commitments at firm (non-spot) prices and inventory drawdown from total reactor requirements plus any assumed inventory buildup. Contract commitments calling for price to equal the future spot prices with no firm floor price are thus included in the calculation of uranium demand. In this way, demands may be placed on the market by uranium producers with such contracts when the spot price falls below the production costs of these producers.

The demand for uranium by electric utilities with nuclear power plants is a key parameter. Annual projections of reactor requirements are from EIA forecasts

\footnotetext{
${ }^{123}$ "Tails assay" refers to the concentration of the U-235 isotope in the waste stream from the enrichment process. The higher the concentration of U-235 in the waste, the lower the requirement for enrichment service but the greater the requirement for natural uranium for a given quantity of enriched uranium produced.
} 
(see Chapter 3 for domestic forecasts). In the model, individual utility requirements were combined into regional totals. These projections are assumed to be inelastic with respect to uranium prices, separative work unit prices, and tails assays. Scenarios with varying demands can be determined by using alternative inputs for projected reactor requirements.

In addition to reactor requirements, most utilities also maintain a uranium inventory as a contingency against possible disruptions in supply. The desired degree of forward inventory coverage varies by countries, due to such factors as national policies, contracting approaches, and regulatory treatment of inventory costs. These variations are incorporated in the model. Inventory demand is a function of future reactor requirements and future uranium prices which change from year to year. This demand is elastic with respect to the spot price and, in line with market behavior, decreases as the price falls and increases as the price rises.

Contract commitments, between both producers and electric utilities and between utilities and enrichment suppliers, are taken into account exogenously. Commitments between producers and electric utilities are considered in two ways. The first is an estimate of the overcommitments by utilities to purchase uranium in excess of their annual reactor requirements. The second represents producer-utility contracts by specifying the commitments made by producers to deliver uranium from a specific production center to a particular utility. Contracts between utilities and enrichment suppliers can also lead to overcommitments in terms of the utility buying uranium for committed deliveries to enrichment plants that exceed the utility's reactor requirements.

\section{Uranium Supply}

Uranium supply is represented by an annual short-run supply curve consisting of increments of potential production and the supply of excess inventories which are assumed to be available at different market prices. Production centers are defined as mine-mill combinations, if there is conventional production, and as processing facilities for nonconventional production. Also included are producers in Western countries, Eastern Europe, the Former Soviet Union, and China that are potential net exporters. In general, production centers come on line, produce uranium, and deplete their reserves depending on a number of geologic, engineering, market, and political conditions. Producers that are able to produce and sell uranium most cheaply generally occupy the lower portions of the supply curve. Production costs are estimated exogenously, taking the following into account: the size of the reserves; annual production capacity; ore grade; type of production; capital, labor, and other costs; and taxes and royalty requirements. A fair market rate of return is also assumed. Government subsidies, variations in exchange rates, floor prices, supply disruptions, or other factors may affect the shape of the supply curve each year.

Some excess utility inventories are also treated as sources of potential supply that may be drawn down or sold in the secondary market. The size of these yearly drawdowns and sales depends on the utility's desired level of contingency stocks, spot-market prices, and the utility's general propensity to draw down its stocks; or to sell uranium in the secondary market. Thus, each utility's inventory level varies annually depending on its projected reactor requirements, its contract comrnitments with producers and enrichment suppliers, the trend in market prices, its own inventory planning strategy, and the sales of excess inventories held by suppliers and governments.

\section{Market-Clearing Conditions}

Equilibrium is achieved in the forecasts when the supply of urarium meets the demand for uranium. Supply comes from production centers; utilities' inventories, which may already be at levels sufficient to satisfy inventory demand; excess inventories held by suppliers and governments; and utilities' excess inventories which are drawn down or sold in the secondary market. ${ }^{124}$ Demand consists of utility reactor requirements, contingency inventory demand, and any additional market demand resulting from contract overcommitments with either producers or enrichment facilities.

The market projections in any given year are determined by activities in previous years, such as market prices and decisions to defer production of reserves; the demand levels for projection years are affected by reactor requirements in future years. Unanticipated changes in future demand may be introduced exogenously so that market activities in any forecast year may be constrained by actions taken in previous years.

\footnotetext{
${ }^{124}$ Loans of uranium among the various suppliers and users are not modeled as such. Borrowing and lending activities do not alter the total inventories of uranium, but they do delay the purchase of newly produced uranium. This effect can be modeled by assuming that the inventories of uranium that are not held by utilities or producers remain constant at their current level.
} 
Under free-market conditions with a single world market, utilities may draw down their inventories either for their own use or for sale in the secondary market; production is allocated to satisfy contract commitments; and remaining demand is met by producers with uncommitted reserves and by other suppliers with holdings of uranium. The intersection of this supply curve with the unfilled demand identifies the particular production and other supply increments that are sold in the market and defines the equilibrium spot-market price for that year. These sales, together with those from contract commitments, are tabulated to give projections of production in the United States and in other regions. ${ }^{125}$ The equilibrium spot-market price and the 1-year lagged spot-market price are used to compute a projected spot-market price. Projected prices for new contracts are estimated as a function of the projected spot-market price. The net imports of a country are calculated from its utilities' reactor requirements, contingency inventory demand, contract commitments, inventory use, and its producers' sales.

${ }^{125}$ In projecting production in the United States and other regions, the modeling system considers only those contract commitments that are tied to specific production centers at firm prices. For this reason, the model in some instances projects production at lower levels than contract commitments. 

Appendix C

\section{World Nuclear Units Operable as of December 31, 1993}

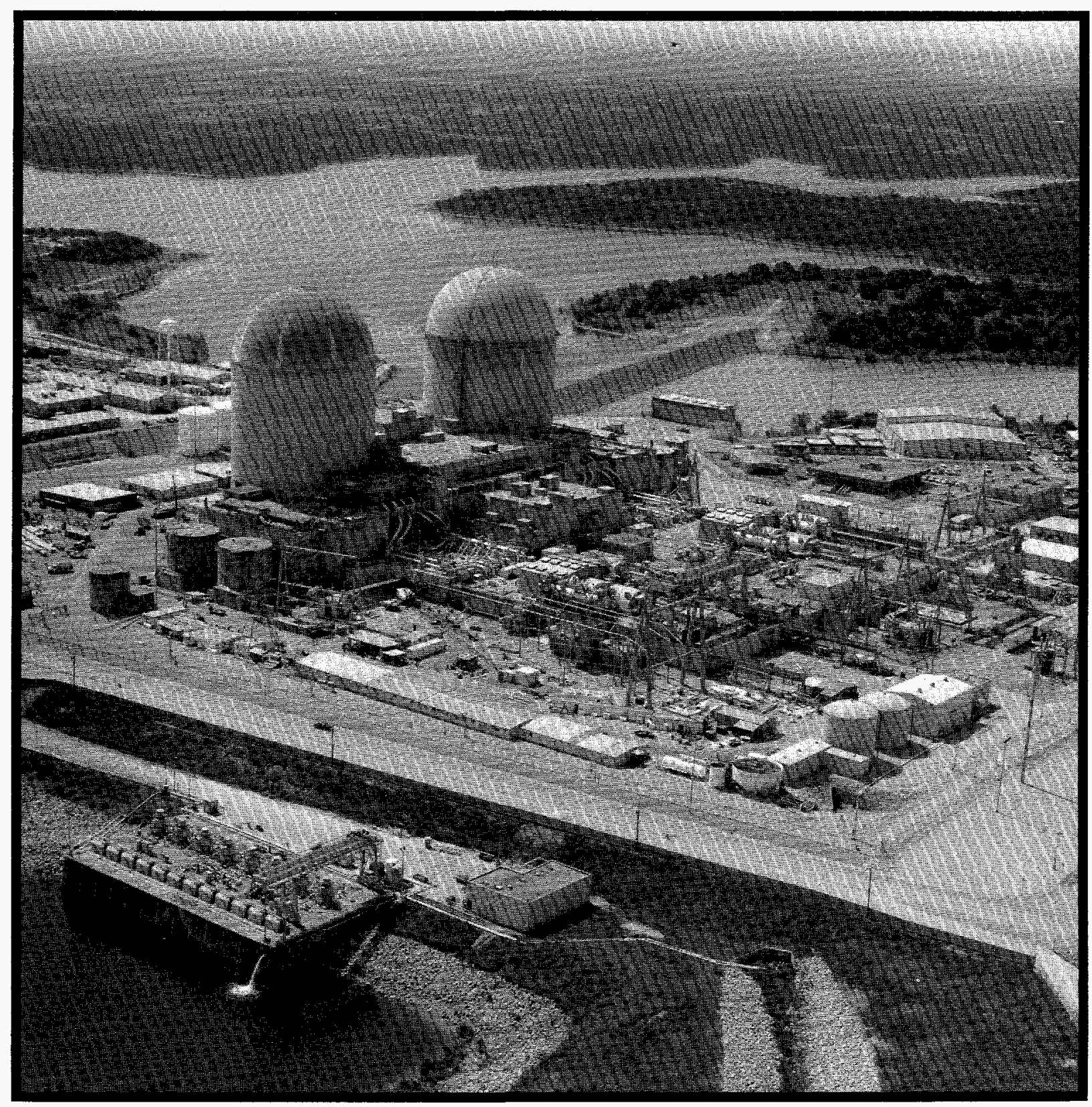

Texas Utilities Electric Company's Comanche Peak 2, a 1,150-MWe BWR, was connected to the electrical grid in April 1993. The plant has a combined capacity of 2,300 net $M W e$. 


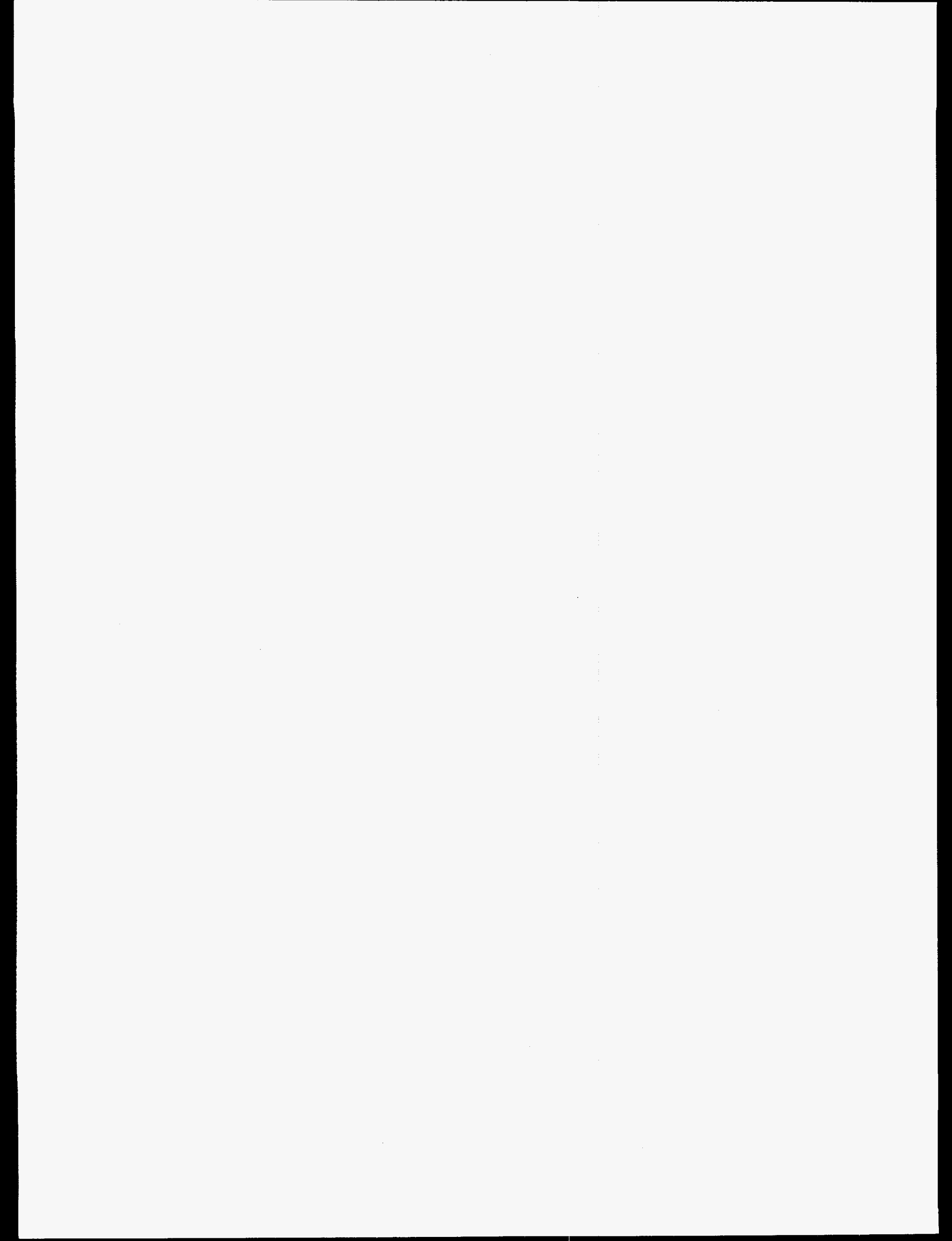




\section{Appendix C}

\section{World Nuclear Units Operable as of December 31, 1993}

Table C1. Roster of Nuclear Generating Units Operable as of December 31, $1993^{a}$

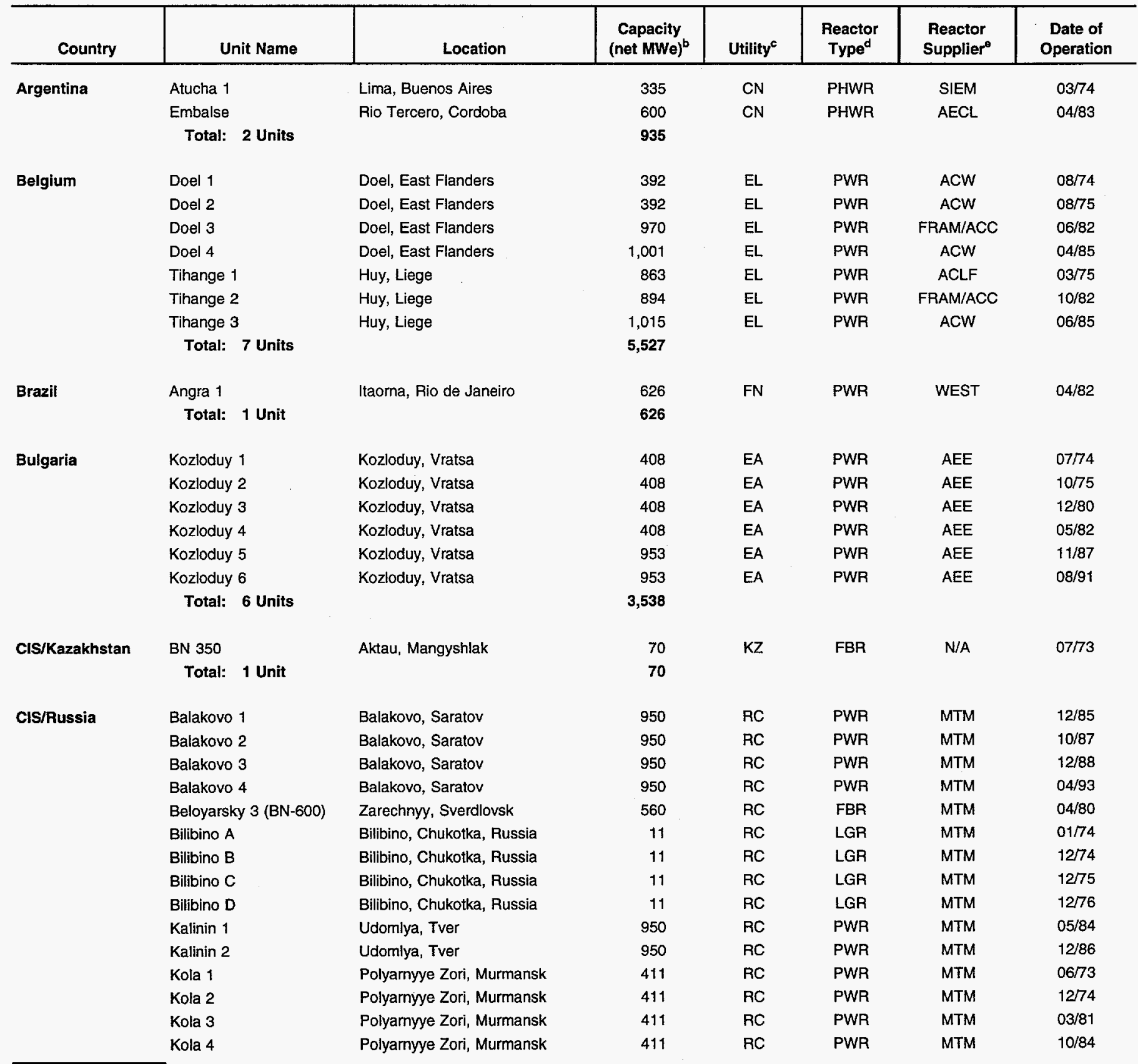

See footnotes at end of table. 
Table C1. Roster of Nuclear Generating Units Operable as of December 31, 1993 (Continued)

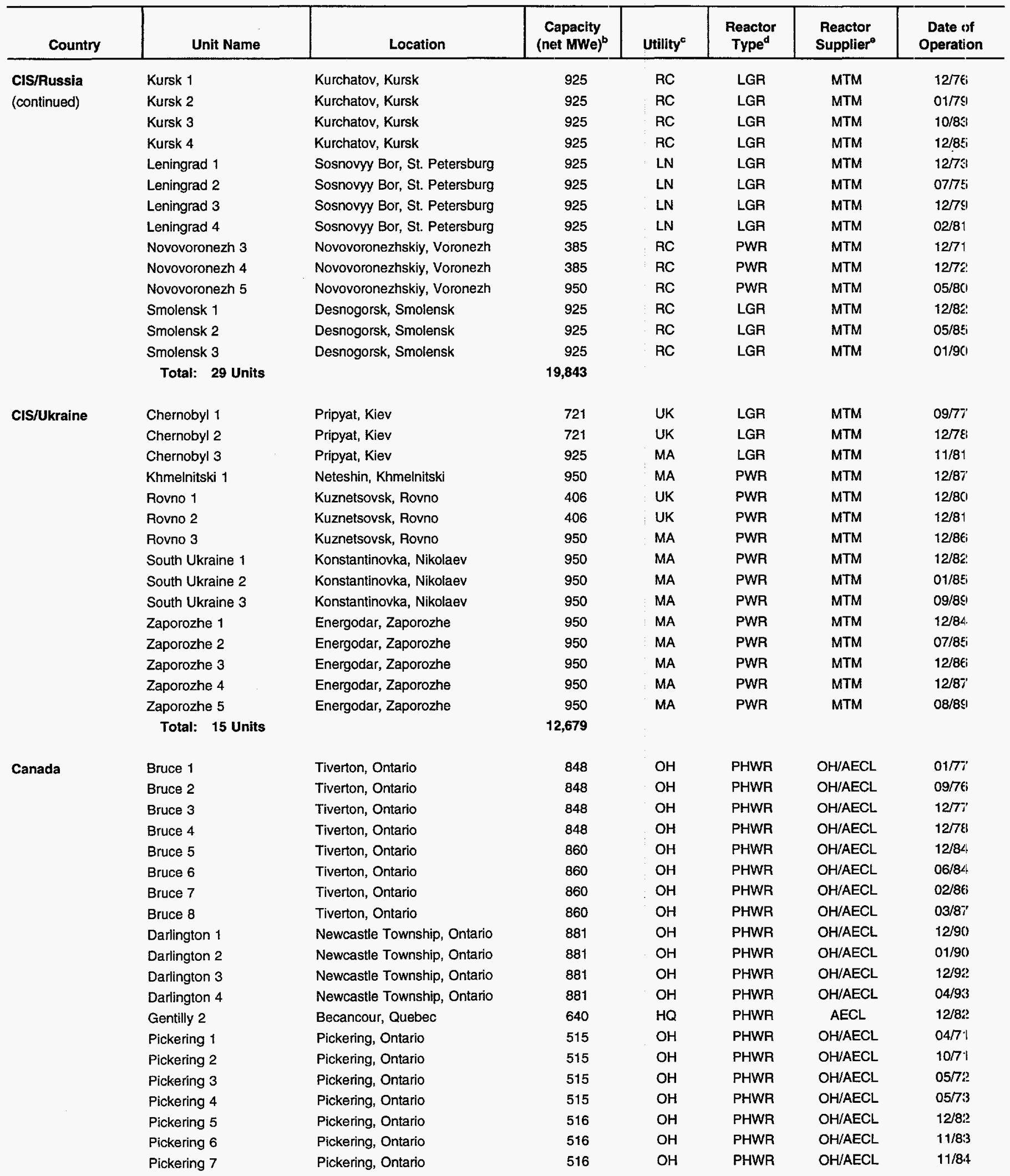

See footnotes at end of table. 
Table C1. Roster of Nuclear Generating Units Operable as of December 31, 1993 (Continued)

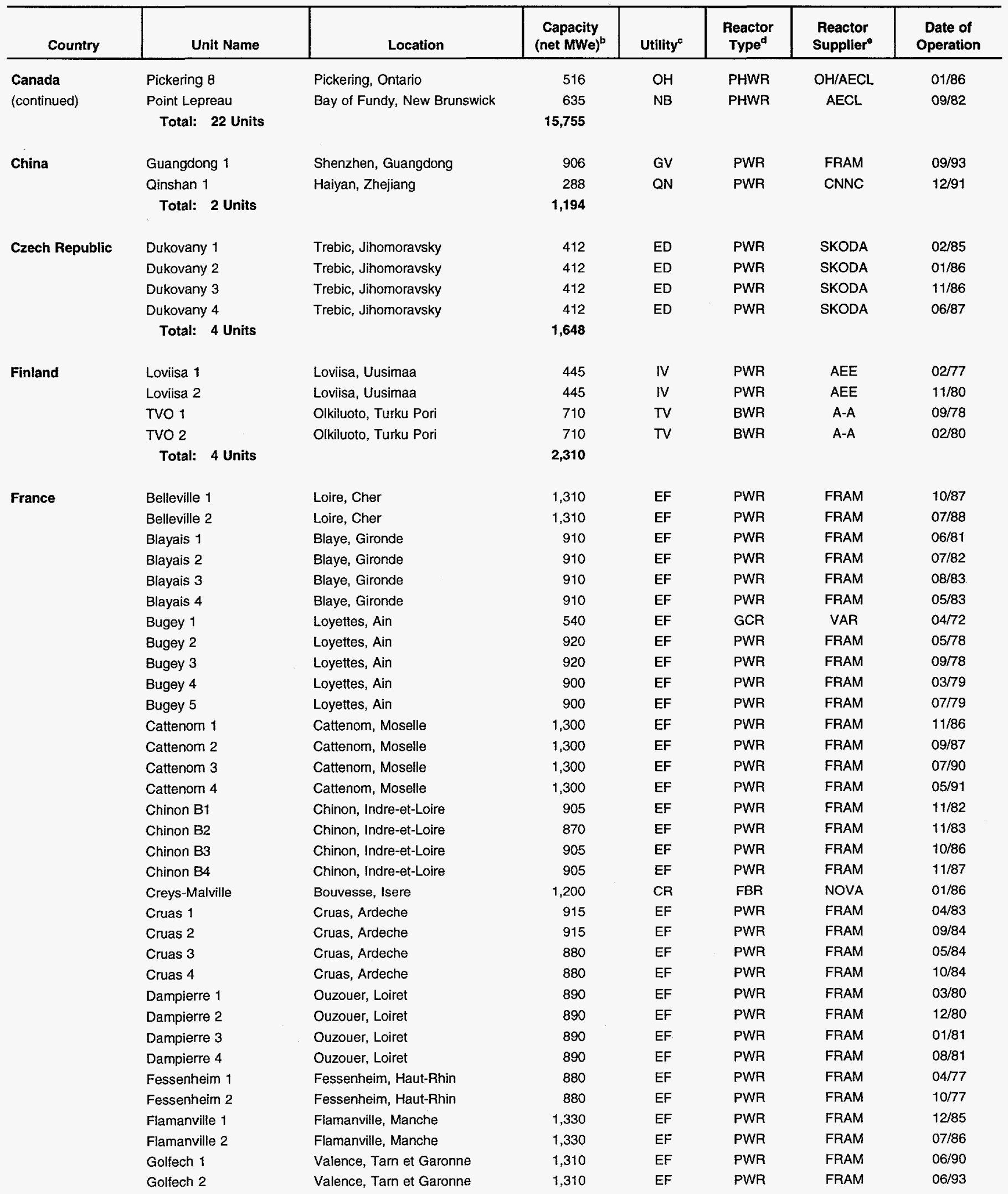

See footnotes at end of table. 
Table C1. Roster of Nuclear Generating Units Operable as of December 31, 1993 (Continued)

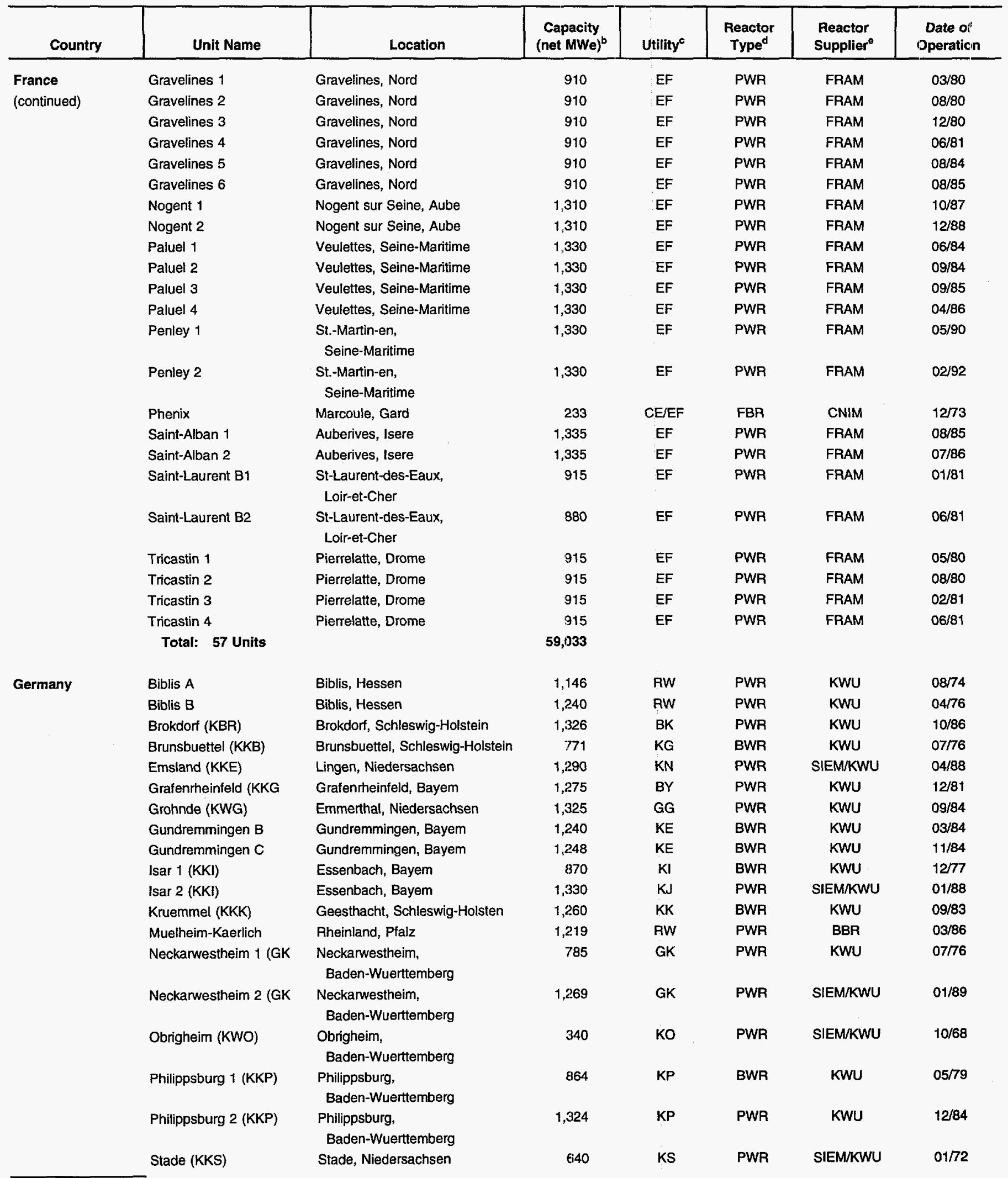

See footnotes at end of table. 
Table C1. Roster of Nuclear Generating Units Operable as of December 31, 1993 (Continued)

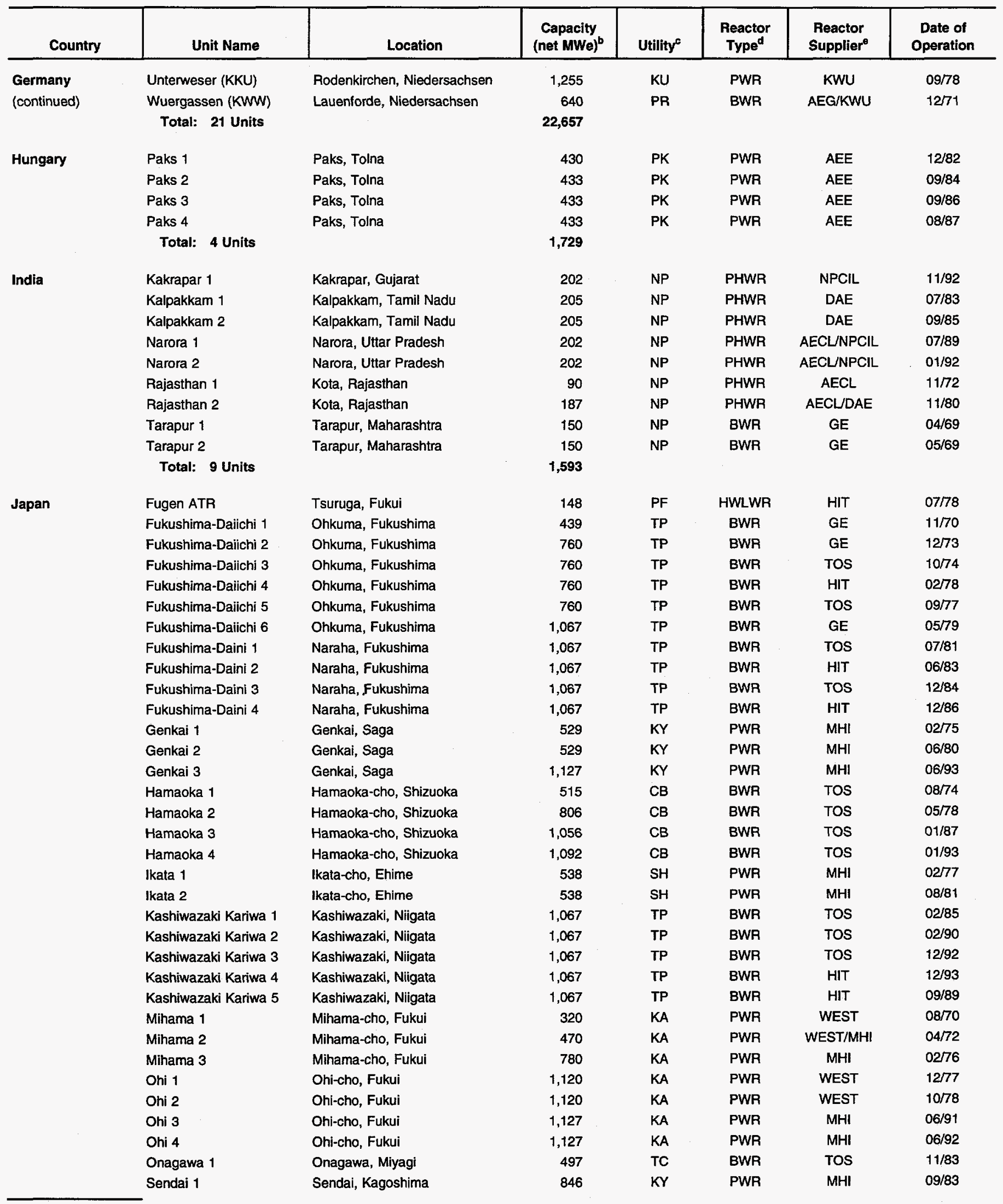

See footnotes at end of table. 
Table C1. Roster of Nuclear Generating Units Operable as of December 31, 1993 (Continued)

\begin{tabular}{|c|c|c|c|c|c|c|c|}
\hline Country & Unit Name & Location & $\begin{array}{c}\text { Capacity } \\
\text { (net MWe) }\end{array}$ & Utility & $\begin{array}{l}\text { Reactor } \\
\text { Type }^{d}\end{array}$ & $\begin{array}{l}\text { Reactor } \\
\text { Supplier }\end{array}$ & $\begin{array}{c}\text { Date of } \\
\text { Operation }\end{array}$ \\
\hline Japan & Sendai 2 & Sendai, Kagoshima & 846 & $\mathrm{KY}$ & PWR & MHI & $04 / 85$ \\
\hline \multirow[t]{14}{*}{ (continued) } & Shika 1 & Shika-machi, Ishikawa & 505 & HU & BWR & HIT & $01 / 93$ \\
\hline & Shimane 1 & Kashima-cho, Shimane & 439 & CK & BWR & HIT & $12 / 73$ \\
\hline & Shimane 2 & Kashima-cho, Shimane & 790 & CK & BWR & HIT & $07 / 88$ \\
\hline & Takahama 1 & Takahama-cho, Fukui & 780 & KA & PWR & WEST & $03 / 74$ \\
\hline & Takahama 2 & Takahama-cho, Fukui & 780 & KA & PWR & MHI & $01 / 75$ \\
\hline & Takahama 3 & Takahama-cho, Fukui & 830 & $K A$ & PWR & MHI & $05 / 84$ \\
\hline & Takahama 4 & Takahama-cho, Fukui & 830 & KA & PWR & MHI & $11 / 84$ \\
\hline & Tokai 1 & Tokai Mura, Ibaraki & 159 & $J P$ & GCR & GEC & $11 / 65$ \\
\hline & Tokai 2 & Tokai Mura, Ibaraki & 1,080 & $J P$ & BWR & GE & $03 / 78$ \\
\hline & Tomari 1 & Tomari-mura, Hokkaido & 550 & HD & PWR & MHI & $12 / 88$ \\
\hline & Tomari 2 & Tomari-mura, Hokkaido & 550 & HD & PWR & MHI & $08 / 90$ \\
\hline & Tsuruga 1 & Tsuruga, Fukui & 341 & $J P$ & BWR & GE & $11 / 69$ \\
\hline & Tsuruga 2 & Tsuruga, Fukui & 1,115 & $J P$ & PWR & MHI & $06 / 86$ \\
\hline & Total: 48 Units & & 38,029 & & & & \\
\hline \multirow[t]{10}{*}{ Korea, South } & Kori 1 & Kori, Kyongnam & 556 & $\mathrm{KR}$ & PWR & WEST & $06 / 77$ \\
\hline & Kori 2 & Kori, Kyongnam & 605 & KR & PWR & WEST & $04 / 83$ \\
\hline & Kori 3 & Kori, Kyongnam & 895 & KR & PWR & WEST & $01 / 85$ \\
\hline & Kori 4 & Kori, Kyongnam & 895 & KR & PWR & WEST & $11 / 85$ \\
\hline & Ulchin 1 & Ulchin, Kyongbuk & 920 & KR & PWR & FRAM & $04 / 88$ \\
\hline & Ulchin 2 & Ulchin, Kyongbuk & 920 & KR & PWR & FRAM & $04 / 89$ \\
\hline & Wolsong 1 & Kyongju, Kyongbuk & 629 & KR & PHWR & AECL & $12 / 82$ \\
\hline & Yonggwang 1 & Yonggwang, Chonnam & 900 & KR & PWR & WEST & $03 / 86$ \\
\hline & Yonggwang 2 & Yonggwang, Chonnam & 900 & KR & PWR & WEST & $11 / 86$ \\
\hline & Total: 9 Units & & 7,220 & & & & \\
\hline \multirow[t]{3}{*}{ Lithuania } & Ignalina 1 & Snieckus, Lithuania & 1,185 & MA & LGR & MTM & $12 / 83$ \\
\hline & Ignalina 2 & Snieckus, Lithuania & 1,185 & MA & LGR & MTM & $08 / 87$ \\
\hline & Total: 2 Units & & 2,370 & & & & \\
\hline \multirow[t]{2}{*}{ Mexico } & Laguna Verde 1 & Laguna Verde, Veracruz & 654 & FC & BWA & GE & $04 / 89$ \\
\hline & Total: 1 Unit & & 654 & & & & \\
\hline \multirow[t]{3}{*}{ Netherlands } & Borssele & Borssele, Zeeland & 449 & $\mathbf{P Z}$ & PWR & KWU & $07 / 73$ \\
\hline & Dodewaard & Dodewaard, Gelderland & 55 & GN & BWR & GE & $10 / 68$ \\
\hline & Total: 2 Units & & 504 & & & & \\
\hline \multirow[t]{2}{*}{ Pakistan } & Kanupp & Karachi, Sind & 125 & $\mathrm{PA}$ & PHWR & CGE & $10 / 71$ \\
\hline & Total: 1 Unit & & 125 & & & & \\
\hline \multirow[t]{5}{*}{ Slovak Republic } & Bohunice 1 & Trnava, Zapadoslovensky & 408 & $\mathrm{~EB}$ & PWR & AEE & $12 / 78$ \\
\hline & Bohunice 2 & Trnava, Zapadoslovensky & 408 & $\mathrm{~EB}$ & PWR & AEE & $03 / 80$ \\
\hline & Bohunice 3 & Trnava, Zapadoslovensky & 408 & EB & PWR & SKODA & $08 / 84$ \\
\hline & Bohunice 4 & Trnava, Zapadoslovensky & 408 & EB & PWR & SKODA & $08 / 85$ \\
\hline & Total: 4 Units & & 1,632 & & & & \\
\hline \multirow[t]{2}{*}{ Slovenia } & Krsko & Krsko, Vribina & 632 & NR & PWR & WEST & $10 / 81$ \\
\hline & Total: 1 Unit & & 632 & & & & \\
\hline \multirow[t]{3}{*}{ South Africa } & Koeberg 1 & Melkbosstrand, Capetown & 921 & EK & PWR & FRAM & $04 / 84$ \\
\hline & Koeberg 2 & Melkbosstrand, Capetown & 921 & EK & PWR & FRAM & $07 / 85$ \\
\hline & Total: 2 Units & & 1,842 & & & & \\
\hline
\end{tabular}

See footnotes at end of table. 
Table C1. Roster of Nuclear Generating Units Operable as of December 31, 1993 (Continued)

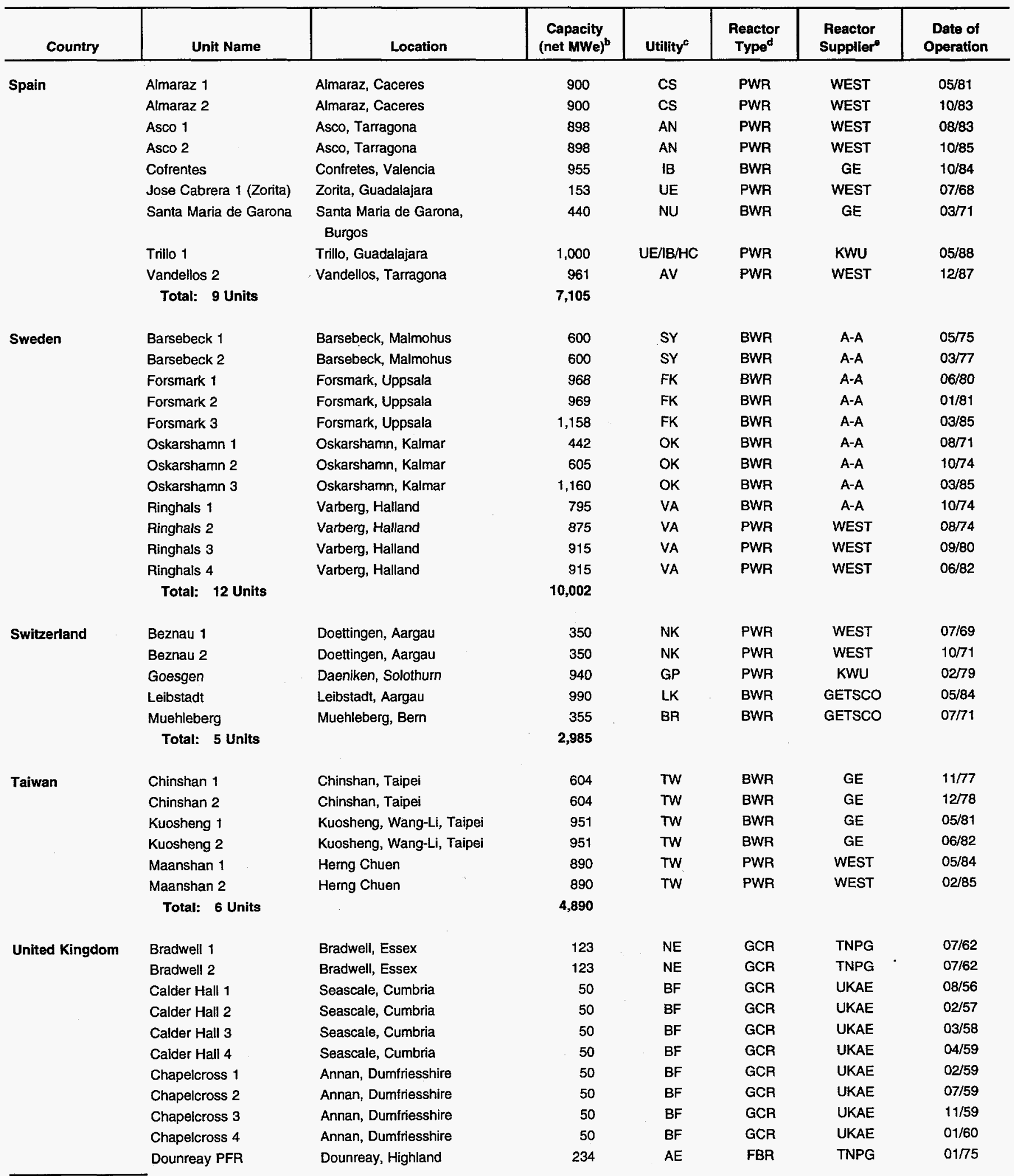

See footnotes at end of table. 
Table C1. Roster of Nuclear Generating Units Operable as of December 31, 1993 (Continued)

\begin{tabular}{|c|c|c|c|c|c|c|c|}
\hline Country & Unit Name & Location & $\begin{array}{c}\text { Capacity' } \\
\text { (net } M W e)^{b}\end{array}$ & Utility $^{c}$ & $\begin{array}{c}\text { Reactor } \\
\text { Typed }\end{array}$ & $\begin{array}{c}\text { Reactor } \\
\text { Supplier }\end{array}$ & $\begin{array}{c}\text { Date of } \\
\text { Operation }\end{array}$ \\
\hline \multirow{25}{*}{$\begin{array}{l}\text { United Kingdom } \\
\text { (continued) }\end{array}$} & Dungeness A1 & Lydd, Kent & 220 & NE & GCR & TNPG & $09 / 155$ \\
\hline & Dungeness A2 & Lydd, Kent & 220 & NE & GCR & TNPG & $11 / 65$ \\
\hline & Dungeness B1 & Lydd, Kent & 555 & NE & AGR & APC & $04 / 133$ \\
\hline & Dungeness $\mathrm{B} 2$ & Lydd, Kent & 555 & NE & AGR & APC & $12 / 135$ \\
\hline & Hartlepool A1 & Hartlepool, Cleveland & 605 & NE & AGR & NPC & $08 / 133$ \\
\hline & Hartlepool A2 & Hartlepool, Cleveland & 605 & NE & AGR & NPC & $10 / 134$ \\
\hline & Heysham A1 & Heysham, Lancashire & 575 & NE & AGR & NPC & $07 / 83$ \\
\hline & Heysham A2 & Heysham, Lancashire & 575 & NE & AGR & NPC & $10 / 34$ \\
\hline & Heysham B1 & Heysham, Lancashire & 625 & NE & AGR & NPC & $07 / 88$ \\
\hline & Heysham B2 & Heysham, Lancashire & 625 & NE & AGR & NPC & $11 / 88$ \\
\hline & Hinkley Point A1 & Hinkley Point, Somerset & 235 & NE & GCR & EBT & $02 / 65$ \\
\hline & Hinkley Point A2 & Hinkley Point, Somerset & 235 & NE & GCR & EBT & $03 / 655$ \\
\hline & Hinkley Point B1 & Hinkley Point, Somerset & 585 & NE & AGR & TNPG & $10 / 76$ \\
\hline & Hinkley Point B2 & Hinkley Point, Somerset & 610 & NE & AGR & TNPG & $02 / 76$ \\
\hline & Hunterston B1 & Ayrshire, Strathclyde & 575 & SC & AGR & TNPG & $02 / 76$ \\
\hline & Hunterston B2 & Ayrshire, Strathclyde & 575 & SC & AGR & TNPG & $03 / 7$ \\
\hline & Oidbury 1 & Oldbury, Avon & 217 & NE & GCR & TNPG & $11 / 67$ \\
\hline & Oldbury 2 & Oldbury, Avon & 217 & NE & GCR & TNPG & $04 / 68$ \\
\hline & Sizewell A1 & Sizewell, Suffolk & 210 & NE & GCA & EBT & $01 / 66$ \\
\hline & Sizewell A2 & Sizewell, Suffolk & 210 & NE & GCR & EBT & $04 / 66$ \\
\hline & Torness 1 & Dunbar, East Lothian & 625 & SC & AGR & NNC & $05 / 88$ \\
\hline & Torness 2 & Dunbar, East Lothian & 625 & SC & AGR & NNC & $02 / 89$ \\
\hline & Wylfa 1 & Anglesey, Wales & 475 & NE & GCR & EBT & $01 / 71$ \\
\hline & Wylfa 2 & Anglesey, Wales & 475 & NE & GCR & EBT & $07 / 71$ \\
\hline & Total: 35 Units & & 11,909 & & & & \\
\hline \multirow[t]{26}{*}{ United States } & 3 Mile Island 1 & Middletown, Pennsylvania & 786 & GU & PWR & $B \& W$ & $06 / 74$ \\
\hline & Arkansas Nuclear 1 & Russellville, Arkansas & 836 & AK & PWR & B\&W & $5 / 74$ \\
\hline & Arkansas Nuclear 2 & Russellville, Arkansas & 858 & AK & PWR & C-E & $12 / 73$ \\
\hline & Beaver Valley 1 & Shippingport, Pennsylvania & 810 & $\mathrm{DL}$ & PWR & WEST & $07 / 7 i$ \\
\hline & Beaver Valley 2 & Shippingport, Pennsylvania & 833 & $\mathrm{DL}$ & PWR & WEST & $08 / 87$ \\
\hline & Big Rock Point & Charlevoix, Michigan & 67 & $\mathrm{CC}$ & BWR & GE & $08 / 6 ?$ \\
\hline & Braidwood 1 & Braidwood, Illinois & 1,090 & $\mathrm{CM}$ & PWR & WEST & $07 / 8 ?$ \\
\hline & Braldwood 2 & Braidwood, Illinois & 1,090 & $\mathrm{CM}$ & PWR & WEST & $05 / 813$ \\
\hline & Browns Ferry 1 & Decatur, Alabama & 1,065 & TN & BWA & GE & $12 / 73$ \\
\hline & Browns Ferry 2 & Dacatur, Alabama & 1,065 & $\mathrm{TN}$ & BWR & GE & $08 / 74$ \\
\hline & Browns Ferry 3 & Decatur, Alabama & 1,065 & $T N$ & BWR & GE & $08 / 76$ \\
\hline & Brunswick 1 & Southport, North Carolina & 767 & $\mathrm{CA}$ & BWR & GE & $11 / 76$ \\
\hline & Brunswick 2 & Southport, North Carolina & 754 & $\mathrm{CA}$ & BWR & GE & $12 / 74$ \\
\hline & Byron 1 & Byron, Illinois & 1,120 & $\mathrm{CM}$ & PWR & WEST & $02 / 85$ \\
\hline & Byron 2 & Byron, Illinois & 1,120 & $\mathrm{CM}$ & PWR & WEST & $01 / 8 i$ \\
\hline & Callaway 1 & Fulton, Missouri & 1,125 & UU & PWR & WEST & $10 / 84$ \\
\hline & Calvert Cliffs 1 & Lusby, Maryland & 830 & $B G$ & PWA & C-E & $07 / 74$ \\
\hline & Calvert Cliffs 2 & Lusby, Maryland & 830 & $B G$ & PWR & $C-E$ & $11 / 76$ \\
\hline & Catawba 1 & Clover, South Carolina & 1,129 & DP & PWR & WEST & $01 / 85$ \\
\hline & Catawba 2 & Clover, South Carolina & 1,129 & DP & PWA & WEST & $05 / 86$ \\
\hline & Clinton 1 & Clinton, Illinois & 930 & IP & BWR & GE & $04 / 87$ \\
\hline & Comanche Peak 1 & Glen Rose, Texas & 1,150 & $T X$ & PWR & WEST & $04 / 90$ \\
\hline & Comanche Peak 2 & Glen Rose, Texas & 1,150 & $T X$ & PWR & WEST & $04 / 98$ \\
\hline & Cooper 1 & Brownville, Nebraska & 778 & ND & BWR & GE & $01 / 74$ \\
\hline & Crystal Fiver 3 & Red Level, Florida & 816 & FF & PWR & B\&W & $01 / 7 i$ \\
\hline & Davis Besse 1 & Oak Harbor, Ohio & 873 & TO & PWR & $B \& W$ & $04 \pi 7$ \\
\hline
\end{tabular}

See footnotes at end of table. 
Table C1. Roster of Nuclear Generating Units Operable as of December 31, 1993 (Continued)

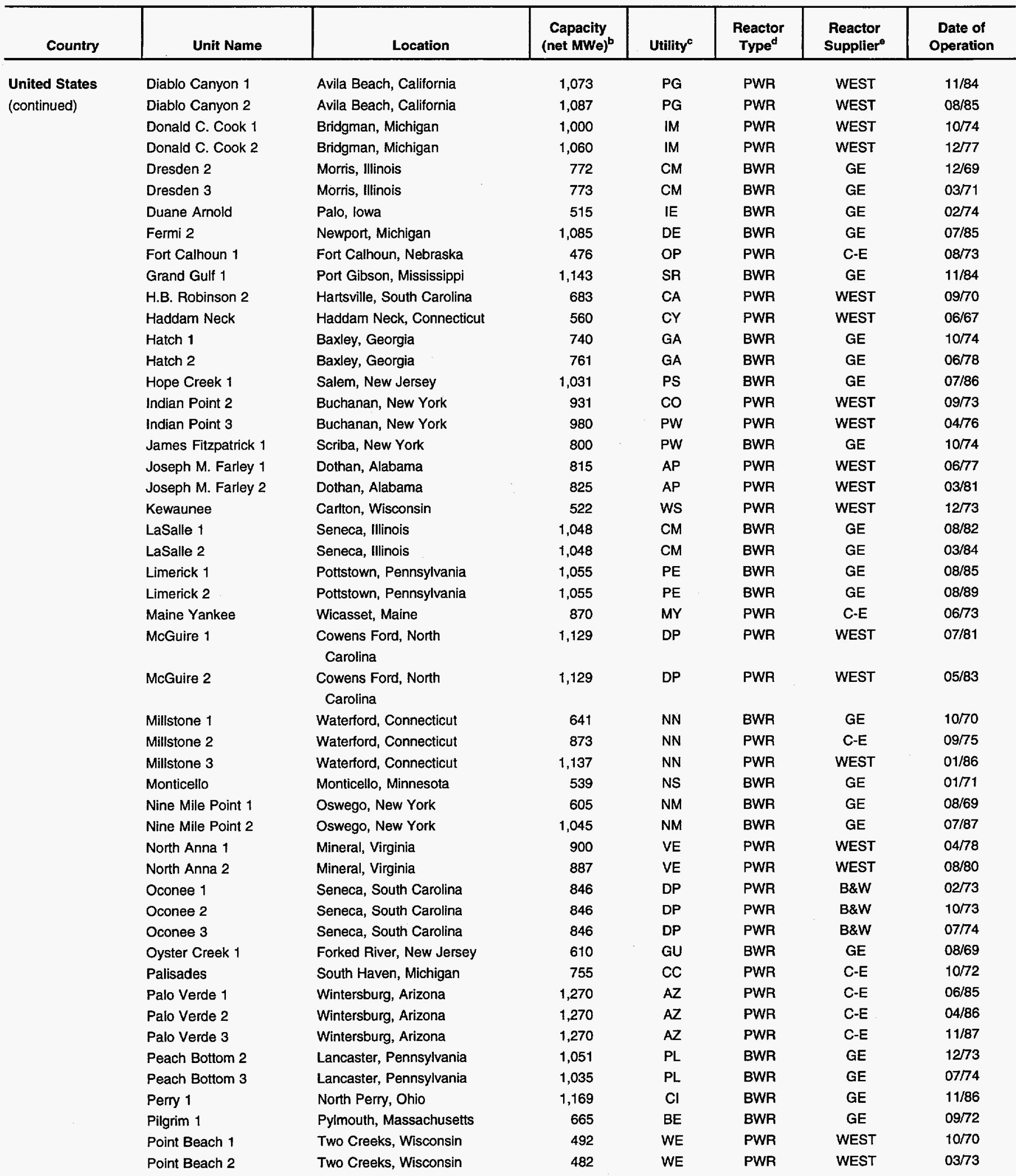

See footnotes at end of table. 
Table C1. Roster of Nuclear Generating Units Operable as of December 31, 1993 (Continued)

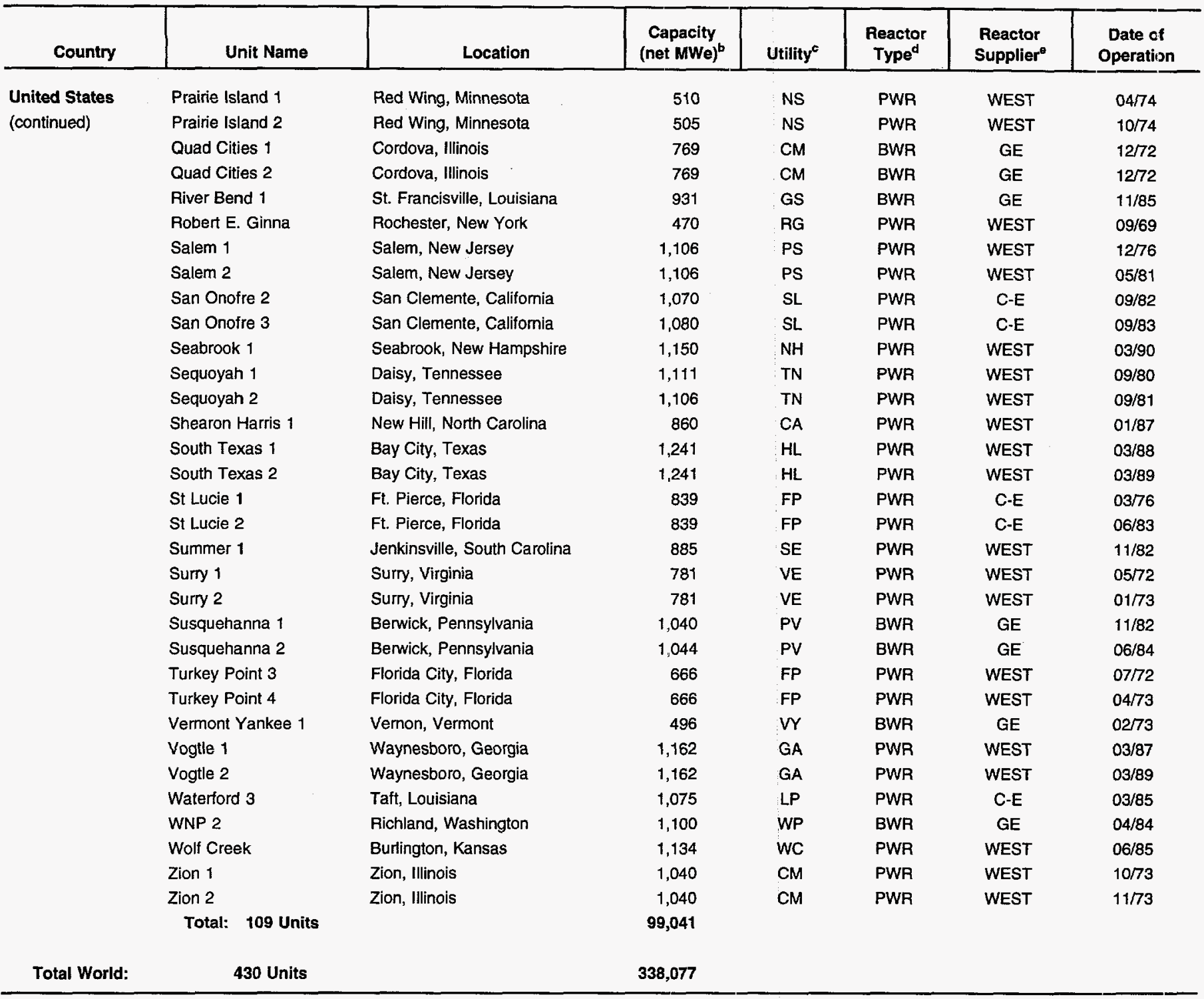

aEIA's review of the latest data sources may have resulted in revisions of names, capacities, and operation dates. For the United States, revisions are based on the Energy Information Administration (EIA) Form-860, "Annual Electric Generator Report."

$\mathrm{b}_{\mathrm{MWe}}=$ Megawatts-electric.

'See Table C2 for key to abbreviations of utility names.

'Reactor Types: AGR, advanced gas-cooled, graphite-moderated reactor; BWR, boiling light-water-cooled and moderated reactor; FBR, fast breeter reactor; GCR, gas-cooled, graphite-moderated reactor; HWLWR, heavy-water-moderated, boiling light-water-cooled reactor; LGR, light-water-cooled, graphite-moderated reactor; PHWR, pressurized heavy-water-moderated and cooled reactor; PWR, pressurized light-water-moderated and cooled reactor.

'See Table $\mathrm{C} 3$ for key to abbreviations of reactor supplier names.

I"Date of Operation" is the date foreign units were connected to the electrical grid. For U.S. units, "month operable" is the date the unit received its full-power operating license. Retired units are not included.

Note: Totals may not equal sum of components due to independent rounding.

Sources: International Atomic Energy Agency, Nuclear Power Reactors in the World (Vienna, Austria, April 1994). Energy Information Administration Form ElA860, “Annual Electric Generator Report." Nuclear Regulatory Commission, Information Digest, 1954 Edition (NUREG-0350, March 1994) for units which started operating after 1978; Program Summary Report (NUREG-0380, May 1980) for units which started operating between 1960 through 1978. 


\section{Table C2. Key to Utility Codes for Rosters of Nuclear Generating and Construction Pipeline Units}

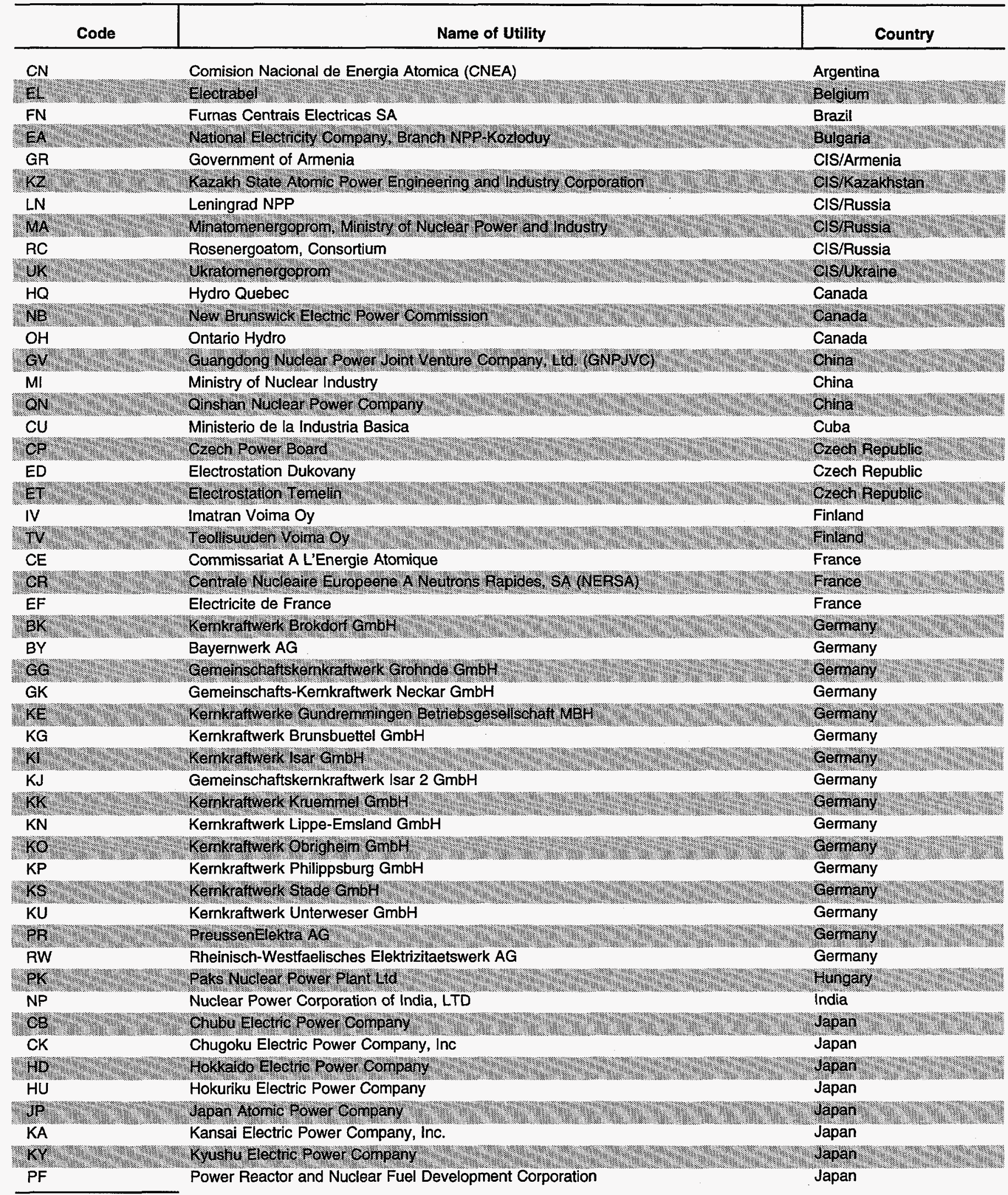


Table C2. Key to Utility Codes for Rosters of Nuclear Generating and Construction Pipeline Units (Continued)

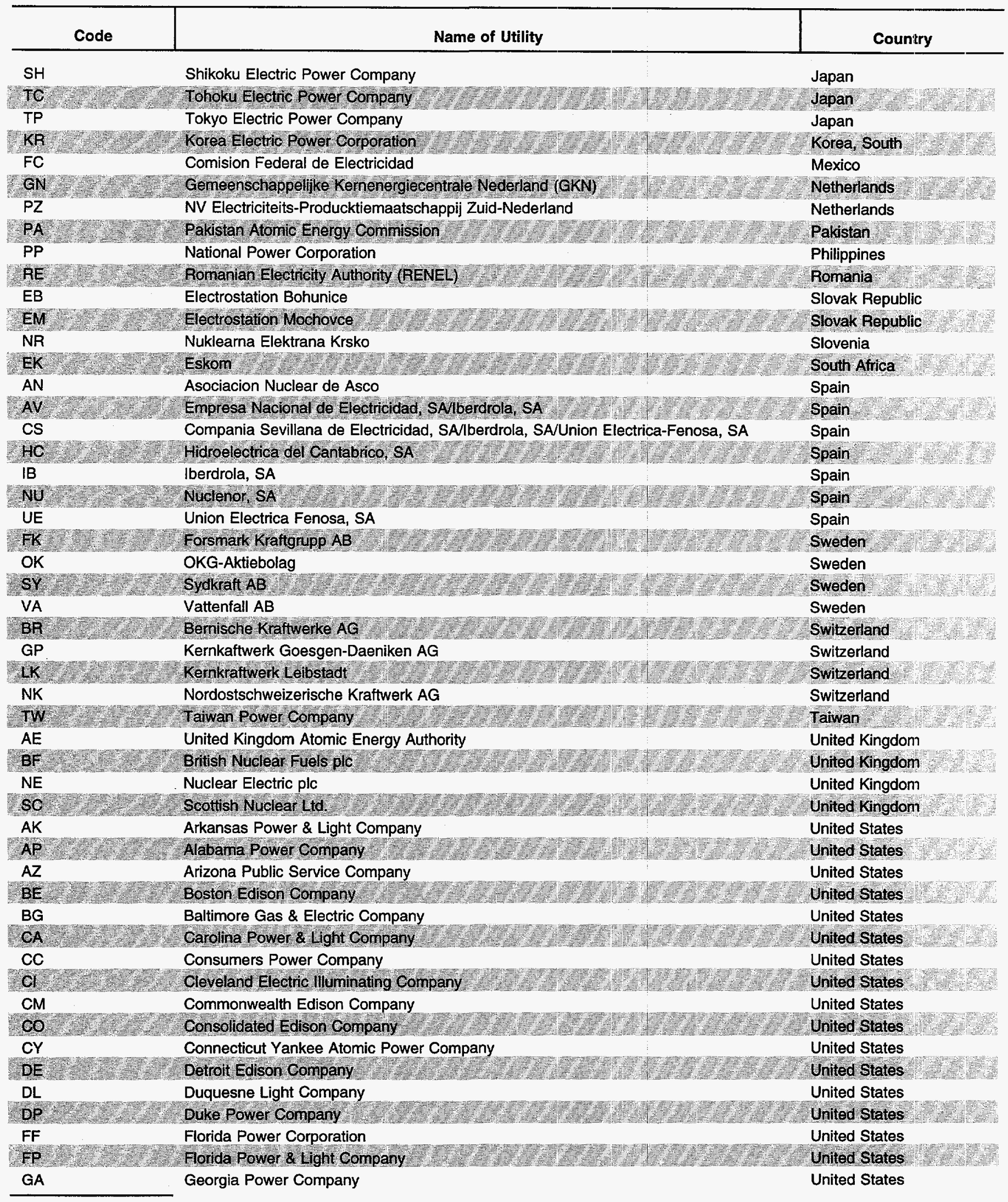


Table C2. Key to Utility Codes for Rosters of Nuclear Generating and Construction Pipeline Units (Continued)

\begin{tabular}{|c|c|c|}
\hline Code & Name of Utility & Country \\
\hline GS & Gulf States Utilities Company & United States \\
\hline GU & GPUNuclear Gorporation & United States \\
\hline HL & Houston Lighting \& Power Company & United States \\
\hline IE & lowa Electric Light \& Power Company & United States \\
\hline IM & Indiana/Michigan Power Company & United States \\
\hline & Illinois Power Company & United States \\
\hline LP & Louisiana Power \& Light Company & United States \\
\hline MY & Maine Yankee Atomic Power Company & United States \\
\hline ND & Nebraska Public Power District & United States \\
\hline NH & Public Service Company of New Hampshire & United States: \\
\hline NM & Niagra Mohawk Power Corporation & United States \\
\hline NN & Northeast Nuclear Energy Company & United States: \\
\hline NS & Northern States Power Company & United States \\
\hline $\mathrm{OP}$ & Omaha Public Power District & United States \\
\hline $\mathrm{PE}$ & Philadelphia Electric Company & United States \\
\hline PG & Pacific Gas \& Electric Company & United States \\
\hline PL & Philadelphia Electric Company/ Public Service & United States \\
\hline PS & Public Service Electric \& Gas Company & United States: \\
\hline PV & Pennsylvania Power \& Light Company & United States \\
\hline PW & Power Authority of the State of New Yolk & United States \\
\hline RG & Rochester Gas \& Electric Corporation & United States \\
\hline SE & South Garolina Electric \& Gas Company & United States \\
\hline SL & Southern California Edison Company & United States \\
\hline SR & System Energy Resources, Ine. & United States \\
\hline TN & Tennessee Valley Authority & United States \\
\hline TO & Toledo Edison Company & United States \\
\hline TX & Texas Utilities Electric Company & United States \\
\hline UU & Union Electric Company & United States \\
\hline VE & Virginia Electric \& Power Company & United States \\
\hline vy & Vermont Yankee Nuclear Power Corporation & United States \\
\hline wo & Wolf Creek Nuclear Operating Corporation & United States \\
\hline WE & Wisconsin Electric Power Company & United states \\
\hline WP & Washington Public Power Supply System & United States \\
\hline Ws & Wisconsin Public Senvice Corporation & United States \\
\hline
\end{tabular}


Table C3. Key to Reactor Supplier Codes for Rosters of Nuclear Generating and Construction Pipeline Units

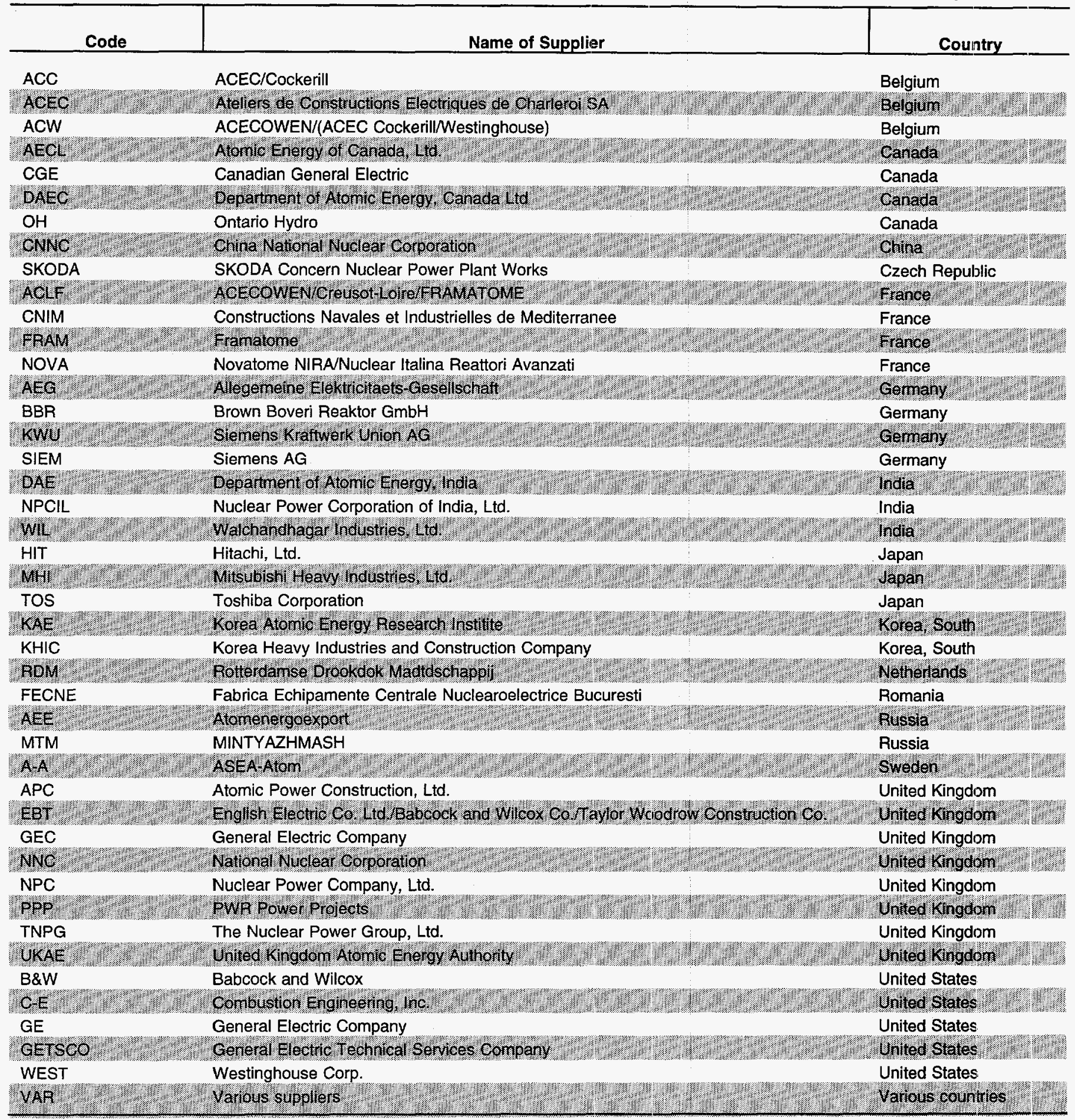


Appendix D

\section{World Nuclear \\ Generating Units \\ In the Construction \\ Pipeline as of \\ December 31, 1993}

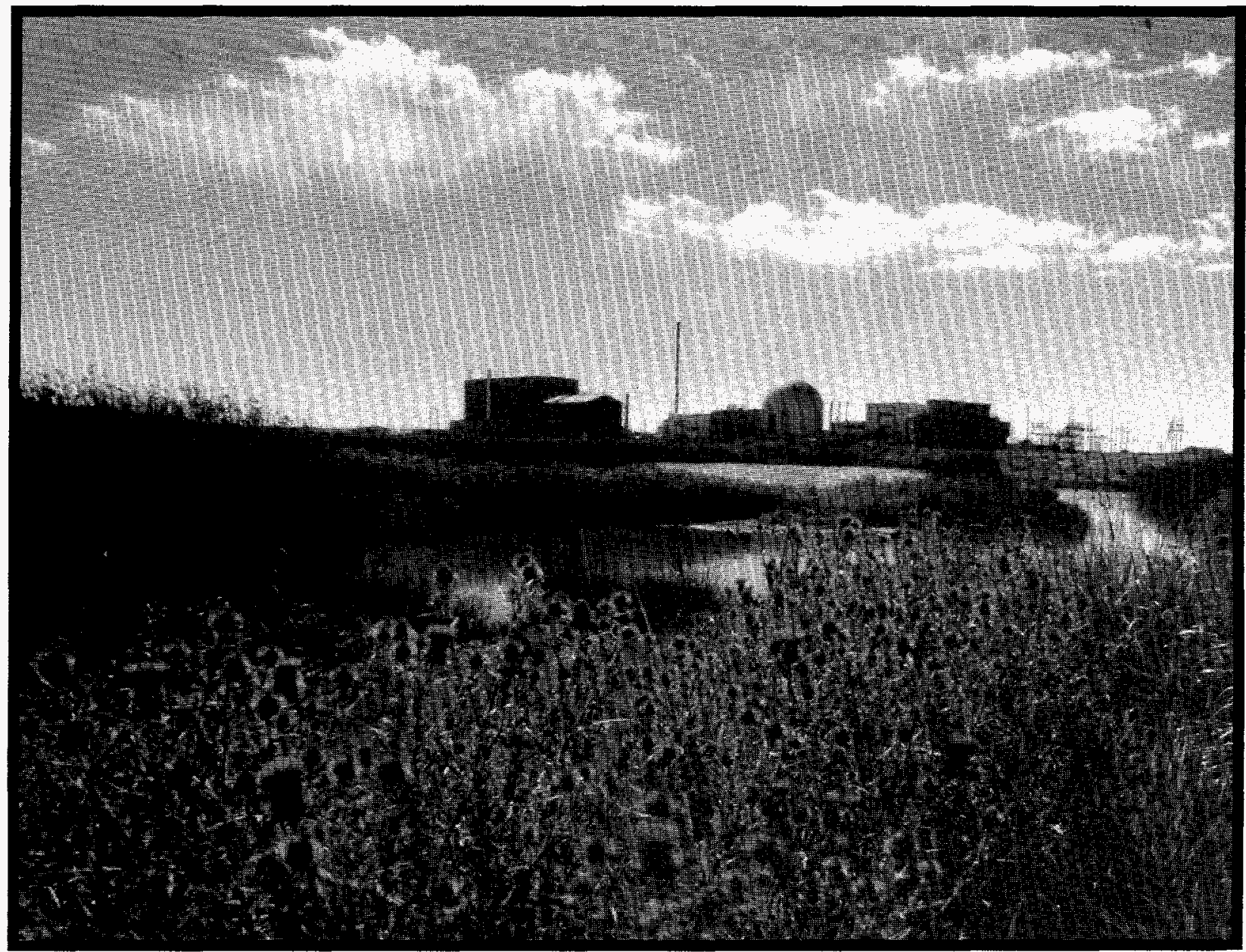

This experimental breeder reactor (EBR-II) was designed to demonstrate the feasibility of using sodium-cooled fast breeders for central station power plants and to establish technology for on-site fuel reprocessing. 



\section{Appendix D}

\section{World Nuclear Generating Units In the Construction Pipeline as of December 31, 1993}

Table D1. Roster of Nuclear Units in the Construction Pipeline as of December 31, 1993

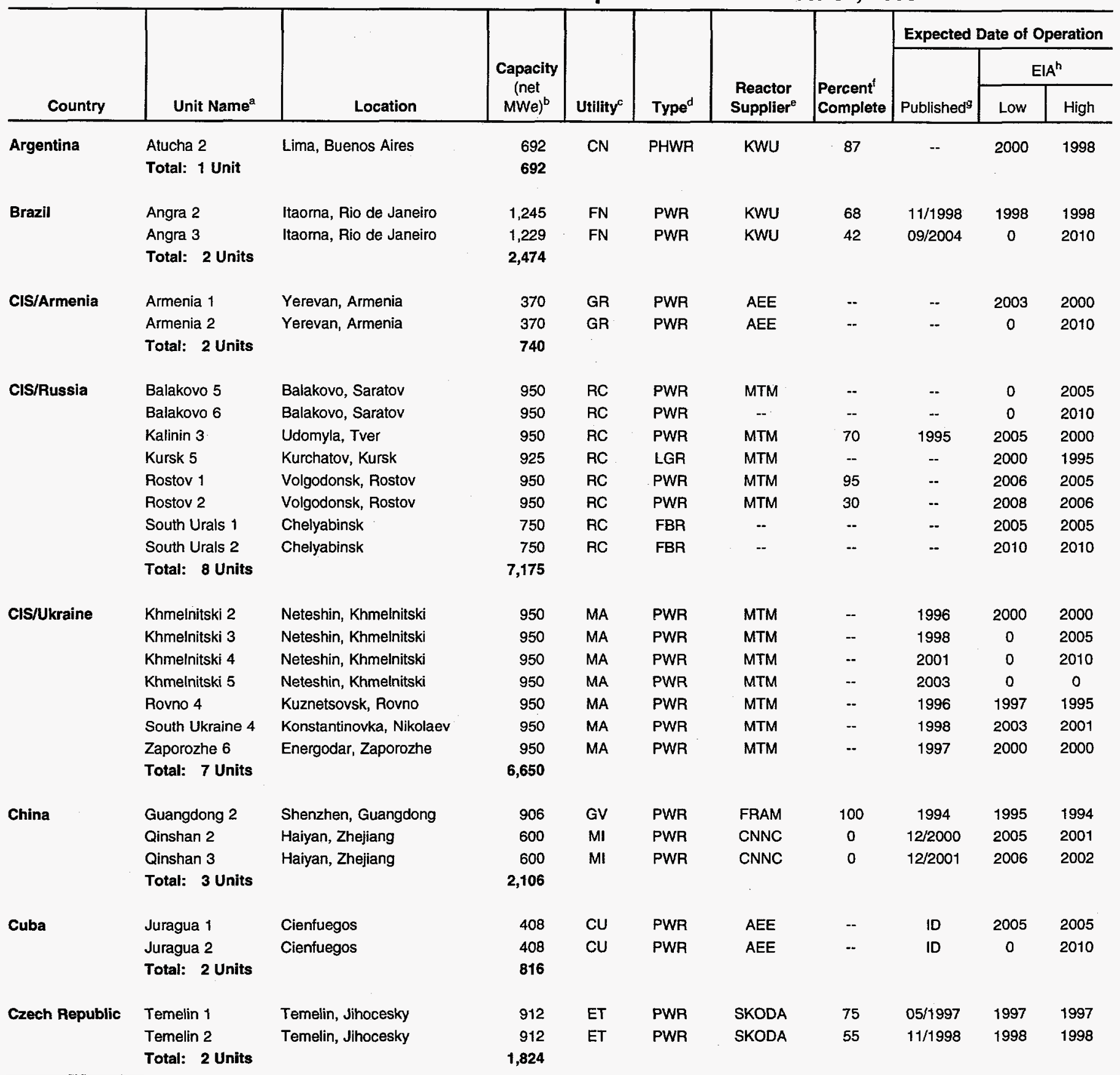

See footnotes at end of table. 
Table D1. Roster of Nuclear Units in the Construction Pipeline as of December 31, 1993 (Continued)

\begin{tabular}{|c|c|c|c|c|c|c|c|c|c|c|}
\hline \multirow[b]{2}{*}{ Country } & \multirow[b]{2}{*}{ Unit Name $^{a}$} & \multirow[b]{2}{*}{ Location } & \multirow{2}{*}{$\begin{array}{c}\text { Capacity } \\
\text { (net } \\
M W e)^{b}\end{array}$} & \multirow[b]{2}{*}{ Utility $^{c}$} & \multirow[b]{2}{*}{ Type $^{\text {d }}$} & \multirow{2}{*}{$\begin{array}{l}\text { Reactor } \\
\text { Supplier }^{\mathrm{e}}\end{array}$} & \multirow{2}{*}{$\begin{array}{l}\text { Percent } \\
\text { Complete }\end{array}$} & \multicolumn{3}{|c|}{ Expected Date of Operation } \\
\hline & & & & & & & & Published $^{9}$ & Low & High \\
\hline \multirow[t]{7}{*}{ France } & Chooz B1 & Chooz, Ardennes & 1,455 & $\mathrm{EF}$ & PWR & FRAM & 90 & $02 / 1996$ & 1996 & 1995 \\
\hline & Chooz B2 & Chooz, Ardennes & 1,455 & $E F$ & PWR & FRAM & 75 & $07 / 1996$ & 2000 & 1997 \\
\hline & Civaux 1 & Civaux, Vienne & 1,455 & $\mathrm{EF}$ & PWR & FRAM & 30 & $04 / 1997$ & 2000 & 1998 \\
\hline & Le Carnet 2 & Le Carnet & 1,455 & EF & PWR & FRAM & 0 & -- & 0 & 2010 \\
\hline & Penley 3 & St. Martin-en, Seine-Maritime & 1,455 & EF & PWR & FRAM & 0 & 2002 & 20124 & 2001 \\
\hline & Penley 4 & St. Martin-en, Seine-Maritime & 1,390 & $\mathrm{EF}$ & PWR & FRAM & 0 &.- & 2005 & 2002 \\
\hline & Total: 8 Units & & 11,570 & & & & & & & \\
\hline \multirow[t]{5}{*}{ India } & Kaiga 1 & Kaiga, Karnataka & 202 & NP & PHWR & NPCIL & 40 & $12 / 1996$ & 20100 & 1998 \\
\hline & Rajasthan 4 & Kota, Rajasthan & 202 & NP & PHWR & NPCIL & 31 & $11 / 1997$ & 2003 & 1999 \\
\hline & Tarapur 3 & Tarapur, Maharashtra & 470 & NP & PHWR & 0 & -- & $08 / 2000$ & 2009 & 2005 \\
\hline & Tarapur 4 & Tarapur, Maharashtra & 470 & NP & PHWR & 0 & -. & $05 / 2001$ & 2010 & 2005 \\
\hline & Total: 8 Units & & 2,170 & & & & & & & \\
\hline \multirow[t]{14}{*}{ Japan } & Ashihama 1 & Ashihama & 1,283 & $\mathrm{CB}$ & ABWR & -- & 0 & 2003 & 2005 & 2003 \\
\hline & Ashihama 2 & Ashihama & 1,283 & $\mathrm{CB}$ & ABWR & $-\cdot$ & 0 & 2004 & 20138 & 2005 \\
\hline & Ashihama 3 & Ashihama & 1,283 & $\mathrm{CB}$ & ABVIR & -- & 0 & -- & 2010 & 2009 \\
\hline & Genkai 4 & Genkai, Saga & 1,127 & KY & PWR & MHI & 47 & $07 / 1997$ & 2000 & 1998 \\
\hline & Hamaoka 5 & Hamaoka-cho, Shizuoka & 1,092 & $\mathrm{CB}$ & ABWR & -- & 0 & 2008 & 0 & 2010 \\
\hline & Higashidori 1 & Higashidori & 1,067 & TC & BWR & -. & 0 & 2004 & 20109 & 2005 \\
\hline & Higashidori 2 & Higashidori & 1,067 & TC & BWR & -- & 0 & 2005 & 2010 & 2005 \\
\hline & Maki 2 & Maki, Niigata & 1,067 & TC & BWR & -- & 0 & - & 0 & 0 \\
\hline & Monju & Tsuruga, Fukui & 246 & PF & FBR & $\mathrm{MHI}$ & 99 & 1995 & 1995 & 1995 \\
\hline & Onagawa 2 & Onagawa, Miyagi & 796 & TC & BWR & TOS & 89 & $07 / 1995$ & 1995 & 1995 \\
\hline & Oura 1 & Oura & 1,296 & KA & APWR & -- & 0 & 2010 & 0 & 2010 \\
\hline & Oura 2 & Oura & 1,296 & KA & APWR & - & 0 & 2010 & 0 & 2010 \\
\hline & Shika 2 & Shika-machi, Ishikawa & 796 & $\mathrm{HU}$ & ABWR & -- & 0 & 2006 & 2010 & 2010 \\
\hline & Total: 19 Units & & 20,105 & & & & & & & \\
\hline \multirow[t]{3}{*}{ Korea, North } & Nyongbyon & Nyongbyon, Korea & 50 & - & HWR & -- & -- & 1996 & 1996 & 1996 \\
\hline & Taechon 1 & Taechon, Korea & 200 & -- & HWR & -- & - & 1998 & 0 & 2001 \\
\hline & Total: 2 Units & & 250 & & & & & & & \\
\hline \multirow[t]{8}{*}{ Korea, South } & Ulchin 3 & Ulchin, Kyongbuk & 960 & KR & PWR & $\mathrm{KHIC} / \mathrm{KAE} / \mathrm{C}-\mathrm{E}$ & 18 & $06 / 1998$ & 2001 & 2000 \\
\hline & Uichin 4 & Ulchin, Kyongbuk & 960 & KR & PW/R & KHIC/KAE/C-E & 18 & 06/1999 & 2002 & 2000 \\
\hline & Wolsong 2 & Kyongju, Kyongbuk & 650 & KR & PHWR & AECL/KHIC & 22 & $06 / 1997$ & 2003 & 2000 \\
\hline & Wolsong 3 & Kyongju, Kyongbuk & 650 & $\mathrm{KR}$ & PHWR & AECL/KHIC & 0 & $06 / 1998$ & 2004 & 2001 \\
\hline & Wolsong 4 & Kyongju, Kyongbuk & 650 & $\mathrm{KR}$ & PHWR & AECL/KHIC & 0 & $06 / 1999$ & 2004 & 2001 \\
\hline & Yonggwang 3 & Yonggwang, Chonnam & 950 & KR & PW/R & $\mathrm{KHIC} / \mathrm{KAE} / \mathrm{C}-\mathrm{E}$ & 72 & $03 / 1995$ & 1995 & 1995 \\
\hline & Yonggwang 4 & Yonggwang, Chonnam & 950 & KR & PWR & KHIC/KAE/C-E & 72 & $03 / 1996$ & 1997 & 1996 \\
\hline & Total: 7 Units & & 5,770 & & & & & & & \\
\hline
\end{tabular}

See footnotes at end of table. 
Table D1. Roster of Nuclear Units in the Construction Pipeline as of December 31, 1993 (Continued)

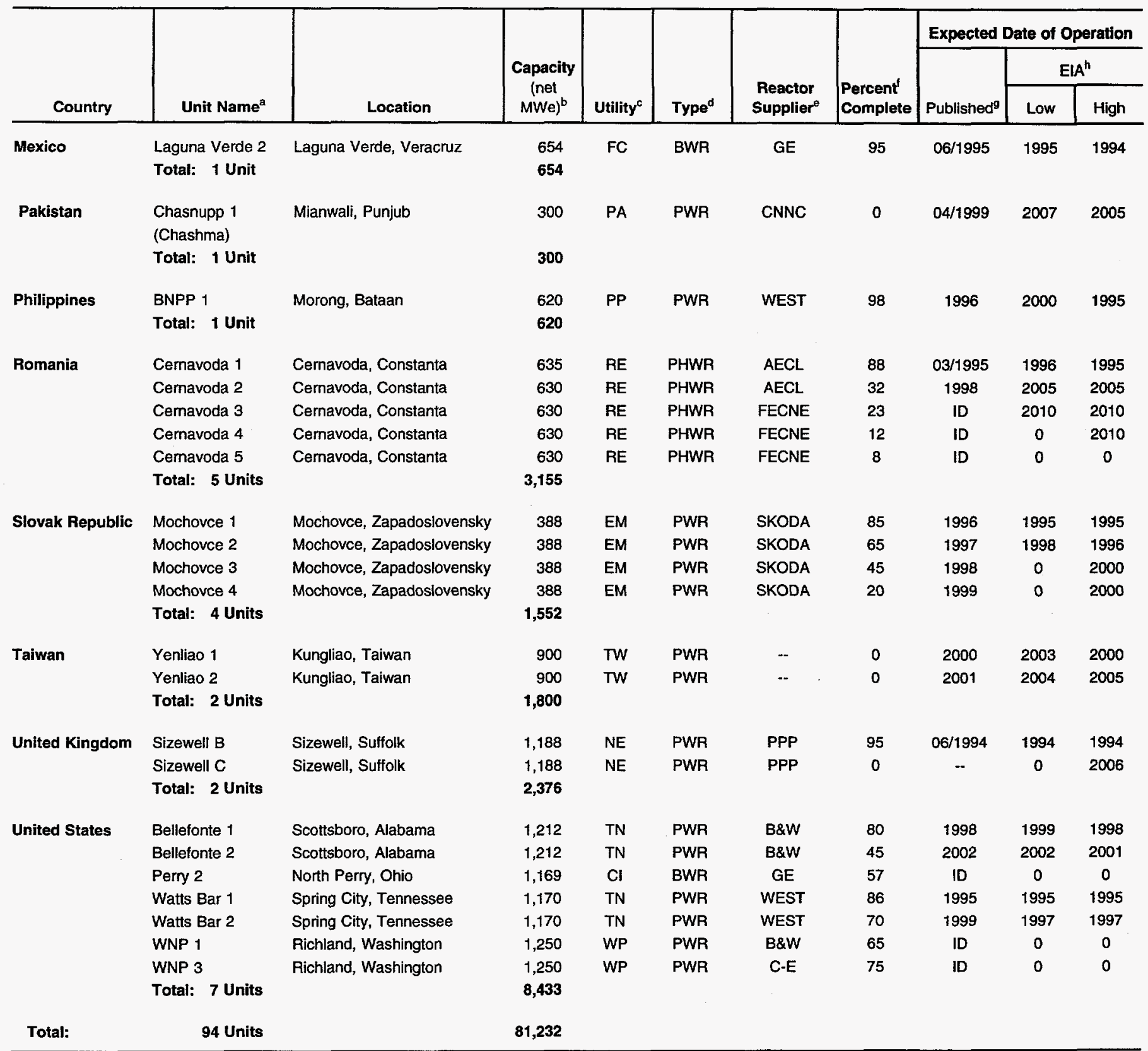

aThe Energy Information Administration's review of the latest data sources may have resulted in revisions of names, capacities, and operation dates. For the United States, revisions are based on the Form-860 "Annual Electric Generator Report."

$\mathrm{MWe}=$ Megawatts-electric.

'See Table C2 for key to abbreviations of utility names.

${ }^{d}$ Reactor Types: APWR, advanced pressurized light-water-moderated and cooled reactor; ABWR advanced boiling light-water-cooled and moderated reactor; BWR, boiling light-water-cooled and moderated reactor; FBR, fast breeder reactor; LGR, light-water-cooled, graphite-moderated reactor; PHWR, pressurized heavywater-moderated and cooled reactor; PWR, pressurized light-water-moderated and cooled reactor.

'See Table C3 for key to abbreviations of reactor supplier names.

'Percent complete is an estimate of how close the nuclear unit is to completion. A dash (-) indicates that an approximation of the units' completion is unknown. ${ }^{9}$ Published date is the estimated date of commercial operation.

hEIA projections in the Low and High Cases refer to when a nuclear unit is estimated to become operable. A dash (--) incicates that the estimated year of operability is beyond the year 2010. ID = Indefinitely deferred.

Note: Totals may not equal sum of components due to independent rounding.

Sources: International Atomic Energy Agency, Nuclear Power Reactors in the World (Vienna, Austria, April 1994); Nuclear News, "World List of Nuclear Power Plants" (March 1994), pp. 43-62. NUKEM, "World Nuclear Capacity" (January 1994), pp. 16-41; Form ElA-860 "Annual Electric Generator Report." 

Appendix E

\section{Long-Term Projections of Capacity, Generation, and Spent Fuel in the United States, 1994 Through 2040}

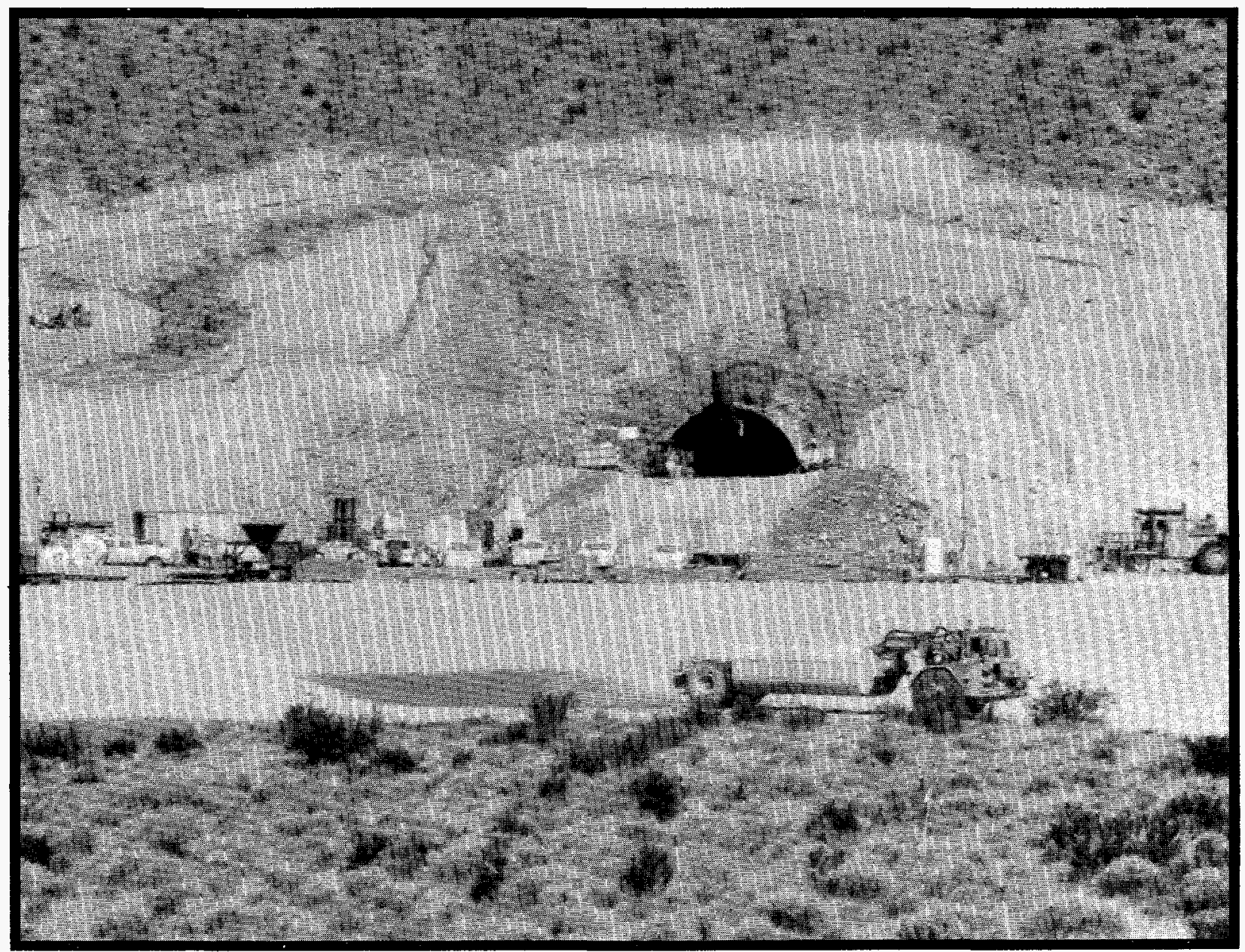

Yucca Mountain, located 100 miles northwest of Las Vegas, is being studies to determine the suitability for a commercial high-level radioactive waste repository. 



\section{Long-Term Projections of Capacity, Generation, and Spent Fuel in the United States, 1994 Through 2040}

This appendix contains long-term projections of nuclear capacity, nuclear electricity generation, and spent fuel discharges in the United States through 2040. There are three scenarios, a Low, Mid, and High Case.

For the Low Case, there are no new orders for reactors in the United States, and the reactors currently in operation continue for the term of their operating licenses. Four units under construction are projected to start operation between 1995 and 2002 (see Appendix D). ${ }^{126}$

For the Mid Case, there are also no new orders for reactors in the United States. Additionally, 55 of the 109 reactors in operation at the end of 1993 (about 50 percent) will extend their operating licenses for 20 years beyond the 40-year term. Also, Diablo Canyon 1 and 2 will obtain a redefinition of their operating licenses to extend 40 years beyond the issuance of their operating license instead of 40 years beyond the date when their construction license was issued. Finally, the start dates for Bellefonte 1 and 2 will be 1 year sooner than the dates assumed in the Low Case.

Of the three scenarios, the High Case is the only scenario where new reactors, besides those currently under construction, will be built. The High Case uses the same assumptions used in the Mid Case for reactors in operation and under construction. In addition, projections of nuclear capacity past 2010 for the High Case, are based on the WINES model (see Appendix B for a brief discussion of the WINES model). No projections past 2030 were made for the High Case because parameters, such as aggregate energy demand in the United States and other macro economic variables, needed for the WINES model were not available.

Nuclear capacity in the United States is projected to be between 6 gigawatts electric (GWe) and 113 GWe by
2030 (Table E1 and Figure E1). The Mid Case projects nuclear capacity to be about $56 \mathrm{GWe}$ in 2030 . The wide range in capacity reflects the uncertainty of the role nuclear power will play in the future. In order for an upsurge in nuclear power to occur, as suggested in the High Case, major events must take place. Resolution of the nuclear waste problem, reduction in nuclear operating and maintenance costs, and improvement in the public's perception of nuclear power are among the most important things that must occur. At the other extreme of the range, the Low Case suggests that commercial nuclear power, with the exception of a few units, will be eliminated from the mix of electrical power plants by 2030 . The truth probably lies between these two extremes. The Mid Case does not represent, however, the most probable outcome of these projections. It represents a scenario with declining capacity through 2040, differing from the Low Case by the rate of decline.

Projections of nuclear electricity generation through 2030 are between 41 net terawatthours (TWh) and 734 net TWh (Table E2). The industry-wide annual capacity factor used to calculate electricity generation is 70 percent in 1994, increasing to about 75 percent through 2030. Improvements in capacity factors are due primarily from older, poor performing plants retiring from service. The newer plants (i.e., those coming online in the 1980's) have better performance records than older plants, on the average, and this difference in performance is assumed to continue over the years.

Projections of spent fuel permanently discharged from nuclear power units range between 86 and 101 thousand metric tons of uranium (MTU) by 2030 (Figure E2). As of the end of 1993, there were 28.0 thousand MTU of spent fuel discharges.

\footnotetext{
${ }^{126}$ The Low Case through 2010 contains the same nuclear capacity projections found in the Energy Information Administration's Annual Energy Outlook (AEO) 1994 (January 1994). The AEO does not contain projections of nuclear capacity past 2010.
} 
Table E1. Projections of U.S. Nuclear Capacity, 1994-2040

(Gigawatts Electric)

\begin{tabular}{|c|c|c|c|c|}
\hline & Year & Low Case & Mid Case & High Case \\
\hline 1994 & $\ldots \ldots \ldots$ & 99.0 & 99.0 & 99.0 \\
\hline 1995 & $\ldots \ldots \ldots$ & 100.2 & 100.2 & 100.2 \\
\hline 1996 & $\ldots \ldots \ldots$ & 100.2 & 100.2 & 100.2 \\
\hline 1997 & $\ldots \ldots \ldots$ & 101.4 & 101.4 & 101.4 \\
\hline 1998 & $\ldots \ldots \ldots$ & 101.4 & 102.6 & 102.6 \\
\hline 1999 & $\ldots \ldots \ldots$ & 102.6 & 102.6 & 102.6 \\
\hline 2000 & $\ldots \ldots \ldots$ & 102.5 & 102.5 & 102.5 \\
\hline 2001 & $\ldots \ldots \ldots$ & 102.5 & 103.7 & 103.7 \\
\hline 2002 & $\ldots \ldots \ldots$ & 103.7 & 103.7 & 103.7 \\
\hline 2003 & $\ldots \ldots \ldots$ & 103.7 & 103.7 & 103.7 \\
\hline 2004 & $\ldots \ldots \ldots$ & 103.7 & 103.7 & 103.7 \\
\hline 2005 & $\ldots \ldots \ldots$ & 103.7 & 103.7 & 103.7 \\
\hline 2006 & $\ldots \ldots \ldots$ & 103.0 & 103.7 & 103.7 \\
\hline 2007 & $\ldots \ldots \ldots$ & 100.3 & 101.1 & 101.1 \\
\hline 2008 & $\ldots \ldots \ldots$ & 95.8 & 97.7 & 97.7 \\
\hline 2009 & $\ldots \ldots \ldots$ & 94.1 & 96.0 & 96.0 \\
\hline 2010 & $\ldots \ldots \ldots$ & 90.7 & 94.7 & 94.7 \\
\hline 2011 & $\ldots \ldots \ldots$ & 89.9 & 94.7 & 94.7 \\
\hline 2012 & $\ldots \ldots \ldots$ & 86.4 & 94.0 & 94.0 \\
\hline 2013 & $\ldots \ldots \ldots$ & 76.2 & 87.8 & 94.3 \\
\hline 2014 & $\ldots \ldots \ldots$ & 66.8 & 81.4 & 94.6 \\
\hline 2015 & $\ldots \ldots \ldots$ & 64.9 & 79.6 & 99.3 \\
\hline 2016 & $\ldots \ldots \ldots$ & 58.7 & 75.3 & 97.0 \\
\hline 2017 & $\ldots \ldots \ldots$ & 55.9 & 75.3 & 99.1 \\
\hline 2018 & $\ldots \ldots \ldots$ & 53.4 & 75.3 & 101.1 \\
\hline 2019 & $\ldots \ldots \ldots$ & 53.4 & 75.3 & 103.2 \\
\hline 2020 & $\ldots \ldots \ldots$ & 50.3 & 73.0 & 103.0 \\
\hline 2021 & $\ldots \ldots \ldots$ & 47.2 & 71.9 & 105.1 \\
\hline 2022 & $\ldots \ldots \ldots$ & 43.1 & 71.9 & 108.2 \\
\hline 2023 & $\ldots \ldots \ldots$ & 39.0 & 70.8 & 110.2 \\
\hline 2024 & $\ldots \ldots \ldots$ & 31.2 & 66.4 & 108.9 \\
\hline 2025 & $\ldots \ldots \ldots$ & 25.6 & 61.9 & 107.7 \\
\hline 2026 & $\ldots \ldots \ldots$ & 16.1 & 58.9 & 106.9 \\
\hline 2027 & $\ldots \ldots \ldots$ & 10.5 & 56.8 & 107.1 \\
\hline 2028 & $\ldots \ldots \ldots$ & 9.3 & 56.8 & 109.3 \\
\hline 2029 & $\ldots \ldots \ldots$ & 7.1 & 56.0 & 110.8 \\
\hline 2030 & $\ldots \ldots \ldots$ & 5.9 & 55.6 & 112.6 \\
\hline 2031 & $\ldots \ldots \ldots$ & 5.9 & 54.2 & -- \\
\hline 2032 & $\ldots \ldots \ldots$ & 5.9 & 51.9 & - \\
\hline 2033 & $\ldots \ldots \ldots$ & 4.8 & 46.8 & -- \\
\hline 2034 & $\ldots \ldots \ldots$ & 4.8 & 43.2 & -- \\
\hline 2035 & $\ldots \ldots \ldots$ & 3.6 & 42.0 & -- \\
\hline 2036 & $\ldots \ldots \ldots$ & 3.6 & 40.1 & -. \\
\hline 2037 & $\ldots \ldots \ldots$ & 2.4 & 36.2 & -- \\
\hline 2038 & $\ldots \ldots \ldots$ & 2.4 & 32.4 & -. \\
\hline 2039 & $\ldots \ldots \ldots$ & 1.2 & 32.4 & - \\
\hline 2040 & $\ldots \ldots \ldots$ & 1.2 & 31.6 & - \\
\hline
\end{tabular}

$--=$ No WINES model projections were made past 2030.

Source: Low and Mid Cases, Energy Information Administration, Office of Coal, Nuclear, Electric, and Alternate Fuels, International Nuclear Model, File INM94.WK3. High Case, Energy Information Administration, Office of Integrated Analysis and Forecasting, WINES Model.
Table E2. Projections of U.S. Nuclear Electricity Generation, 1994-2040 (Net Terawatthours)

\begin{tabular}{|c|c|c|c|c|}
\hline & Year & Low Case & Mid Case & High Case \\
\hline 1994 & $\ldots \ldots \ldots \ldots$ & 611 & 611 & 611 \\
\hline 1995 & $\ldots \ldots \ldots \ldots$ & 618 & 618 & 618 \\
\hline 1996 & $\ldots \ldots \ldots \ldots$ & 619 & 619 & 619 \\
\hline 1997 & $\ldots \ldots \ldots \ldots$ & 643 & 643 & 643 \\
\hline 1998 & $\ldots \ldots \ldots \ldots$ & 644 & 650 & 650 \\
\hline 1999 & $\ldots \ldots \ldots \ldots$ & 651 & 652 & 652 \\
\hline 2000 & $\ldots \ldots \ldots \ldots$ & 652 & 652 & 652 \\
\hline 2001 & $\ldots \ldots \ldots \ldots$ & 652 & 660 & 660 \\
\hline 2002 & $\ldots \ldots \ldots \ldots$ & 660 & 660 & 660 \\
\hline 2003 & $\ldots \ldots \ldots \ldots$ & 660 & 660 & 660 \\
\hline 2004 & $\ldots \ldots \ldots \ldots$ & 660 & 660 & 660 \\
\hline 2005 & $\ldots \ldots \ldots \ldots$ & 660 & 660 & 660 \\
\hline 2006 & $\ldots \ldots \ldots \ldots$ & 656 & 660 & 660 \\
\hline 2007 & $\ldots \ldots \ldots \ldots$ & 649 & 653 & 653 \\
\hline 2008 & $\ldots \ldots \ldots \ldots$ & 633 & 637 & 637 \\
\hline 2009 & $\ldots \ldots \ldots \ldots$ & 607 & 618 & 618 \\
\hline 2010 & $\ldots \ldots \ldots \ldots$ & 587 & 605 & 605 \\
\hline 2011 & $\ldots \ldots \ldots \ldots$ & 576 & 605 & 605 \\
\hline 2012 & $\ldots \ldots \ldots \ldots$ & 568 & 604 & 604 \\
\hline 2013 & $\ldots \ldots \ldots \ldots$ & 530 & 594 & 611 \\
\hline 2014 & $\ldots \ldots \ldots$ & 466 & 551 & 603 \\
\hline 2015 & $\ldots \ldots \ldots \ldots$ & 426 & 523 & 616 \\
\hline 2016 & $\ldots \ldots \ldots \ldots$ & 406 & 510 & 634 \\
\hline 2017 & $\ldots \ldots \ldots \ldots$ & 377 & 492 & 637 \\
\hline 2018 & $\ldots \ldots \ldots \ldots$ & 360 & 492 & 651 \\
\hline 2019 & $\ldots \ldots \ldots \ldots$ & 350 & 492 & 664 \\
\hline 2020 & $\ldots \ldots \ldots \ldots$ & 342 & 487 & 673 \\
\hline 2021 & $\ldots \ldots \ldots \ldots$ & 321 & 478 & 680 \\
\hline 2022 & $\ldots \ldots \ldots \ldots$ & 306 & 473 & 694 \\
\hline 2023 & $\ldots \ldots \ldots \ldots$ & 266 & 469 & 711 \\
\hline 2024 & $\ldots \ldots \ldots \ldots$ & 225 & 454 & 716 \\
\hline 2025 & $\ldots \ldots \ldots \ldots$ & 183 & 422 & 705 \\
\hline 2026 & $\ldots \ldots \ldots \ldots$ & 126 & 400 & 702 \\
\hline 2027 & $\ldots \ldots \ldots \ldots$ & 87 & 388 & 705 \\
\hline 2028 & $\ldots \ldots \ldots \ldots$ & 64 & 376 & 709 \\
\hline 2029 & $\ldots \ldots \ldots \ldots$ & 52 & 373 & 719 \\
\hline 2030 & $\ldots \ldots \ldots \ldots$ & 41 & 372 & 734 \\
\hline 2031 & $\ldots \ldots \ldots \ldots$ & 38 & 362 & -- \\
\hline 2032 & $\ldots \ldots \ldots \ldots$ & 38 & 358 & -- \\
\hline 2033 & $\ldots \ldots \ldots \ldots$ & 31 & 323 & - \\
\hline 2034 & $\ldots \ldots \ldots \ldots$ & 31 & 299 & - \\
\hline 2035 & $\ldots \ldots \ldots \ldots$ & 23 & 279 & - \\
\hline 2036 & $\ldots \ldots \ldots \ldots$ & 23 & 272 & - \\
\hline 2037 & $\ldots \ldots \ldots \ldots$ & 16 & 253 & $\cdots$ \\
\hline 2038 & $\ldots \ldots \ldots \ldots$ & 16 & 228 & - \\
\hline 2039 & $\ldots \ldots \ldots \ldots$ & 8 & 218 & $\ldots$ \\
\hline 2040 & $\ldots \ldots \ldots \ldots$ & 8 & 216 & -- \\
\hline
\end{tabular}

$--=$ No WINES model projections were made past 2030.

Source: Low and Mid Cases, Energy Information Administration, Office of Coal, Nuclear, Electric, and Alternate Fuels, International Nuclear Model, File INM94.WK3. High Case, Energy Information Administration, Office of Integrated Analysis and Forecasting, WINES Model. 
Figure E1. Projections of U.S. Nuclear Capacity, 1994-2030

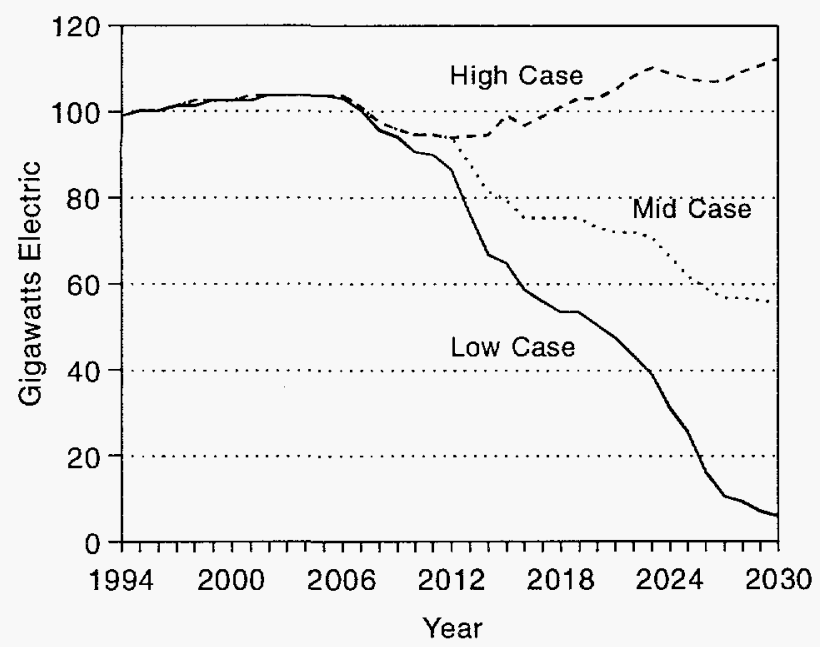

Sources: Energy Information Administration, Low and Mid Cases, Office of Coal, Nuclear, Electric, and Alternate Fuels, International Nuclear Model, File INM94.WK3. High Case, Office of Integrated Analysis and Forecasting, WINES Model.

Figure E2. Projections of Cumulative U.S. Spent Fuel Discharges, 1994-2030

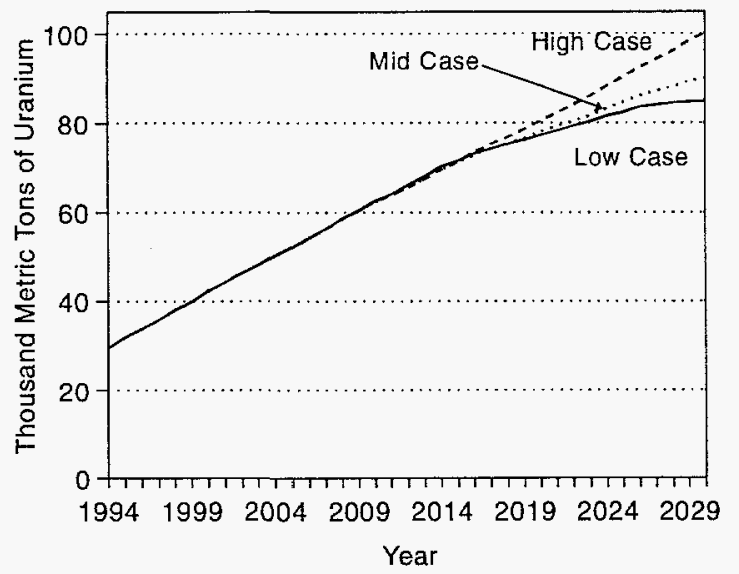

Sources: Energy Information Administration, Low and Mid Cases, Office of Coal, Nuclear, Electric, and Alternate Fuels, International Nuclear Model, File INM94.WK3. High Case, Office of Integrated Analysis and Forecasting, WINES Model.
Table E3. Projections of U.S. Cumulative Spent Fuel Discharges Through 2040 (Thousand Metric Tons of Uranium)

\begin{tabular}{|c|c|c|c|c|}
\hline & Year & Low Case & Mid Case & High Case \\
\hline Prior 1 & $1994 \ldots \ldots$ & 28.0 & 28.0 & 28.0 \\
\hline $1994^{a}$ & $\ldots \ldots \ldots$ & 29.9 & 29.9 & 29.9 \\
\hline 1995 & $\ldots \ldots \ldots$ & 32.3 & 32.3 & 32.3 \\
\hline 1996 & $\ldots \ldots \ldots$ & 34.1 & 34.1 & 34.1 \\
\hline 1997 & $\ldots \ldots \ldots \ldots$ & 36.1 & 36.1 & 36.1 \\
\hline 1998 & $\ldots \ldots \ldots$ & 38.1 & 38.1 & 38.1 \\
\hline 1999 & $\ldots \ldots \ldots \ldots$ & 40.0 & 40.1 & 40.1 \\
\hline 2000 & $\ldots \ldots \ldots$ & 42.2 & 42.3 & 42.3 \\
\hline 2001 & $\ldots \ldots \ldots \ldots$ & 44.2 & 44.2 & 44.2 \\
\hline 2002 & $\ldots \ldots \ldots$ & 45.2 & 46.2 & 46.2 \\
\hline 2003 & $\ldots \ldots \ldots$ & 48.2 & 48.3 & 48.3 \\
\hline 2004 & $\ldots \ldots \ldots \ldots$ & 50.4 & 50.4 & 50.4 \\
\hline 2005 & $\ldots \ldots \ldots \ldots$ & 51.9 & 52.0 & 52.0 \\
\hline 2006 & $\ldots \ldots \ldots$ & 54.4 & 54.3 & 54.3 \\
\hline 2007 & $\ldots \ldots \ldots$ & 56.3 & 56.3 & 56.3 \\
\hline 2008 & $\ldots \ldots \ldots$ & 58.6 & 58.5 & 58.5 \\
\hline 2009 & $\ldots \ldots \ldots$ & 60.6 & 60.6 & 60.6 \\
\hline 2010 & $\ldots \ldots \ldots$ & 62.5 & 62.3 & 62.3 \\
\hline 2011 & $\ldots \ldots \ldots$ & 64.3 & 64.1 & 64.1 \\
\hline 2012 & $\ldots \ldots \ldots \ldots$ & 66.1 & 65.7 & 65.7 \\
\hline 2013 & $\ldots \ldots \ldots$ & 68.4 & 67.8 & 67.8 \\
\hline 2014 & $\ldots \ldots \ldots \ldots$ & 70.5 & 69.9 & 69.9 \\
\hline 2015 & $\ldots \ldots \ldots$ & 71.9 & 71.5 & 71.7 \\
\hline 2016 & $\ldots \ldots \ldots$ & 73.4 & 73.1 & 73.7 \\
\hline 2017 & $\ldots \ldots \ldots$ & 74.7 & 74.6 & 75.7 \\
\hline 2018 & $\ldots \ldots \ldots$ & 75.8 & 75.6 & 77.2 \\
\hline 2019 & $\ldots \ldots \ldots$ & 76.7 & 77.1 & 79.0 \\
\hline 2020 & $\ldots \ldots \ldots$ & 77.7 & 78.5 & 80.9 \\
\hline 2021 & $\ldots \ldots \ldots$ & 78.8 & 79.6 & $82: 6$ \\
\hline 2022 & $\ldots \ldots \ldots$ & 80.2 & 81.2 & 84.8 \\
\hline 2023 & $\ldots \ldots \ldots$ & 81.0 & 82.2 & 86.5 \\
\hline 2024 & $\ldots \ldots \ldots \ldots$ & 82.3 & 83.8 & 88.8 \\
\hline 2025 & $\ldots \ldots \ldots$ & 83.2 & 85.5 & 91.2 \\
\hline 2026 & $\ldots \ldots \ldots$ & 84.3 & 86.7 & 93.2 \\
\hline 2027 & $\ldots \ldots \ldots$ & 84.9 & 87.9 & 95.2 \\
\hline 2028 & $\ldots \ldots \ldots$ & 85.1 & 88.9 & 97.0 \\
\hline 2029 & $\ldots \ldots \ldots \ldots$ & 85.4 & 89.9 & 99.1 \\
\hline 2030 & $\ldots \ldots \ldots \ldots$ & 85.6 & 90.9 & 100.9 \\
\hline 2031 & $\ldots \ldots \ldots$ & 85.7 & 92.0 & - \\
\hline 2032 & $\ldots \ldots \ldots$ & 85.8 & 93.2 & - \\
\hline 2033 & $\ldots \ldots \ldots$ & 85.9 & 94.4 & -- \\
\hline 2034 & $\ldots \ldots \ldots$ & 86.0 & 95.5 & -- \\
\hline 2035 & $\ldots \ldots \ldots$ & 86.1 & 96.4 & -- \\
\hline 2036 & $\ldots \ldots \ldots$ & 86.2 & 97.3 & -- \\
\hline 2037 & $\ldots \ldots \ldots$ & 86.3 & 98.2 & -- \\
\hline 2038 & $\ldots \ldots \ldots$ & 86.3 & 99.1 & - \\
\hline 2039 & $\ldots \ldots \ldots$ & 86.4 & 99.6 & - \\
\hline 2040 & $\ldots \ldots \ldots$ & 86.5 & 100.3 & - \\
\hline
\end{tabular}

-- = No WINES model projections were made past 2030.

Source: Low and Mid Cases, Energy Information Administration, Office of Coal, Nuclear, Electric, and Alternate Fuels, International Nuclear Model, File INM94.WK3. High Case, Energy Information Administration, Office of Integrated Analysis and Forecasting, WINES Model. 

Appendix F

\section{World Nuclear Fuel Cycle Facilities That Prepare Fuel for Nuclear Power Plants}

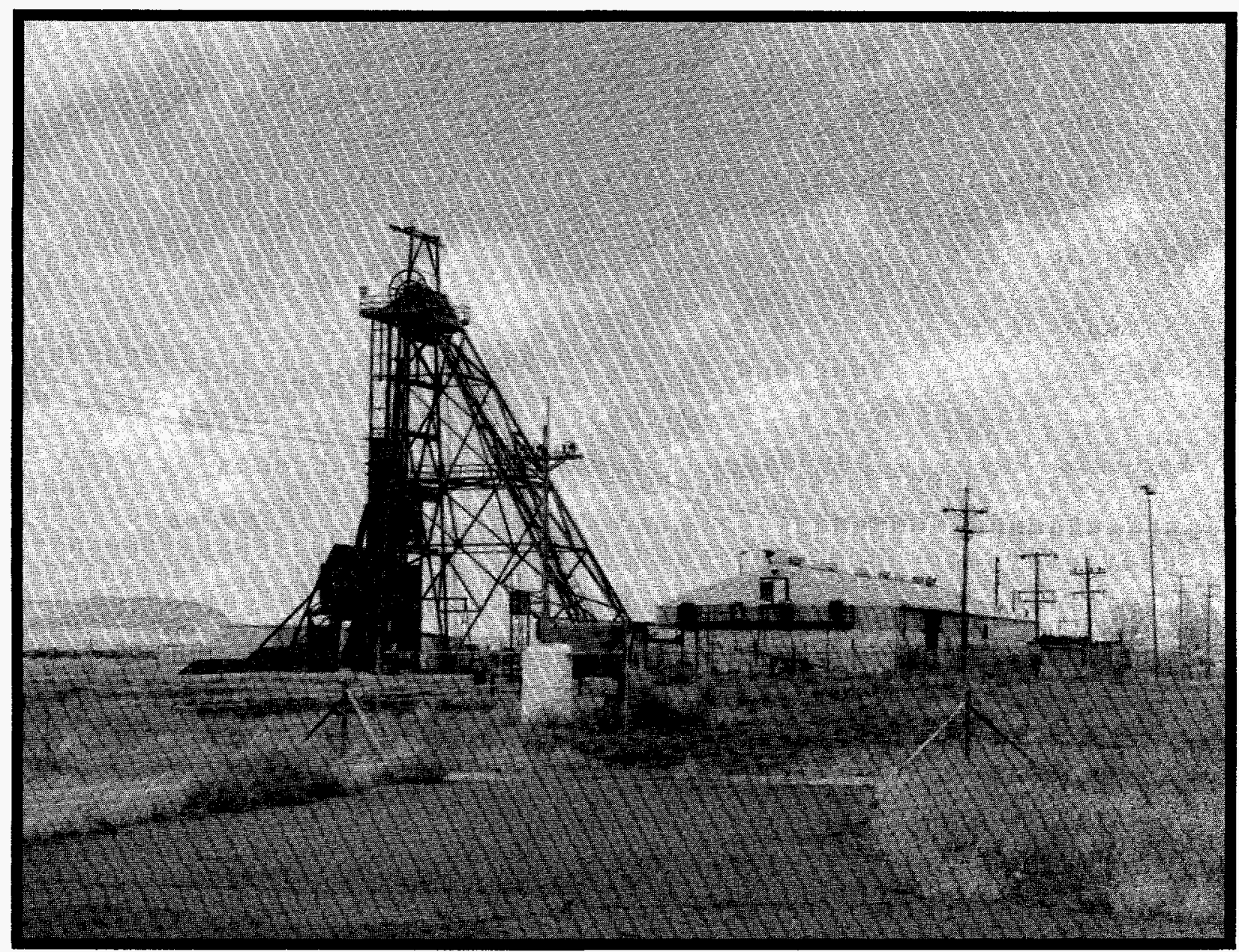

The old Homestake mine shaft located in Grants, New Mexico, was built in 1958. The mill's capacity was rated at 3,000 tons of ore per day. The mill is currently in the process of being decommissioned. 


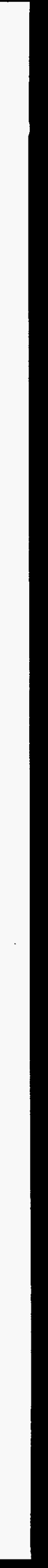




\section{Appendix F}

\section{World Nuclear Fuel Cycle Facilities That Prepare Fuel for Nuclear Power Plants}

Table F1. World Nuclear Fuel Cycle Facilities That Prepare Fuel for Nuclear Power Plants

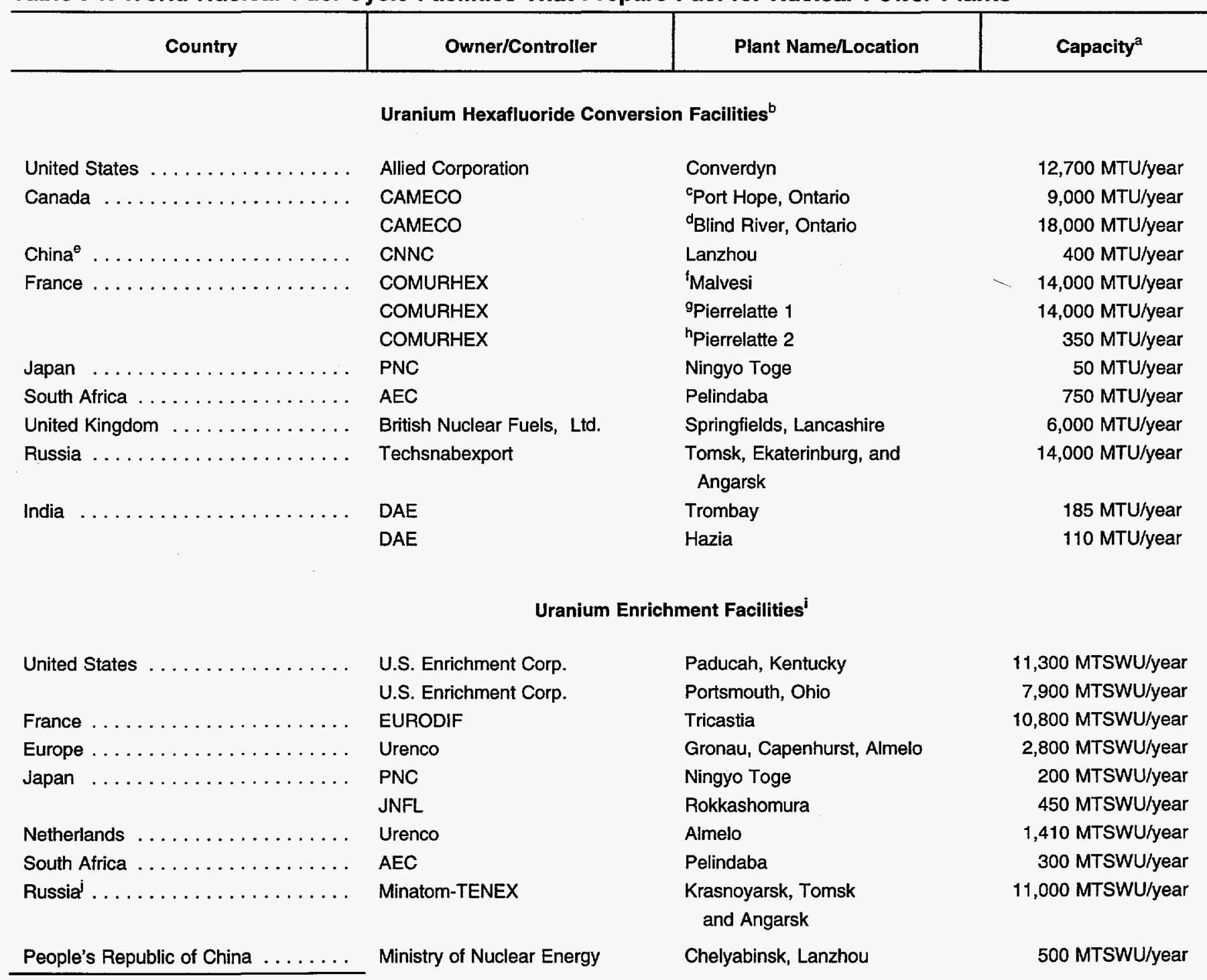

See footnotes at end of table. 
Table F1. World Nuclear Fuel Cycle Facilities That Prepare Fuel for Nuclear Power Plants (Continued)

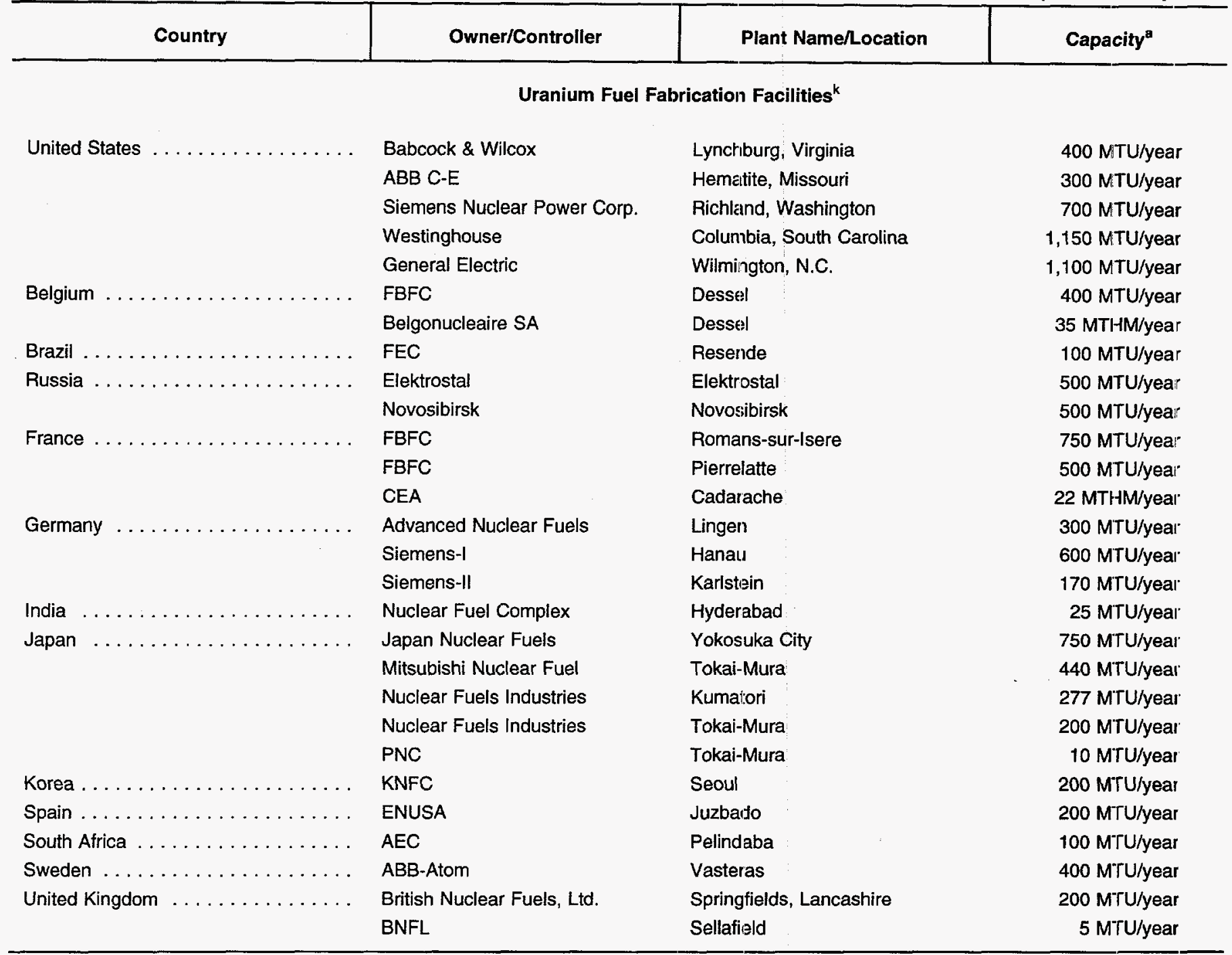

Note: This table includes the main facilities that prepare fuel for power plants. It does not include auxiliary facilities or plants that support those main facilities.

${ }^{a}$ Status as of December 1993. MTU, metric tons of uranium; MTSWU, metric tons of separative work units; MTIHM, Metric Toris Initial Heavy Metal.

'Nuclear Assurance Corporation, Fuel-Trac Reports, "UF, Status Report" (Atlanta, GA, February 1994), pp. B3:2-4.

$\mathrm{CUO}_{3}$ to $\mathrm{UF}_{6}$.

${ }^{\mathrm{d}} \mathrm{U}_{3} \mathrm{O}_{8}$ to $\mathrm{UO}_{3}$.

'NAC's estimate based on domestic fuel-cycle industry.

${ }^{\prime} \mathrm{U}_{3} \mathrm{O}_{8}$ to $\mathrm{UF}_{4}$.

$\mathrm{SUF}_{4}$ to $\mathrm{UF}_{6}$.

hConversion of reprocessed (irradiated) $\mathrm{UO}_{3}\left(\mathrm{NO}_{3}\right)_{2}$ to $\mathrm{UF}_{6}$.

'Nuclear Assurance Corporation, Fuel-Trac Reports, "Enrichment Status Report" (Atlanta, GA, February 1994), pp. B3:2-3.

'Most likely available capacity, not confirmed by Minatom.

${ }^{\mathrm{k}}$ Nuclear Assurance Corporation, Fuel-Trac Reports, "LWR Fabrication Status Report" Volume 1 (Atlanta, GA, February 1994), pp. B3:55-9. 
Appendix G

Uncertainties in the U.S. Uranium Market

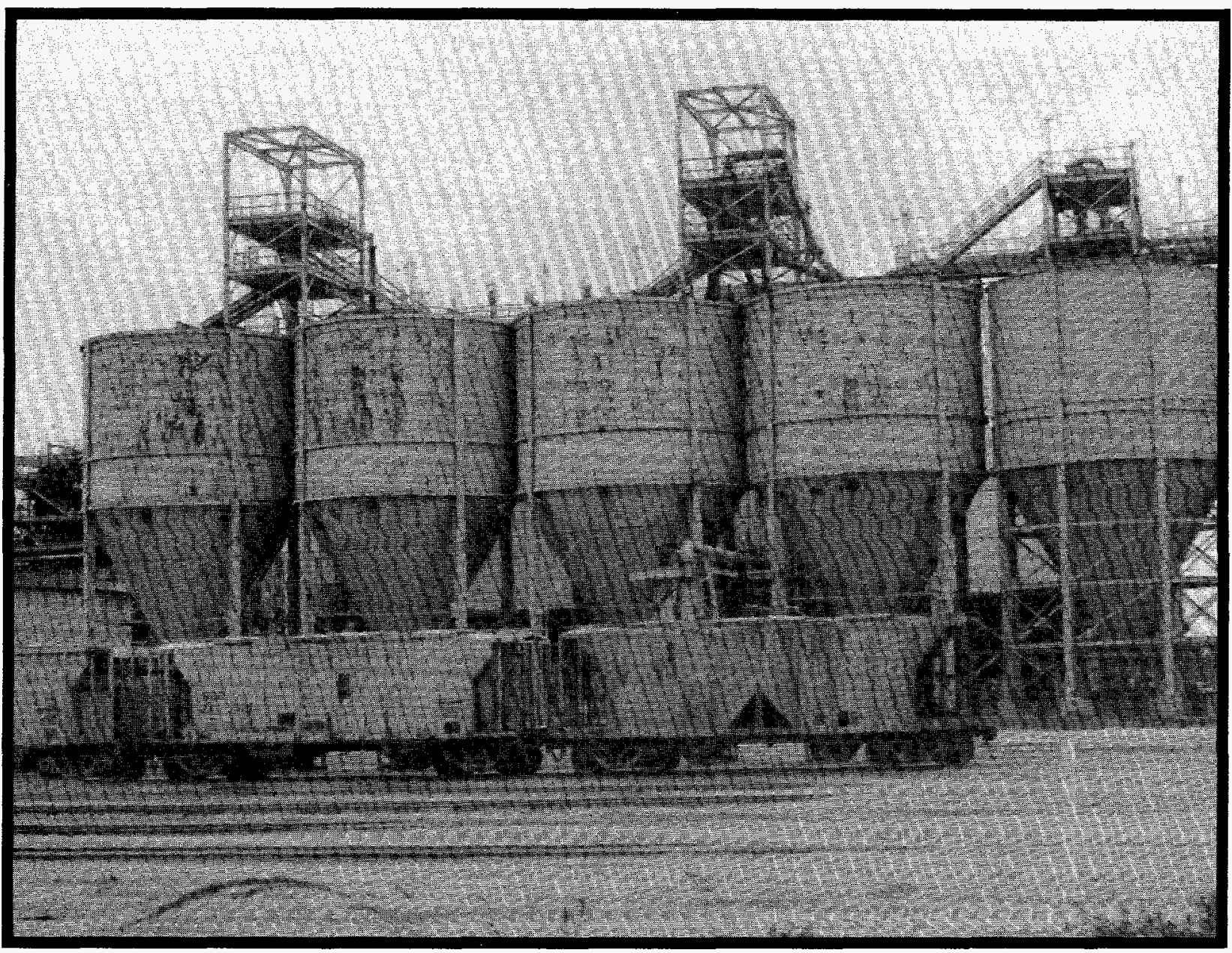

The Freeport Phosphate plant located in Uncle Sam, Louisiana is still active. 



\section{Appendix G}

\section{Uncertainties in the U.S. Uranium Market}

Extensive civilian and military uranium inventories in the East contribute to the uncertainty of the future outlook for the United States and world uranium markets in two respects. The first uncertainty factor is the antidumping petition with respect to uranium exports to the United States from Russia and the other Former Soviet Union (FSU) republics, the resulting suspension agreements, and the amendment to the Russian suspension agreement. The second factor is the agreement with Russia for the U.S. to purchase 500 metric tons of Russia's highly enriched uranium (HEU) that will be converted to low enriched uranium for use in commercial nuclear reactors.

\section{Antidumping Petition}

Because of increasing U.S. imports of uranium from the Soviet Union since 1989, a coalition of 13 domestic uranium producers, and the Oil, Chemical and Atomic Workers Union filed an antidumping petition with the International Trade Administration of the U.S. Department of Commerce (DOC) and the U.S. International Trade Commission (ITC) in November 1991. The petitioners alleged that large volumes of natural and enriched Soviet uranium were exported at less than fair value prices, causing past injury and threatening further injury to the domestic uranium industry. ${ }^{127}$

The first decision in the administrative process was the DOC's initiation of the investigation; then the case moved to the ITC. After receiving relevant materials from both sides and conducting a conference on the issue, the ITC made a preliminary decision in December 1991 that the domestic industry had been injured by reason of the Soviet imports. The case returned to the DOC for investigation and a preliminary determination in the proceedings. ${ }^{128,129}$

In May 1992, the DOC made its preliminary determination that uranium ores and concentrates, enriched uranium product, and uranium hexafluoride $\left(\mathrm{UF}_{6}\right)$ from the six former Soviet republics of Kazakhstan, the Kyrgyz Republic, Russia, Tajikistan, Ukraine, and Uzbekistan were being sold in the United States at less than fair value. It also issued affirmative determinations of "critical circumstances" for the six republics in that imports of uranium were "massive" since the filing of the petition and were also found to be dumped. The DOC's preliminary determination provided that the dumping margin of 115.82 percent did not apply to imports of HEU but did apply to re-exported uranium. The duty applied to all material imported from the six republics since March 5, 1992. ${ }^{130,131}$

The DOC announced that uranium exported from the remaining republics of the FSU was not being sold in the United States at less than fair value after those nations indicated to the DOC that they do not produce, export, or stockpile uranium. ${ }^{132}$

\section{Initial Suspension Agreements}

In October 1992, the DOC announced that it had signed quantitative restraint agreements with the six FSU

\footnotetext{
${ }^{127}$ Volume 1, Petition for the imposition of antidumping duties pursuant to sections 731 and 732 of the Tariff Act of 1930, as amended, on behalf of the Ad Hoc Committee of Domestic Uranium Producers and on behalf of the Oil, Chemical and Atomic Workers International Union, in the matter of uranium from the Union of Soviet Socialist Republics (November 8, 1991).

${ }^{128}$ Nuexco Monthly Report, "International Trade Commission Public Conference" (Denver, CO, December 1991 ), p. 13.

${ }^{129}$ NuclearFuel, "Antidumping Case Likely to Continue Despite Opposition at 'Conference'," December 9, 1991, pp. 1, 12-14.

${ }^{130}$ U.S. Department of Commerce, "Preliminary Determinations: Uranium Dumped from Six Newly Independent States of the Former Soviet Union; Other Six Found Not Dumping," Press Release ITA 92-31, May 29, 1992, 2 p. plus 4-page fact sheet.

${ }^{131}$ Federal Register, "Preliminary Determinations of Sales at Less Than Fair Value: Uranium from Kazakhstan, Kyrgyzstan, Russia, Tajikistan, Ukraine and Uzbekistan; and Preliminary Determinations of Sales at Less Than Fair Value: Uranium from Armenia, Azerbaijan, Belarus, Georgia, Moldova and Turkmenistan," Vol. 57, No. 107 (June 3, 1992), pp. 23380-23384.

${ }^{132}$ Nuexco Monthly Report, Brief Summary of May 29, 1992 DOC Preliminary Determinations (Denver, CO, June 1992$)$, pp. $14-15$.
} 
republics that were cited in the preliminary determination. The agreements placed quotas on the annual amounts of their uranium imports into the United States during the next 10 years, tied to the U.S. domestic market price of uranium. Specified long-term uranium import contracts made by U.S. utilities before March 5, 1992, were grandfathered. The quantitative restraint agreements included additional, separate quotas for Russian exports of HEU to the United States as well as authorizing a one-time sale of low-enriched uranium (LEU) during 1993 and 1994..$^{133,134,135}$

Ukraine and Tajikistan subsequently gave the DOC 60day notices of intent to terminate their suspension agreements, and these terminations were effective in April 1993. ${ }^{136,137}$ Therefore, DOC resumed its antidumping proceeding against the two republics and made final Less Than Fair Value (LTFV) determinations in June 1993. It determined that uranium exports from both republics had been dumped; the final dumping margin was raised to 129.29 percent from the $\mathbf{1 1 5 . 8 2}$ percent in the preliminary determination because of an error detected in labor costs initially calculated for the surrogate countries of Namibia and Great Britain. The DOC also added HEU to the forms of uranium to which the dumping margin was applicable in view of the future expected dilution of HEU from dismantled nuclear weapons to reactor-grade uranium fuel for power plants. The dumping margin would apply to material exported from the two republics on or after March 5, 1992. ${ }^{138}$

The ITC considered further evidence from the petitioners and the two republics at a hearing in July 1993, and received additional information thereafter. It made its final determinations for Tajikistan and Ukraine in August 1993. For Tajikistan, the ITC made a negative final determination and found that the U.S. uranium industry had not been materially injured by uranium imports from Tajikistan because no such imports were reported from January 1990 through March 1993. With regard to Ukraine, the ITC made a negative final determination on imports of highly enriched uranium but an affirmative final determination of injury to the U.S. uranium industry by imports of other forms of uranium from that republic. The ITC sent a written notification of these final determinations to the DOC, which issued its antidumping duty order for Ukrainian uranium imports in August 1993. ${ }^{139,140}$

\section{Russialn Amendment}

The suspension agreement signed by the DOC with Russia, but not those signed with the other FSU republics, provided that the DOC would consider possible adjustmerits to the Russian agreement should the DOC market price on September 30, 1993, be below $\$ 13$ per pound $\mathrm{U}_{3} \mathrm{O}_{8}$. Because that price was $\$ 11.12$ per pound, ${ }^{141}$ the DOC and the Russian Ministry of Atomic Energy (Minatom) subsequently discussed the matter, and in December 1993 the two organizations initialed an amendment to their suspension agreement. The DOC provided information on the ameridment to interested parties for comment. After consideration by the DOC of the comments submitted and further consultations between the two parties, the DOC and the Government of the Russian Federation (GRF) signed the final agreement on March 11, 1994; it was published in the Federa! Register on April 1, 1994. ${ }^{142,143,144}$

${ }^{133}$ U.S. Department of Commerce, "Commerce Signs Suspension Agreements with Six Republics within the Commonwealth of Independent States (CIS)," Press Release ITA 92-73, October 19, 1992, 2 p. plus 3-page fact sheet, l page of quota allocations.

${ }^{134}$ NuclearFuel, "CIS Republics Sign U Suspension Agreements to End Antidumping Case," October 21, 1992, pp. 1-6.

${ }^{135}$ Federal Register, "Antidumping; Uranium from Kazakhstan, Kyrgyzstan, Russia, Tajikistan, Ukraine and Uzbekistan; Suspension of Investigations and Amendment of Preliminary Determinations," Vol. 57, No. 211 (October 30, 1992), pp. $49220-49261$.

${ }^{136}$ Ux Report, DOC's Acceptance of Ukraine's Termination of Its Suspension Agreement, Effective as of April 12, 1993

(April 19, 1993), pp. 2-3.

${ }^{137}$ Ux Report, DOC's Acceptance of Tajikistan's Termination of Its Suspension Agreement, Effective as of April 25, 1993 (May 17, 1993), p. 2.

${ }^{138}$ Federal Register, "Final Determination of Sales at Less Than Fair Value: Uranium from Ukraine and Tajikistan," Vol. 58, No. 129 (July 8, 1993), pp. 36640-36653.

${ }^{139}$ U.S. International Trade Commission, "Uranium from Tajikistan Does Not Injure U.S. Industry, but Uranium from Ukraine Does, Says ITC," Press Release OPA 93-080 (August 6, 1993), pp. 1-4.

${ }^{140}$ Federal Register, "Antidumping Duty Order: Uranium from Ukraine; Termination of Investigation: Uranium from Tajikistan," Vol. 58, No. 166 (August 30, 1993), pp. 45483-45484.

${ }^{141}$ NuclearFuel, "DOC Announces Market Price of $\$ 11.12 / \mathrm{lb}$ " (October 11, 1993), p. 13.

${ }^{142}$ NuclearFuel, "Amendment to the Agreement Suspending Antidumping Investigation on Uranium from the Russian Federation" (January 3, 1994), pp. 13-15. 7.

${ }^{143}$ NuclearFuel, "DOC, Minatom Sign Amended Agreement Providing for 'Matched' U/SWU Sales" (March 15, 1994 Special Issue), pp. 1-

${ }^{144}$ Federal Register, "Amendment to the Agreement Suspending the Antidumping Investigation on Uranium from the Russian Fiederation," Vol. 59, No. 63 (April 1, 1994), pp. 15373-15377. 
The amendment extends the agreement until March 31, 2004, and revises Sections II, IV, VIII, and XIV. Appendix $\mathrm{A}$ of the agreement (that placed quotas on the annual amounts of uranium imported into the United States) is suspended until March 31, 2004. All other provisions of the agreement, particularly section VII, remain in force and apply to this amendment. ${ }^{145}$ (Section VII of the original agreement contained provisions relating to anticircumvention.)

Between April 1, 1994, and March 31, 2004, the amendment provides for matched sales of Russian-origin natural uranium or SWU with newly produced U.S.origin natural uranium or SWU. It authorizes annual matched sales in the first 2 years of up to 3,000 metric tons $\left(6,613,860\right.$ pounds $\mathrm{U}_{3} \mathrm{O}_{8}$ equivalent) per year of Russian-origin natural uranium and up to 2 million Russian-origin SWU per year from the Russian Federation to the United States. The matching natural uranium or SWU must be sold during 1994 and 1995 but may be imported for delivery at any time during the life of the amendment. For 1996 through 2003, the amendment authorizes additional matching deliveries of natural uranium up to, but not exceeding, the levels listed in attachment 1 (as shown in Table G1). Except for the second year, these sales involve equal quantities of Russian and U.S. products. Spot contracts must be matched to spot contracts and long-term contracts to long-term contracts and uranium type to uranium type (i.e., $\mathrm{U}_{3} \mathrm{O}_{8}$ or $\mathrm{UF}_{6}$ ).

Section II of the amendment now includes definitions for "U.S. producer" and "newly produced natural uranium." It also states that if Minatom has not concluded sales of at least 2,204,620 pounds $\mathrm{U}_{3} \mathrm{O}_{8}$ equivalent during the first 6 months of this amendment, up to $1,000,000$ pounds $\mathrm{U}_{3} \mathrm{O}_{8}$ equivalent mined prior, and milled subsequent to, the effective date of this amendment, may be used for the purpose of matched sales for the remainder of that year.

The new subsections of Section IV contain extensive information on the procedures for making matched sales contracts, what types of U.S. and Russian materials qualify for such contracts, per company limits for matched imports, and the manner in which the DOC will confirm matched contracts. Russian origin means natural uranium or SWU which is produced in Russia, and which is exported from Russia for the first time after the effective date of the amendment. U.S.origin natural uranium must be mined in the United
Table G1. Annual Russian-Origin Uranium Sales Authorized by the Amendment, 1994-2003

\begin{tabular}{|c|c|c|c|}
\hline & Year & $\begin{array}{l}\text { Natural Uranium } \\
\text { (Thousand } \\
\text { pounds } \mathrm{U}_{3} \mathrm{O}_{8} \text { ) }\end{array}$ & $\begin{array}{c}\text { Thousand } \\
\text { SWUs }^{\mathrm{a}}\end{array}$ \\
\hline 1994 & $\ldots \ldots \ldots$ & 6,614 & 2,000 \\
\hline 1995 & $\ldots \ldots \ldots$ & 6,614 & 2,000 \\
\hline 1996 & $\ldots \ldots \ldots$ & 1,930 & $\mathrm{n} / \mathrm{a}$ \\
\hline 1997 & $\ldots \ldots \ldots$ & 2,710 & $\mathrm{n} / \mathrm{a}$ \\
\hline 1998 & $\ldots \ldots \ldots$ & 3,600 & $\mathrm{n} / \mathrm{a}$ \\
\hline 1999 & $\ldots \ldots \ldots$ & 4,040 & $n / a$ \\
\hline 2000 & $\ldots \ldots \ldots \ldots$ & 4,230 & $\mathrm{n} / \mathrm{a}$ \\
\hline 2001 & $\ldots \ldots \ldots$ & 4,040 & $\mathrm{n} / \mathrm{a}$ \\
\hline 2002 & $\ldots \ldots \ldots$ & 4,890 & $\mathrm{n} / \mathrm{a}$ \\
\hline 2003 & $\ldots \ldots \ldots$ & 4,300 & $\mathrm{n} / \mathrm{a}$ \\
\hline
\end{tabular}

${ }^{a}$ SWUs-Separative Work Units.

Note: The quota volumes in 1994 and 1995 apply to sales. Deliveries pursuant to these contracts may be delivered in subsequent years.

Source: Attachment 1 to the Federal Register notice of April 1 , 1994.

States, and /or the U.S.-produced SWU must be or have been performed in the United States after the effective date of this amendment and must be delivered to meet the needs of end users that are uncommitted as of March 11, 1994. The market will set the matched contract prices, rather than the DOC, and the U.S. producer's price must be higher than Russia's if the producer is not the direct seller.

Section VIII of the initial agreement relates to the provisions for the DOC's implementation of and Russian compliance with the agreement. The amendment contains an addendum to Section VIII whereby Minatom will provide specified data to the DOC for informational purposes and for verification.

A new "miscellaneous" subsection in Section XIV provides for regular consultations between the parties during the term of this agreement on Russia's being treated as a market economy or the Russian uranium industry's being treated as a market-oriented industry under U.S. antidumping laws. Russia is to be treated as favorably as any other FSU republic that also has a suspension agreement with the United States with respect to uranium. Should this situation change in the future, the parties will promptly enter into consultations with a view to amend the agreement so as to eliminate such less favorable treatment. ${ }^{146}$

\footnotetext{
${ }^{145}$ Federal Register, "Amendment to the Agreement Suspending the Antidumping Investigation on Uranium from the Russian Federation," Vol. 59, No. 63 (April 1, 1994), pp. 15373-15377.

${ }^{146}$ Federal Register, "Amendment to the Agreement Suspending the Antidumping Investigation on Uranium from the Russian Federation," Vol. 59, No. 63 (April 1, 1994), pp. 15373-15377.
} 
After the amended agreement was signed between the governments of the United States and Russia, the governments of Canada, Australia, and Namibia sent protests to the U.S. Government alleging that the amendment to the Russian suspension agreement violates the provisions of the North American Free Trade Agreement (NAFTA) and the General Agreement on Tariffs and Trade (GATT). Canadian and U.S. officials have already held discussions on this issue, and additional discussions are likely. To date, there has been no further action from Australian representatives with the U.S. government. A letter dated April 14, 1994, from the Namibian Ambassador to the Commerce Secretary requested that the $\mathrm{DOC}$ monitor the participation in matched sales to ensure that circumvention does not occur. He also asked that the suspension agreements currently in place with three other FSU republics remain unchanged, so that Namibia and other U.S. trade partners compete on a long established regime based on free and fair trade. ${ }^{147}$

Meanwhile, the DOC held discussions with the FSU republics of Uzbekistan and Kazakhstan on the possible amendment of their suspension agreements. The terms of such amendments have not been finalized, but they could result in revision of the agreement with the GRF. ${ }^{148}$

The Antitrust Division of the U.S. Department of Justice informed the DOC on March 10, 1994, about potential conflicts between the amended Russian suspension agreement and United States antitrust law. The DOC, however, maintains that the pact is legally sound. In conjunction with the amended agreement, firms involved in the uranium market have visited DOC officials to seek details on how the suspension agreement would be implemented. A DOC official stated that several matched sales contracts are pending, and the DOC expected to issue a fact sheet to clarify the procedure for making matched sales. ${ }^{149}$ Such a fact sheet was issued on June 17, 1994.

The petitioners that had brought the initial complaint to the DOC in November 1991 filed suit on June 1, 1994, with the U.S. Court of International Trade to overturn the amended Russian uranium suspension agreement.
They asked the Court to order the DOC to resume the LTFV investigation that could lead to the imposition of high duties on all imports of Russian uranium. ${ }^{150}$ The Court is expected to reach a decision on the case in about a year. It is uncertain how the court case will influence the development and the DOC's approval of matched sales between Russian and U.S. producers and utilities. ${ }^{151}$ Canadian officials expected to meet again with the DOC to continue discussions about the amended Russian suspension agreement and the Canadian belief that it violates NAFTA provisions. ${ }^{152}$

\section{HEU Agreement}

The end of the Cold War allowed the United States and the successor states of the FSU to engage in arms reductions on a large scale, because the fissile materials from the clismantled nuclear weapons, highly enriched uranium (HEU) and plutonium, are no longer needed for military purposes. The HEU from such weapons can be blended down to commercial nuclear fuel for use in civilian reactors.

In August 1992, the U.S. and Russian governments initialed an agreement for the U.S. Department of Energy's purchase of HEU from dismantled FSU nuclear weapons. The agreement did not specify an exact amount of HEU, but Russian officials said that the quantity would be on the order of 500 metric tons uranium. ${ }^{153}$ In February 1993, the United States and Russia signed a clarification and revision of the initial agreement: which specifies that the HEU is to be blended down to low-enriched uranium (LEU) in Russia. ${ }^{154}$ This framework agreement states that the United States shall use the LEU converted from HEU in such a manner so as to minimize disruptions in the market and maximize the overall economic benefit for both parties. It also provided an agreement to go into effect by September 1993 that would establish the terms for such HEU purchases and the dilution of that material to LEU for sale as commercial nuclear fuel. However, the head of the Russian Ministry of Atomic Energy (Minatom) linked the signing of: a final agreement with the United States on the HEU sales to

\footnotetext{
${ }^{147} U x$ Report, "Antidumping Updates - Legal Challenges to Russian Amendment:" (April 25, 1994), pp. 2-3.

${ }^{148} U x$ Report, "Antidumping Talks Behind Closed Doors" (May 9, 1994), p. 3.

${ }^{149}$ NuclearFuel, "Antitrust Worries Swirl Around Antidumping Suspension Agreement" (June 6, 1994), pp. 2-3.

${ }^{150}$ NuclearFuel, "Producers/Union Sue to Overturn Russian Pact" (June 6, 1994), p. 18.

${ }^{151}$ Ux Report, "Antidumping/Amendment Update" (June 13, 1994), p. 2.

${ }^{152}$ NuclearFuel, "USTR Says It Can't Provide Answers" (June 20, 1994), pp. 20-21.

${ }^{153}$ NuclearFuel, "U.S. Agrees to Buy Russian HEU, But Details Must Be Worked Out" (September 2, 1992 Special Issue), pp. 1-3.

${ }^{154}$ NuclearFuel, "U.S.-Russian Agreement on HEU Deal Clears Way for Contract Talks" (March 1, 1993), pp. 2-5.
} 
the resolution of the antidumping case against the FSU. ${ }^{155,156}$

Russian and U.S. officials signed a contract on January 14, 1994, whereby the U.S. Enrichment Corporation (USEC) will pay for the transfer to the United States of LEU blended down from HEU in dismantled Russian nuclear weapons. The HEU agreement is for 20 years and calls for the United States to pay about $\$ 11.9$ billion (unadjusted 1993 dollars) to Russia in exchange for at least 500 metric tons HEU that will be converted with 1.5 percent $U_{235}$ to produce $L E U$ of 4.4 percent $U_{235}$. The 15,259 metric tons of LEU would equate to about 398 million pounds $\mathrm{U}_{3} \mathrm{O}_{8}$ and 92 million separative work units, or SWU (assumed enrichment tails assay of 0.30 percent $U_{235}$ ). The blendstock contributes 113 million pounds to the total LEU obtained from the HEU. Another 50 metric tons of HEU in Ukrainian nuclear weapons also will be part of the purchase agreement. ${ }^{157,158}$

For the first 5 years of the agreement the USEC is to make annual purchases of 10 metric tons HEU, equivalent to about 310 metric tons LEU, and for the remaining 15 years it is to make annual purchases of 30 metric tons HEU, equivalent to about 930 metric tons LEU. Ten metric tons HEU blended down to LEU of 4.4 percent $U_{235}$ at a tails assay of 0.30 percent contains about 1.9 million SWUs and 8 million pounds $\mathrm{U}_{3} \mathrm{O}_{8}$ equivalent.

Under the agreement the enrichment and natural $\mathrm{UF}_{6}$ components of the LEU are priced for fiscal year 1994. at $\$ 780$ per kilogram uranium $(\mathrm{kgU})$. "For the purpose of pricing each delivery order, one (1) $\mathrm{kgU}$ of LEU consists of 6.0386 SWUs at $\$ 82.10$ per SWU and 9.9757 kgUs of natural uranium at $\$ 28.50$ per kgU." The pricing agreement further states that "The total dollar amount of the LEU having an assay of 4.4 percent in the isotope $U_{235}$ for each delivery order shall be adjusted for U.S. inflation and changes in international market conditions during the annual review, with respect to prices for orders placed the following year."

The USEC initially expected to receive its first LEU delivery under the agreement at St. Petersburg, Russia, in June 1994, but that delivery was delayed due to difficulties in resolving the transparency ${ }^{159}$ issue. Within 60 days of that delivery the USEC will pay Russia for the SWU's contained in the shipment. However, it will pay for the uranium feed component of the material when it sells the uranium or uses it to overfeed the USEC's leased enrichment plants. ${ }^{160}$

On March 18, 1994, the DOE and Minatom signed a protocol to assure the proper handling of HEU from FSU weapons that is to be diluted for use as commercial reactor fuel and sold to the United States. The two organizations still must agree on the technical specifications for the blended-down HEU, and the American Society for Testing and Materials plans to develop such specifications. ${ }^{161,162}$ The protocol followed the Memorandum of Understanding (MOU) that was signed by the United States and Russia on September 1, 1993. It authorizes each side to monitor certain activities carried out at specified facilities as well as any other facility at which operations subject to the MOU and protocol are performed.

June 7, 1994, six Russian enterprises and two U.S. companies announced the formation of Matek, a joint venture that is planned to help implement the U.S.Russian HEU sales. Nuclear Fuel Services Inc. and Allied-Signal, the two U.S. firms, will have 20 percent of the equity. The Russian partners are the Ural Electrochemical Integrated Plant, Techsnabexport, the Siberian Chemical Plant, the Priargunski Mining-Chemical Plant, the Russian Academy of Sciences, and the trade company Litintern; they will hold 80 percent of the equity.

Concurrent with this development, Russian Minister of Atomic Energy Viktor Mikhailov proposed, in a letter of June 6 to Vice President Albert Gore, that Minatom ship 30 metric tons of HEU as $\mathrm{UF}_{6}$ or $\mathrm{UO}_{2}$ to the United States; this HEU was derived from dismantled Ukrainian nuclear weapons. The material would be blended down to commercial reactor fuel under the auspices of Matek. Mr. Mikhailov's offer to export both HEU and LEU apparently is an effort to speed up the flow of funds to Minatom under the HEU program. Such HEU shipments would require the issuance of U.S.

\footnotetext{
${ }^{155}$ NuclearFuel, "Mikhailov Links CIS-U.S. HEU Pact to End of U Antidumping Case" (September 14, 1992), pp. 1-2.

${ }^{156}$ NuclearFuel, "Russia Won't Sign HEU Contract Unless Antidumping Case Is Resolved" (September 13, 1993 ), pp. 1, $10-11$.

${ }^{157}$ Energy Resources International, Inc., "1993 Nuclear Fuel Cycle Supply and Price Report - Update" (Washington, DC, November 1993), pp. 4-6 - 4-8, 6-4 - 6-7.

${ }^{158}$ NuclearFuel, "HEU Deal Signed in Moscow by Timbers, Mikhailov; Terms Unchanged" (January 17, 1994 Special Issue), pp. 1-2.

${ }^{159}$ Transparency refers to both governments being assured that the uranium came from weapons and is being used properly in the United States.

${ }^{160}$ NuclearFuel, "Transparency Agreement Difficulties Slow Transfer of Russian HEU to U.S." (March 14, 1994), p. 6.

${ }^{161}$ NuclearFuel, "Transparency Accord Removes a Bar to Transfer of Russian HEU to USEC" (March 28, 1994), pp. 6-8.

${ }^{162}$ NuclearFuel, "ASTM to Develop New Standard for Blended-down HEU from Weapons" (March 28, 1994), p. 8.
} 
Government credits or financing by commercial U.S. banks. Mr. Mikhailov reportedly met with executives of the Citicorp, Chase Manhattan, and Morgan Guaranty banks during an earlier visit to the United States.

The Russian partners in Matek favor HEU blending in the United States because Russian facilities for such work currently lack sufficient capacity to handle all the blending needed for processing the HEU from dismantled weapons in the FSU. Matek is chartered to process and sell HEU from the four republics of Kazakhstan, Belarus, Ukraine, and Russia; it could also blend down U.S. weapons' HEU should the U.S. Government authorize this work. ${ }^{163}$

In late June 1994, Russian Prime Minister Viktor Chernomyrdin met with Vice President Gore to discuss the adverse effect on the Russian HEU sales to the United States of the petitioners' lawsuit against the Russian suspension agreement in the U.S. Court of International Trade. ${ }^{164}$ The president of Techsnabexport insisted that the lawsuit make renegotiation of the HEU agreement necessary because of the linkage between the two issues; he also attended the meetings in Washington, DC, between U.S. and Russian officials. ${ }^{165}$

The impact on the market of uranium supplies from the HEU agreement is uncertain. According to the terms of the agreement, 10 metric tons of Russian HEU will be available annually for conversion to LEU in the first 5 years. On an equivalent basis, this will augment available uranium supplies by about 8 million pounds $\mathrm{U}_{3} \mathrm{O}_{8}$, which is a considerable addition. In the subsequent 15 years, uranium from $\mathrm{HEU}$ would be equivalent to about 24 million pounds $\mathrm{U}_{3} \mathrm{O}_{8}$ annually. It is likely that the absorption of uranium from HEU will impact the uranium markets for a considerable length of time and will continue the current market oversupply into the future.

In June 1994, DOE released information on its highly enriched uranium program. Between 1945 and 1992 (the year HEU production ceased), cumulative HEU production in the United States was 994 metric tons; of this, about 259 metric tons is currently in DOE inventories. ${ }^{166,167}$

\footnotetext{
${ }^{163}$ NuclearFuel, "Matek Teams Russian, U.S. Entities to Implement HEU Deal, Courts USEC" (June 20, 1994), pp. 1-3.

${ }^{164}$ NuclearFuel, "Petitioners Sound Conciliatory Note" (June 20, 1994), p. 20.

${ }^{165}$ Ux Report, "Russians Will Link Antidumping to HEU Deal" (June 20, 1994), p. 2.

${ }^{166}$ NuclearFuel, "258.8 Metric Tons of HEU Now Stored at 12 Sites Around the U.S., DOE Says" (July 4, 1994 ), pp. 1-3.

${ }^{167}$ The current inventory level excludes HEU stored at the Pantex facility in Texas.
} 
Appendix $\mathrm{H}$

U.S. Customary Units of Measurement, International System of Units (SI), and Selected Data Tables and SI Metric Units

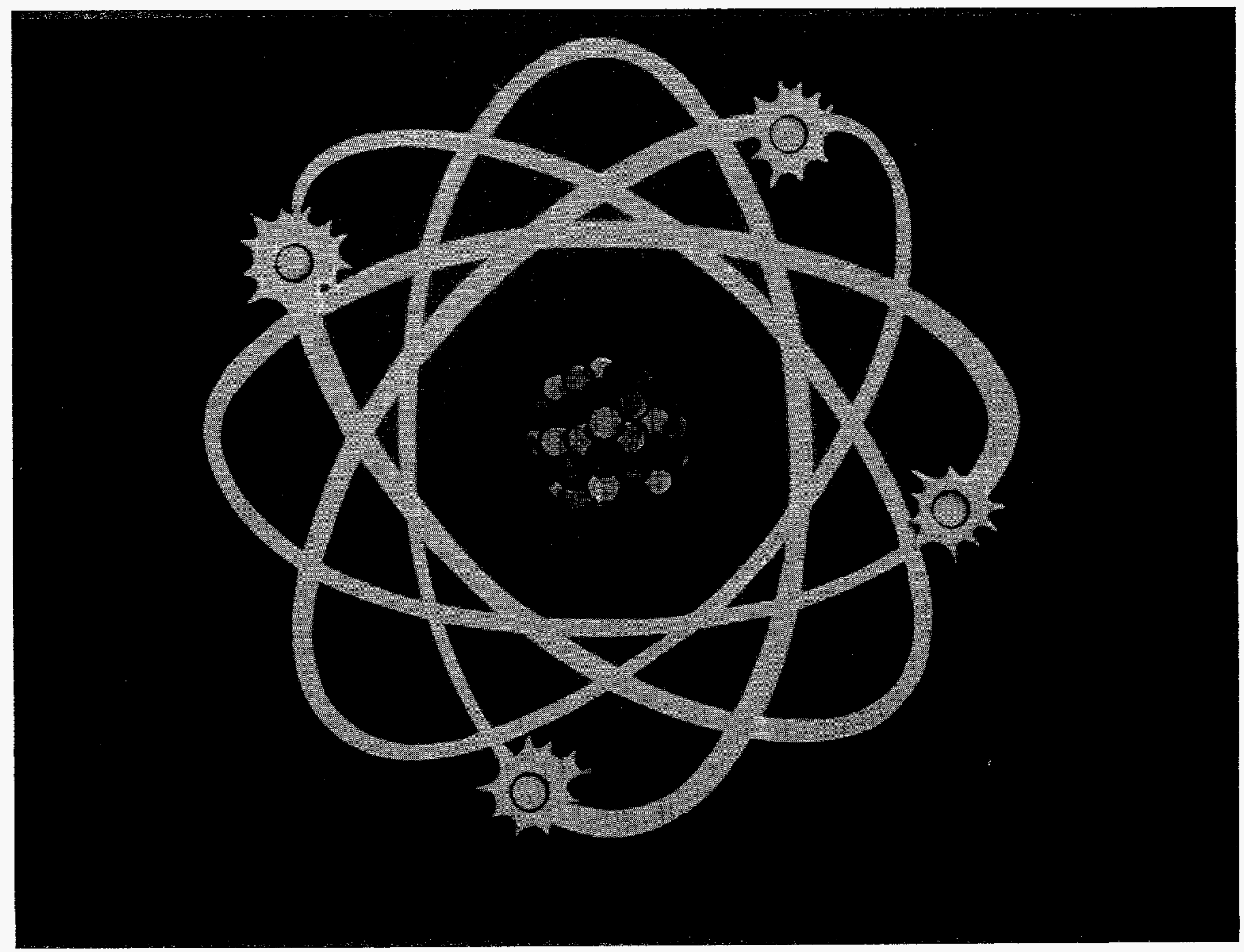





\section{Appendix H}

\section{U.S. Customary Units of Measurement, International System of Units (SI), and Selected Data Tables in SI Metric Units}

Standard factors for interconversion between U.S. customary units and the International System of Units (SI) are shown in the table below. These factors are provided as a coherent and consistent set of units for the convenience of the reader in making conversions between U.S. and metric units of measure for data published in this report. Conversion factors are pro- vided only for the U.S. units of measurement quoted in this report. These forward cost category approximate equivalents are also needed for some conversions:

$\$ 30$ per pound $\mathrm{U}_{3} \mathrm{O}_{8}=\$ 80$ per kilogram $\mathrm{U}$.

$\$ 50$ per pound $\mathrm{U}_{3} \mathrm{O}_{8}=\$ 130$ per kilogram $\mathrm{U}$.

Conversion Factors for U.S. Customary Units and SI Metric Units of Measurement

\begin{tabular}{ccc}
\hline To convert from: & To: & Multiply by: \\
\hline feet & meters & 0.304801 \\
short tons & metric tons & 0.907185 \\
pounds $\mathrm{U}_{3} \mathrm{O}_{8}$ & kilogram $\mathrm{C}$ & 0.384647 \\
million pounds $\mathrm{U}_{3} \mathrm{O}_{8}$ & thousand metric tons $\mathrm{U}$ & 0.384647 \\
\hline
\end{tabular}


Table H1. Projected Annual Uranium Requirements for World Nuclear Power Plants, 1994-2010 (Thousand Metric Tons of Uranium)

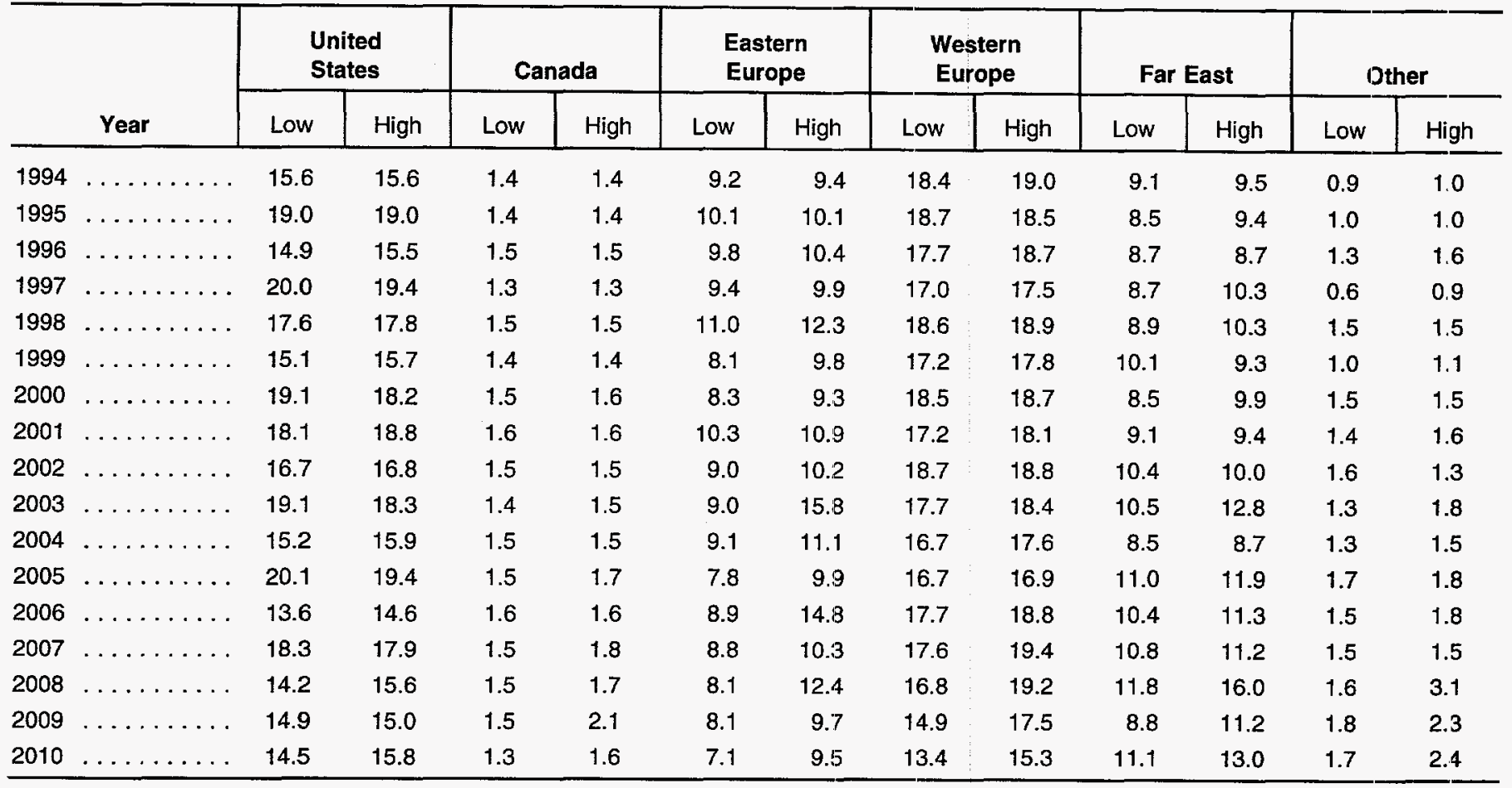

Source: Energy Information Administration, Office of Coal, Nuclear, Electric and Alternate Fuels, International Nuclear Model, File INM94.WK3.

Table H2. Projected Cumulative Uranium Requirements for World Nuclear Power Plants, 1994-2010 (Thousand Metric Tons of Uranium)

\begin{tabular}{|c|c|c|c|c|c|c|c|c|c|c|c|c|c|}
\hline & \multirow[b]{2}{*}{ Year } & \multicolumn{2}{|c|}{$\begin{array}{l}\text { United } \\
\text { States }\end{array}$} & \multicolumn{2}{|c|}{ Canada } & \multicolumn{2}{|c|}{$\begin{array}{l}\text { Eastern } \\
\text { Europe }\end{array}$} & \multicolumn{2}{|c|}{$\begin{array}{c}\text { Western } \\
\text { Europe }\end{array}$} & \multicolumn{2}{|c|}{ Far East } & \multicolumn{2}{|c|}{ Other } \\
\hline & & Low & High & Low & High & Low & Highı & Low & High & Low & High & Low & High \\
\hline 1994 & . & 15.6 & 15.6 & 1.4 & 1.4 & 9.2 & 9.4 & 18.4 & 19.0 & 9.1 & 9.5 & 0.9 & 1.0 \\
\hline 1995 & & 34.6 & 34.6 & 2.8 & 2.8 & 19.3 & 19.5 & 37.1 & 37.5 & 17.6 & 18.8 & 2.0 & 2.0 \\
\hline 1996 & & 49.5 & 50.1 & 4.3 & 4.3 & 29.1 & 29.9 & 54.8 & 56.2 & 26.3 & 27.5 & 3.3 & 3.6 \\
\hline 1999 & & 102.2 & 103.1 & 8.5 & 8.5 & 57.6 & 61.9 & 107.6 & 110.4 & 54.0 & 57.4 & 6.4 & 7.1 \\
\hline 2000 & & 121.3 & 121.3 & 10.1 & 10.1 & 65.9 & 71.2 & 126.1 & 129.2 & 62.6 & 67.3 & 7.9 & 8.6 \\
\hline 2001 & & 139.4 & 140.1 & 11.7 & 11.8 & 76.2 & 82.1 & 143.3 & 147.3 & 71.7 & 76.7 & 9.3 & 10.2 \\
\hline 2002 & & 156.2 & 156.9 & 13.2 & 13.2 & 85.2 & 92.3 & 162.1 & 166.0 & 82.1 & 86.7 & 10.9 & 11.5 \\
\hline 2003 & & 175.3 & 175.2 & 14.6 & 14.7 & 94.2 & 108.1 & 179.8 & 184.4 & 92.6 & 99.6 & 12.2 & 13.3 \\
\hline 2008 & & 256.7 & 258.6 & 22.2 & 23.0 & 136.9 & 166.6 & 26.5 .4 & 276.3 & 144.9 & 158.7 & 19.7 & 23.0 \\
\hline 2009 & & 271.6 & 273.6 & 23.7 & 25.1 & 144.9 & 176.3 & 280.2 & 293.8 & 153.7 & 169.9 & 21.5 & 25.3 \\
\hline 2010 & & 286.1 & 289.5 & 25.1 & 26.6 & 152.0 & 185.8 & $29: 3.6$ & 309.2 & 164.8 & 182.9 & 23.2 & 27.7 \\
\hline
\end{tabular}

Source: Energy Information Administration, Office of Coal, Nuclear, Electric and Alternate Fuels, International Nuclear Model, File: INM94.WK3. 
Table H3. Projected U.S. Spot-Market Prices for

Uranium Under Current Market

Conditions, 1994-2005

(Constant 1993 Dollars per

Kilogram Uranium)

\begin{tabular}{|c|c|c|}
\hline & Year & Prices \\
\hline 1994 & $\ldots \ldots \ldots \ldots \ldots \ldots \ldots \ldots$ & 23.84 \\
\hline 1995 & $\ldots \ldots \ldots \ldots \ldots \ldots \ldots$ & 25.06 \\
\hline 1996 & $\ldots \ldots \ldots \ldots \ldots \ldots \ldots$ & 26.70 \\
\hline 1997 & $\ldots \ldots \ldots \ldots \ldots \ldots \ldots \ldots$ & 27.84 \\
\hline 1998 & $\ldots \ldots \ldots \ldots \ldots \ldots \ldots \ldots$ & 29.09 \\
\hline 1999 & $\ldots \ldots \ldots \ldots \ldots \ldots \ldots \ldots$ & 29.95 \\
\hline 2000 & $\ldots \ldots \ldots \ldots$ & 30.81 \\
\hline 2001 & $\ldots \ldots \ldots \ldots \ldots \ldots \ldots \ldots$ & 31.59 \\
\hline 2002 & $\ldots \ldots \ldots \ldots \ldots \ldots \ldots$ & 32.21 \\
\hline 2003 & $\ldots \ldots \ldots \ldots \ldots \ldots \ldots \ldots$ & 32.99 \\
\hline 2004 & $\ldots \ldots \ldots \ldots \ldots \ldots \ldots$ & 33.56 \\
\hline 2005 & $\ldots \ldots \ldots \ldots \ldots \ldots \ldots \ldots \ldots \ldots$ & 34.47 \\
\hline
\end{tabular}

Source: Energy Information Administration, Uranium Market Model run no. 1994-14S.DAT, September 14, 1994.

Table H4. Projected U.S. Uranium Requirements, Net Imports, Commercial Inventories, and Production of Uranium, 1994-2005

(Thousand Metric Tons Uranium)

\begin{tabular}{|c|c|c|c|c|c|}
\hline 1994 & . . & 17.4 & 13.2 & 38.7 & 1.3 \\
\hline 1996 & $\ldots \ldots \ldots \ldots \ldots$ & 18.0 & 14.0 & 33.5 & 1.7 \\
\hline 1997 & $\ldots \ldots \ldots \ldots$ & 17.5 & 13.9 & 31.6 & 1.7 \\
\hline 2000 & $\ldots \ldots \ldots \ldots \ldots$ & 17.5 & 14.2 & 27.7 & 2.1 \\
\hline 2001 & $\ldots \ldots \ldots \ldots \ldots$ & 18.0 & 14.7 & 26.9 & 2.5 \\
\hline 2002 & $\ldots \ldots \ldots$ & 18.0 & 14.4 & 26.1 & 2.8 \\
\hline 2003 & $\ldots \ldots \ldots \ldots \ldots \ldots \ldots \ldots$ & 17.0 & 13.5 & 25.5 & 2.8 \\
\hline 2004 & $\ldots \ldots \ldots \ldots \ldots \ldots \ldots \ldots$ & 18.1 & 14.7 & 25.0 & 3.0 \\
\hline
\end{tabular}

adjusted by three-point smoothing.

${ }^{b}$ Net imports (total imports less exports).

Source: Requirements-Energy Information Administration, International Nuclear Model, File INM94.WK3. Net Imports, Inventories and Production-Energy Information Administration, Uranium Market Model run no. 1994-15S.DAT, September 14, 1994. 



\section{Glossary}

Baseload Plant: A plant, usually housing highefficiency steam-electric units, which is normally operated to take all or part of the minimum load of a system, and which consequently produces electricity at an essentially constant rate and runs continuously. These units are operated to maximize system mechanical and thermal efficiency and minimize system operating costs.

Boiling-Water Reactor (BWR): A light-water reactor in which water, used as both coolant and moderator, is allowed to boil in the core. The resulting steam can be used directly to drive a turbine.

Breeder Reactor: A reactor that both produces and consumes fissionable fuel, especially one that creates more fuel than it consumes. The new fissionable material is created by a process known as breeding, in which neutrons from fission are captured in fertile materials.

Burnup: A measure of the amount of energy obtained from fuel in a reactor. Typically, burnup is expressed as the amount of energy produced per unit weight of fuel irradiated or "burned." Burnup levels are generally measured in units of megawattdays thermal per metric ton of initial heavy metal (MWDT/MTIHM).

Canadian Deuterium-Uranium Reactor (CANDU): A reactor that uses heavy water or deuterium oxide $\left(\mathrm{D}_{2} \mathrm{O}\right)$, rather than light water $\left(\mathrm{H}_{2} \mathrm{O}\right)$ as the coolant and moderator. Deuterium is an isotope of hydrogen that has a different neutron absorption spectrum from that of ordinary hydrogen. In a deuterium-oxide-moderated reactor, fuel made from natural uranium $(0.71 \mathrm{U}-235)$ can sustain a chain reaction.

Capacity: The load for which a generating unit is rated, either by the user or by the manufacturer. In this report, "capacity" refers to the utility's design electrical rating (see below).

Capacity Factor: The ratio of the electricity produced by a generating unit, for the period of time considered, to the energy that could have been produced at continuous full-power operation during the same period.
Commercial Operation: The phase of reactor operation that begins when power ascension ends and the operating utility formally declares to the NRC that the nuclear power plant is available for the regular production of electricity. This declaration is usually related to the satisfactory completion of qualification tests on critical components of the unit.

Construction Pipeline: The various stages involved in the acquisition of a nuclear reactor by a utility. The events that define these stages are the ordering of a reactor, the licensing process, and the physical construction of the nuclear generating unit. A reactor is said to be "in the pipeline" when the reactor is ordered and "out of the pipeline" when it completes low-power testing and begins operation toward full power. (See Operable).

Criticality: The condition in which a nuclear reactor is just self-sustaining (i.e., the rate at which fissioning remains constant.)

Design Electrical Rating (Capacity), Net: The nominal net electrical output of a nuclear unit, as specified by the utility for the purpose of plant design.

Discharged Fuel: Irradiated fuel removed from a reactor during refueling. (See Spent Nuclear Fuel.)

Enrichment Tails Assay: A measure of the amount of fissile uranium (U-235) remaining in the waste stream from the uranium enrichment process. The natural uranium "feed" that enters the enrichment process generally contains 0.711 percent (by weight) U-235. The "product stream" contains enriched uranium (greater than 0.711 percent U-235) and the "waste" or "tails" stream contains depleted uranium (less than 0.711 percent U-235). At the historical enrichment tails assay of 0.2 percent, the waste stream would contain 0.2 percent U-235. A higher enrichment tails assay requires more uranium feed (thus permitting natural uranium stockpiles to be decreased), while increasing the output of enriched material for the same energy expenditure.

Equilibrium Cycle: An analytical term which refers to fuel cycles that occur after the initial one or two cycles of a reactor's operation. For a given reactor, equilibrium cycles have similar fuel characteristics. 
Fast Breeder Reactor (FBR): A reactor in which the fission chain reaction is sustained primarily by fast neutrons rather than by thermal or intermediate neutrons. Fast reactors require little or no use of a moderator to slow down the neutrons from the speeds at which they are ejected from fissioning nuclei. This type of reactor produces more fissile material than it consumes.

Fertile Material: Material that is not itself fissionable by thermal neutrons but can be converted to fissile material by irradiation. The two principal fertile materials are uranium- 238 and thorium- 232 .

Fissile Material: Material that can be caused to undergo atomic fission when bombarded by neutrons. The most important fissionable materials are uranium-235, plutonium-239, and uranium-233.

Fission: The process whereby an atomic nucleus of appropriate type, after capturing a neutron, splits into (generally) two nuclei of lighter elements, with the release of substantial amounts of energy and two or more neutrons.

Forward Costs: The operating and capital costs (in current dollars) still to be incurred in the production of uranium from estimated reserves; such costs are used in assigning the uranium reserves to cost categories. Forward costs include labor, materials, power and fuel, royalties, payroll and production taxes, insurance, and general and administrative costs. Expenditures prior to reserve estimates-e.g., for property acquisition, exploration, mine development, and mill construction-are excluded from forward cost determinations. Income taxes, profit, and the cost of money are also excluded. Thus, forward costs are neither the full costs of production nor the market price at which the uranium will be sold.

Forward Coverage: Amount of uranium required to assure uninterrupted operation of nuclear power plants.

Full-Power Day: The equivalent of 24 hours of full power operation by a reactor. The number of full power days in a specific cycle is the product of the reactor's capacity factor and the length of the cycle.

Gas-Cooled Fast Breeder Reactor (GCBR): A fast breeder reactor that is cooled by a gas (usually helium) under pressure.

Generation (Electricity): The process of producing electric energy from other forms of energy; also, the amount of electric energy produced, expressed in watthours (Wh).

Gross Generation: The total amount of electric energy produced by the generating units at a generating station or stations, measured at the generator terminals.

Net Generation: Gross generation less the electric energy consumed at the generating station for station use.

Gigawatt-Electric (GWe): One billion watts of electric capacity.

Heavy Water: Water containing a significantly greater proportion of heavy hydrogen (deuterium) atoms to ordinary hydrogen atoms than is found in ordinary (light) water. Heavy water is used as a moderator in some reactors because it slows neutrons effectively and also has a low cross-section for absorption of neutrons.

Heavy-Water-Moderated Reactor: A reactor that uses heavy water as its moderator. Heavy water is an excellent moderator and thus permits the use of inexpensive natural (unenriched) uranium as fuel.

Kilowatt-Electric (kWe): One thousand watts of electric capacity.

Kilowatthour (kWh): One thousand watthours.

Light Water: Ordinary water $\left(\mathrm{H}_{2} \mathrm{O}\right)$, as distinguished from heavy water or deuterium oxide $\left(\mathrm{D}_{2} \mathrm{O}\right)$.

Light-Water Reactor (LWR): A nuclear reactor that uses water as the primary coolant and moderator, with slightly enriched uranium as fuel. There are two types of commercial light-water reactors-the boiling-water reactor (BWR) and the pressurized-water reactor (PWR).

Liquid Metal Fast Breeder Reactor (LMFBR): A nuclear breeder reactor, cooled by molten sodium, in which fission is caused by fast neutrons.

Load Following: Regulation of the power output of electric generators within a prescribed area in response to changes in system frequency, tieline loading, or the relation of these to each other, so as to maintain the scheduled system frequency and/or the established interchange with other areas within predetermined limits. 
Long-Term Contract Price: Delivery price determined when contract is signed; it can be either a fixed price or a base price escalated according to a given formula.

Low-Power Testing: The period of time between a plant's initial fuel loading date and the issuance of its operating (full-power) license. The maximum level of operation during this period is 5 percent of the unit's design electrical rating.

MAGNOX: A gas-cooled power reactor that uses graphite as the moderator and carbon dioxide gas as the coolant.

Megawatt-Electric (MWe): One million watts of electric capacity.

Megawatthour (MWh): One million watthours of electric energy.

Metric Tons of Initial Heavy Metal (MTIHM): The weight of the initial fuel loading (in metric tons) used in an assembly.

Metric Tons Uranium (MTU): A measure of weight equivalent to 2,204.6 pounds of uranium and other fissile and fertile materials that are loaded into an assembly during fabrication of the assembly.

Moderator: A material such as ordinary water, heavy water, or graphite, used in a reactor to slow down high-velocity neutrons, thus increasing the likelihood of further fission.

Net Summer Capability: The steady hourly output which generating equipment is expected to supply to a system load exclusive of auxiliary power as demonstrated by testing at the time of summer peak demand.

Nuclear Power Plant: A single- or multi-unit facility in which heat produced in a reactor by the fissioning of nuclear fuel is used to drive a steam turbine(s).

Nuclear Reactor: An apparatus in which the nuclear fission chain can be initiated, maintained, and controlled so that energy is released at a specific rate. The reactor apparatus includes fissionable material (fuel) such as uranium or plutonium; fertile material; moderating material (unless it is a fast reactor); a heavy-walled pressure vessel; shielding to protect personnel; provision for heat removal; and control elements and instrumentation.

Plutonium (Pu): A heavy, fissionable, radioactive, metallic element (atomic number 94). Plutonium occurs in nature in trace amounts. It can also be produced as a byproduct of the fission reaction in a uranium-fueled nuclear reactor and can be recovered for future use.

Power Ascension: The period of time between a plant's initial fuel loading date and its date of first commercial operation (including the low-power testing period). Plants in the first operating cycle (the time from initial fuel loading to the first refueling), which lasts approximately 2 years, operate at an average capacity factor of about 40 percent.

Pressurized-Water Reactor (PWR): A nuclear reactor in which heat is transferred from the core to a heat exchanger via water kept under high pressure, so that high temperatures can be maintained in the primary system without boiling the water. Steam is generated in a secondary circuit.

Reinserted Fuel: Irradiated fuel that is discharged in one cycle and inserted in the same reactor after sitting in the storage pool for at least one subsequent refueling. In a few cases, fuel discharged from one reactor has been used to fuel a different reactor.

Separative Work Unit (SWU): The standard measure of enrichment services. The effort expended in separating a mass $F$ of feed of assay $x_{F}$ into a mass $P$ of product of assay $x_{P}$ and waste of mass $W$ and assay $x_{W}$ is expressed in terms of the number of separative work units needed, given by the expression $S W U=W V\left(x_{W}\right)$ $+P V\left(x_{P}\right)-F V\left(x_{F}\right)$, where $V(x)$ is the "value function," defined as $V(x)=(1-2 x) \ln [(1-x) / x]$.

Spent Nuclear Fuel: Irradiated fuel that is permanently discharged from a reactor at the end of a fuel cycle. Spent or irradiated fuel is usually discharged from reactors because of chemical, physical, and nuclear changes that make the fuel no longer efficient for the production of heat, rather than because of the complete depletion of fissionable material. Except for possible reprocessing, this fuel must eventually be removed from its temporary storage location at the reactor site and placed in a permanent repository. Spent nuclear fuel is typically measured either in metric tons of heavy metal (i.e., only the heavy metal content of the spent fuel is considered) or in metric tons of initial heavy metal (essentially, the initial mass of the uranium before irradiation). The difference between these two quantities is the weight of the fission products.

Split Tails: Use of one tails assay for transaction of enrichment services and a different tails assay for operation of the enrichment plant. This mode of operations typically increases the use of uranium, 
which is relatively inexpensive, while decreasing the use of separative work, which is expensive.

Spot Market: The buying and selling of uranium for immediate or very near-term delivery, typically involving transactions for delivery of up to 500,000 pounds $\mathrm{U}_{3} \mathrm{O}_{8}$ within a year of contract execution.

Spot-Market Price: Price for material being bought and sold on the spot market.

Terawatthour (TWh): One trillion $\left(10^{12}\right)$ watthours of electric energy:

Unfilled Requirements: Requirements not covered by usage of inventory or supply contracts in existence as of January 1 of the survey year.

Uranium (U): A heavy, naturally radioactive, metallic element of atomic number 92. Its two principally occurring isotopes are uranium-235 and uranium-238. Uranium-235 is indispensable to the nuclear industry because it is the only isotope existing in nature to any appreciable extent that is fissionable by thermal neutrons. Uranium-238 is also important, because it absorbs neutrons to produce a radioactive isotope that subsequently decays to plutonium-239, an isotope that also is fissionable by thermal neutrons.

- Concentrate: A yellow or brown powder produced from naturally occurring uranium minerals as a result of milling uranium ores or processing of uranium-bearing solutions. Synonymous with "yellowcake," $\mathrm{U}_{3} \mathrm{O}_{8}$, or uranium oxide.

- Natural Uranium: Uranium with the U-235 isotope present at a concentration of 0.711 percent (by weight), that is, uranium with its isotopic content exactly as it is found in nature.

- Uranium Hexafluoride $\left(\mathrm{UF}_{6}\right)$ : $A$ white solid obtained by chemical treatment of $\mathrm{U}_{3} \mathrm{O}_{8}$, which forms a vapor at temperatures above 56 degrees centigrade. $\mathrm{UF}_{6}$ is the form of uranium required for the enrichment process.

- Uranium Oxide: A compound $\left(\mathrm{U}_{3} \mathrm{O}_{8}\right)$ of uranium. Also referred to as "yellowcake" or concentrate when in pure form.

- Enriched Uranium: Uranium enriched in the isotope U-235, from 0.711 percent (by weight) in natural uranium to an average of 3.0 to 3.5 percent U-235. Low-enriched uranium (LEU) contains up to 19 percent U-235, whereas highly enriched uranium
(HEU) contains at least 20 percent U-235 and over 90 percent if used for nuclear weapons.

- Fabricated Fuel: Fuel assemblies composed of an array of fuel rods loaded with uranium dicxide pellets, manufactured after conversion of enriched uranium hexafluoride to uranium dioxide.

Uranium Resource Categories: Three classes of uranium resources reflecting different levels of confidence in the categories reported. These classes are reasonable assured resources (RAR), estimated additional resources (EAR), and speculative resources (SR). They are described below:

- Uranium Reserves: Estimated quantities of uranium in known mineral deposits of such size, grade, and configuration that the uraniurn could be recovered at or below a specified production cost with currently proven mining and processing technology and under current laws and regulations. Reserves are based on direct radiometric and chemical measurements of drill hole and other types of sampling of the deposits. Mineral grades and thickness, spatial relationships, depths below the surface, mining and reclamation methods, distances to milling facilities, and amenability of ores to processing are considered in the evaluation. The amount of uranium in ore that could be exploited within the forward cost levels are estimated according to conventional enginee:ing practices, utilizing available engineering, geologic, and economic data.

- Reasonably Assured Resources (RAR): The uranium that occurs in known mineral deposits of such size, grade, and configuration that it could be recovered within the given production cost ranges, with currently proven mining and processing technology. Estimates of tonnage and grade are based on specific sample data and measurements of the deposits and on knowledge of deposit characteristics. RAR correspond to DOE's Reserves category.

- Estimated Additional Resources (EAR): The uranium in addition to RAR that is expected to occur, mostly on the basis of direct geological evidence, in extensions of well-explored deposits, little explored deposits, and undiscovered deposits believed to exist along a well-defined geologic trend with known deposits, such that the uranium can subsequently be recovered within the given cost ranges. Estimates of tonnage and grade are based on available sampling data and on knowledge of the deposit characteristics as determined in the best 
known parts of the deposit or in similar deposits. EAR correspond to DOE's Probable Potential Resource Category.

- Speculative Resources (SR): Uranium in addition to EAR that is thought to exist, mostly on the basis of indirect evidence and geological extrapolations, in deposits discoverable with existing exploration techniques. The locations of deposits in this category can generally be specified only as being somewhere within given regions or geological trends. As the term implies, the existence and size of such deposits are speculative. The estimates in this category are less reliable than estimates of EAR. SR corresponds to DOE's Possible Potential Resources plus Speculative Potential Resources categories. 